ГОРНЫЙ ИНСТИТУТ

ФЕДЕРАЛЬНОГО ИССЛЕДОВАТЕЛЬСКОГО ЦЕНТРА

«КОЛЬСКИЙ НАУЧНЫЙ ЦЕНТР РОССИЙСКОЙ АКАДЕМИИ НАУК»

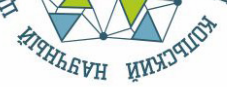

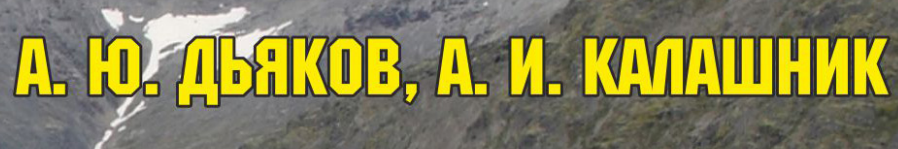 MEIOAYUERKVE OGHOBG

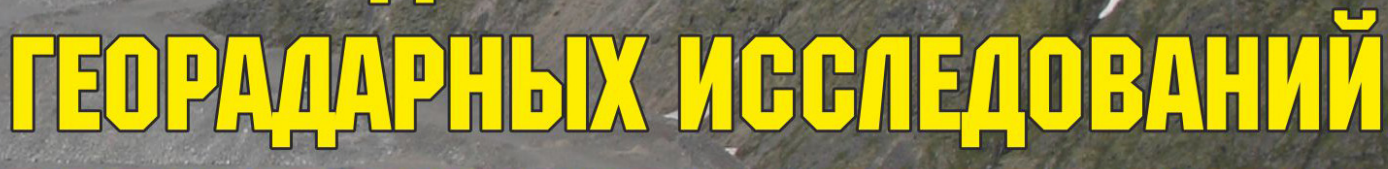

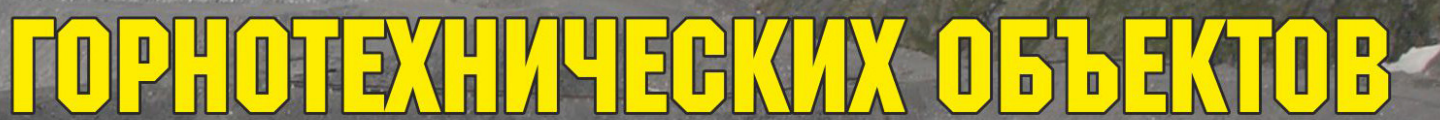

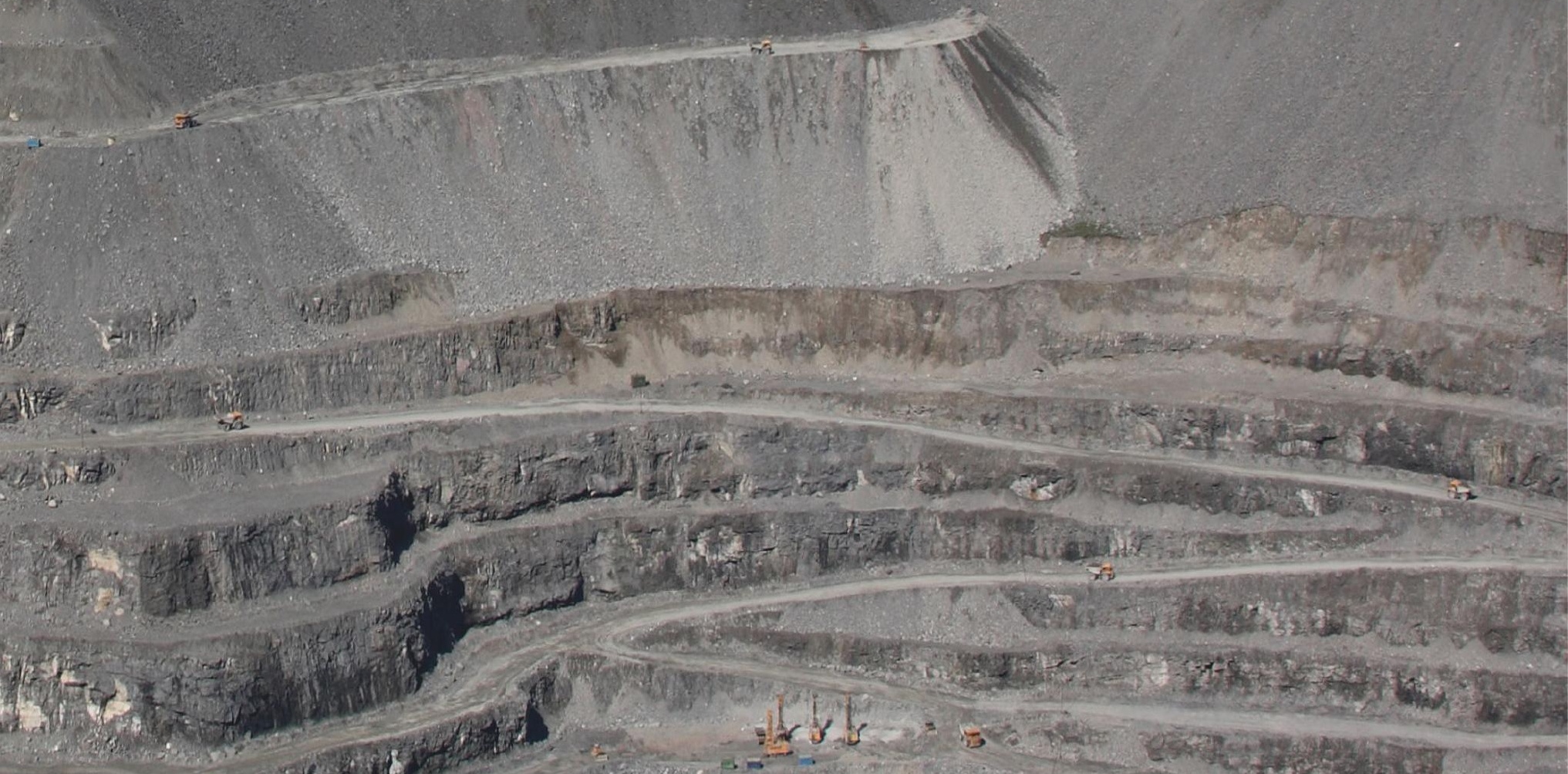


МИНИСТЕРСТВО НАУКИ И ВЫСШЕГО ОБРАЗОВАНИЯ РОССИЙСКОЙ ФЕДЕРАЦИИ

ФЕДЕРАЛЬНЫЙ ИССЛЕДОВАТЕЛЬСКИЙ ЦЕНТР

«КОЛЬСКИЙ НАУЧНЫЙ ЦЕНТР РОССИЙСКОЙ АКАДЕМИИ НАУК»

ГОРНЫЙ ИНСТИТУТ

А. Ю. Дьяков, А. И. Калашник

\section{МЕТОДИЧЕСКИЕ ОСНОВЫ ГЕОРАДАРНЫХ ИССЛЕДОВАНИЙ ГОРНОТЕХНИЧЕСКИХ ОБЪЕКТОВ}

KHบ

Издательство Кольского научного центра 2021 
DOI: $10.37614 / 978.5 .91137 .443 .3$

УДК 622.271.332:550.837.76(470.21)

Д 93

Печатается по решению Редакционно-издательского совета

Федерального исследовательского центра «Кольский научный центр

Российской академии наук»

Рецензенты:

Абрамов Н. Н. - кандидат технических наук; Шевиов А. Н. - кандидат физико-математических наук

Дьяков, А. Ю.

Д 93 Методические основы георадарных исследований горнотехнических объектов / А. Ю. Дьяков, А. И. Калашник. - Апатиты : Изд-во ФИЦ КНЦ РАН, 2021. — 110 с.: ил.

ISBN 978-5-91137-443-3

Изложены методические подходы, даны сведения о применяемом оборудовании, и представлены результаты георадарных исследований структуры и состояния горнотехнических объектов западной части российского сектора Арктики. Рассмотрены основные проблемы использования георадаров в этих условиях для нужд горнодобывающей промышленности и способы их решения. Приведены примеры изучения строения массива скальных пород, включающего различные типы структурных неоднородностей, с интерпретацией на основе данных компьютерного моделирования наведенного георадарным зондированием электромагнитного поля. Предложены подходы к оценке нарушенности скальных пород георадиолокацией, в том числе с использованием водонасыщения для контрастности.

Отдельным разделом, имеющим дискуссионную природу, вынесен вопрос о взаимосвязи параметров георадарных исследований и определений напряженного состояния массивов скальных пород. Представлены результаты комплексирования георадарного и сейсмического зондирования насыпных грунтовых сооружений горного профиля для изучения их подповерхностной структуры и локализации в их теле зон различной водонасыщенности грунтов.

Монография может быть полезна специалистам и инженерам горнопромышленных предприятий, а также аспирантам и студентам горногеофизических и гидрогеологических специальностей. Ил. - 88, табл. - 6, библ. - 104 назв.

Научное издание

Редактор С. А. Шарам

Технический редактор В. Ю. Жиганов

Подписано в печать 12.02.2021. Формат бумаги 70×108 1/16

Усл. печ. л. 9.63. Заказ № 2. Тираж 500 экз.

ISBN 978-5-91137-443-3

(С) Дьяков А. Ю., Калашник А. И., 2021

(C) Горный институт ФИЦ КНЦ РАН, 2021

(C) ФИЦ «Кольский научный центр РАН», 2021 


\section{ОГЛАВЛЕНИЕ}

СПИСОК ПРИНЯТЫХ СОКРАЩЕНИЙ...................................

ПРЕДИСЛОВИЕ ....................................................... 5

ВВЕДЕНИЕ ..................................................... 6

1. ГЕОРАДАРНЫЕ ИССЛЕДОВАНИЯ ДЛЯ РЕШЕНИЯ
ГОРНОТЕХНИЧЕСКИХ ЗАДАЧ

1.1. Применение георадарных технологий для исследования горнотехнических объектов................................... 8

1.2. Краткие физические основы георадиолокации...................... 10

1.3. Инструментальный комплекс для проведения экспериментальных исследований................................................. 16

1.4. Проблемы и подходы к применению георадарных исследований горнотехнических объектов..................................... 19

1.5. Георадарные исследования горнотехнических скальных объектов АО «Ковдорский ГОК».......................................... 22

1.5.1. Горизонты +190 м (участок ЦПТ) и +40 м (участок РДКК)....... 22

1.5.2. Исследование участка деформации уступов горизонтов $+70 \ldots+40$ м...

2.1. Теоретические основы............................................. 30

2.2. Горизонтальная структурная неоднородность........................ 31

2.3. Наклонная структурная неоднородность............................. 35

2.4. Вертикальная структурная неоднородность......................... 37

2.5. Пример эмпирического трассирования структурной неоднородности... 38

3. ИЗМЕНЧИВОСТЬ ЭЛЕКТРОФИЗИЧЕСКИХ СВОЙСТВ

НАРУШЕННЫХ И НЕНАРУШЕННЫХ СКАЛЬНЫХ ПОРОД ............. 40

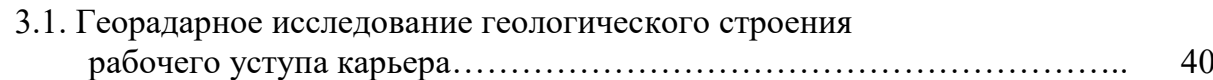

3.2. Влияние массового взрыва на изменчивость электрофизических свойств скальных пород.

3.3. Геофизические признаки нарушенности скальных пород.............. 53

3.4. Оценка нарушенности скальных пород георадарным зондированием с использованием водонасыщения для контрастности................. 57

3.5. Определенные закономерности взаимосвязи параметров георадарных исследований и напряженного состояния пород......... 67

4. ГЕОРАДАРНЫЕ ИССЛЕДОВАНИЯ НАСЫПНЫХ

ГОРНОТЕХНИЧЕСКИХ СООРУЖЕНИЙ

4.1. Примеры георадарных исследований насыпных сооружений..............

4.2. Применение георадарных исследований при решении вопросов перемещения отвалов пород для расширения карьера..................

4.3. Комплексирование георадарных исследований и визуального обследования насыпного сооружения.

4.4. Комплексирование георадарного и сейсмического зондирования насыпного сооружения.

4.5. Роль синхронности при комплексировании волновых исследований..... 94

ЗАКЛЮЧЕНИЕ ..................................................... 101

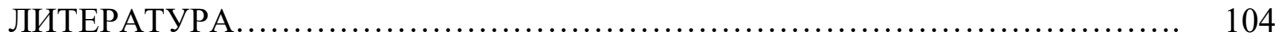




\section{СПИСОК ПРИНЯТЫХ СОКРАЩЕНИЙ}

БВР - буровзрывные работы

ГТС - гидротехническое сооружение

ЗЧРСА - западная часть российского сектора Арктики

MB - массовый взрыв

ПОР — поле обратного рассеяния

РДКК - рудно-доставочный конвейерный комплекс

УГВ - уровень грунтовых вод

ЦПТ - циклично-поточная технология 


\section{ПРЕДИСЛОВИЕ}

Настоящая монография содержит описание применяемых методических подходов, оборудования и полученных результатов георадарных исследований структуры и состояния различных горнотехнических объектов в западной части российского сектора Арктики (ЗЧРСА). Выявленные на основе полученных на протяжении более 10 лет результатов особенности, подтвержденные большим практическим опытом применения георадаров, были направлены на решение текущих и перспективных задач безопасного функционирования горнотехнических объектов в арктических условиях.

Главные положения метода георадиолокации, лежащего в основе применяемых георадаров, обстоятельно изложены в ряде книг и учебных пособий, изданных как в России, так и за рубежом. Среди отечественной литературы, посвященной георадиолокации, прежде всего следует отметить работы М. И. Финкельштейна, М. Л. Владова, А. В. Старовойтова, М. С. Судаковой, С. В. Изюмова, С. В. Дручинина, А. С. Вознесенского. Все они написаны на доступном языке для широкого круга специалистов и охватывают основной круг как решаемых задач, так и проблем применения георадиолокации. Вместе с тем кажущаяся простота метода георадиолокации при его применении на горнотехнических объектах без должного методического обоснования и подготовки зачастую приводит к ошибочной интерпретации, а в итоге к дискредитации метода для решения горнотехнических задач.

Следует также отметить, что, несмотря на то, что в большинстве книг и статей, посвященных георадиолокации, этот волновой метод преподносится как относительно новый или «молодой», он применяется различными компаниями и исследователями для решения различных задач на протяжении уже более 15 лет. Тем не менее, по сравнению с другими геофизическими методами, при использовании которых получено большое количество данных о параметрах исследуемой среды и установлены зависимости между ними и волновыми характеристиками, для метода георадиолокации наблюдается острая нехватка данных экспериментальных (прямых) измерений.

В монографии изложен и систематизирован большой фактический материал по георадарным исследованиям различных горнотехнических объектов, камеральной обработке, анализу и интерпретации полученных результатов. 


\section{ВВЕДЕНИЕ}

Горнодобывающая промышленность в западной части российского сектора Арктики представлена крупными предприятиями: «Норникель» (АО «Кольская ГМК»), «ЕвроХим» (АО «Ковдорский ГОК»), «Фосагро» (КФ АО «Апатит»), «Акрон» (ГОК «Олений ручей» АО «Северо-Западная фосфорная компания), «Северсталь» (АО «Олкон»). В совокупности насчитывается более 300 различных горнотехнических объектов (рудники, карьеры, гидротехнические сооружения хвостохранилищ и водорегулирующих систем), являющихся неотъемлемой частью горнорудного производства. Изучение структуры и состояния горных пород и грунтов этих объектов - это ключевой элемент в вопросах эффективности и безопасности функционирования горнопромышленного предприятия.

Известно, что существенную и определяющую роль играет информация о текущем состоянии пород и грунтов горнотехнических объектов, которую получают на основе данных оперативной оценки и мониторинга их состояния специальными исследованиями: визуальное обследование, геофизические определения, геодезические измерения, сейсмодеформационные определения, пьезо- и реометрия, метод разгрузки, теле- и видеосъемка и др. По этой причине оперативное получение информативных и детализированных данных о геологоструктурных неоднородностях и состоянии пород и грунтов для обеспечения безопасного и эффективного ведения горных работ всегда являлось и является важным и актуальным.

Во многих случаях непосредственное исследование пород и грунтов путем бурения частой сетки скважин оказывается невозможным или очень дорогостоящим, поэтому в дополнение к традиционно применяемым геофизическим методам, способным обеспечить оперативное и качественное получение требуемой информации, использование метода георадиолокации в практике изучения пород и грунтов горнотехнических объектов в ЗЧРСА своевременно и целесообразно.

Опыт применения метода георадиолокации для обнаружения внутренних неоднородностей пород и грунтов, а также выявления особенностей их физических свойств эксплуатируемых месторождений ЗЧРСА, Урала, Сибири и Дальнего Востока РФ дает достаточные основания полагать, что подповерхностное георадиолокационное исследование может быть достаточно эффективно при изучении строения и состояния массивов скальных пород и грунтов.

Тем не менее, несмотря на практику применения метода георадиолокации в горном деле различными исследователями, вопросы оценки геологоструктурного строения массивов скальных пород этим методом все еще остаются недостаточно решенными. Наименее изученными данным методом являются проблемы дифференциации скальных пород по степени нарушенности в уступах карьера, а также выявления и локализации водонасыщенных зон, еще более остро обстоит ситуация для гидротехнических сооружений хвостохранилищ и водорегулирующих систем.

Кроме того, существенным недостатком метода георадиолокации является сложность камеральной обработки полученных данных, а также неоднозначность интерпретации, на качество которой влияет опыт интерпретатора. 
Следовательно, требуется развитие научно-методических основ получения надежных исходных данных, установление взаимосвязей параметров исследуемой среды с волновыми характеристиками георадиолокационной записи для последующей обработки и интерпретации данных, что позволит существенно повысить достоверность обследования и снизить роль субъективных факторов в процессе интерпретации.

В монографии рассматриваются методические основы проведения натурных измерений и интерпретации данных георадарных исследований, полученных с использованием георадарного комплекса Ramac/GPR X3M, оснащенного экранированными антеннами 100, 500, 800 МГц, с примерами применения для решения горнотехнических задач.

Авторы выражает искреннюю признательность: рецензентам - канд. техн. наук Н. Н. Абрамову и канд. физ.-мат. наук А. Н. Шевцову - за ценные советы, обсуждение результатов исследований и замечания, способствовавшие улучшению работы; научным сотрудникам Д. А. Максимову и Д. В. Запорожцу - за помощь в проведении натурных исследований; инженеру О. В. Смирновой - за помощь в подготовке рукописи книги. 


\section{1. ГЕОРАДАРНЫЕ ИССЛЕДОВАНИЯ ДЛЯ РЕШЕНИЯ ГОРНОТЕХНИЧЕСКИХ ЗАДАЧ}

\section{1. Применение георадарных технологий для исследования горнотехнических объектов}

В настоящее время активно развиваются неразрушающие методы изучения массивов горных пород при разведке и эксплуатации горнорудных месторождений.

Помимо перечисленных в предисловии авторов работ, посвященным методу георадиолокации, необходимо отметить исследования таких ученых, как А. В. Омельяненко, Л. Л. Федорова [1], Ю. И. Лещанский, Н. Г. Подшибякин [2], Л. Г. Нерадовский [3], Н. Н. Мельников, А. И. Калашник [4], Р. Р. Денисов, В. В. Капустин, А. В. Синицын [5, 6], В. В. Копейкин, П. А. Морозов, И. В. Прокопович [7], А. М. Кулижников, А. А. Белозеров [8], Б. В. Бучарский, А. Д. Бессонов, И. П. Соколова, Е. О. Зверев, В. И. Овчинников [9], Д. Дж. Дениэлс (D. J. Daniels) [10], Д. Кумлу (D. Kumlu), И. Epep (I. Erer) [11], Б. Маруддани (B. Maruddani), Е. Санди (Е. Sandi) [12] и др.

В области решения геологических и горнотехнических задач с применением метода георадиолокации целесообразно отметить следующих исследователей: П. Н. Александров, Ю. А. Морозов, А. Л. Кулаковский, М. А. Матвеев, А. И. Смульская, Ю. Ф. Соколова [13], А. В. Попов, И. В. Прокопович, Д. Е. Едемский, П. А. Морозов, А. И. Беркут, С. В. Меркулов [14, 15], С. П. Николаев, Б. Н. Заровняев, Л. Л. Федорова, Г. А. Куляндин [16], А. И. Калашник, А. Ю. Дьяков [17, 18], С. В. Андрианов [19], Д. Н. Мусалев, Н. Н. Прохоров, А. М. Клабук [20], А. А. Жуков, А. М. Пригара, И. Ю. Пушкарева, Р. И. Царев и др. [21].

Для реализации метода георадиолокации применяется специально разработанное георадиолокационное оборудование (георадары): российское ОКО, ЛОЗА, ГРОТ, ТР-ГЕО; зарубежное - RАМАС (Швеция), Зонд-12е, Питон3 (Латвия), SIR (США), IDS (Италия), ERA (Англия), RADIANT-EM (Германия), NOGGIN (Канада), OYO (Япония), VIY (Украина), GEOZONDAS (Литва).

Большое количество работ (Л. Л. Федорова, Г. А. Куляндин, К. О. Соколов $[22,23]$, Д. В. Саввин, Л. Л. Федорова, Е. Э. Соловьев [24]) посвящено изучению россыпных месторождений криолитозоны Дальнего Востока, Северо-Запада и юга Якутии, характеризующихся значительным разнообразием и сложностью горно-геологических условий (слоистая структура, зоны повышенной трещиноватости, наличие валунных включений и реликтовых водотоков), для которых хорошо зарекомендовал себя метод георадиолокации. В этих исследованиях большое внимание уделено повышению информативности и точности оценки строения массива горных пород - на основе совершенствования алгоритмов обработки данных с использованием методов статистического анализа, процедур вейвлетанализа, а также оптимизации параметров площадных георадиолокационных наблюдений (К. О. Соколов, Л. Л. Федорова $[25,26])$. Рассмотрены возможности метода георадиолокации при изучении разрывных нарушений на месторождениях полезных ископаемых криолитозоны (К. О. Соколов, П. А.Попков, Н. Д. Прудецкий [27]), детализации структурных особенностей геологических разрезов россыпных месторождений золота (Л. Л. Федорова, Г. А. Куляндин [28]), выявлении 
структурных неоднородностей мерзлого горного массива динамической фильтрацией георадиолокационных сигналов (К. О. Соколов, Л. Л. Федорова, А. В. Омельяненко [29]) и др.

В Западной Сибири опыт применения георадаров (Н. Ю. Никулин, С. М. Простов, О. В. Герасимов [30]) для решения различных задач геотехнологии и геомеханики показал, что они обеспечивают глубинность зондирования до 1720 м с разрешающей способностью до $3 \mathrm{~cm}$, при этом значительно превосходят традиционные электромагнитные методы по оперативности. Георадары также использовались для мониторинга изменения свойств закрепленного массива и электромагнитного сканирования грунтовых оснований горнотехнических сооружений (Н. Ю. Никулин, С. М. Простов $[31,32])$ и др.

ООО «Компания ВНИИСМИ» - известным разработчиком георадаров серии «Лоза» - совместно с сотрудниками ИЗМИРАН накоплен существенный международный опыт (Украина, Германия, Китай, Чили, Индия, Иран) применения метода георадиолокации [33]. Георадары серии «Лоза» относятся к классу геофизических приборов для исследования подповерхностной структуры массива пород на десятки и сотни метров - в зависимости от модели прибора, используемой антенны и параметров зондируемой среды. В горном деле с использованием георадаров «Лоза» проводилось обследование угольного карьера в Бурятии (П. Л. Воровский, С. В. Меркулов, А. С. Подшивалов), в восточной части Кумакского золоторудного узла на Южном Урале для выделения золотоносных кор выветривания, на Колпаковском месторождении медно-цинково-колчеданных руд (Н. А. Ульянцев, В. П. Бородин, П. А. Морозов, А. П. Инговатов, А. Ф. Карпузов), на леднике Гарабаши, г. Эльбрус (П. В. Хлебопашев) и др. Имеется международный опыт обследования рудного тела на участке медного рудника Кордильеры, Чили (С. Курапов, Н. Шилкин), базальтового карьера NICHENICH 5 (Rheinishe Provinzial) в Германии (B. В. Копейкин, А. Н. Козляков, П. А. Морозов и А. Жюстен (Achim Justen)) [33] и др.

Стоит отметить развивающуюся инновационную технологию латвийских компаний "Radar Systems" и "SPH Engineering" на основе применения георадара «Зонд-12е» с беспилотным летательным аппаратом, что, несомненно, позволит вывести применение георадиолокации на больших площадях на совершенно новый уровень съемок.

Анализ применения метода георадиолокации в горном деле за последние 10 лет показал много усовершенствований как в части самого оборудования, так и в технологиях его применения. Так, например, усовершенствование в части увеличения глубинности и информативности получаемых данных было достигнуто за счет понижения частоты излучаемого сигнала и увеличения мощности передатчика, что значительно усилило возможности получения полевых результатов. Существенно возросло число новаций и в камеральной обработке георадиолокационных данных, прежде всего с реализацией 3-мерных систем обработки полученных данных. К. О. Соколовым, Л. Л. Федоровой [25, 26], в частности, уделено большое внимание повышению информативности и точности оценки строения массивов скальных пород на основе совершенствования алгоритмов обработки данных с использованием методов статистического анализа, процедур декомпозиции сигнала, а также применения различного вида фильтраций. 
В то же время основным недостатком применения георадиолокации является сложность получения распределенных скоростных данных. Интерпретация полученных данных, т. е. радарограмм, в подавляющем большинстве случаев производится на основе детального анализа амплитудных, частотных и фазовых характеристик электромагнитного сигнала, сопоставления осей синфазности сигнала внутри выделенных на радарограмме участков или областей, которые отличаются друг от друга характером картины, поверхностями угловых несогласий, интенсивностью отражающих горизонтов. Однако среди новых технологий обработки данных георадиолокации можно выделить инновационную технологию автоматизированного анализа поля обратного рассеяния (ПОР) электромагнитных волн, реализованную в программе ГЕОРАДАР-ЭКСПЕРТ, Позволяющую существенно улучшить качественные и количественные показатели результирующих параметров за счет использования атрибутного анализа волнового поля. Практика применения атрибутного анализа волнового поля для решения горных задач показала существенное повышение качества интерпретации данных георадиолокации и может стать эффективным средством для локализации опасных зон на уступах карьера $[19,34]$. Таким образом, комплексный анализ динамических и кинематических характеристик волнового поля является важнейшим инструментом для решения такого типа задач георадиолокацией.

\section{2. Краткие физические основы георадиолокации}

Принцип действия аппаратуры подповерхностного георадарного зондирования (в общепринятой терминологии - георадара) основан на излучении сверхширокополосных (наносекундных) импульсов, как правило метрового и дециметрового диапазона электромагнитных волн, и приеме сигналов, отраженных от границ раздела слоев зондируемой среды, имеющих различные электрофизические свойства (рис. 1.1). Более подробно основы георадиолокации, как уже упоминалось, описаны в работах исследователей в этой области М. И. Финкельштейна [35], М. Л. Владова [36-38], А. В. Старовойтова [39], Д. Дениэлса (D. Daniels) [10] и др.

Ключевой параметр среды при георадарном зондировании диэлектрическая проницаемость, влияющая на скорость прохождения электромагнитных волн, где отраженные сигналы электромагнитных волн возникают на границах сред с разными скоростями (рис. 1.1) Результатом георадарного зондирования являются временные разрезы, где по горизонтали отмечается расстояние, пройденное георадаром, а по вертикали - время прихода отраженных сигналов в наносекундах.

Для определения скорости электромагнитной волны в среде с учетом ее диэлектрической проницаемости используется формула [36]

$$
V=\frac{c}{\sqrt{\varepsilon}},
$$

где $V$ - скорость распространения электромагнитных волн в среде, $c$ - скорость света, $\varepsilon$ - диэлектрическая проницаемость среды. 


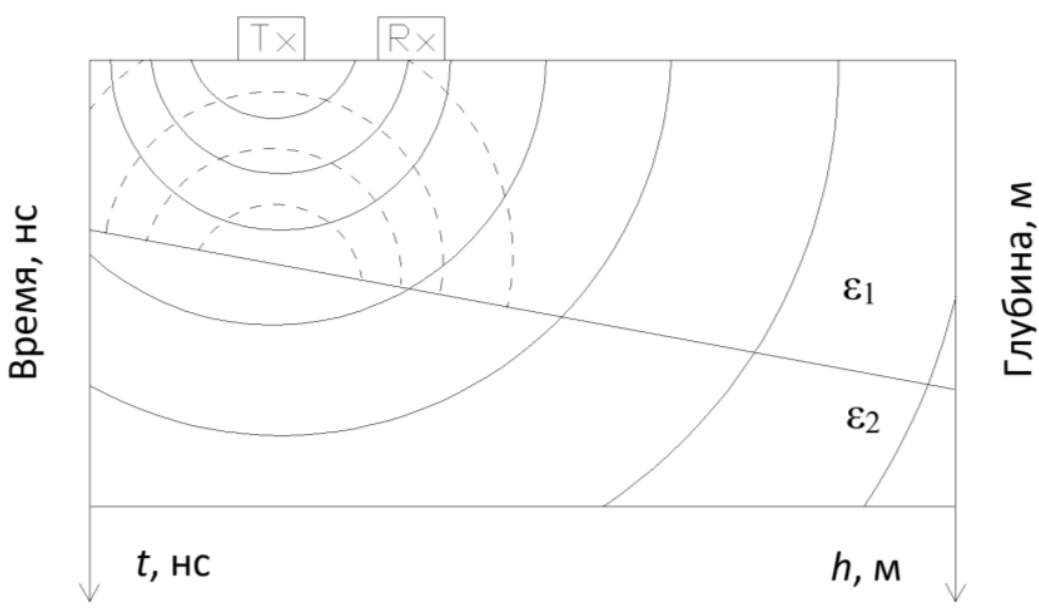

Рис. 1.1. Схема процесса преобразования излученной электромагнитной волны на границе раздела двух сред в массиве пород (Тх-передатчик: сплошные линии - излучаемые электромагнитные волны; Rx-приемник: пунктирные линии - принимаемые отраженные электромагнитные волны, $\varepsilon$ - диэлектрическая проницаемость блока пород)

Для преобразования временного разреза в глубинный необходимо знать скорость распространения электромагнитных волн, или диэлектрическую проницаемость. Определить диэлектрическую проницаемость однородных (сплошных) скальных пород можно на их образцах в соответствии с ГОСТ 2549582 «Породы горные. Метод определения диэлектрической проницаемости и тангенса угла диэлектрических потерь».

В натурных условиях используют три способа определения скорости электромагнитных волн в массивах пород и их диэлектрической проницаемости.

Первый способ - это определение диэлектрической проницаемости и глубины неоднородности по годографу дифрагированной волны, условно называется способом гипербол, он и применим в том случае, когда на радарограмме отчетливо проявляются волновые эффекты в виде гипербол (рис. 1.2). Способ дает приблизительные представления о скоростной характеристике разреза.

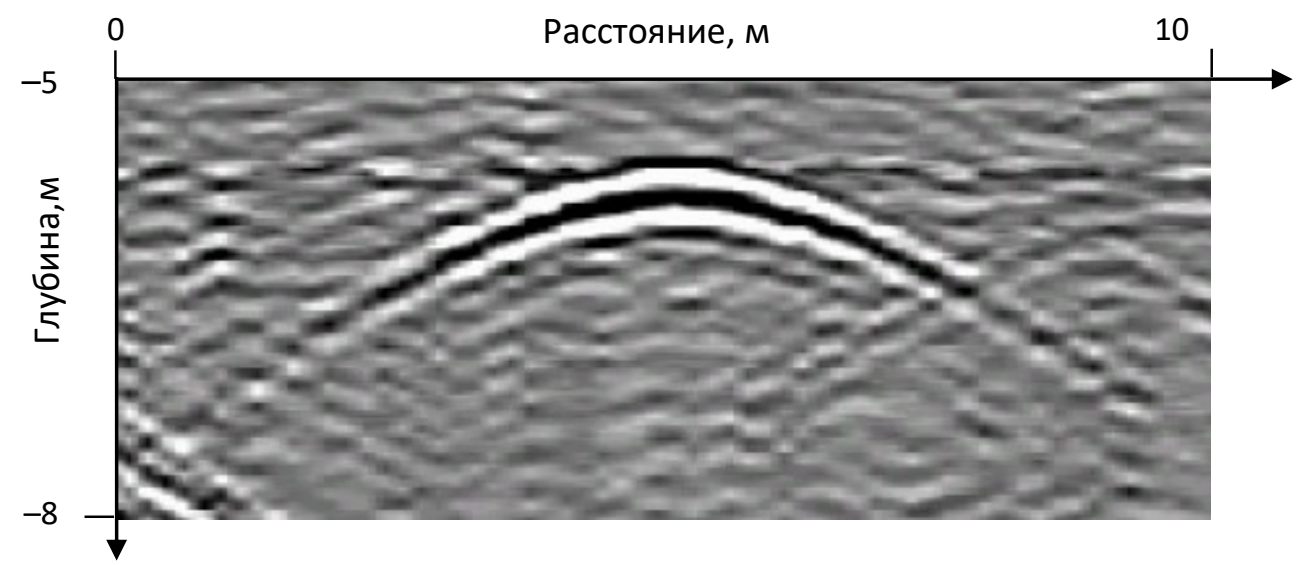

Рис. 1.2. Пример дифрагированной электромагнитной волны на радарограмме массива скальных пород 
Дифракция электромагнитных волн - это явление, которое возникает тогда, когда электромагнитными волнами облучается объект, размеры которого меньше преобладающей длины волны. Суть явления состоит в том, что в соответствии с принципом Гюйгенса каждая точка фронта волны представляет собой элементарный вторичный источник волн [36-39]. На небольшой, в сравнении с длиной волны, поверхности объекта эти элементарные источники складываются. В итоге весь объект представляет собой вторичный источник электромагнитных волн в исследуемой среде.

Дифракция - это важное для георадиолокационных исследований явление, которое позволяет определить глубину залегания объекта и скорость распространения электромагнитных волн в среде над объектом. Дифрагированная волна на радарограмме выражается в виде гиперболы (годографа дифрагированной волны), описываемая следующим уравнением [36-39]:

$$
t(x)=\frac{2 L}{V}=\frac{2 \sqrt{x^{2}+h^{2}}}{V},
$$

где $L-$ путь, пройденный волной; $V$ - скорость волны; $h$ - глубина залегания объекта, $x$ - координата по горизонтали.

Ниже приведен пример определения скорости распространения волн в скальных породах уступа карьера. Исследование проводилось компарационным методом, который основан на использовании дифрагированных волн [36]. Данные полевых измерений обрабатывались в программе RadExplorer, и математически рассчитанная гипербола при этом совмещалась с осью синфазности на экране, ее параметры регулировались методом итераций до полного совмещения. Таким образом, посредством итераций дифракций была определена скорость распространения волн в скальных породах уступа карьера, которая составила $10,3 \mathrm{~cm} / \mathrm{Hc}$, что соответствует диэлектрической проницаемости 8,5 (рис. 1.3).

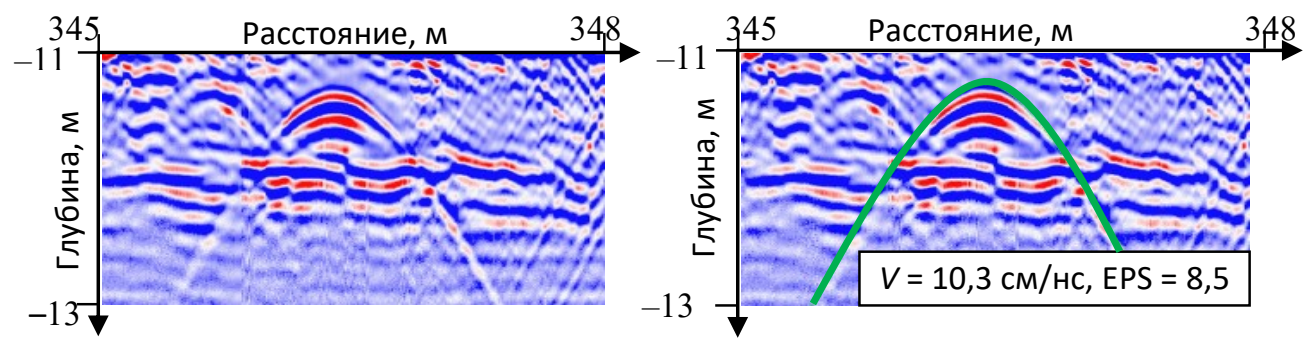

Рис. 1.3. Совмещение теоретического годографа с дифрагированной волной

Второй способ - это определение диэлектрической проницаемости и глубины неоднородности по годографу отраженной волны. Этот способ оценки скоростей может быть реализован по данным многоканальных измерений или по измерениям одноканальных радаров, с возможностью изменения расстояния между передающей и приемной антеннами (метод построения годографа на основе задержки сигнала). Определение значения скорости электромагнитной 
волны от поверхности до выявленной границы или от выявленной границы до следующей границы следует осуществлять с учетом параметров расстояния между приемной и передающей антеннами (базы антенны).

Метод отраженных волн [38], или общей глубинной точки, заключается в получении радарограммы при симметричном разносе приемной и передающей антенны георадара относительно измеряемой точки на поверхности земли [40]. Геометрия прохождения сигнала показана на рис. 1.4.
Передатчик
Приемник
2 поз. 1 поз.
1 поз. 2 поз.

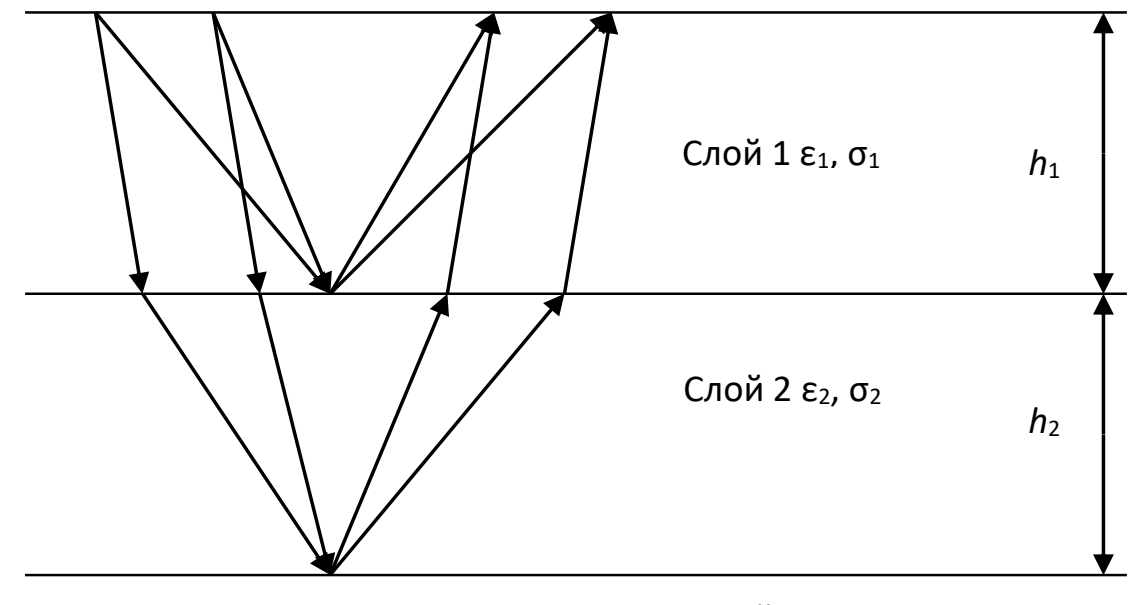

Слой $3 \varepsilon_{3}, \sigma_{3}$

Рис. 1.4. Геометрия прохождения сигнала [40]

Для вычисления скорости электромагнитной волны в исследуемых средах используется определение скорости по годографу отраженной волны (рис. 1.5). Сущность построения годографа заключается в том, что точки приема и передачи разносятся в пространстве. Этот метод является основным для определения истинной глубины неоднородности или объекта, скорости распространения электромагнитных волн, а также необходим при отсутствии на радарограмме дифрагирующих объектов и какой-либо иной возможности получения сведений о скоростях распространения волн в среде [35-39].

Годограф - это зависимость времени задержки сигнала $t$ от расстояния $d$ между приемником и передатчиком, задается формулой [40]

$$
t=2 \frac{\sqrt{\varepsilon}}{c} \sqrt{h^{2}+\frac{d^{2}}{4}},
$$

где $t$ - время задержки сигнала; $d-$ расстояние между приемником и передатчиком, $h-$ глубина до границы отражения, $c-$ скорость света, $\varepsilon-$ диэлектрическая проницаемость. 
Синхронизация осуществляется по воздушной волне от зондирующего импульса передатчика [40], поэтому начало регистрации отстает от времени излучения:

$$
t^{\prime}=d / c
$$

то есть [40]

$$
t=2 \frac{\sqrt{\varepsilon}}{c} \sqrt{h^{2}+\frac{d^{2}}{4}}-\frac{d}{c} .
$$

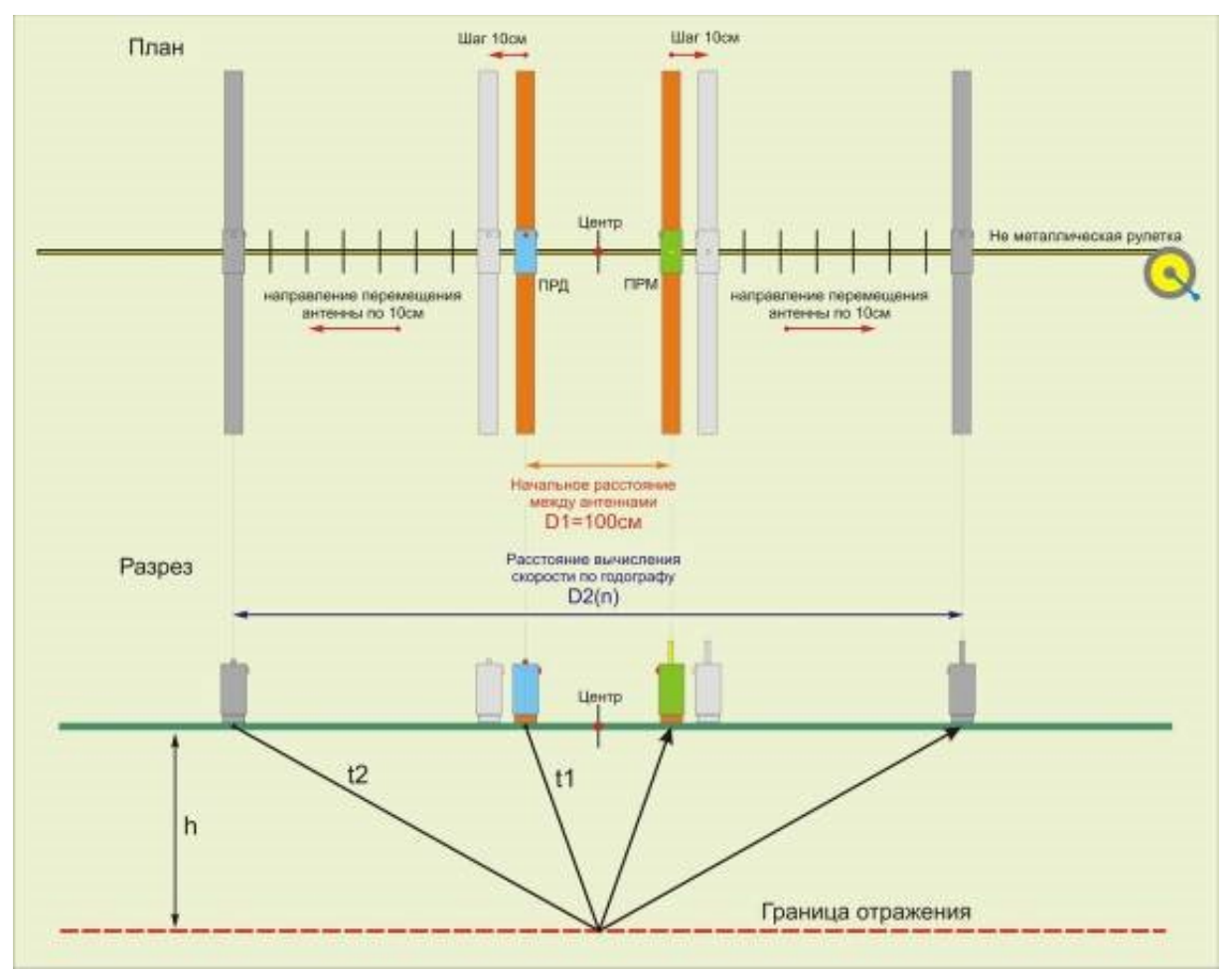

Рис. 1.5. Схема зондирования для получения годографа [40]

По двум измерениям задержек сигнала $t_{1}$ и $t_{2}$ на расстояниях между приемником и передатчиком $d_{1}$ и $d_{2}$ по уравнению годографа определяют мощность слоя $h_{1}$, скорость электромагнитной волны $V$ в слое и его диэлектрическую проницаемость $\varepsilon_{1}$ по следующим формулам [40]:

$$
\begin{gathered}
h_{1}=\sqrt{\frac{t_{2}^{2} d_{1}^{2}-t_{1}^{2} d_{2}^{2}}{4\left(t_{1}^{2}-t_{2}^{2}\right)}} ; \\
V=\frac{c}{2} \sqrt{\frac{d_{1}^{2}-d_{2}^{2}}{\left(c t_{1}+d_{1}\right)^{2}-\left(c t_{2}+d_{2}\right)^{2}}} \\
\varepsilon_{1}=\frac{t_{1}^{2} c^{2}}{4 h_{1}^{2}+d_{1}^{2}} .
\end{gathered}
$$


На рис. 1.6 представлен пример радарограммы с годографом отраженной волны по методу общей глубинной точки, где рис. $1.6 a-$ исходная радарограмма, рис. 1.66 - с выделенным годографом отраженной волны. Таким образом, скорость электромагнитной волны в среде составила $V=6,4$ см/нс, со значением диэлектрической проницаемости $\varepsilon=5,5$.

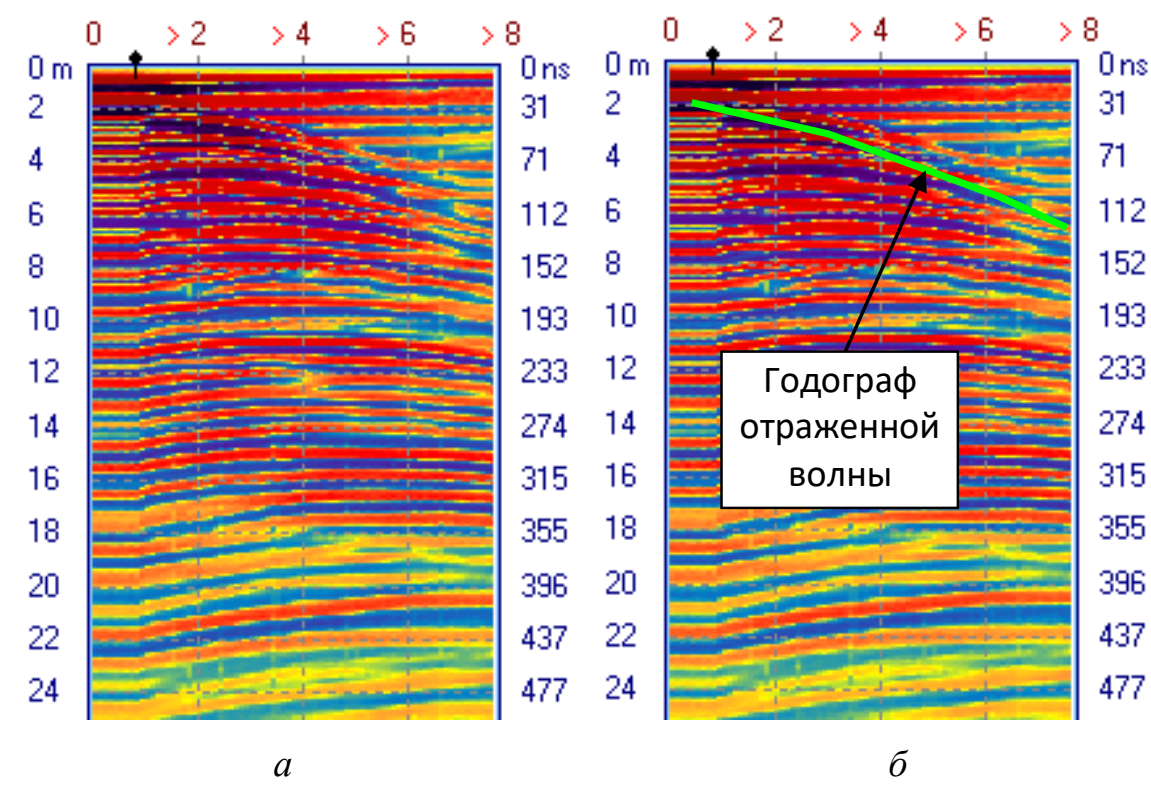

Рис. 1.6. Радарограмма с годографом отраженной волны (по горизонтальной шкале указано расстояние, по вертикальной — глубина, м)

Tpemий способ - определение глубины слоя и вычисление усредненного значения диэлектрической проницаемости и скорости электромагнитной волны по данным геологических скважин, так называемый «принцип калибровки». Принцип калибровки заключается в одновременном определении глубины геологических слоев двумя методами - по скважине и георадаром, с последующим их сопоставлением. Затем с помощью компьютерной программы обработки георадарных данных, итерационно изменяя значение диэлектрической проницаемости или скорости электромагнитной волны, выявленную границу на радарограмме совмещают с глубиной границы, определенной по геологической скважине. Если границ (слоев) по скважине несколько, данная процедура повторяется для следующего слоя; таким способом строится скоростная модель исследуемого участка пород. На рис. 1.7 представлен механизм определения глубины слоя по данным геологической скважины, где граница скального основания находится на 6 м, таким образом, скорость электромагнитной волны $V$ в моренном слое составила $9,05 \mathrm{~cm} /$ нс, диэлектрическая проницаемость $\varepsilon-11$.

Основным и самым важным этапом в георадиолокации является качественная и/или количественная интерпретация радарограмм (временных разрезов), на которых по горизонтали указано расстояние в метрах, по вертикали время двойного пробега волны, с амплитудными значениями, отражающими строение массива скальных пород. 
Интерпретация данных георадиолокации заключается в детальном анализе полученных данных и количественной интерпретации волновой картины посредством геофизических критериев внутри выделенных на радарограмме участков или областей, которые отличаются друг от друга характером рисунка либо поверхностями угловых несогласий, либо интенсивными отражающими горизонтами.

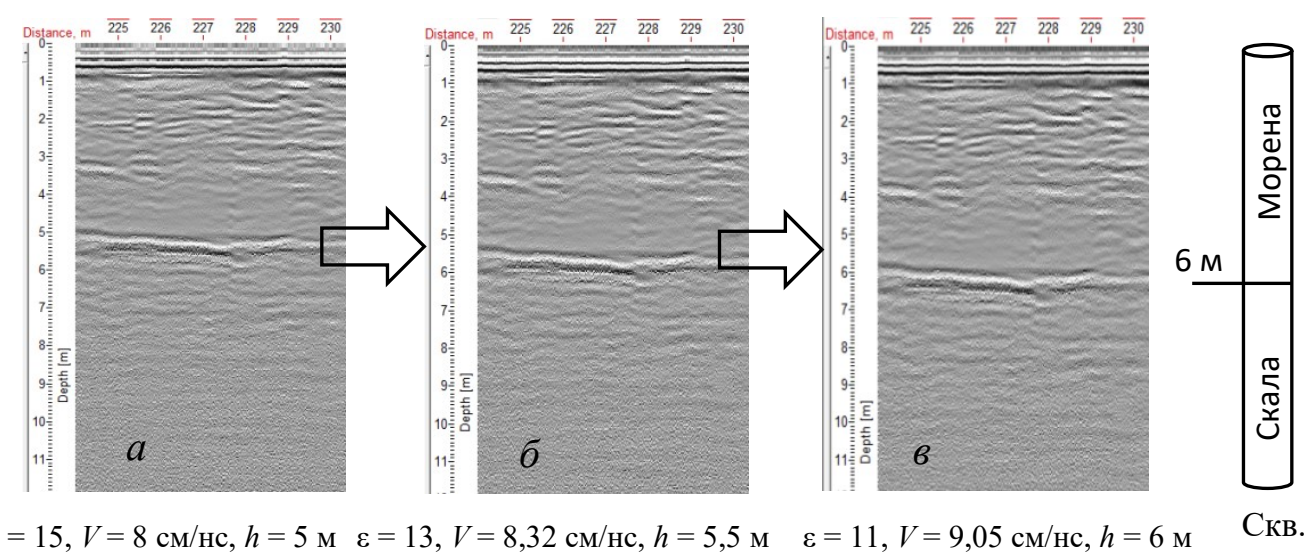

Рис. 1.7. Определение глубины слоя по данным геологической скважины

\section{3. Инструментальный комплекс для проведения экспериментальных исследований}

При проведении исследований законтурного массива пород был применен георадарный комплекс Ramac GPR/X3M (производства компании MalaGeoScience, Швеция), к характерным особенностям которого следует отнести модульность, высокое качество и оперативность получаемых данных.

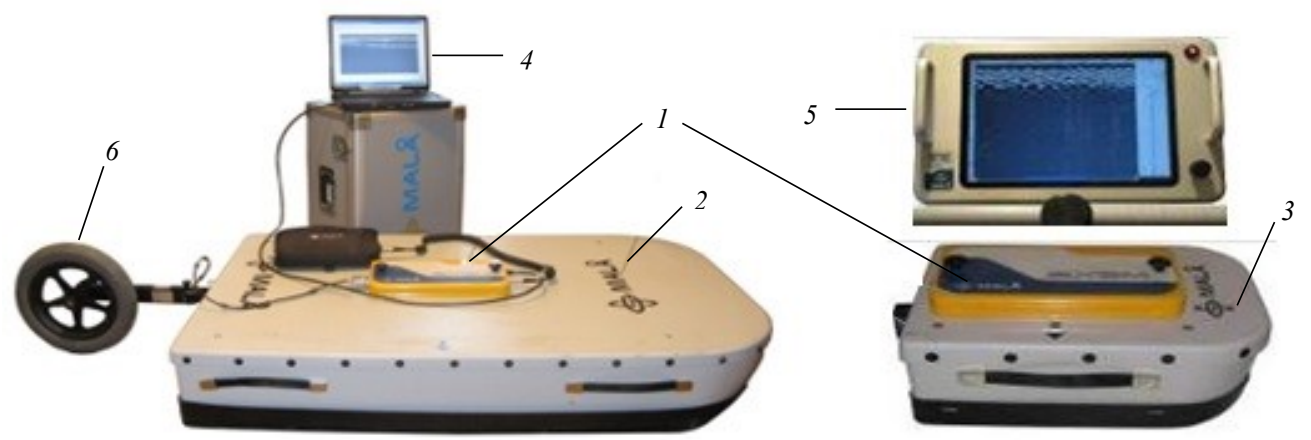

Рис. 1.8. Базовый рабочий комплект георадарного комплекса Ramac GPR/X3M: 1 - блок управления X3М; 2, 3 - экранированные антенны 100 и 500 МГц; 4 - внешний персональный компьютер; 5 - специализированный модуль управления и визуализации (монитор Ramac XV10); 6 - одометр 
Базовый рабочий комплект георадарного комплекса Ramac GPR/X3M содержит блок управления Х3M, антенны и внешний персональный компьютер или специализированный модуль управления и визуализации (монитор Ramac XV10), который обрабатывает принятый сигнал и отображает полученные данные на дисплее (рис. 1.8).

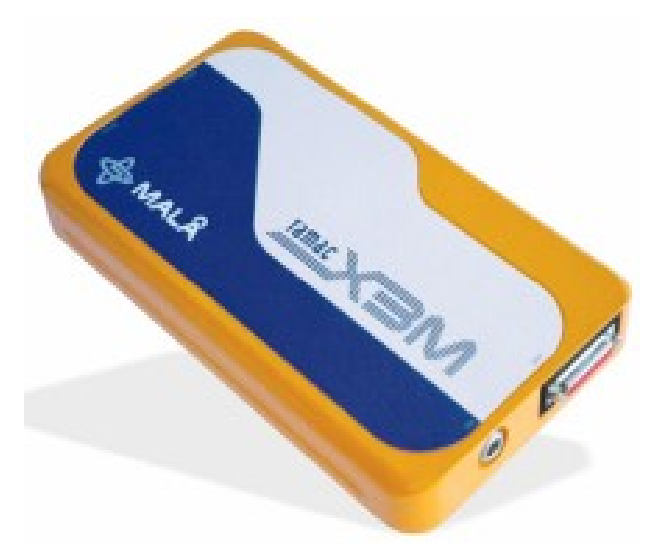

Рис. 1.9. Блок управления RamacGPR/X3M

Георадарный комплекс с блоком управления Ramac GPR/X3M (рис. 1.9) работает следующим образом: Х3М посылает синхронизирующий сигнал модулям (передающему и приемному). После его получения передатчик генерирует и посылает электрический импульс в антенну. От антенны импульс распространяется в изучаемую среду, в ней он отражается от различных неоднородностей и возвращается к приемнику.

Приемник после получения синхронизирующего сигнала начинает накапливать выборки с определенной периодичностью по времени и передавать их блоку управления Х3М. Блок управления Х3М помещает каждую поступающую выборку на соответствующее место в данной трассе. Когда трасса будет полностью сформирована, она посылается на компьютер, где сохраняется на жестком диске компьютера и отображается на мониторе.

При проведении съемки вся система перемещается по траектории наблюдения, получая и записывая трассы с определенным шагом по расстоянию или по времени. В результате получается непрерывный профиль - запись подповерхностных условий вдоль линии наблюдения, называемая радарограммой. Технические характеристики блока управления RamacGPR/X3M представлены в табл. 1.1.

Экранированные антенны RAMAC (рис. 1.10) содержат передающий и приемный антенные элементы в едином корпусе. Приемный элемент находится в передней, а передающий - в задней части корпуса.

Таблица 1.1

Технические характеристики блока управления RamacGPR/X3M

\begin{tabular}{|l|l|}
\hline Разрядность, бит & 16 \\
\hline Временной интервал зондирования, нс & До 2000 \\
\hline Количество точек в трассе & $128-8192$ (1024 в режиме автонакопления) \\
\hline Скорость передачи данных, кб/с & $40-400$ \\
\hline $\begin{array}{l}\text { Частота повторения импульсов } \\
\text { передатчика, кГц }\end{array}$ & 100 \\
\hline Передача данных & IEEE 1284(ЕСР) \\
\hline Количество накоплений & $1-32768$ \\
\hline Режимы регистрации данных & По времени, по перемещению, по шагам \\
\hline
\end{tabular}


Окончание таблицы 1.1

\begin{tabular}{|l|l|}
\hline Привязка данных на местности & $\begin{array}{l}\text { С помощью датчиков перемещения, } \\
\text { GPS или вручную }\end{array}$ \\
\hline Поддерживаемые антенны & Экранированные антенны 100-800 МГц \\
\hline Питание, В & 12 Li-Іоп аккумулятор \\
\hline Размеры, мм & $310 \times 180 \times 30$ \\
\hline Вес, кг & 1,7 \\
\hline Рабочая температура, ${ }^{\circ} \mathrm{C}$ & $-20 \ldots+50$ \\
\hline Пылевлагозащита & IP 67 \\
\hline
\end{tabular}

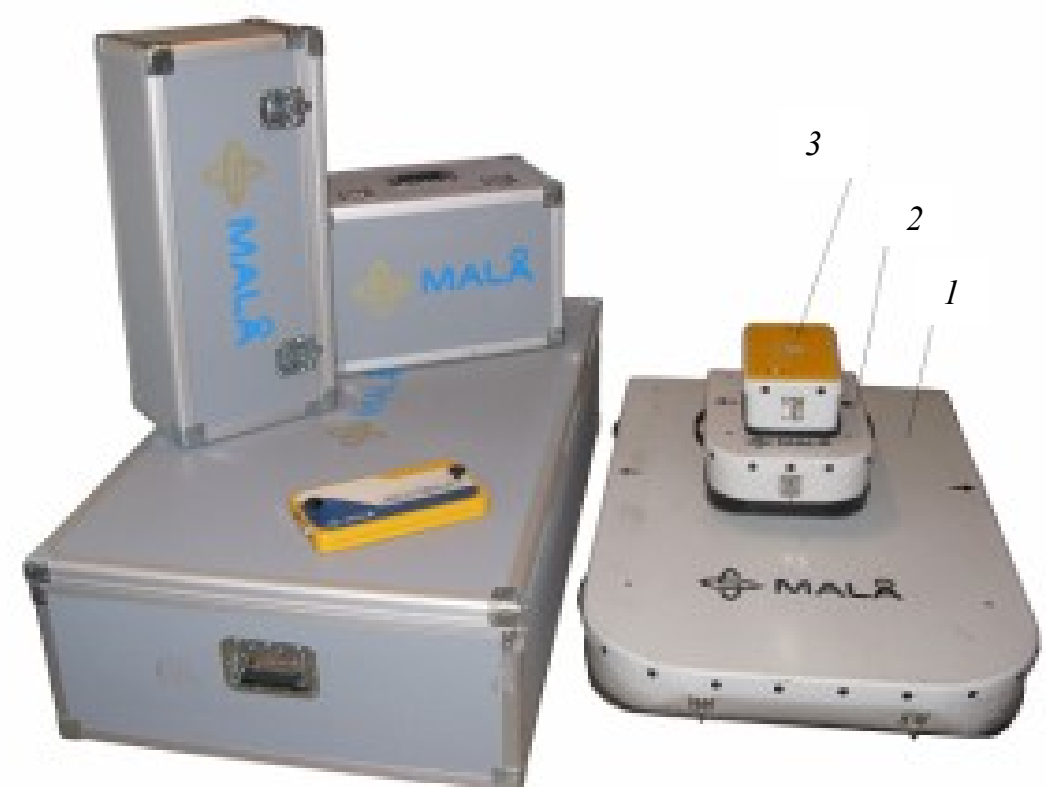

Рис. 1.10. Экранированные антенны 100 (1), 500 (2), 800 (3) МГц (MalaGS)

Таблийа 1.2

Технические характеристики антенн георадарных систем

\begin{tabular}{|l|c|c|c|c|c|c|c|}
\hline $\begin{array}{l}\text { Частота } \\
\text { антенны, МГц }\end{array}$ & 10 & 50 & 100 & 200 & 300 & 500 & 800 \\
\hline Тип волны & Короткие & \multicolumn{6}{|c|}{ Ультракороткие } \\
\hline Диапазон & Декаметровые & \multicolumn{5}{|c|}{ Метровые } & \multicolumn{2}{|c|}{ Дециметровые } \\
\hline Длина волны, м & 30 & 6 & 3 & 1,5 & 1 & 0,6 & 0,375 \\
\hline $\begin{array}{l}\text { Разрешающая } \\
\text { способность, м }\end{array}$ & 0,6 & 0,2 & 0,1 & 0,1 & 0,05 & 0,04 & 0,02 \\
\hline $\begin{array}{l}\text { Максимальная } \\
\text { глубина } \\
\text { обследования, м }\end{array}$ & 250 & 80 & 35 & 30 & 25 & 20 & 10 \\
\hline
\end{tabular}


Технические характеристики антенн георадарных систем представлены в табл. 1.2, максимальная глубина обследования зависит от типов обследуемых пород/грунтов.

Экранированный тип антенн отличается тем, что большая часть энергии излучается только в нижнюю полусферу пространства. То же относится и к принимаемым сигналам: экранированные антенны слабо чувствительны, к электромагнитным волнам, пришедшим из пространства над антенной.

\section{4. Проблемы и подходы к применению георадарных исследований горнотехнических объектов}

К основным проблемам применения метода георадиолокации на горнотехнических объектах можно отнести субъективную интерпретацию получаемых данных, а также отсутствие обоснованных геофизических признаков выявления различных объектов на выделенных условных аномалиях волнового поля. Во многих случаях, при отсутствии должной априорной информации об объекте исследования, происходит «притягивание» данных к «нужному» результату, что в дальнейшем очень сильно сказывается на репутации метода для этих задач. Поэтому специалисты, использующие данный метод, вынуждены привлекать другие методы исследования, комплексировать, например с электропрофилированием, или использовать сейсмический метод, посредством которого уже установлены взаимосвязи параметров среды. С одной стороны, все это приводит к значительному удорожанию работ, с другой стороны, утрачивается одна из самых востребованных особенностей метода - оперативность и возможность получать информацию в так называемом режиме in-situ (на месте). Полученные на одном объекте значения параметров среды по георадиолокационным данным, в большинстве случаев, не подходят для использования на другом. Разнообразие пород и грунтов со своими отличными признаками слагаемой ими среды вынуждает специалистов в области георадиолокации искать новые пути решения, основываясь на созданных другими исследователями методических подходах по выявлению различных критериев, например, по определению зон нарушенности пород и водонасыщения, выявлению структурных неоднородностей и многое другое.

Организация и проведение георадиолокационных исследований на горнотехнических объектах в подавляющем большинстве случаев используется для оценки их состояния, выявления и трассирования подповерхностных геологоструктурных неоднородностей скальных пород и грунтов, а также выявления водонасыщенных зон.

Применение георадиолокационных исследований горнотехнических объектов на рудниках позволило решать следующие задачи:

- определение состояния, структуры и текстуры скальных пород уступов карьера;

- получение детализированной информации об основных элементах внутреннего строения пород;

- выявление, трассирование и локализация подконтурных (скрытых) геолого-структурных неоднородностей в массиве скальных пород. 
Согласно атласу физических свойств минералов и пород Хибинских месторождений, относительная диэлектрическая проницаемость минералов апатит, нефелин и пироксенит - равняется 6, 7,5 и 13 соответственно [41].

На основе многочисленных георадарных определений на различных объектах горного производства было выявлено, что для скальных пород значения диэлектрической проницаемости ненарушенного массива составляют 5-8 и 8-18 - для массива, ослабленного трещинами и структурными неоднородностями.

В свою очередь, хвостохранилища обогатительных фабрик и ограждающие их дамбы также являются важными объектами горного предприятия как его неотъемлемая часть. Здесь исследование слагающих дамбу грунтов методом георадиолокации выполняется для решения проблемы предотвращения аварий, вызываемых процессами повышенной фильтрации. Существенной особенностью этой проблемы является то, что возникающие и развивающиеся в теле сооружений фильтрационные процессы на начальных этапах их формирования визуально и традиционными методами не фиксируются.

Применение георадиолокационных исследований горнотехнических объектов на ГТС хвостохранилищ позволяет решать следующие задачи:

- определение состояния, структуры и однородности намывных и насыпных грунтов;

- получение детализированной информации о ГТС, включая подстилающее геологическое основание;

- трассирование депрессионной поверхности фильтрующихся вод;

- выявление и локализация зон повышенной фильтрации.

На основе многочисленных георадарных определений для насыпных грунтов ГТС хвостохранилищ значения диэлектрической проницаемости составляют: для сухих и плотных грунтов естественной влажности - 7-10; для водонасыщенных грунтов - 10-18.

Проведение полевых георадиолокационных работ включало в себя следующие этапы:

1. Изучение имеющихся данных геологических разрезов и скважин, находящихся в пределах или в непосредственной близости обследуемого объекта (участка), а также расположения других промышленных объектов, и уровня их техногенного электромагнитного воздействия.

2. Компоновка оборудования, необходимого для достижения требуемой глубины исследования и разрешающей способности съемки.

3. Настройка управляющих параметров блока управления, шага профиля и времени двойного пробега волны - для обеспечения необходимой глубины зондирования и оптимальной разрешающей способности георадиолокационной съемки.

4. Разработка организационно-технической программы георадиолокационной съемки, которая должна включать в себя методику полевых исследований и схему георадарных профилей.

Для целей картирования протяженных границ горно-геологических структур георадарные профили прокладываются, по технической возможности, параллельно друг другу между скважинами (рис. 1.11). 


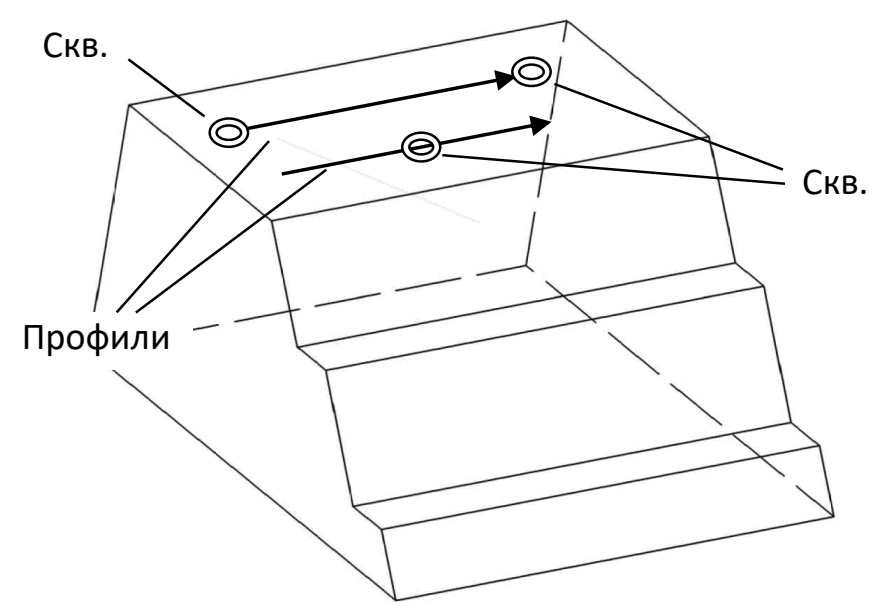

Рис. 1.11. Параллельное профилирование между опорными скважинами

Для целей идентификации протяженных горно-геологических дислокаций, длина которых много больше поперечных размеров, профили располагаются, по технической возможности, параллельно по короткой оси дислокации (рис. 1.12). Для целей картирования локальных горногеологических структур проектируется сетка профилей - ряды параллельных и перпендикулярных профилей, покрывающих участок уступа (рис. $1.13, a$ ).

Далее производится предварительная съемка - для оценки информативной глубинности получаемых данных и определения предварительных параметров массива пород (диэлектрическая проницаемость исследуемых пород, скорость распространения электромагнитной волны).

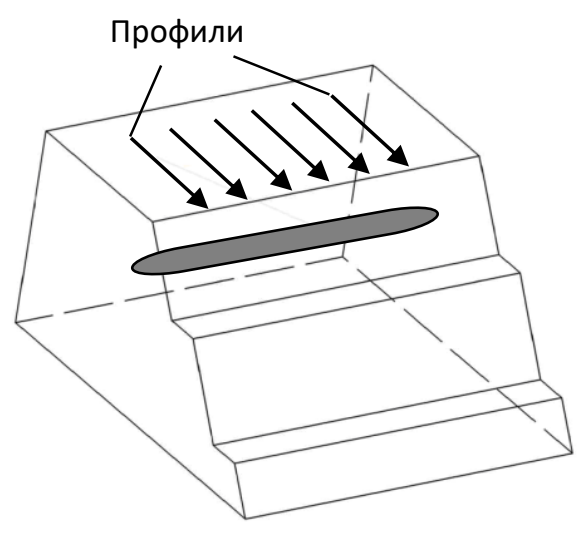

$a$

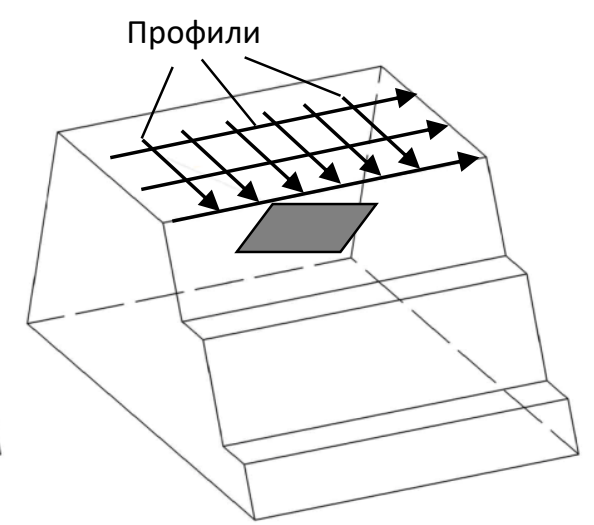

6

Рис. 1.12. Картирование протяженных геологических дислокаций, длина которых много больше их поперечных размеров $(a)$, локальных горно-геологических структур (б)

Визуальным анализом полученных данных (радарограмм) на дисплее управляющего блока, при наличии аномалий в волновой картине, предварительно идентифицируется вид внутренней неоднородности: зона нарушенных пород, геологическая дислокация (наклонная, субвертикальная, линзовидная), зона 
повышенного водонасыщения пород. На основе этого выполняется корректировка управляющих параметров (шаг профилирования, время двойного пробега электромагнитной волны и др.), которые должны в наибольшей степени соответствовать идентифицированному типу неоднородности.

При апробации разработанной методики возникали различного рода методические и технические вопросы, присущие непосредственному исследуемому горнотехническому объекту. Описанию решения этих вопросов посвящены следующие разделы данной работы.

\section{5. Георадарные исследования горнотехнических скальных объектов АО «Ковдорский ГОК»}

\subsection{1. Горизонты +190 м (участок ЦПТ) и +40 м (участок РДКК)}

Предыдущими исследованиями авторов было показано, что метод георадиолокации применительно к карьерам может использоваться для определения внутренней структуры массива пород, обнаружения полостей, кварцевых гнезд, интрузий и т. п., а также для выявления локализации природных и техногенных зон нарушенности в законтурном массиве пород, геологической слоистости, неоднородности, водонасыщенности и проч. [42].

На карьере «Железный» АО «Ковдорский ГОК» исследования методом георадиолокации были выполнены на уступах горизонтов +190 м (участок ЦПТ - циклично-поточной технологии) и +40 м (участок РДКК - руднодоставочного конвейерного комплекса). Всего на этих участках было получено 67 георадарных профилей общей протяженностью около 7 км с реализацией задач приповерхностного зондирования на глубину до 40 м.

По данным георадарных исследований по уступам на участке ЦПТ построены соответствующие радарограммы, выполнены анализ и интерпретация их волновых картин в целях выделения внутренних геологических структур и дислокаций (рис. 1.13, 1.14).

Как видно из рис. 1.13, приповерхностная зона профиля на глубину до 4 м характеризуется равномерной «плотной» (контрастной) волновой картиной, что соответствует раздробленным/разрушенным, но уплотненным породам. Далее, до глубины примерно 20 м, выделяется слой, в пределах которого породы имеют другие электрофизические свойства.

На радарограмме (рис. 1.13) также выделяются геологические структуры, зоны неоднородности и геологические дислокации. В начале профиля, на глубине около 8 м, прослеживается трещина с углом падения $22^{\circ}$ до глубины примерно 17 м. На интервале 250-270 м профиля выделяются две пересекающиеся на глубине 11 м трещины такого же характера.

На радарограмме также выделяются две геологические структуры (отмечены пересекающейся штриховкой), схожие по своим электрофизическим свойствам, которые могут быть отнесены к зонам нарушенности пород; первая - на интервале профиля 225-255 м, на глубине 13 м, мощностью около 2 м, расположенная субгоризонтально (в плоскости профиля), вторая на интервале профиля 240-265 м, на глубине 31 м, мощностью около 3 м, разорванная двумя нарушениями в левой и одним разломом в правой ее части, со сдвигом центральной части структуры вниз. 


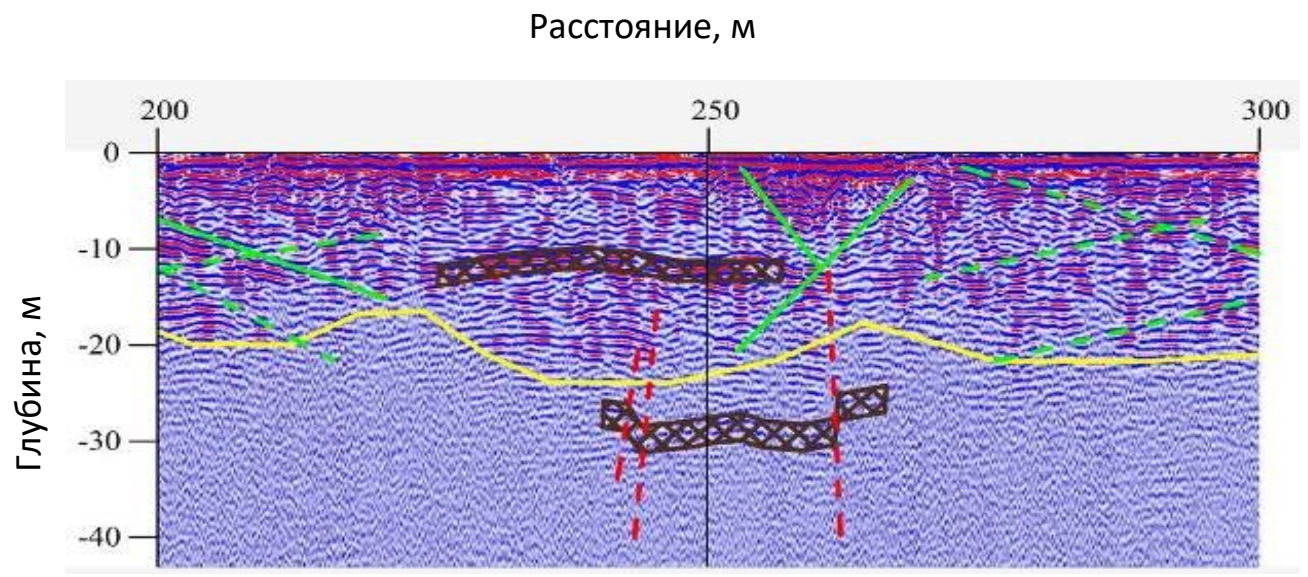

Рис. 1.13. Фрагмент продольного георадиолокационного профиля по гор. +190 м, участок ЦПТ

Условные обозначения

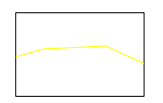

Прослеженные границы пород с
различными электрофизическими свойствами

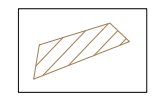

Геологические структуры

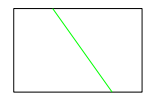

Выявленные

трещины

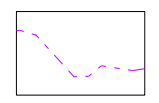

Неинтерпретированная граница

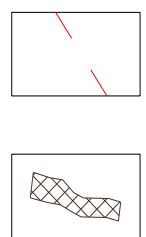

Предполагаемые

трещины

Зона структурного

нарушения

Рис. 1.14. Легенда к фрагментам радарограмм участков ЦПТ и РДКК

На участке РДКК (рис. 1.15) георадиолокационные исследования были выполнены на уступе горизонта +40 м, по данным которых были построены радарограммы (фрагмент продольного профиля представлен на рис. 1.16).

Как видно на радарограмме рис. 1.16, приповерхностная зона профиля мощностью до 4 м характеризуется равномерной «плотной» волновой картиной с небольшим количеством наклонных трещин (раздробленный слой пород). Следующая зона мощностью около 15 м соответствует разуплотненным породам, далее, с глубины примерно 20 м, породы менее разуплотнены.

На интервале 230-250 м профиля отмечаются три субвертикальных трещины с изменением формы сигнала электромагнитной волны, где, предположительно по косвенным признакам, проходит тектонический разлом.

На профиле также выделяются две геологические структуры: первая наклонная, на интервале 200-230 м, с глубины 15 м, мощностью 7-10 м, выходящая под углом $15^{\circ}$ практически на поверхность, и вторая - субвертикальная, 
на интервале от 284 до 291 м, на глубинах от 9 до 33 м. При этом вторая структура разделяет исследованный массив пород в вертикальной плоскости на две зоны с различными электрофизическими свойствами.

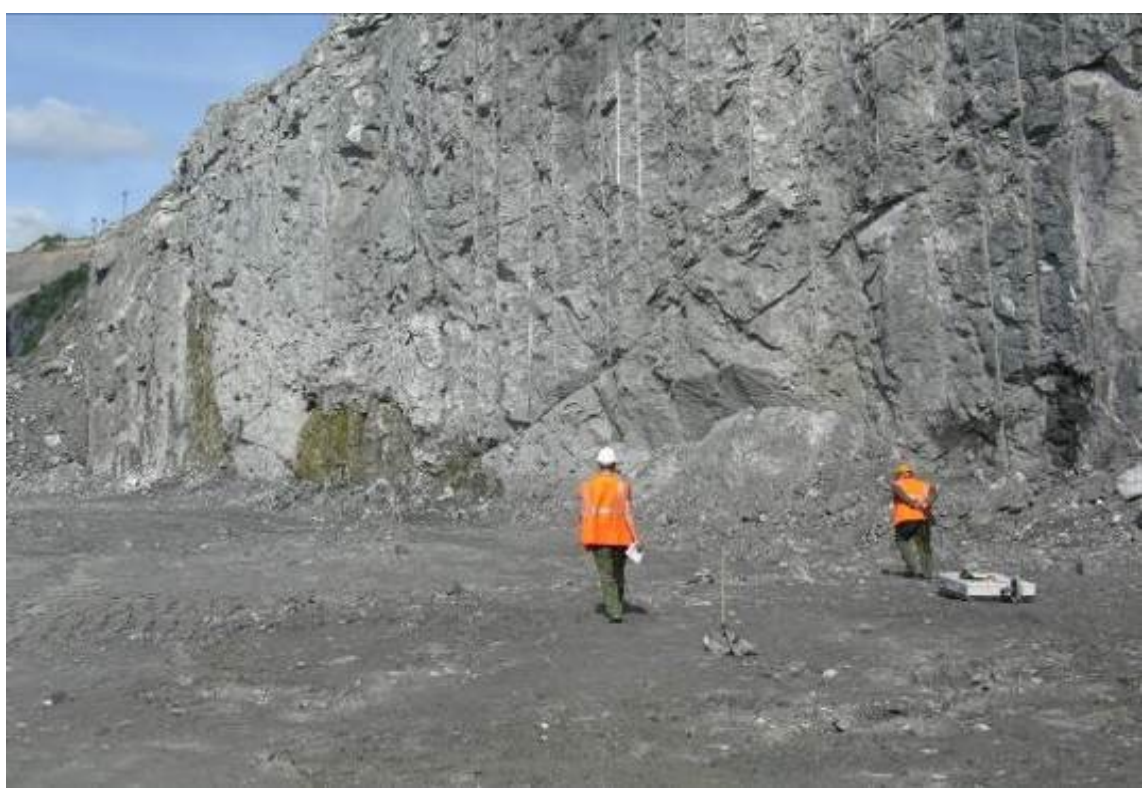

Рис. 1.15. Экспериментальные исследования участка уступа гор. +40 м георадарным комплексом RAMAC/GPR X3M

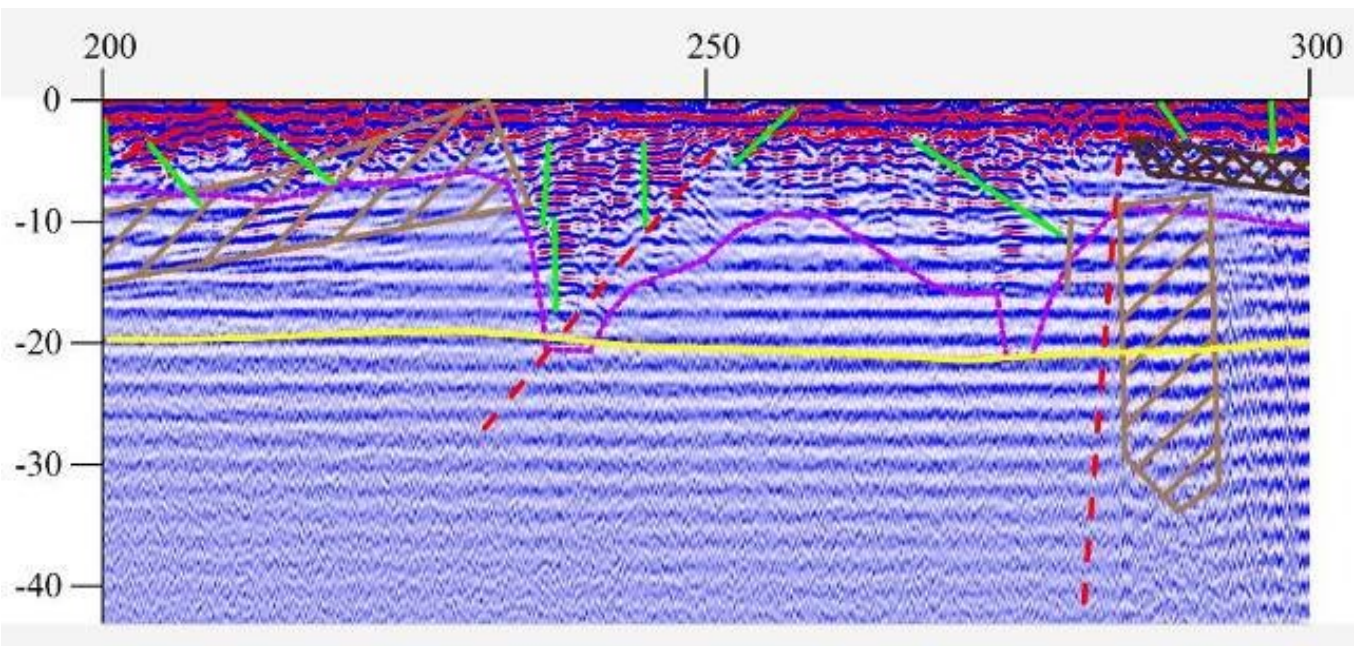

Pис. 1.16. Фрагмент продольного профиля по уступу гор. +40 м, участок РДКК

В конце профиля, на интервале 285-300 м, контрастно выделяется зона (мощность 3 м), которая располагается на глубине от 3 до 7 м и может быть приурочена к структурному нарушению.

Таким образом, георадарными исследованиями выявлены особенности структуры и состояния массива пород для участков измерений. Эти признаки 
могут быть учтены при оценке устойчивости как уступов на локальных участках, так и борта карьера в целом.

Для целей обоснования параметров новых уступов на горизонте 40 м участка РДКК рекомендуется принимать во внимание в первую очередь следующие выявленные особенности структуры массива пород:

- слоистость зональность пород массива на глубинах до 4, 20 м и до 4060 м (может быть обусловлена неравномерным напряженным состоянием пород, неоднородностью пород, распределением внутрипородных вод);

- наличие пологопадающих дислокаций, выделяемых на основе анализа радарограмм;

- наличие субвертикальных и наклонных структур, которые прослеживаются практически на всех уступах участков ЦПТ и РДКК.

\subsection{2. Исследование участка деформации уступов горизонтов $+70 \ldots+40$ м}

28 апреля 2015 г. произошла деформация (обрушение) уступов горизонтов $+70 \ldots+40$ м южного борта карьера «Железный» АО «Ковдорский ГОК». Деформированный участок борта карьера исследовался с применением методов визуального наблюдения и фотосъемки. На деформацию специалистами комбината был составлен паспорт, в котором были зафиксированы еe геометрические параметры.

Согласно паспорту деформации, высота деформированного участка составила 30 м при угле наклона $70^{\circ}$. Размеры обрушения составили: по фронту -

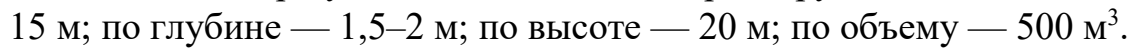

Для детального изучения деформированного участка уступа 9 июля 2015 г. проведено его георадиолокационное обследование. Целью работ являлось изучение структурных особенностей массива пород деформированного участка и выявление геометрических параметров скрытых структурных неоднородностей в зоне деформированных пород.

Продольные и поперечные профили производились в пределах заранее расчищенной от камней площадки. Начало и конец площадки находились непосредственно над заколом и совпадали с его началом и окончанием. Расчищенная площадка не захватывала массив пород за заколом (слева и справа) и была ограничена его шириной. Общий вид расчищенной площадки и ее геометрические параметры представлены на рис. 1.17.

На рис. 1.18 представлена схема профилирования по поверхности уступа +70 м (непосредственно над заколом), где стрелками указано направление профилей. Профили, сделанные по откосу уступа, имеют направление снизувверх, начало и конец профиля согласно схеме (рис. 1.19). На рис. 1.19 представлена схема профилирования откоса уступа.

Для определения геометрических параметров структурной неоднородности, по которой произошло обрушение, было проведено георадарное профилирование в продольном направлении по заранее расчищенному коридору длиной 30 м по двум параллельным профилям (по двум сторонам расчищенного коридора) на радарограммах (рис. 1.20). Также в пределах расчищенного участка 
были выполнены пять поперечных профилей пересекающих продольные на отметках 5, 9, 11, 16 и 21 м. Один из поперечных профилей представлен на радарограмме (рис. 1.21) направлением от стенки уступа к кромке.

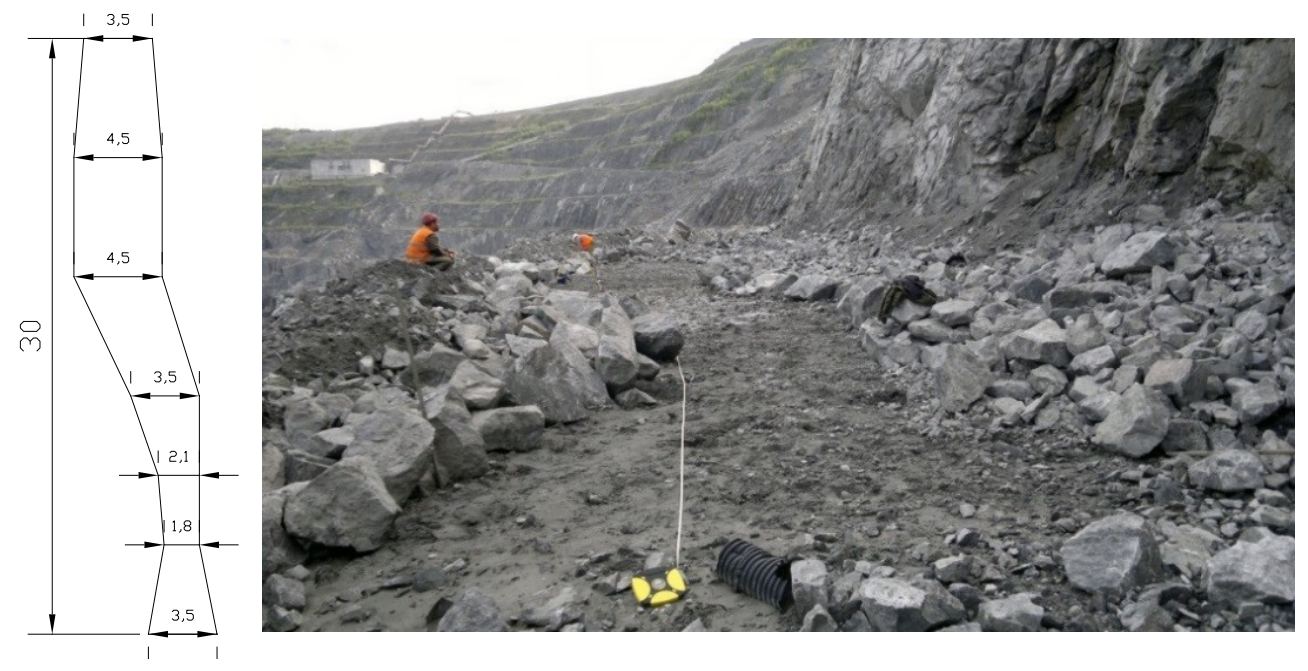

Pис. 1.17. Общий вид и геометрия площадки проведения георадарного обследования

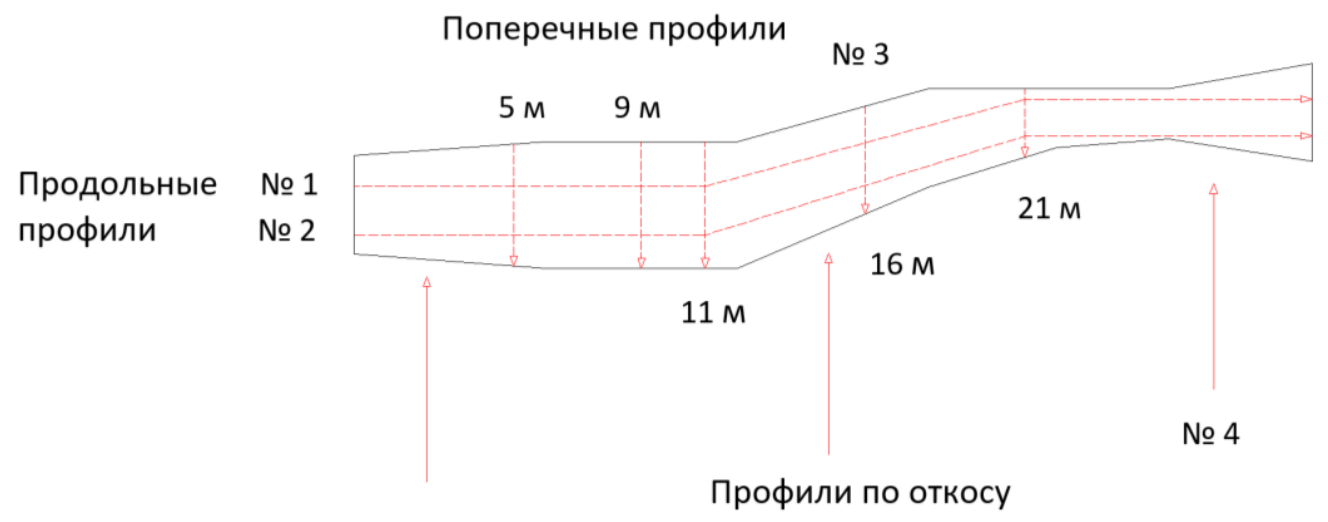

Рис. 1.18. Схема профилирования участка уступа

В результате камеральной обработки и интерпретации радарограммы (рис. $1.20, a)$ выявлена подповерхностная граница (красная сплошная линия), предположительно верхняя граница закола, глубина залегания которой изменяется от 5,5 м в начале профиля до 5 м, на отрезке 9-13 м длины профиля, и до глубины 6 м на отрезке 19-27 м длины профиля.

В результате камеральной обработки и интерпретации радарограммы (рис. 1.20, б) выявлена подповерхностная граница (красная сплошная линия), предположительно верхняя граница закола, глубина залегания которой изменяется от 6 м в начале профиля до 5,5 м, на 9 м длины профиля и до глубины 6,5 м на отрезке 17-28 м длины профиля. 


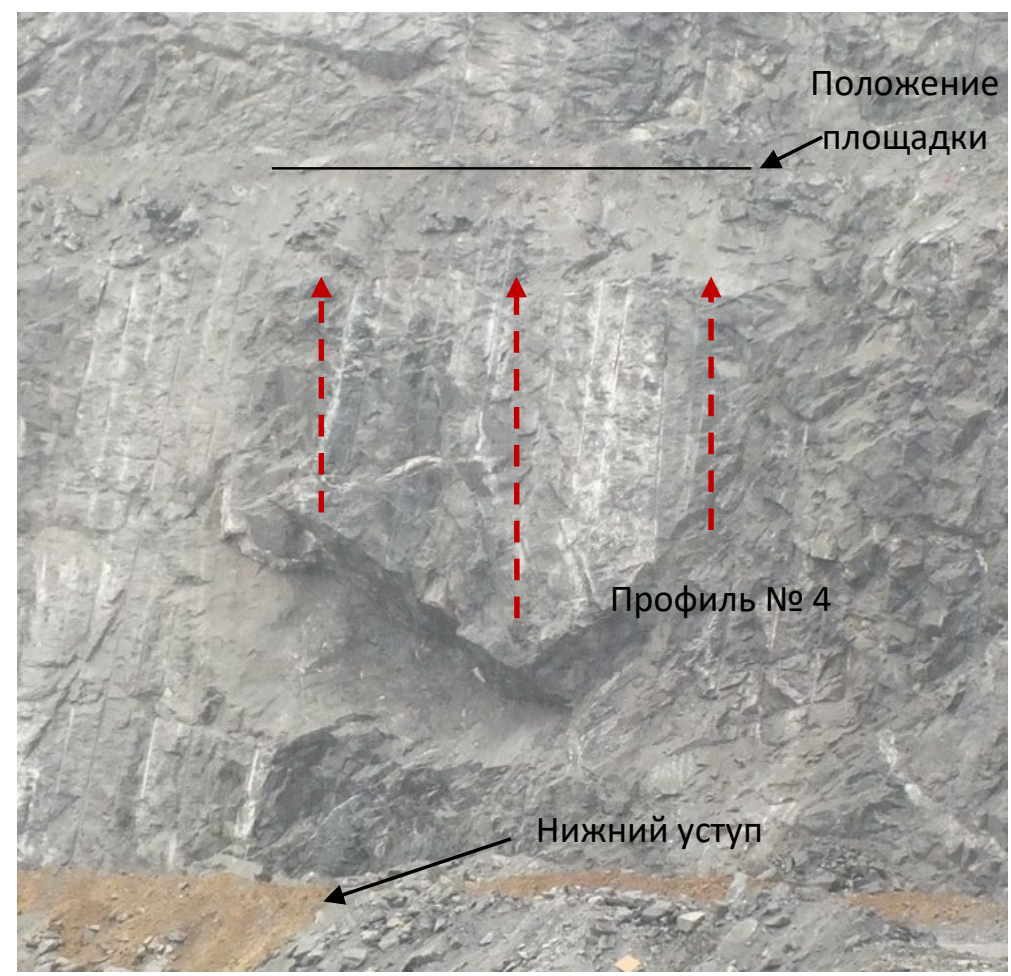

Рис. 1.19. Схема профилирования откоса уступа

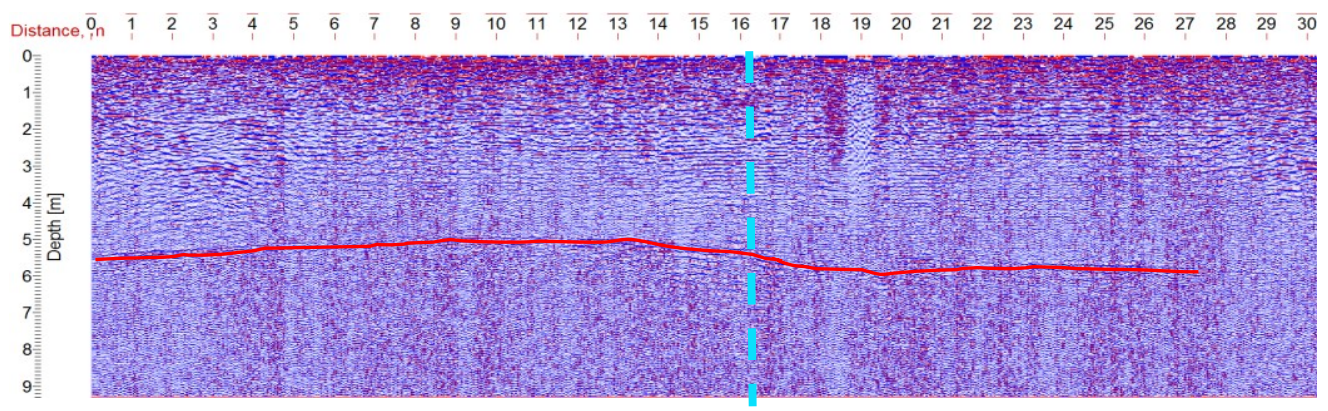

a

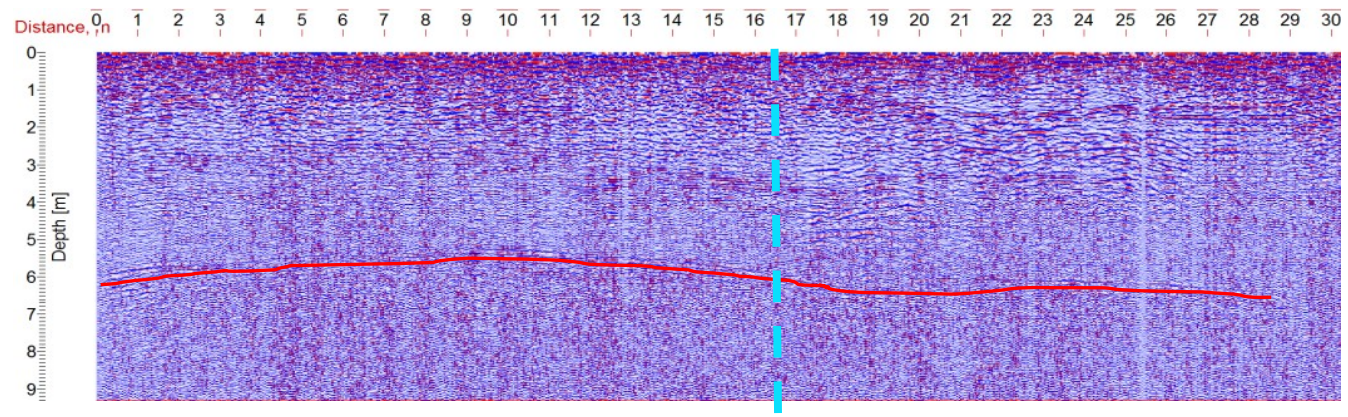

$\sigma$

Рис. 1.20. Радарограмма по профилям № 1 (a) и № 2 (б). Пунктирная голубая линия на радарограмме - пересечение с поперечным профилем № 3 


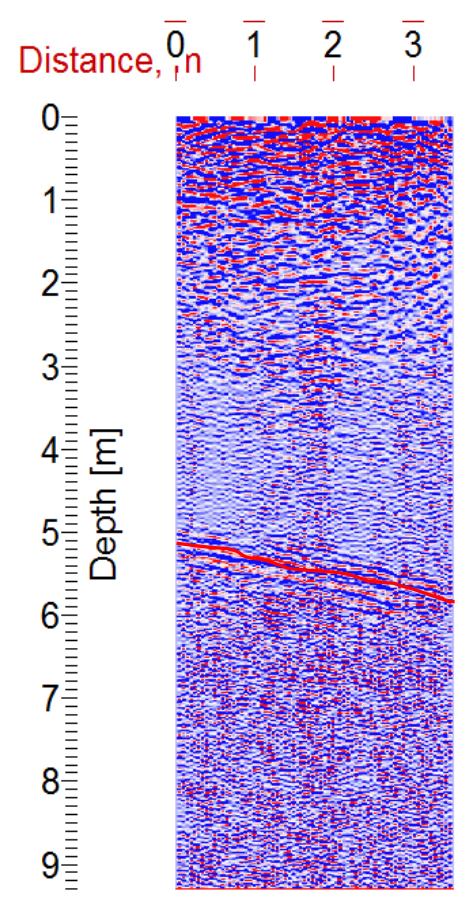

Рис. 1.21. Радарограмма по профилю № 3 (согласно схеме)
В результате камеральной обработки и интерпретации радарограммы (рис. 1.21) выявлена подповерхностная граница (красная сплошная линия), предположительно, верхняя граница закола, которая плавно увеличивается вглубь массива, глубина залегания которой колеблется от 5 м в начале профиля до 6 м в конце профиля.

Для уточнения геометрических параметров структурной неоднородности в зоне деформаций (рис. 1.22) при участии профессиональных альпинистов компании «Геополимер» было произведено георадарное профилирование по субвертикальному откосу деформированного уступа.

Радарограмма по профилю № 4 (рис. 1.23) (согласно схеме), где по шкале $X$ расстояние по откосу (начало, конец и направление профиля согласно схеме рис. 1.19), а по шкале $Y$ расстояние от откоса вглубь массива.

В результате камеральной обработки и интерпретации радарограммы в конце профиля на отметке 7,3 м выявлена подповерхностная граница (красная пунктирная линия), предположительно часть верхней границы закола, черной пунктирной линией обозначена зона неоднородности (трещиноватости) отличающаяся по физико-механическим характеристикам от окружающих пород и имеющая сложную геометрическую форму, залегающая от поверхности на глубину от 3 до 6 м.
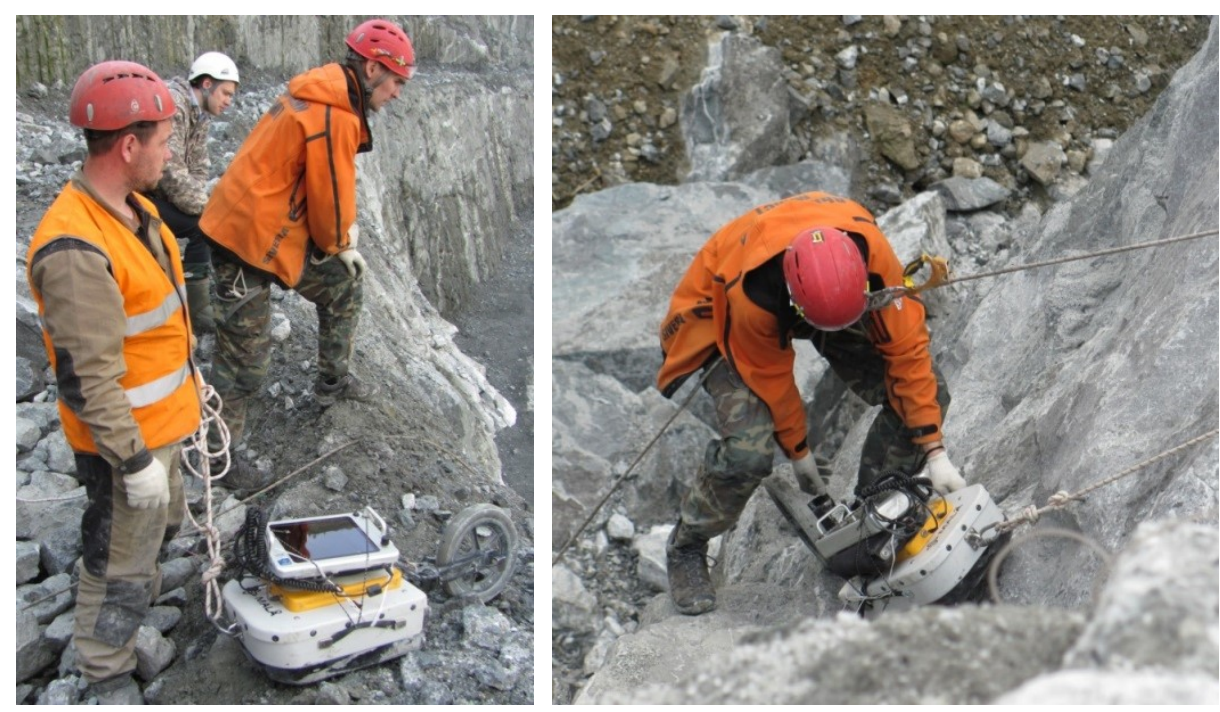

Рис. 1.22. Георадарное обследование по откосу уступа 
При обследовании откоса уступа на профилях, выполненных по левой части деформации и ее середине, не представляется возможным выделение структурных неоднородностей ввиду наличия большого количества помех на радарограммах, что являлось следствием невозможности соблюдения методик проведения георадиолокационного обследования (неровность поверхности, отсутствие постоянного контакта антенны с массивом пород, отсутствие срабатывания одометра во время перемещения георадарного комплекса).

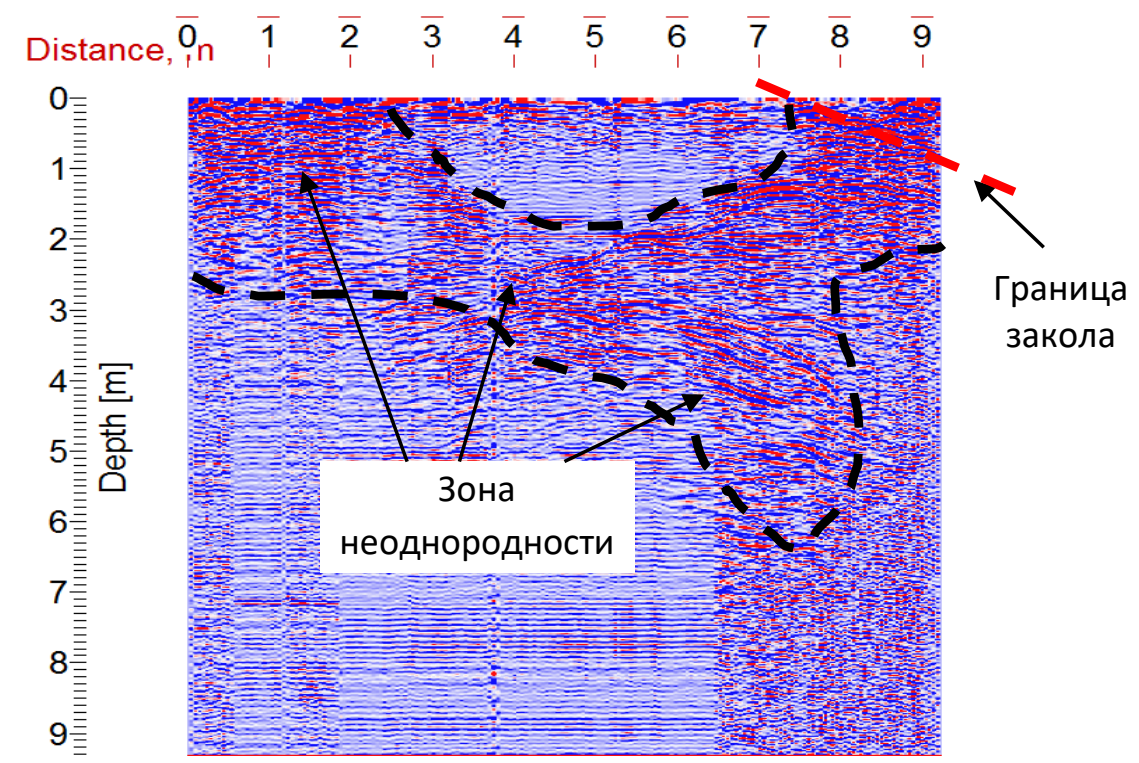

Рис. 1.23. Профиль № 4 по откосу уступа

По результатам продольного и поперечного профилирования участка деформационного уступа выявлена граница с глубиной залегания от 5 до 6,5 м предположительно, интерпретирована как верхняя граница закола на этом участке, которая плавно увеличивается вглубь массива. Расчищенный коридор на обследуемой площадке совпадает с проекцией закола и не захватывает левую и правую части массива за заколом. В пределах коридора границ, свидетельствующих о сужении закола, не выявлено, вследствие чего можно предполагать о существенном расширении закола вглубь массива. 


\section{2. МОДЕЛИРОВАНИЕ ЭЛЕКТРОМАГНИТНОГО ПОЛЯ, ИНДУЦИРОВАННОГО ГЕОРАДАРНЫМ ЗОНДИРОВАНИЕМ В СКАЛЬНЫХ ПОРОДАХ}

\section{1. Теоретические основы}

Трещиноватость скального массива (ориентировка, частота, тип и вид трещин) оказывает существенное влияние на формирование состояния и иерархично-блочной структуры скальных пород, что, в свою очередь, определяет устойчивость обнажений при ведении открытых горных работ $[43,44]$.

Исследование взаимосвязи волновых характеристик электромагнитного сигнала с состоянием трещиноватого массива скальных пород позволяет получить основу для количественной интерпретации данных георадиолокации, и анализа волновых картин радарограмм для выделения неоднородностей: зон трещиноватости - полости различной формы и их заполнение (воздух, вода), видоизмененные породы и т. п.

В подповерхностной георадиолокации распространение электромагнитных волн метрового и дециметрового диапазона в геологической среде-диэлектрике описывается уравнениями Максвелла [36]:

$$
\nabla^{2} \vec{E}-\frac{\varepsilon \partial \vec{E}}{c^{2} \partial t^{2}}-\mu_{0} \sigma \frac{\partial \vec{E}}{\partial t}=0
$$

где $\vec{E}-$ напряженность электрического поля (B/м); $\varepsilon-$ действительная часть комплексной относительной диэлектрической проницаемости (безразмерная величина); $c$ - скорость распространения электромагнитной волны в пространстве (м/с); $\mu_{0}$ - магнитная проницаемость среды (Г/м); $\sigma$ - проводимость (См/м).

На входе среды источником генерируется электромагнитный импульс, на выходе - приемной антенной воспринимается отклик среды - совокупность волн, отличающихся друг от друга временами пробега, интенсивностью и формой. В кинематических и динамических характеристиках этих волн и содержится информация о среде. Для георадиолокации - это двойные времена пробега электромагнитных волн до границы раздела сред с различной диэлектрической проницаемостью, информация о потерях, связанных с токами проводимости, информация о дисперсии фазовых скоростей в среде [35, 36].

В данной главе рассматривается моделирование электромагнитного поля, индуцированного георадарным зондированием в скальных породах, включающих основные типы неоднородностей, для понимания механизма формирования особенностей волновых характеристик сигнала, наблюдаемых на экспериментальных радарограммах.

Для выявления влияния на состояние массива пород нарушений крупного порядка, которые, в свою очередь, влияют на процессы ведения горных работ, сдвижение, обвалы и другие проявления горного давления, выполнено моделирование работы георадара на участке карьера с горизонтальной, 
наклонной и вертикальной разломной структурой. Расчеты выполнены методом конечных разностей во временной области с использованием программы MATGPR [45-50].

\section{2. Горизонтальная структурная неоднородность}

Развитие информационных технологий в последнее десятилетие подвигло большое количество специалистов-теоретиков в области георадиолокации на создание различных проектов по решению задач георадиолокации, например, MatGPR и GPRMAX. Одним из методов расчета является конечно-разностное моделирование, основанное на решении уравнений Максвелла.

Конечно-разностный подход к моделированию заключается в дискретизации времени и пространства: решение ищется по сетке, состоящей из прямоугольных ячеек с заданным шагом по времени. Вначале задается функция источника, свойства среды и граничные условия (обычно поле равно нулю на бесконечности или на границах). Исходя из этих условий значение поля известно в начальный момент времени $t_{0}$ в источнике. В следующий момент времени $\left(t_{0}+\Delta t\right)$ значения векторов электрической и магнитной напряженностей вычисляются в соседних ячейках и т. д. Интерактивный процесс продолжается, пока поле не достигнет границ модели или границ рассчитываемой радарограммы. В отличие от лучевого моделирования, при конечно-разностном поиск решения выполняется не только для дальней зоны, но и для ближней и переходной. Для расчета радарограмм в основном используют двухмерное приближение, как более быстрое. Трехмерное моделирование применяют, когда надо предсказать диаграмму направленности антенны в сложных случаях дисперсионной среды, нахождения границы или объекта в ближней или переходной зоне [38].

На рис. 2.1, $a-e$, представлены схема, модель и результаты компьютерного моделирования электромагнитного поля, индуцированного георадарным зондированием (имитация работы георадара с антенной 100 МГц), в скальном массиве, включающем горизонтальную структурную неоднородность. В левой части рис. 2.1, $a$ (фото), показан пример типичной горизонтальной структурной неоднородности, которая часто встречается на уступах карьера в различных вариациях. Геометрическая схема модели среды скального участка рис. 2.1, б, представлена в виде вертикального разреза фрагмента уступа размером $20 \times 15$ м, с горизонтальной неоднородностью длиной 2 м и шириной (мощностью) 0,1 м.

При моделировании значение диэлектрической проницаемости вмещающих монолитных пород было принято равным 6, а структурной нарушенности, согласно справочным данным физических свойств горных пород [41] (в целях контрастности данных) в 2 раза больше - 12 .

Анализ необработанной модельной радарограммы (рис. 2.1, в) позволил выявить амплитудные изменения волновой формы сигнала, отраженного от левой и правой границы неоднородности. Образовалось два гиперболических отражения, не позволяющих определить истинные размеры неоднородности: левая и правая гиперболы пересеклись, вследствие чего создалась иллюзия отражения от верхней и нижней границ.

На рис. 2.1, 2, представлена волновая форма сигнала (георадиолокационная трасса), проходящего непосредственно посередине неоднородности, форма 
сигнала отвечает отражению непосредственно от неоднородности. Так как фронт волны распространения электромагнитной волны имеет сферическую форму, то локальные объекты, размеры которых сопоставимы или меньше длины волны в среде, будут являться точечными источниками вторичных волн. Такие объекты будут регистрироваться в виде гипербол, на рис. 2.1, $\partial$, зелеными стрелками указаны «хвосты» гипербол, плоские же отражающие поверхности, размеры которых больше длины волны, в среде будут сохранять свою форму на радарограммах.

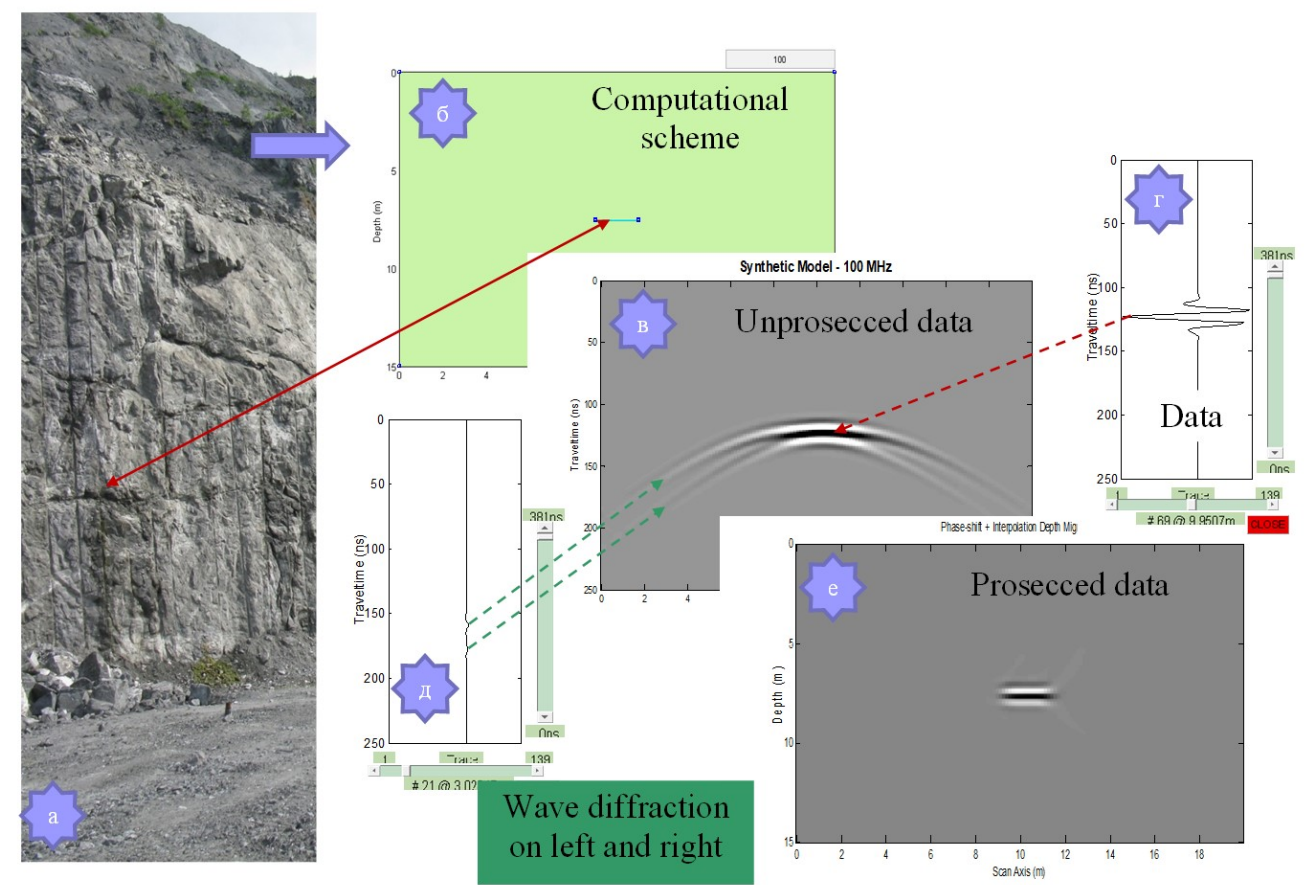

Рис. 2.1. Схема, модель и результаты моделирования электромагнитного поля, индуцируемого электромагнитным зондированием, в окрестности горизонтальной неоднородности: $a$ - неоднородность на уступе карьера; 6 - геометрическая схема модели; 6 - синтетическая модель радарограммы; $2, \partial-$ волновая форма сигнала в точке; $e-$ обработанная радарограмма

Для идентификации истинного положения объекта применена процедура миграции, которая заключается в том, чтобы все волны (невидимые на полевом материале) от элементарных источников просуммировать по своим гиперболическим осям синфазности, то есть собрать энергию колебаний в вершину гиперболы - истинное местоположение элементарного источника колебаний [36].

На рис. 2.1, е, представлена обработанная радарограмма, где радиообраз объекта в несколько раз превышает истинные размеры, что связано с использованием низкочастотной антенны 100 МГц и, соответственно, большой длиной волны. Для устранения этого эффекта применяется процедура деконволюции [36], которая служит для сжатия импульсов сигнала и повышения разрешающей способности. 
Моделирование этого участка с имитацией применения высокочастотной антенны 500 МГц позволило получить более контрастную картину, ввиду лучшей разрешающей способности антенны (рис. 2.2). Анализ волновой картины синтетической радарограммы позволил четко определить вершины гиперболических отражений, которые образовываются на концах неоднородности.
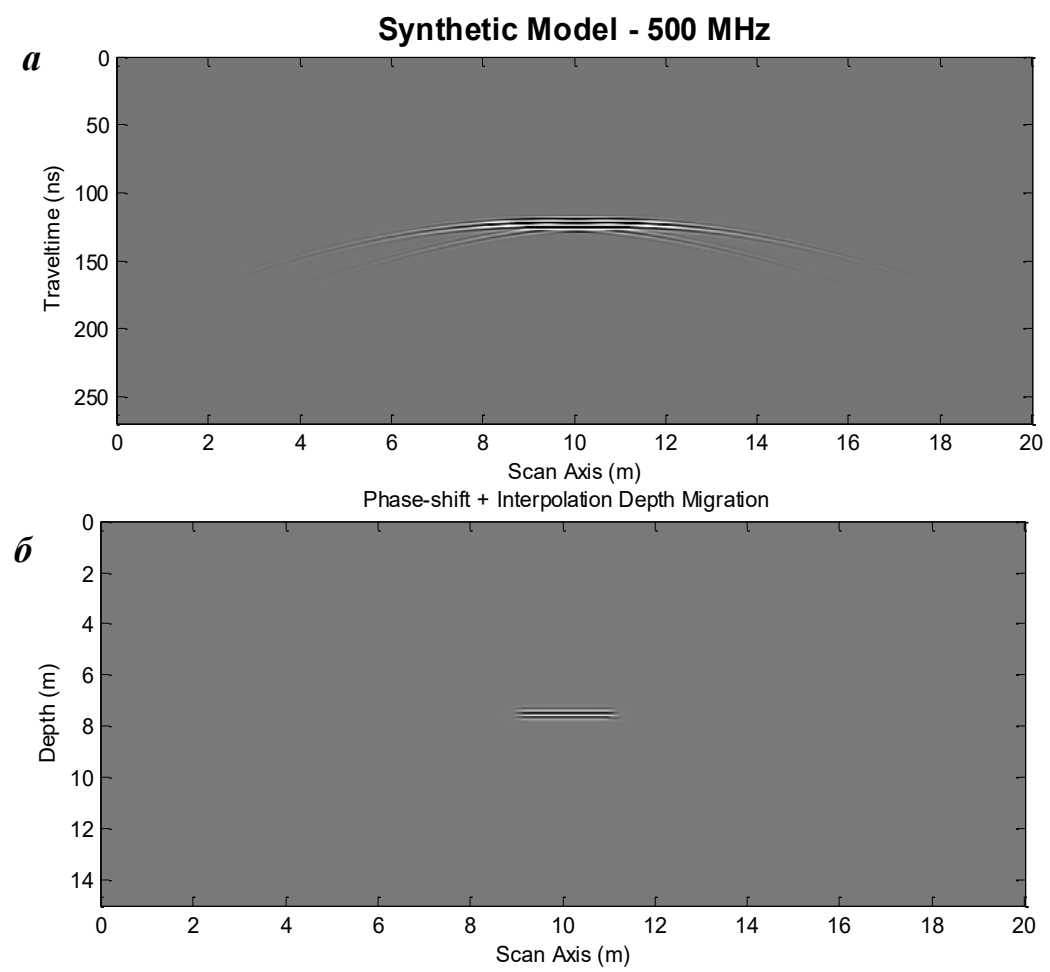

Рис. 2.2. Синтетическая радарограмма с использованием антенны 500 МГц: $a$ - необработанная; $\sigma-\mathrm{c}$ использованием процедур обработки

Таким образом, можно сделать вывод, что, приближаясь георадаром к горизонтальной неоднородности в массиве скальных пород, на получаемой на экране радарограмме заблаговременно проявляются отражения в виде «Хвостов» гипербол от углов неоднородности. При этом подтверждается, что, с повышением частоты антенны ухудшаются возможности обследования глубоких объектов, но в тоже время, повышается детальность их обследования.

Вместе с тем имитация применения георадара с антенной 800 МГц на этом участке показывает, что можно более четко определить верхнюю и нижнюю границу неоднородности, но с более слабыми, по сравнению с антеннами 100 и 500 МГц, амплитудными значениями (хвосты гипербол выражены в виде слабоамплитудных всплесков) (рис. 2.3). При моделировании этого участка антенной 100 МГц с линейно протяженной неоднородностью, где начало и конец находится вне зоны обследования, радиообраз будет выглядеть обычным горизонтальным отражением рис. 2.4, здесь отсутствуют вторичные волны, которые, как отмечалось выше, возникают и проявляются в виде гипербол от краев неоднородности, так называемый эффект дифракции. 


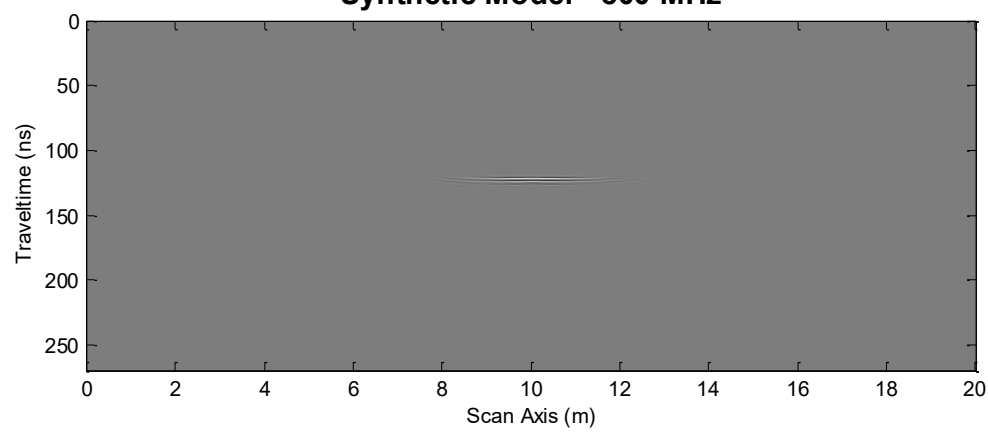

б

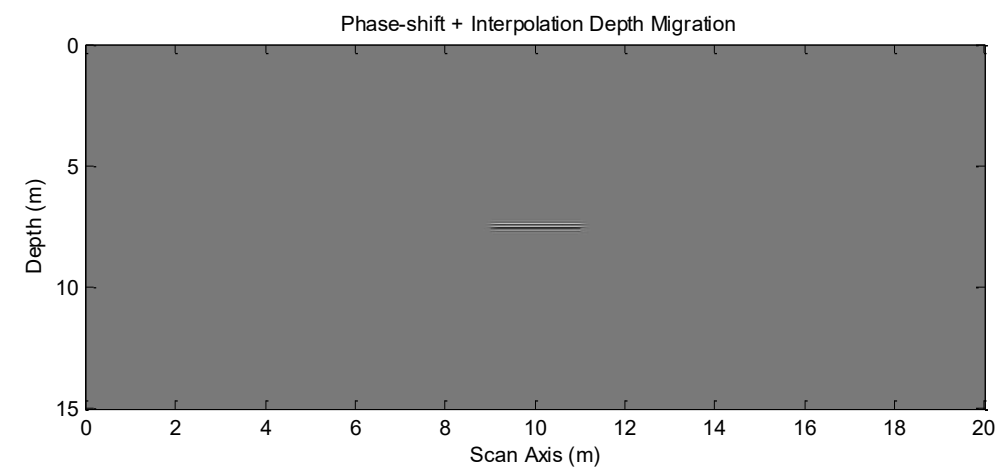

Рис. 2.3. Синтетическая радарограмма с использованием антенны 800 МГц: $a-$ необработанная; $\sigma-\mathrm{c}$ использованием процедур обработки

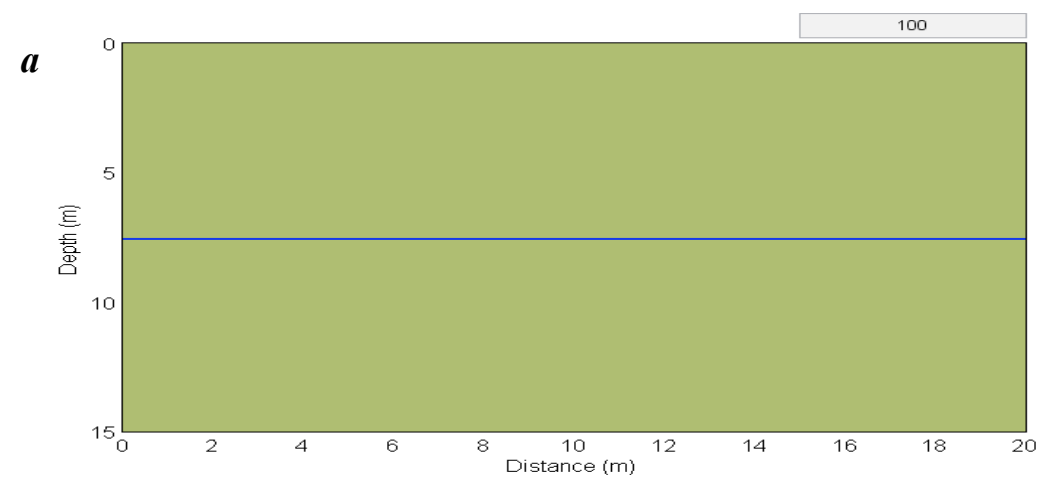

Synthetic Model - $100 \mathrm{MHz}$

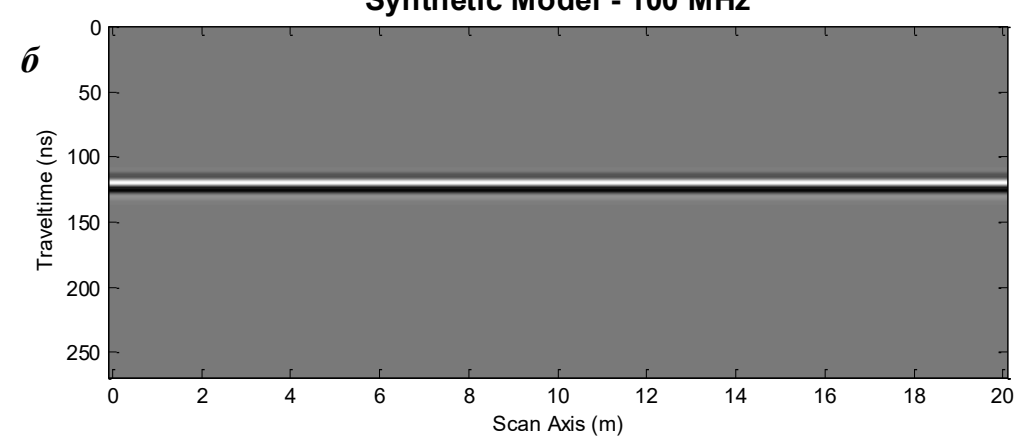

Рис. 2.4. Синтетическая обработанная радарограмма с использованием антенны 100 МГц: $a$ - геометрическая схема модели; $\sigma$ - с использованием процедур обработки 
Таким образом, установлена волновая картина осей синфазности и амплитудных характеристик сигнала радарограммы уступа, ослабленного горизонтальной неоднородностью.

\section{3. Наклонная структурная неоднородность}

На рис. 2.5, $a-e$, представлены схема, модель и результаты компьютерного моделирования имитации работы георадара над наклонной структурной неоднородностью скального массива, сориентированной под углом $45^{\circ}$ к нижней поверхности антенны 100 МГц. В левой части (рис. 2.5, $a$, фото) представлен пример типичной наклонной структурной неоднородности, которая часто встречается на уступах карьера.

Схема модели среды скального участка (рис. 2.5, б) представлена в виде вертикального разреза фрагмента уступа размером $20 \times 15$ м, с наклонной неоднородностью длиной 2 м и толщиной (мощностью) 0,1 м. Электрофизические свойства модели соответствуют тем же параметрам, что и для случая с горизонтальной неоднородностью. Анализ необработанной синтетической радарограммы (рис. 2.5, в) позволил выявить амплитудные изменения волновой формы сигнала, отраженного от неоднородности. При пересечении сигналом краев неоднородности, как и в случае с горизонтальным ее расположением, образовались два гиперболических отражения, которые маскируют полезный сигнал.

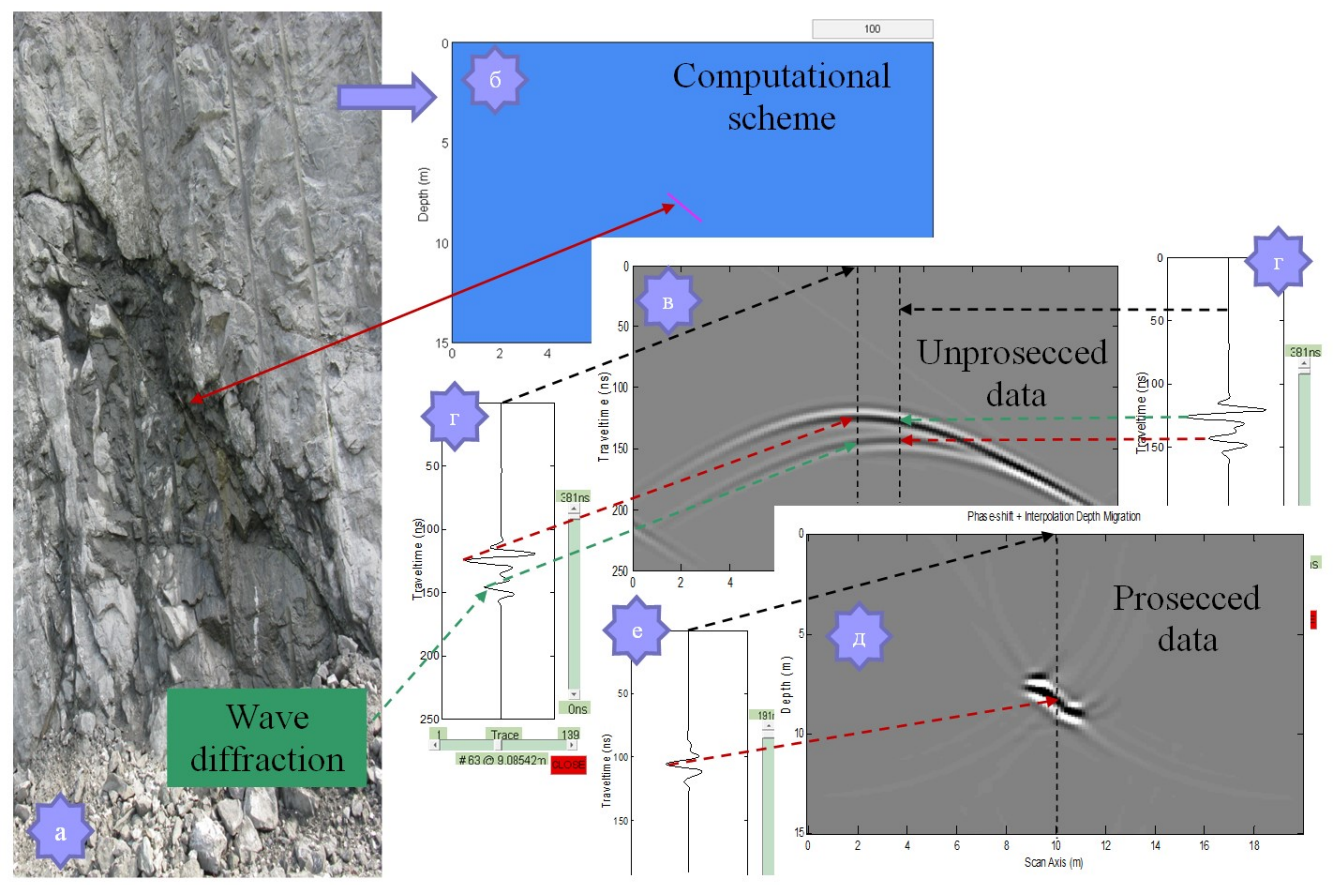

Рис. 2.5. Схема, модель и результаты моделирования электромагнитного поля, индуцируемого электромагнитным зондированием, в окрестности наклонной неоднородности: $a$ - неоднородность на уступе карьера, $\sigma$ - геометрическая схема модели, 6 - синтетическая модель радарограммы, г, e - волновая форма сигнала в точке, $\partial-$ обработанная радарограмма) 
Для восстановления истинного положения неоднородности была применена процедура миграции. На рис. $2.5, e$, представлена волновая форма сигнала (георадиолокационная трасса), проходящего непосредственно посередине неоднородности (рис. 2.5, ), которая содержит истинное отражение от объекта, в свою очередь, на рис. 2.5, г, тоже регистрируются объекты в виде гипербол, точечные источники вторичных волн, их «хвосты» обозначены зелеными и красными стрелками.

При моделировании этого участка, с имитацией георадарного зондирования антенной 100 МГц, с линейно протяженной неоднородностью, когда начало неоднородности выходит на дневную поверхность, а другой край находится вне зоны обследования, то радиообраз будет выглядеть наклонным отражением (рис. 2.6), с уменьшением амплитудных значений отражения по глубине.
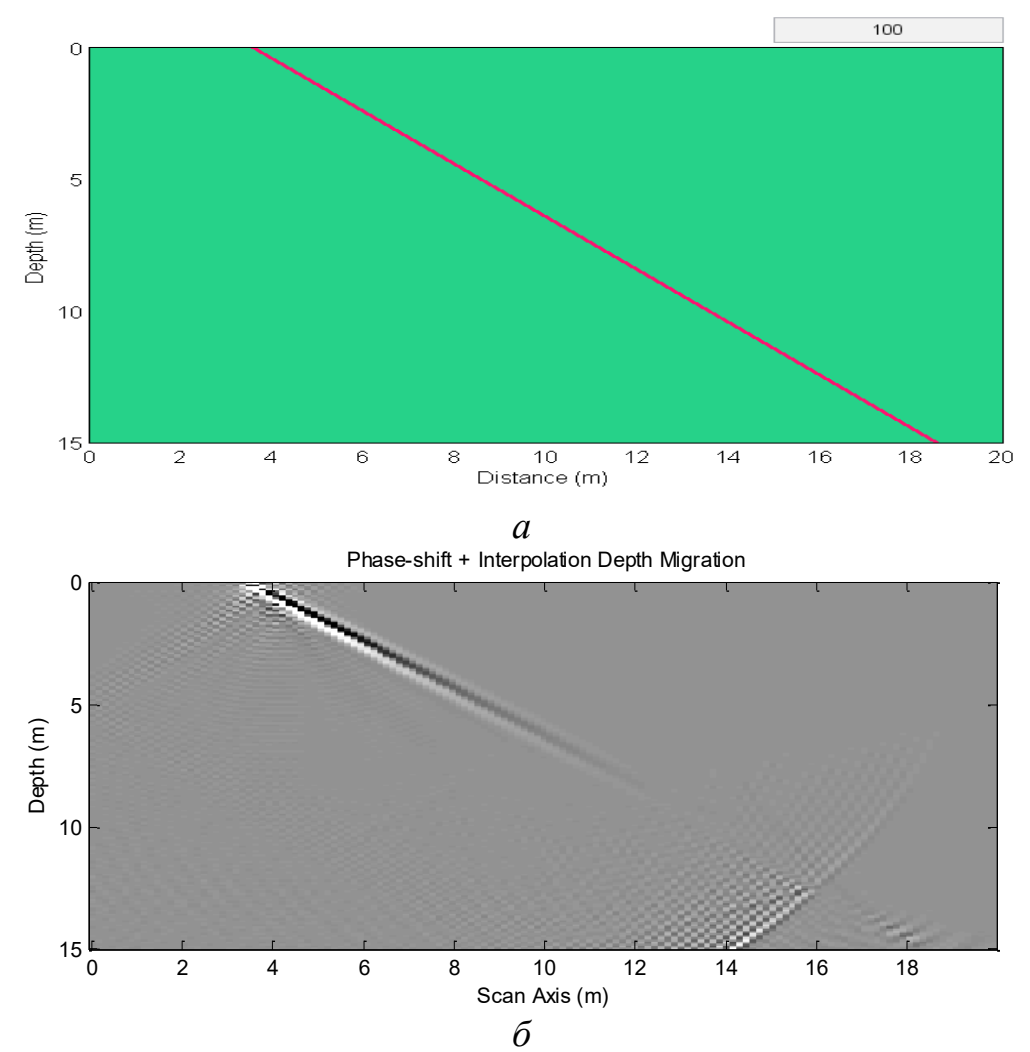

Рис. 2.6. Синтетическая обработанная радарограмма с использованием антенны 100 МГц: $a$ - геометрическая схема модели; 6 - с использованием процедур обработки

Таким образом, выявлена волновая картина осей синфазности и амплитудных характеристик георадиолокационного сигнала на радарограмме скального массива пород, ослабленного наклонной структурной неоднородностью.

\section{4. Вертикальная структурная неоднородность}

На рис. 2.7 представлены схема, модель и результаты компьютерного моделирования имитации работы георадара с антенной 100 МГц над вертикальной 
структурной неоднородностью скального массива пород. В левой части (рис. 2.7, a (фото)) представлен пример типичной вертикальной структурной неоднородности, достаточно широко распространенной и часто наблюдаемой на обнажениях пород на уступах карьера.

Схема модели среды скального участка (рис. 2.7, б) представлена в виде вертикального разреза фрагмента уступа размером $20 \times 15$ м с вертикальной неоднородностью длиной 2 м и толщиной (мощностью) 0,1 м. Электрофизические свойства модели соответствуют тем же параметрам, что и в предыдущих двух случаях.

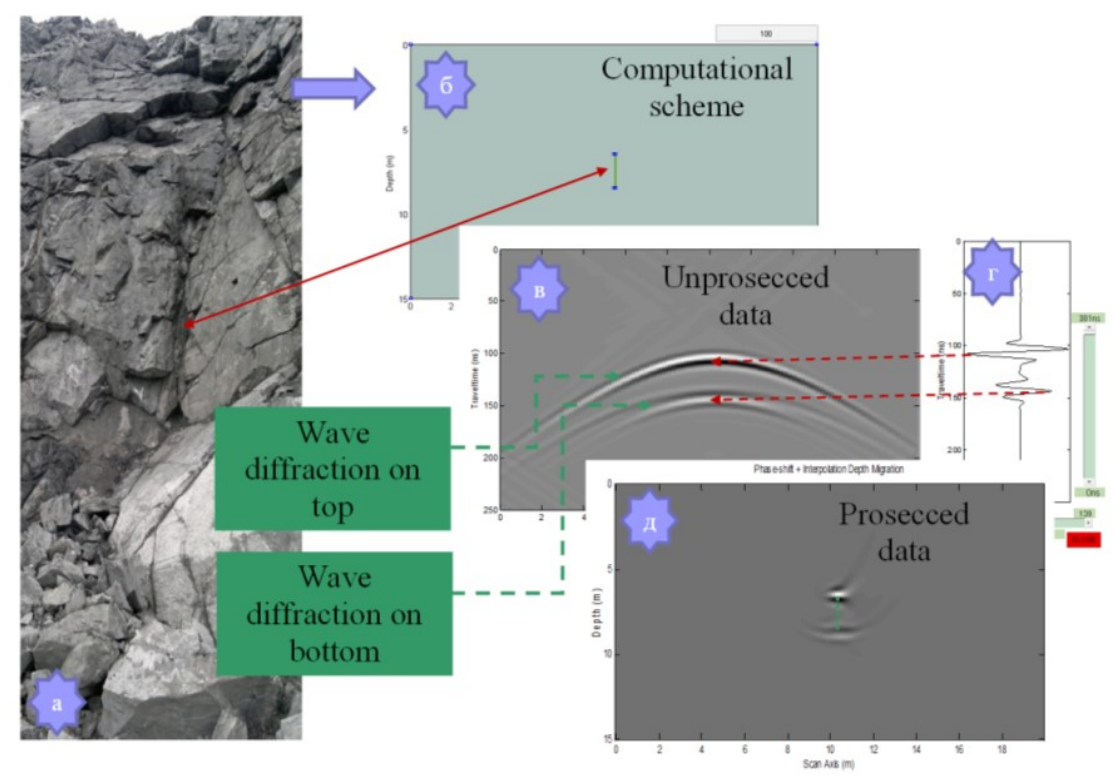

Рис. 2.7. Схема, модель и результаты моделирования электромагнитного поля, индуцируемого электромагнитным зондированием, в окрестности вертикальной неоднородности: $a$ - неоднородность на уступе карьера; 6 - геометрическая схема модели; 6 - синтетическая модель радарограммы, 2 - волновая форма сигнала в точке, $\partial$ - обработанная радарограмма

Анализ необработанной синтетической радарограммы (рис. 2.7, в) позволил выявить амплитудные изменения волновой формы сигнала, отраженной только от верхней и нижней границ (концов) неоднородности. При пересечении границ неоднородности так же, как и в случае горизонтальной неоднородности, образовались два гиперболических отражения, без отражений от остальной части неоднородности.

На рис. 2.7, 2, показана волновая форма сигнала (георадиолокационная трасса), проходящего непосредственно посередине неоднородности. Как можно видеть, форма сигнала содержит отражение только от концов неоднородности, т. е. фактически определяются только ее начало и конец.

Разная фаза амплитудных всплесков сигнала обусловлена изменением диэлектрической проницаемости пород: в первом случае - переход волны из ненарушенного массива (меньшая диэлектрическая проницаемость - 6) в неоднородность (нарушенный массив с большей диэлектрической 
проницаемостью - 12), во втором, наоборот, переход из нарушенных пород в ненарушенные (скачкообразное изменение диэлектрической проницаемости от 12 до 6$)$.

Для восстановления истинного положения неоднородности была применена процедура миграции. На рис. 2.7, д, представлена обработанная радарограмма, на которой отчетливо виден фактический радиообраз, но при этом мы различаем только верхний и нижний концы неоднородности как отражения от локальных объектов. В целом это затрудняет достоверную интерпретацию вертикальных объектов, а в отдельных случаях и вовсе приводит к невозможности их идентификации.

Таким образом, в результате компьютерного моделирования имитации работы георадара установлена модельная волновая картина осей синфазности и амплитудных характеристик на радарограмме скальных пород, ослабленных вертикальной неоднородностью. Выявлено, что в случае приближения георадара к вертикальной неоднородности в массиве скальных пород на радарограмме заблаговременно проявляются отражения в виде «хвостов» гипербол от верхнего и нижнего концов неоднородности.

\section{5. Пример эмпирического трассирования структурной неоднородности}

В качестве примера идентификации структурной неоднородности в массиве скальных рассмотрим результаты георадиолокационного обследования одного из участков уступа горизонта +140 карьера «Железный» $\mathrm{AO}$ «Ковдорский ГОК». Применение описанных выше подходов к идентификации структурных нарушений в скальном массиве по волновым данным радарограмм посредством анализа осей синфазности сигналов позволило выявить наклонную структурную неоднородность в породах уступа.

На рис. 2.8 представлен фрагмент результата площадной съемки с выявленной наклонной неоднородностью. Идентификация неоднородности производилась посредством анализа волновой картины и сопоставления осей синфазности сигналов.

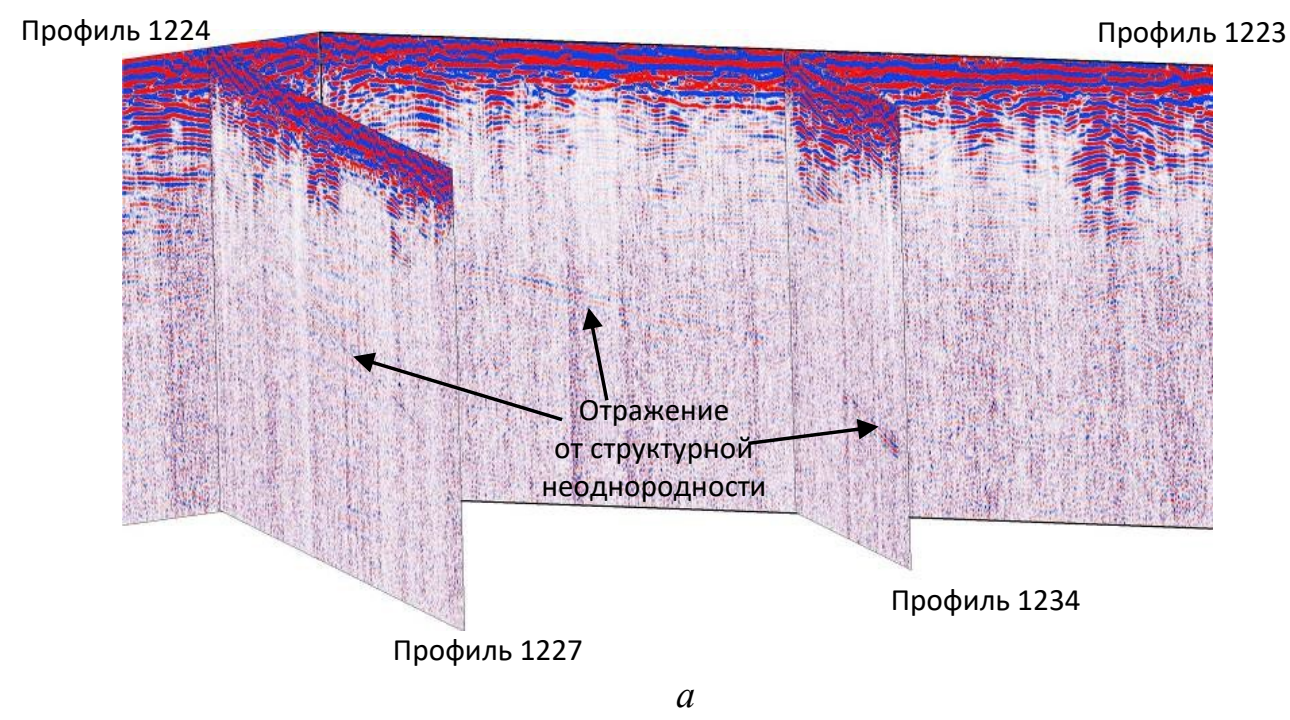




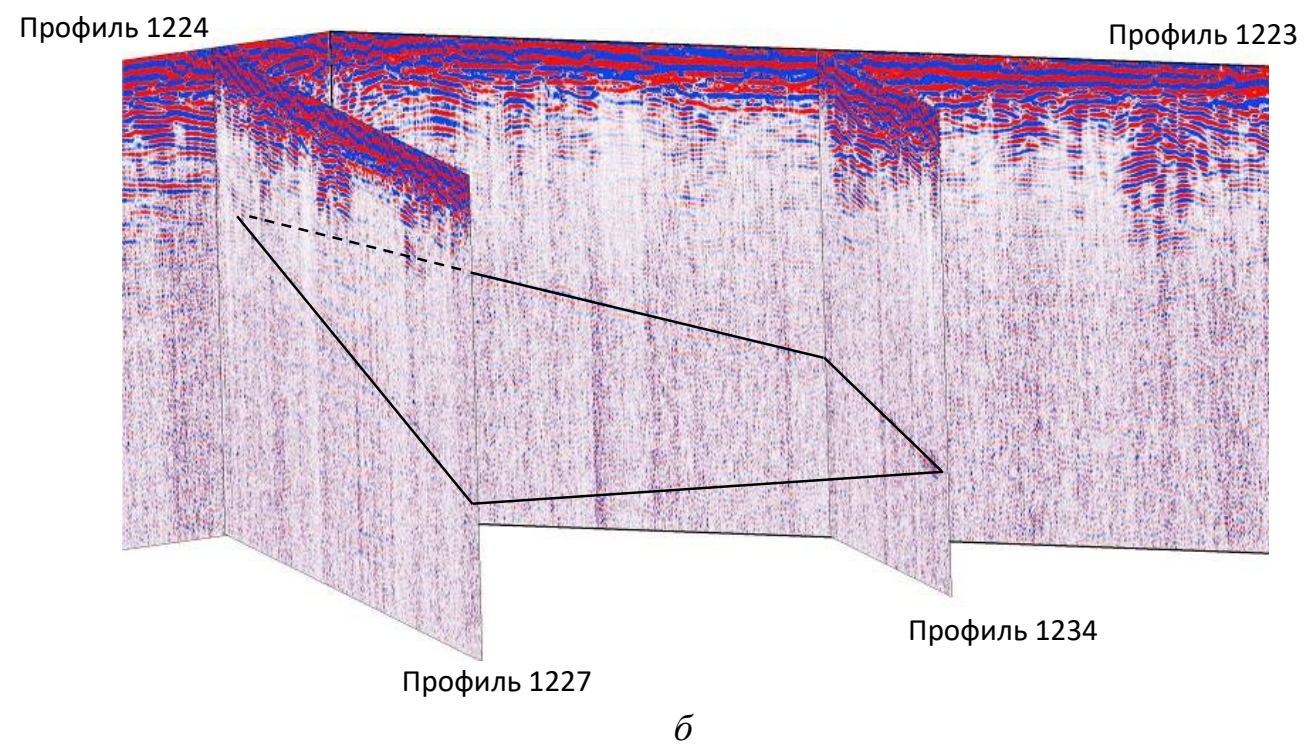

Рис. 2.8. Фрагмент результата площадной съемки на отобранных радарограммах:

$a$ - с пространственной привязкой, для трассирования структурной неоднородности; $\sigma$ - выделение структурной неоднородности

На отобранных радарограммах с пространственной их привязкой четко прослеживается отражение от структурной неоднородности (рис. 2.8, a). Картирование неоднородности сеткой профилей с интервалом в 1 м позволило определить ее положение в плане и по глубине (рис. 2.8, б).

Для трассирования плоскости структурной неоднородности была построена 3D-модель участка восточного борта карьера (рис. 2.9).

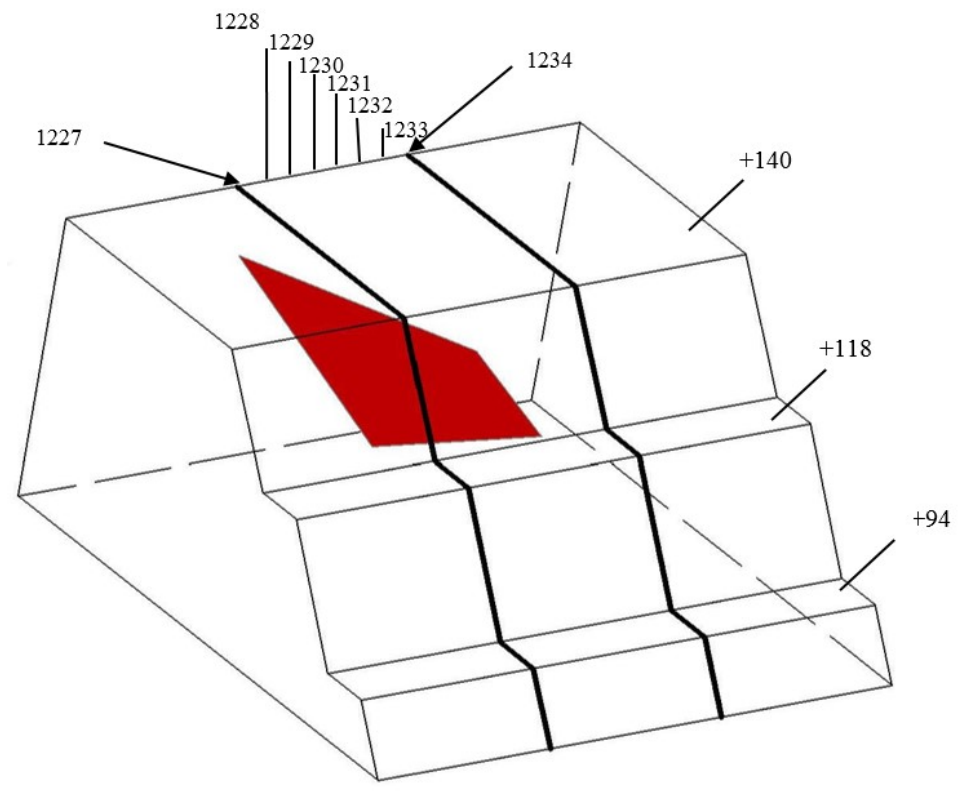

Рис. 2.9. 3D-модель участка восточного борта карьера с трассированием плоскости структурной неоднородности 


\section{3. ИЗМЕНЧИВОСТЬ ЭЛЕКТРОФИЗИЧЕСКИХ СВОЙСТВ НАРУШЕННЫХ И НЕНАРУШЕННЫХ СКАЛЬНЫХ ПОРОД}

Как отмечалось ранее, наиболее важными параметрами, характеризующими возможности применения метода георадиолокации в различных средах, являются удельное затухание и скорость распространения электромагнитных волн в среде, которые определяются ее электрическими свойствами. Первый из них определяет глубинность зондирования, знание второго параметра необходимо для пересчета временной задержки отраженного импульса в глубину до отражающей границы $[39,51]$.

Основным физическим свойством, которое можно определить при помощи георадиолокации, является диэлектрическая проницаемость пород, которая напрямую влияет на скорость распространения электромагнитных волн в среде. Породы являются весьма сложными природными многофазными образованиями, состоящими из различных по своим свойствам компонентов, находящихся в разном фазовом состоянии (твердом, идеально пластичном, жидком, газообразном), взаимно между собой связанных; они могут рассматриваться как однокомпонентные (сплошные) тела лишь при определенных условиях. Основными параметрами электрических свойств горных пород, включая мерзлые, являются: удельное электрическое сопротивление (УЭС) $\rho$ или обратная величина - удельная электропроводность $\sigma=1 / \rho$, диэлектрическая проницаемость $\varepsilon$, коэффициент поляризуемости $\eta$ и др. Диэлектрическая проницаемость пород определяет их способность поляризоваться под воздействием переменного электромагнитного поля за счет упорядоченной ориентации имеющихся в породе связанных электрических зарядов [52]. Диэлектрическая проницаемость скальных пород зависит от диэлектрических свойств составляющих ее компонентов - минеральных частиц, воздуха, воды, льда. Таким образом, диэлектрическая проницаемость сухих пород определяется только их плотностью и диэлектрическими свойствами слагающих их минералов, а свойства влажных пород определяются количеством воды в породе [52].

\section{1. Георадарное исследование геологического строения рабочего уступа карьера}

Разработка глубоких горизонтов карьеров выдвигает особое требование к проведению БВР на рабочих уступах в целях обеспечения оптимального дробления пород. Затраты на проведение БВР, качество отбойки и дезинтеграции горных пород, а также производительность карьерного оборудования напрямую зависят от того, в какой степени параметры БВР соответствуют геологоструктурному строению уступа. Наличие в массиве горных пород различного рода структурных неоднородностей (зоны трещиноватости, обводнения, геологических включений, тектонических нарушений и т. п.) приводит к поглощению и рассеиванию энергии распространяющейся взрывной волны, в результате чего происходит неравномерное дробление горной массы. Дополнительные затраты на дробление негабаритов приводят к существенному удорожанию стоимости ведения горных работ. Поэтому важную роль, влияющую на качество взрывной отбойки, приобретает учет в паспортах БВР дифференцированного изменения параметров геолого-структурного строения 
уступа. За счет этого становится возможным подбор рациональных параметров буровых, взрывных и экскаваторных работ, оптимально учитывающих геологоструктурные особенности массива пород, которые должны обеспечивать максимально возможное равномерное дробление горной массы для последующих технологических этапов ее обработки.

В данной главе монографии рассмотрены возможности применения георадиолокационного обследования законтурного массива пород участков рабочих уступов карьера для оценки их геолого-структурного строения и дифференцирования по степени структурной нарушенности до проведения и при подготовке буровзрывных работ.

В качестве примера на рис. 3.1 представлен участок обследования крупных трещин (северо-западный борт, горизонт +120 м карьера «Железный» АО «Ковдорский ГОК»), проходящих через несколько уступов, в значениях диэлектрической проницаемости, отражающей состояние массива с сопоставлением визуального обследования. Результаты георадарного исследования геологоструктурного строения массива скальных пород вначале обрабатывались с использованием специализированных для данного вида исследований компьютерных программ (ГЕОРАДАР-ЭКСПЕРТ и RadExplorer), раздельно интерпретировались, а затем выполнялся комплексный анализ полученных данных в пространственно-глубинной взаимосвязи.

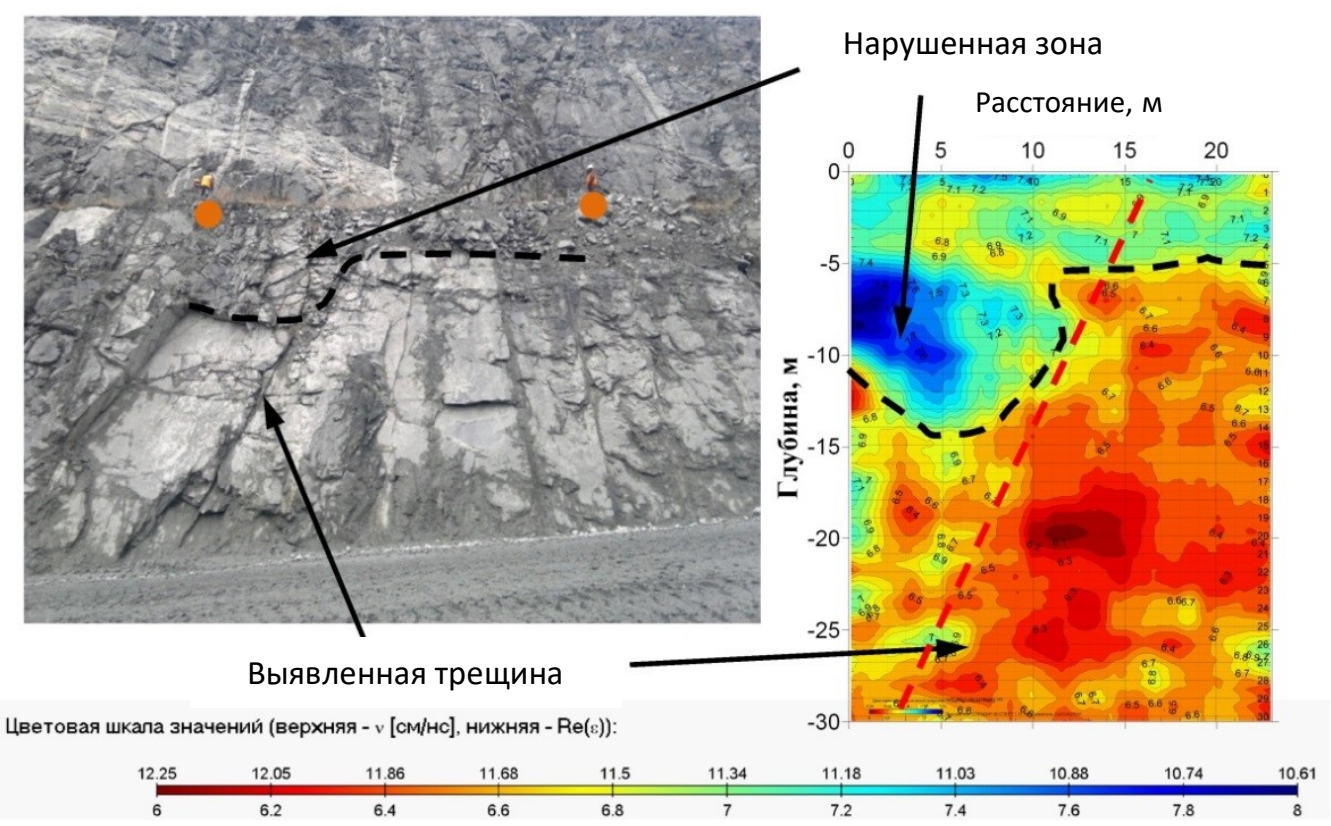

Рис. 3.1. Радарограмма и ее сопоставление с обнажением пород на уступе (начало и конец профиля обозначены на фото оранжевыми метками)

Для вычисления значений диэлектрической проницаемости использовалась программа автоматизированной обработки сигналов ГЕОРАДАРЭКСПЕРТ, где исходными данными служила числовая матрица амплитуд отраженных сигналов, полученная при электромагнитном зондировании. 
В результате вычислений на выходе формируется матрица того же размера, но уже со значениями диэлектрической проницаемости для каждой точки двумерного пространства разреза (технология основана на эффекте дифракции), что позволяет производить построение разрезов как в случае наличия отражающих границ, так и в случае непрерывного изменения электрофизических свойств по профилю наблюдений и по глубине [44]. Значения относительной диэлектрической проницаемости 6,5 были приняты соответствующими однородному состоянию скального массива $[41,44]$. Увеличение диэлектрических свойств пород до значения 8 в приповерхностной зоне объясняется еe повышенной нарушенностью, что подтверждается визуальным обследованием вертикального обнажения пород. Следовательно, возрастание значений диэлектрической проницаемости от 6,5 до и выше свидетельствует о большей степени неоднородности массива скальных пород.

Сопоставление значений диэлектрической проницаемости и локальных максимумов амплитуд огибающей электромагнитного сигнала (полученных в программе RadExplorer) по глубине представлено на рис. 3.2. Выявлено, что увеличение диэлектрической проницаемости соответствует высоким значениям локальных максимумов амплитуд огибающей электромагнитного сигнала и наоборот.

Комплексные исследования были проведены на участках рабочих уступов: западного (горизонт -35 м, запад, рис. 3.3), юго-западного (горизонт -110 м, юго-запад) и северного (горизонт -110 м, север) бортов карьера общей протяженностью около 4 км (190 радарограмм).

Георадиолокационные измерения выполнялись продольным и поперечным профилированием с использованием георадарного комплекса $\mathrm{RAMAC}$ по поверхности уступа до проведения работ и после бурения взрывных скважин, в комплексе с телеметрическим обследованием (с помощью телевизионной камеры) стенок скважин, созданием стоп-кадров и протоколированием визуально определяемых трещин и зон повышенной трещиноватости пород.

Горно-геологические условия исследуемых взрывных блоков: трещиноватости;

- горизонт -110 м, юго-запад, апатит-магнетитовая руда $\mathrm{V}$ категории

- горизонт -110 м, север, апатит-форстерит-магнетитовая руда, пироксениты V категории трещиноватости;

- горизонт -35 м, запад, ийолиты IV категории трещиноватости.

Обследуемые взрывные блоки являлись «сухими», на протяжении до 17-20 м глубины буровзрывных скважин вода отсутствовала.

Обработанные радарограммы до и после проведения буровых работ отличаются незначительно, ввиду использования низкочастотной антенны 100 МГц с глубиной зондирования до 30 м. Выявление дополнительно раскрытых трещин на малом расстоянии от скважины возможно использованием высокочастотных антенн от 1000 МГц с большей разрешающей способностью.

Геолого-структурная интерпретация заключалась в обнаружении и оконтуривании возможных зон трещиноватости по данным георадиолокации с заверкой этих данных телеметрическим обследованием, поэтому определение трещин проводилось только с точки зрения их наличия. 


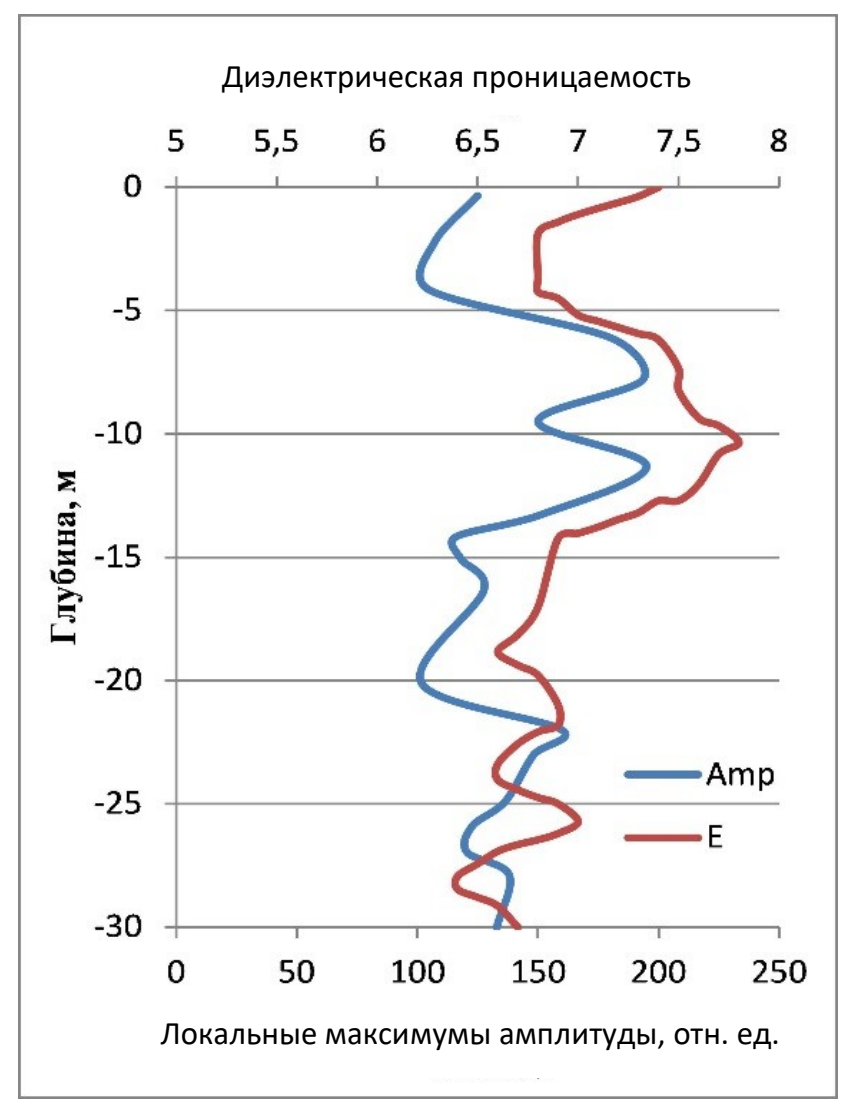

$a$

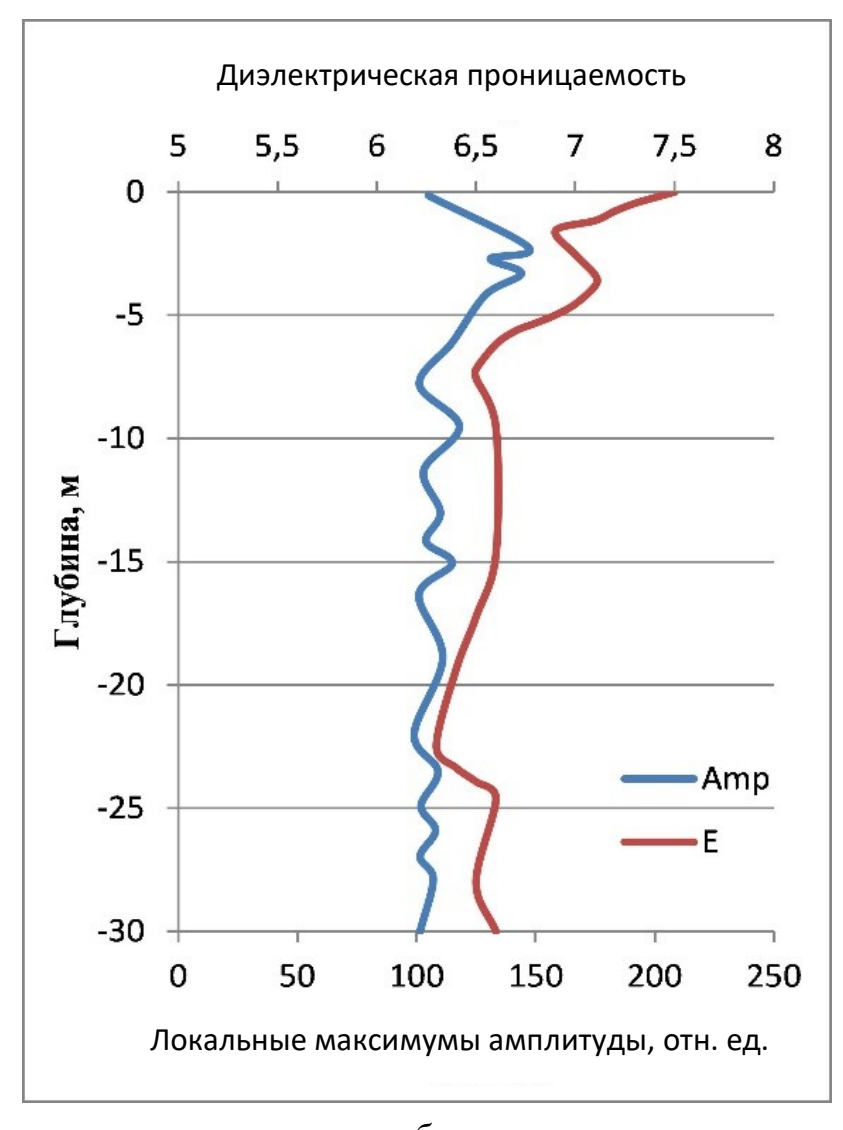

6

Рис. 3.2. Сопоставление значений диэлектрической проницаемости пород (Е) и локальных максимумов амплитуд (Атр) огибающей электромагнитного сигнала по данным натурных измерений: $a-5$-й метр профиля; $\sigma-20$-й метр профиля 


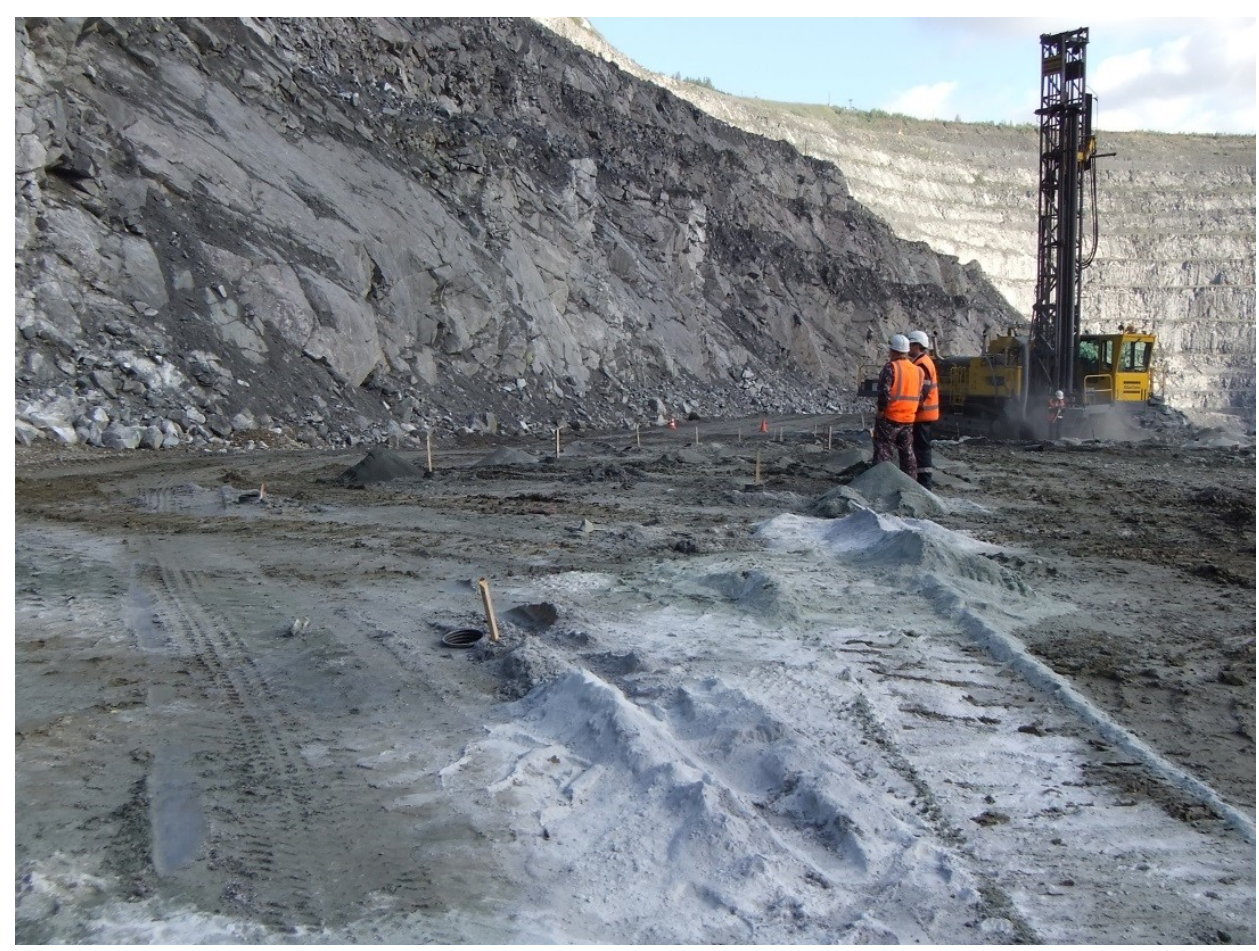

Рис. 3.3. Обследуемый георадиолокацией участок взрывного блока рабочего уступа рудника «Железный»

Очень часто на взрывном блоке, например, с $\mathrm{V}$ категорией трещиноватости по данным паспорта буровзрывных работ, встречаются зоны нарушенности с III или II категорией трещиноватости, которые влияют на качество раздробленной горной массы. Телеметрическим обследованием фиксировались закрытые типы трещин - разрывы сплошности горных пород, хорошо заметные, но с плотно прижатыми стенками. Выявлялись зоны трещиноватости - линейно вытянутый участок земной коры, в пределах которого трещины развиты более интенсивно, чем в окружающих породах.

Результаты комплексного исследования геолого-структурного строения уступа так же, как и в примере выше, обрабатывались с использованием специализированных для вида исследований компьютерных программ, интерпретировались раздельно, а затем выполнялся комплексный анализ полученных данных в пространственно-глубинной взаимосвязи.

Изменчивость свойств и неоднородность в массиве пород уступов карьера приводит к изменению параметров результирующего электромагнитного сигнала. Проведенное георадиолокационное зондирование при подготовке буровзрывных работ на рабочих участках уступов после бурения взрывных скважин, в комплексе с телеметрическим обследованием (с помощью телевизионной камеры) стенок скважин, созданием стоп-кадров и протоколированием визуально определяемых трещин и зон повышенной трещиноватости пород, позволило выявить взаимосвязь интенсивности трещиноватости пород и их диэлектрической проницаемости. 
В частности, на рис. 3.4 приведены взаимоувязанные по глубине данные телеметрического обследования скважины № 118 (горизонт -35 м, запад): распределение числа трещин (на 1 м - как количественная характеристика интенсивности трещиноватости пород); радарограмма вертикального сечения, построенная в изолиниях диэлектрической проницаемости пород по данным георадиолокационного профилирования этого участка рабочего уступа протяженностью 25 м. Как видно из гистограммы в центральной части рис. 3.4, число трещин по глубине скважин изменяется от 2-4 на 1 пог. м (приповерхностная зона и породы на глубине около 10 м) до 5 и более на интервалах абсолютных отметок 98,5-102 и 106,5-109 м (глубина скважины 3,5-7 и 11,5-14 м от поверхности соответственно). На радарограмме (правая часть рис. 3.4) визуально для этих глубин выделяются зоны голубого и синего цвета, в пределах которых диэлектрическая проницаемость пород регистрируется в более высоких значениях - от 8,8 до 9,7, то есть большее количество трещин на 1 пог. м в массиве пород прямо коррелируется с повышенным значением диэлектрической проницаемости на радарограмме этого участка. Таким образом, можно предположить, что определяемые георадиолокационными измерениями значения диэлектрической проницаемости пород свыше 8,8 будут соответствовать породам повышенной трещиноватости.

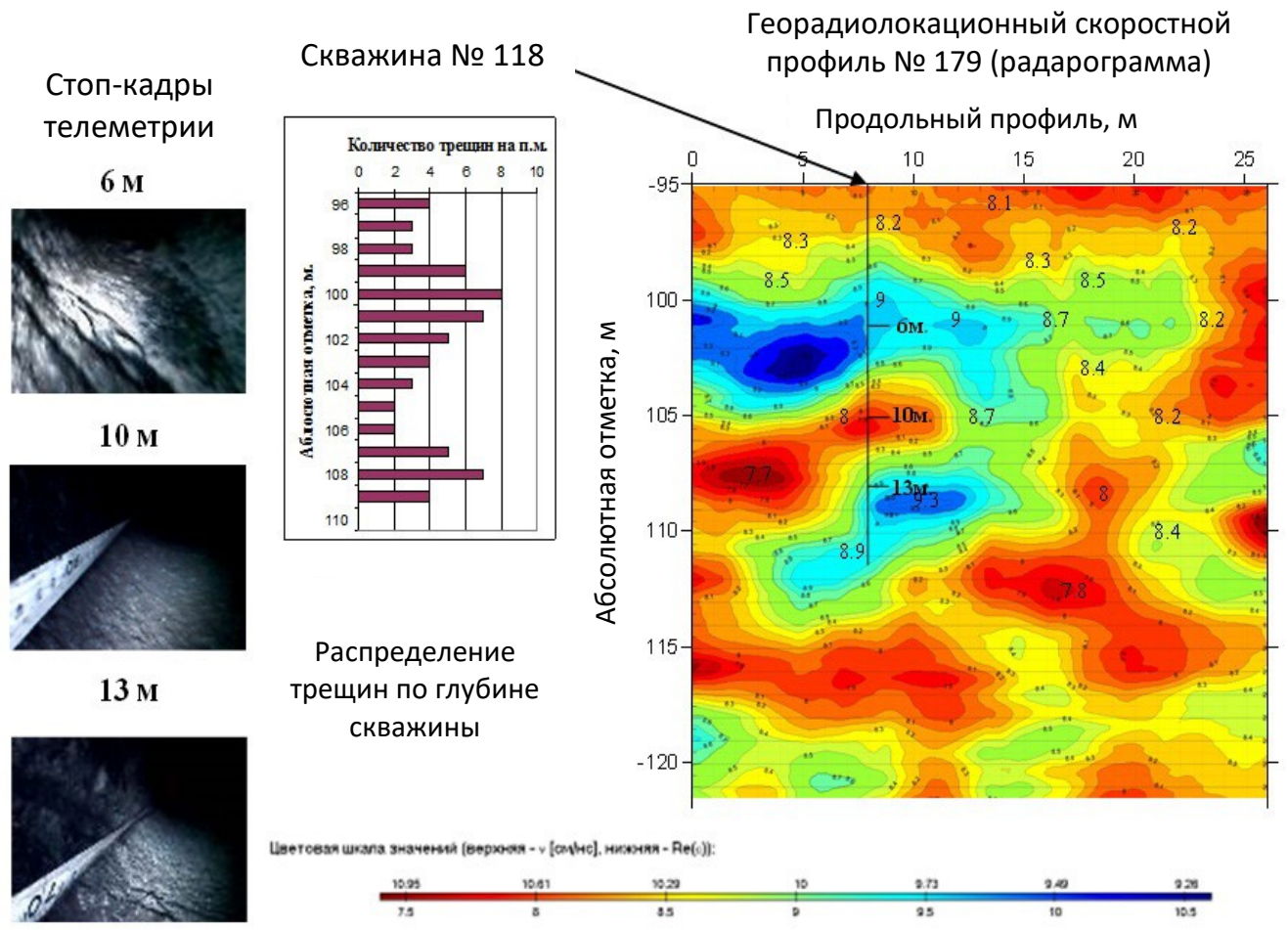

Рис. 3.4. Данные комплексных исследований взрывного блока рабочего уступа в пространственно-глубинной увязке (гор. -35 м, запад)

Вместе с тем, по данным георадарного зондирования, на радарограмме (проходящей по центру исследуемой площадки горизонт -110 м, север, рис. 3.5 ), в непосредственной близости от скважины № 60 выявлена зона повышенной 
трещиноватости на интервале 14-21 м со значениями диэлектрической проницаемости 9-9,3 и показателем абсолютной отметки 102-110 м (на глубине 9-17 м от поверхности уступа), которые подтверждаются данными телеметрического обследования скважины № 60 (рис. 3.6).

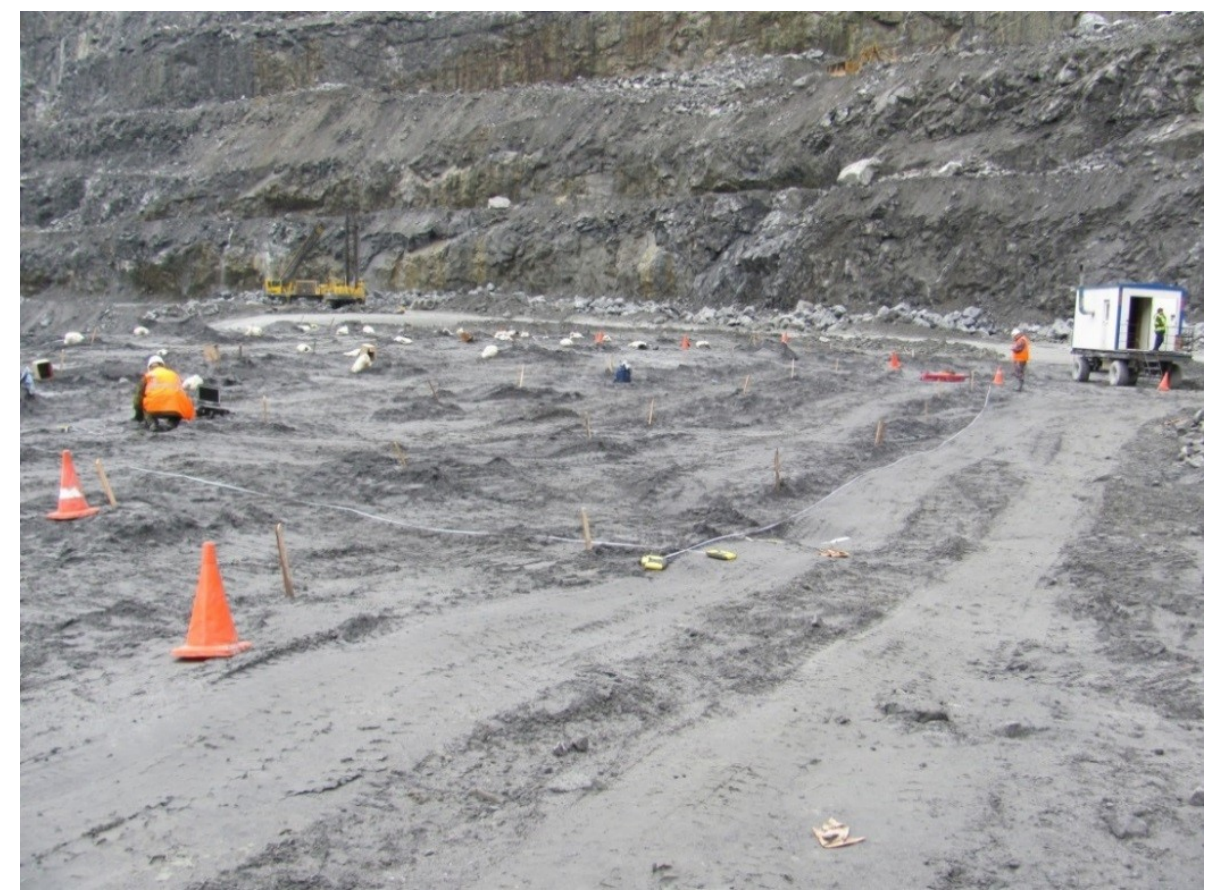

Рис. 3.5. Общий вид участка взрывного блока (гор. -110 м, юго-запад)

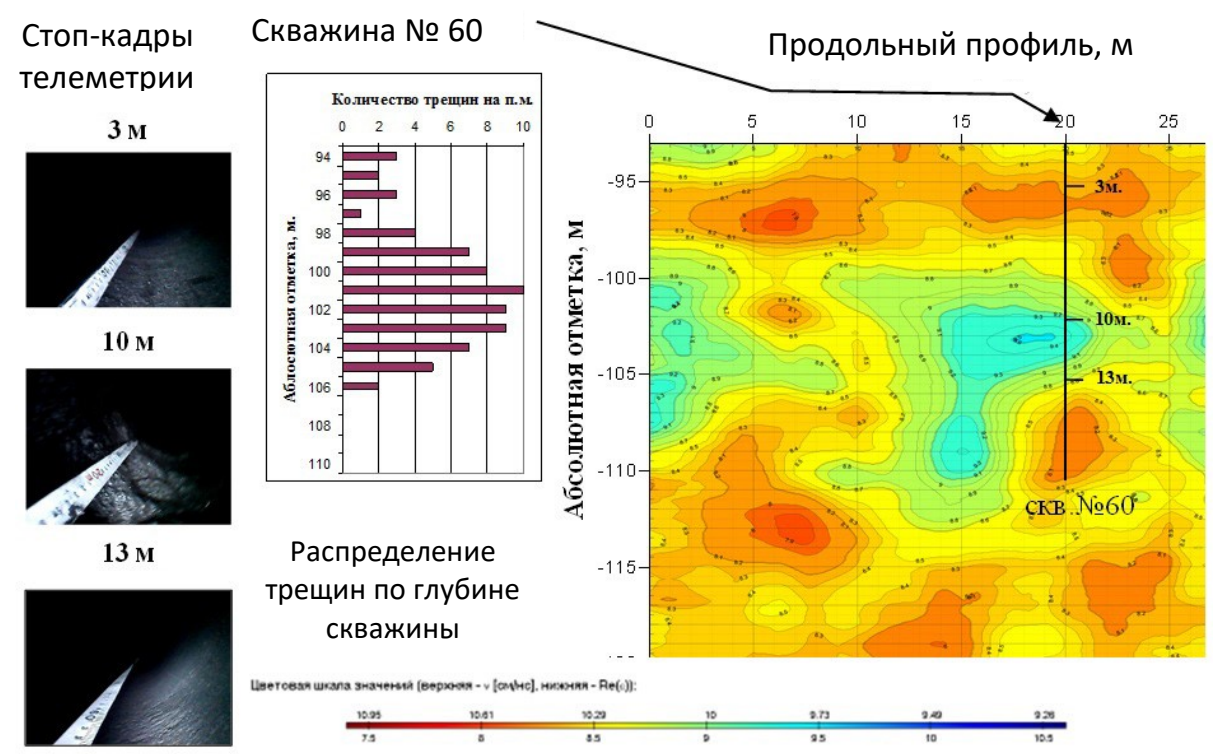

Рис. 3.6. Данные комплексных исследований взрывного блока рабочего уступа в пространственно-глубинной увязке (гор. -110 м, север) 
Как видно из рис. 3.6, радарограмма характеризуется неравномерным волновым распределением. В приповерхностной зоне глубиной до 5 м, представляющей собой уплотненные породы, значения диэлектрической проницаемости составляют менее 8,2-8,5. На глубине от 5 до 120 м (в среднем) они вначале возрастают до 9,5 в пике на глубине 10 м, а затем уменьшаются вновь до 8,1-8,3 и ниже. На этом интервале глубин породы нарушены в большей степени. Ниже глубины 10-20 м (на разных участках) массив пород практически не нарушен, и здесь значения диэлектрической проницаемости практически повсеместно равны 8,2 .

Статистический анализ данных георадиолокационных измерений диэлектрической проницаемости $\varepsilon$ и регистрации числа трещин на 1 пог. м (интенсивности трещиноватости $K_{\text {тр }}$ ) по буровым скважинам участков уступов позволил выявить, что повышенные значения диэлектрической проницаемости на радарограммах коррелируются с большим количеством трещин на 1 пог. м в массиве пород участков.

На рис. 3.7, 3.8 видна четкая корреляция как в характерах изменения графиков, так и в количественных значениях.

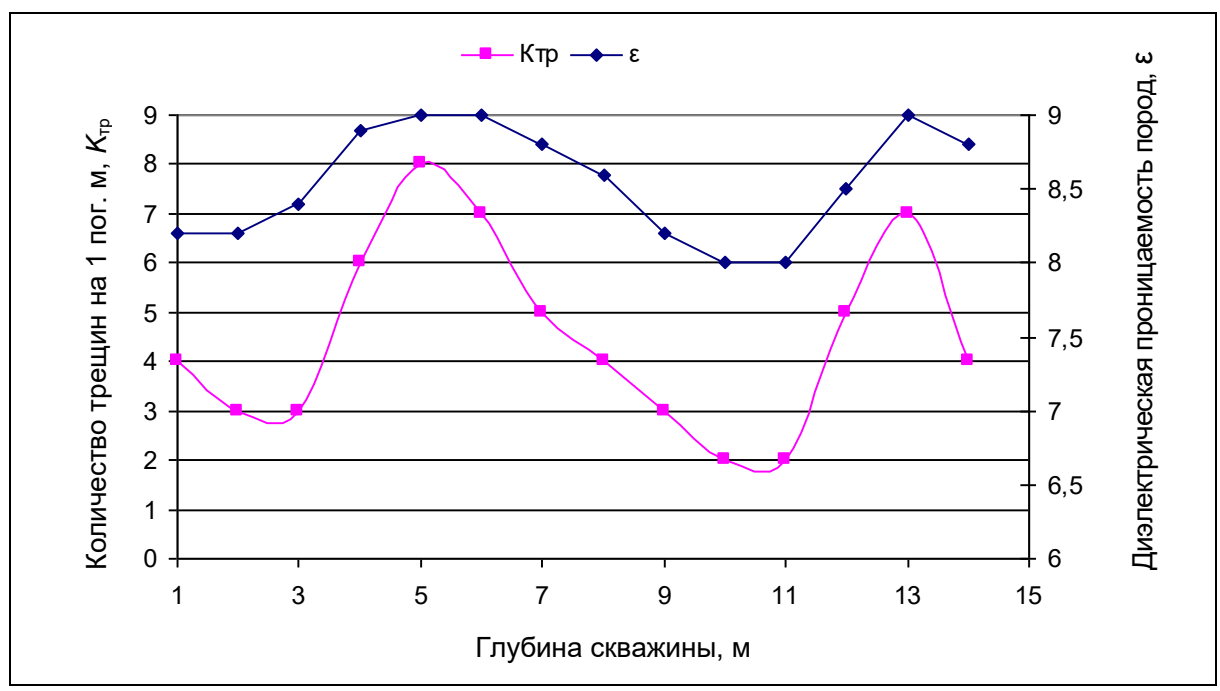

Рис. 3.7. Графики изменения интенсивности трещиноватости $\left(K_{\text {тр }}\right)$ и диэлектрической проницаемости $\varepsilon$ пород по глубине

Таким образом, выявлена взаимосвязь структурной нарушенности массива и диэлектрической проницаемости пород, заверенная телеметрическим обследованием 11 буровзрывных скважин. Установлено, что повышение трещиноватости пород обусловливает повышенные регистрируемые значения их диэлектрической проницаемости.

Анализ значений диэлектрической проницаемости и скорости электромагнитной волны на участках взрывных работ позволил определить зоны нарушенности массива. В результате была выполнена дифференциация геологоструктурного строения оконтуренных массивов пород, по ее итогам в параметры БВР были внесены корректировки для оптимизации качества дробления горной массы. 


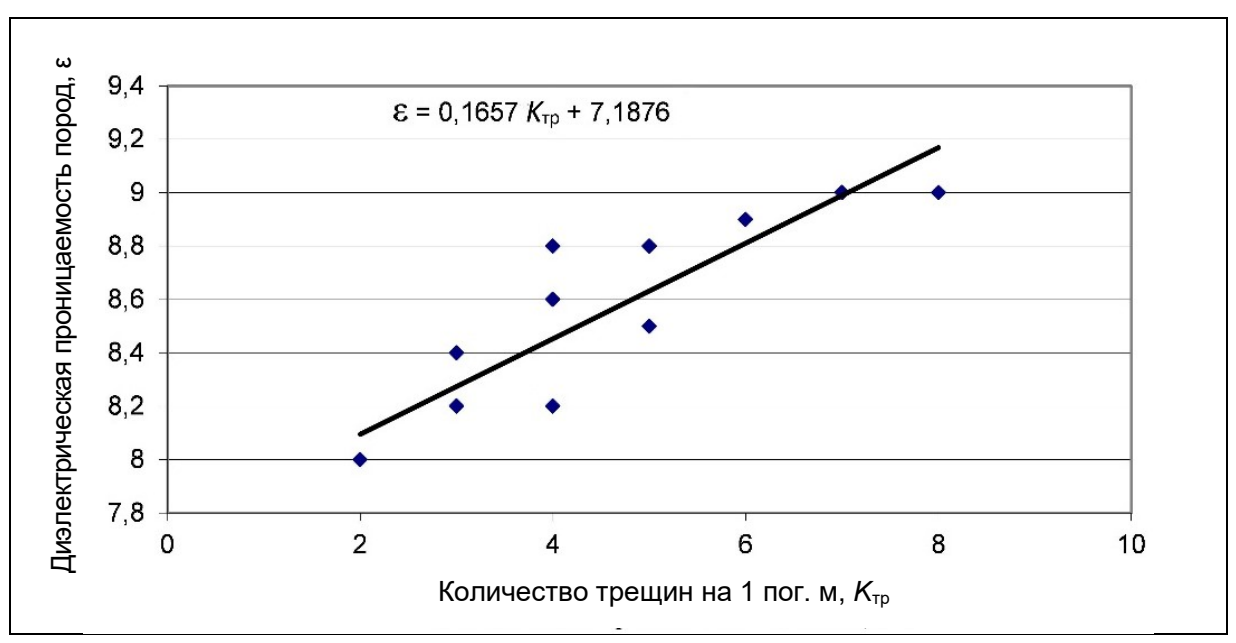

Рис. 3.8. График изменения интенсивности трещиноватости $K_{\text {тр }}$ и диэлектрической проницаемости $\varepsilon$ по шести буровым скважинам

\section{2. Влияние массового взрыва на изменчивость электрофизических свойств скальных пород}

Основным способом подготовки горной массы на карьерах перед ее выемкой является взрывное разрушение горных пород. От качества взрывной подготовки горной массы зависит эффективность последующих производственных процессов, связанных с ее погрузкой и транспортированием. По этой причине оценка результатов скважинной отбойки на участках рабочих уступов с целью определения параметров массового взрыва и их оптимизации является актуальной задачей.

Комплексное применение геодезических и геофизических методов исследования может дать хороший эффект при изучении массивов горных пород с различными целями, включая оценку результатов массовых взрывов, поэтому было проведено комплексное исследование участков рабочих уступов для серии массовых взрывов путем лазерной съемки и георадарного зондирования. Использование такого геодезического метода исследования, как лазерное сканирование, обеспечивает высокую точность и детальность получаемых данных и позволяет строить трехмерные цифровые модели по данным сканирования [53, 54]. Применение геофизических методов, в частности георадиолокации, позволяет определять как степень нарушенности массива до проведения взрывных работ, так и степень дезинтеграции исследуемой среды после их проведения.

Исследования проводились в развитие работ, описанных в разделе 3.1 , при тесном сотрудничестве со специалистами предприятия. В ходе исследований было выполнено лазерное сканирование, георадиолокационное продольное и поперечное профилирование до и после проведения массового взрыва на участках западного, юго-западного и северного бортов карьера.

С целью получения детальных и количественных данных о поверхности участков уступов до и после взрыва были построены их трехмерные модели [56]. 
Исходными данными для построения моделей служили облака точек, полученные при помощи лазерного сканера RIEGLVZ-4000. Обработка данных лазерного сканирования осуществлялась в приложении GeoTech-3D горно-геологической информационной системы MINEFRAME [55]. Для каждого облака точек была выполнена процедура удаления избыточных точек (при сохранении достаточной степени детализации), что позволило снизить их количество в 100 раз.

Трехмерные модели участков уступов были построены посредством триангуляции оставшегося набора точек. На рис. 3.9 представлена фотография и трехмерная модель участка рабочего уступа (горизонт -35 м, запад) до взрыва, на рис. 3.10 - фотография и трехмерная модель развала горных пород, образовавшегося после взрыва на этом участке [56].

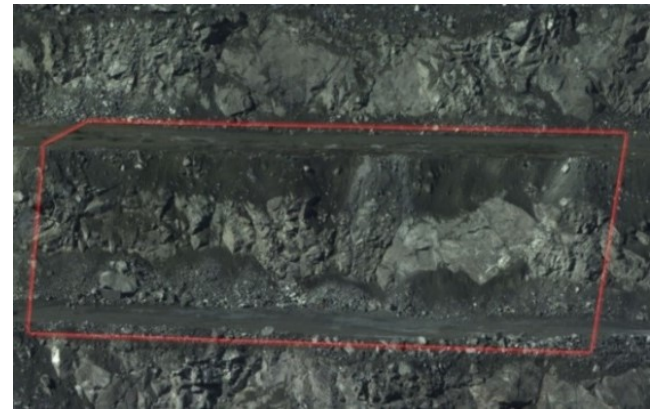

$a$

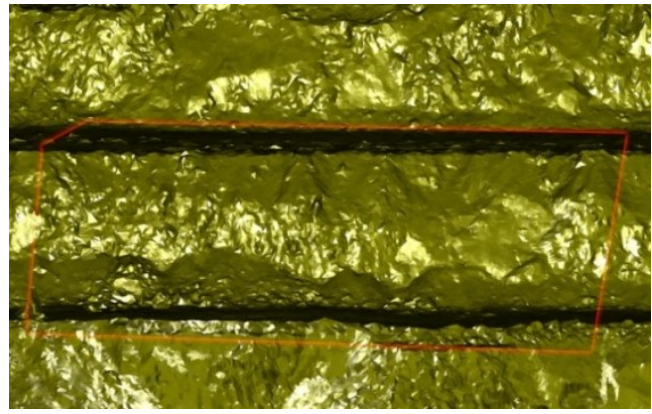

$\sigma$

Рис. 3.9. Фотография участка уступа гор. -35 м, запад:

$a$ - до проведения взрывных работ; $\sigma$ - каркасная модель, построенная по данным лазерного сканирования

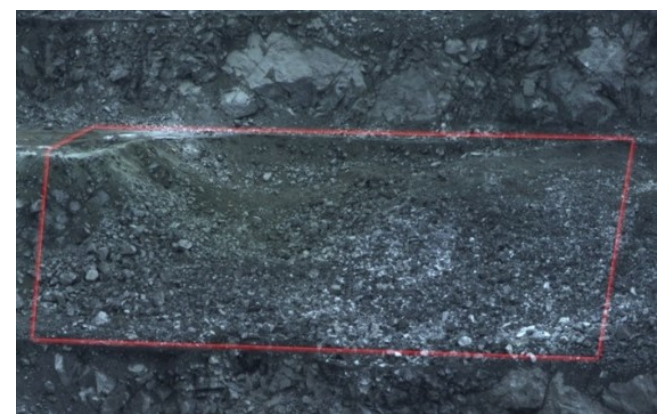

$a$

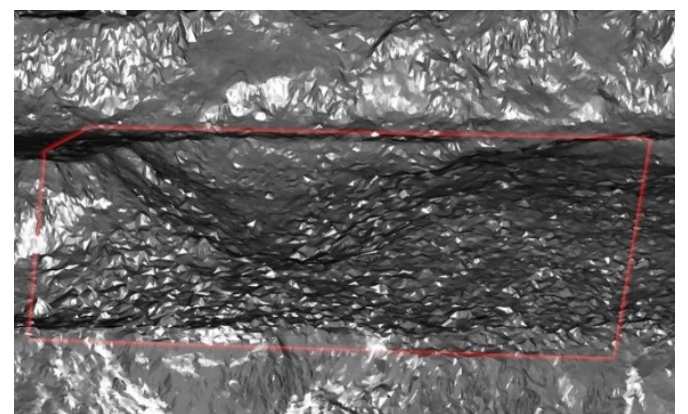

б

Рис. 3.10. Фотография развала после взрыва на участке уступа гор. -35 м, запад (a) и его модель, построенная по данным лазерного сканирования (б)

Совместный анализ каркасных моделей участка (рис. 3.9, б, 3.10, б) до и после массового взрыва позволяет с высокой степенью точности оценить параметры трансформации участка в процессе взрывной дезинтеграции массива горных пород. Кроме того, каркасные модели исследуемых участков одновременно позволили выполнить точную привязку результатов георадиолокационного зондирования к рельефу поверхности. 
Для оценки результатов массового взрыва на участках рабочих уступов выполнено определение линии поверхности отрыва на радарограммах путем выделения и прослеживания осей синфазности отраженных волн от границ раздела сред (развал - нетронутый массив) и их сопоставление с геологическими особенностями разреза по профилю зондирования. Признаками отделения горной массы от массива на радарограммах служили различные характеристики волнового поля (участки с различными типами записи). Результаты георадарного исследования структурного строения уступа обрабатывались с использованием специализированных компьютерных программ (ГЕОРАДАР-ЭКСПЕРТ, RadExplorer) и интерпретировались в радарограммы, представляющие собой скоростные вертикальные разрезы уступа $[43,57,58]$. Вычисление диэлектрической проницаемости также производилось на основе обработки результатов анализа поля обратного рассеяния. Технология позволяет производить построение разрезов как в случае наличия отражающих границ, так и в случае непрерывного изменения электрофизических свойств по профилю наблюдений и по глубине $[59,60]$.

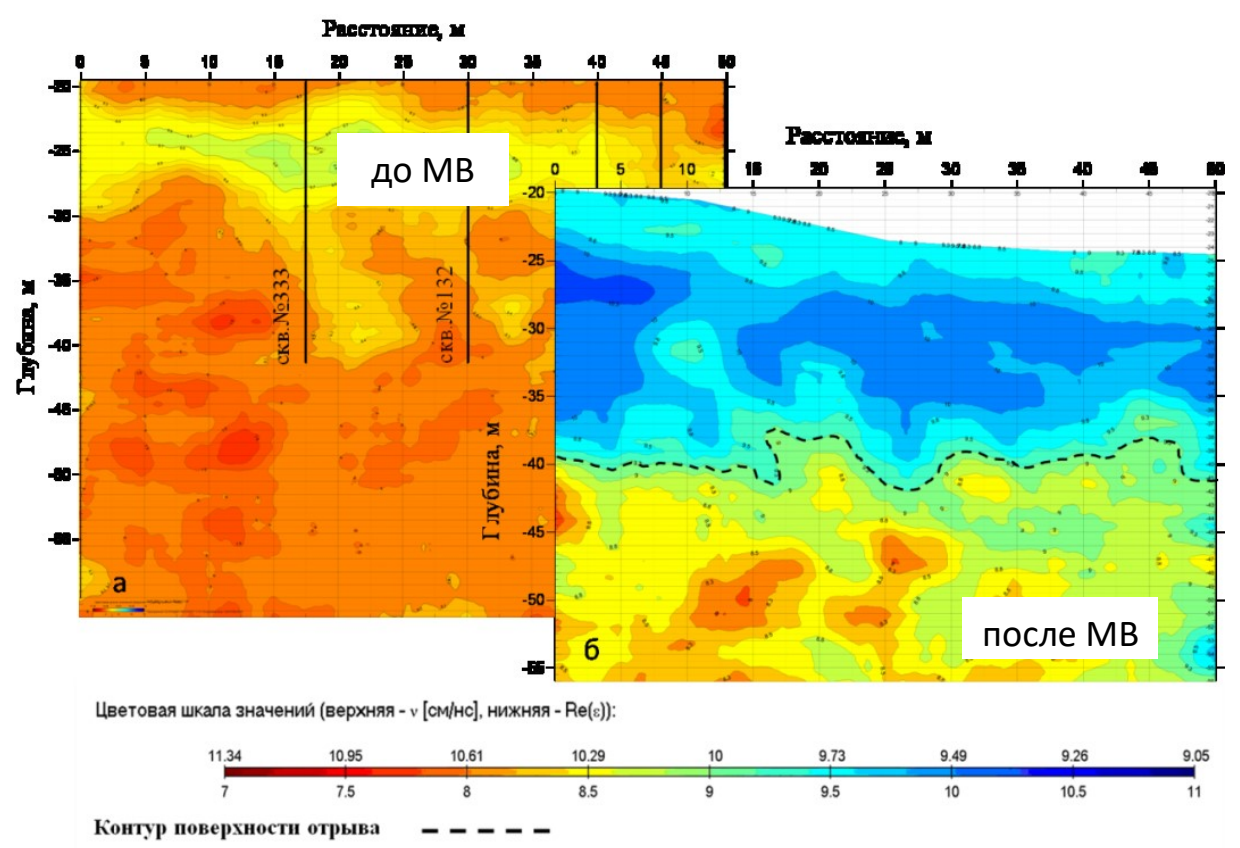

Рис. 3.11. Радарограмма по участку гор. -35 м, запад:

$a$ - до массового взрыва, $\sigma$ - после массового взрыва

Анализ полученных данных (местоположение взрывных скважин, результаты лазерного сканирования до и после массового взрыва, высотные отметки контрольных точек маркшейдерской съемки) по сетке профилей на участке «горизонт -35 м, запад» позволил сделать вывод о том, что значение диэлектрической проницаемости 9,3 является пограничным и может условно считаться линией поверхности отрыва.

На рис. 3.11, б, представлена продольная радарограмма, выполненная по поверхности развала на участке «горизонт -35 м, запад». Следует отметить, что на участке после проведения массового взрыва и до момента георадарного 
зондирования была произведена частичная выемка взрывной горной массы и подсыпка грунта для формирования съезда, что несколько изменило рельеф поверхности. Как видно на рис. 3.11, б, граница линии отрыва по профилю колеблется в интервале глубин 17-20 м (от -39 до -42 м по абсолютной отметке) при глубине взрывных скважин 17,5 м.

На рис. 3.12 представлено изменение контура отрыва по длине площадки по трем продольным профилям 188, 189, 190 участка «горизонт -35 м, запад». Данный участок находился на съезде. Большой разброс изменения контура поверхности отрыва в районе 35-40 м вызван этапным взрыванием всего блока, где середина обследуемого участка являлась границей взрыва двух этапов. Зеленым цветом (пунктирная линия) отмечена усредненная линия границы концов взрывных скважин на обследуемом участке. Методом интерполяции на основе продольных и поперечных радарограмм построена модель поверхности границы разрушения массива горных пород для данного участка (рис. 3.13).

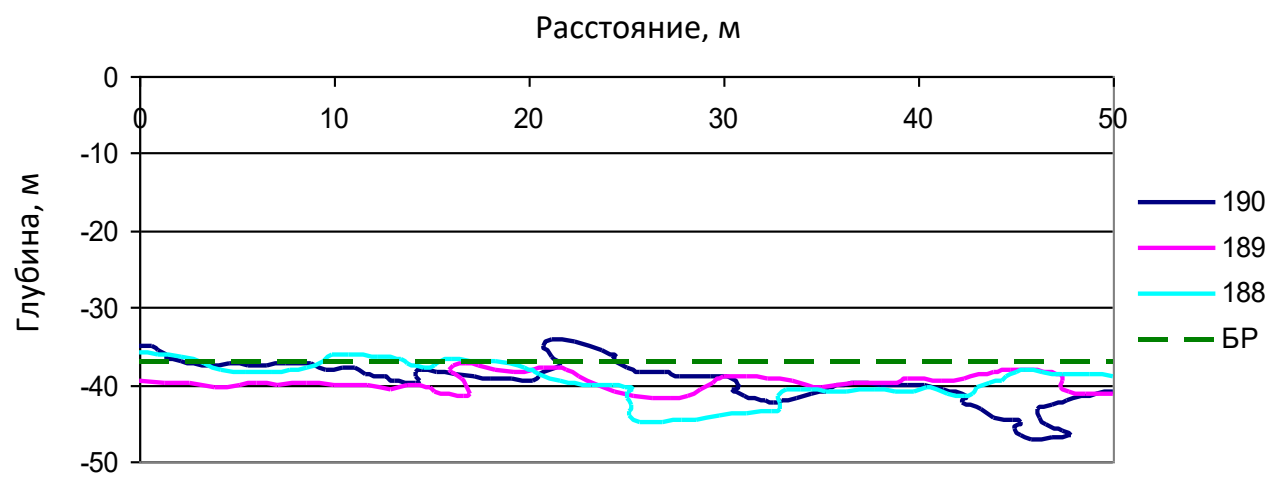

Рис. 3.12. График линий, фиксирующих границу разрушения массива горных пород по профилям георадарного зондирования участка гор. -35 м, запад (значение диэлектрической проницаемости $\varepsilon=9,3$ )

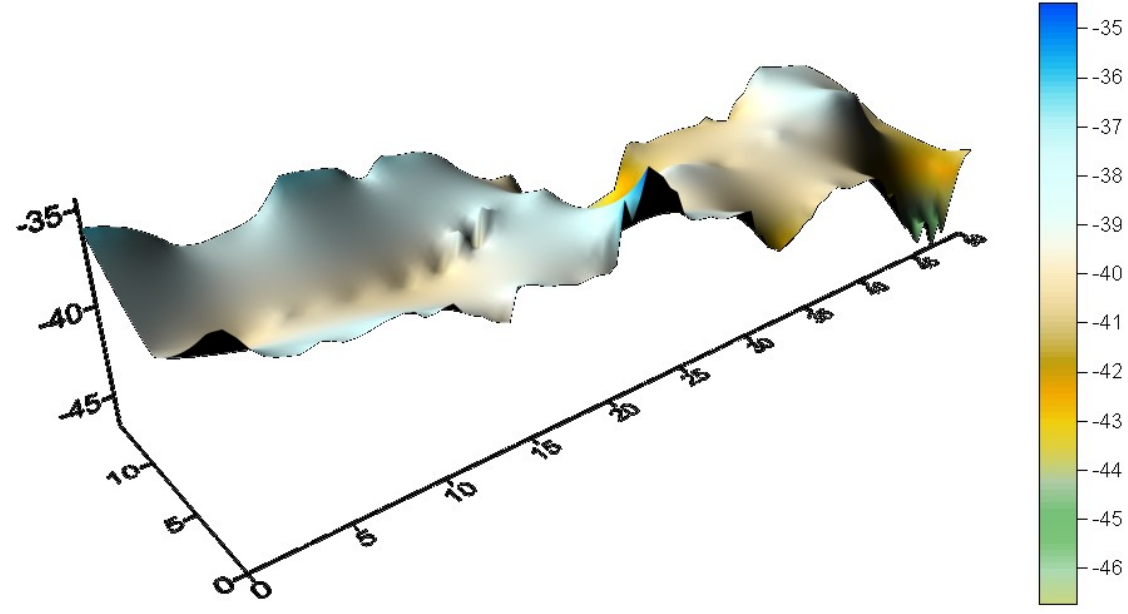

Рис. 3.13. Поверхность границы разрушения массива горных пород участка гор. -35 м, запад 
Комплексный анализ итогов лазерного сканирования и георадиолокационного зондирования позволил установить местоположение границы раздела «отбитая горная масса - массив горных пород», которую можно интерпретировать как границу разрушения. Для получения абсолютных высотных отметок границы разрушения использовались цифровые модели поверхности участков по профилю георадиолокационного зондирования. Ниже приведены результаты анализа по участку рабочего уступа «горизонт -35 м, запад».

Совмещение результатов лазерного сканирования и георадиолокационного зондирования участка уступа до взрыва дало возможность оценить местоположение границы разрушения от взрыва вышележащего блока (рис. 3.14). Как видно из рисунка, глубина границы разрушения от взрыва вышележащего блока варьируется от 0 до 4,1 м относительно поверхности уступа.

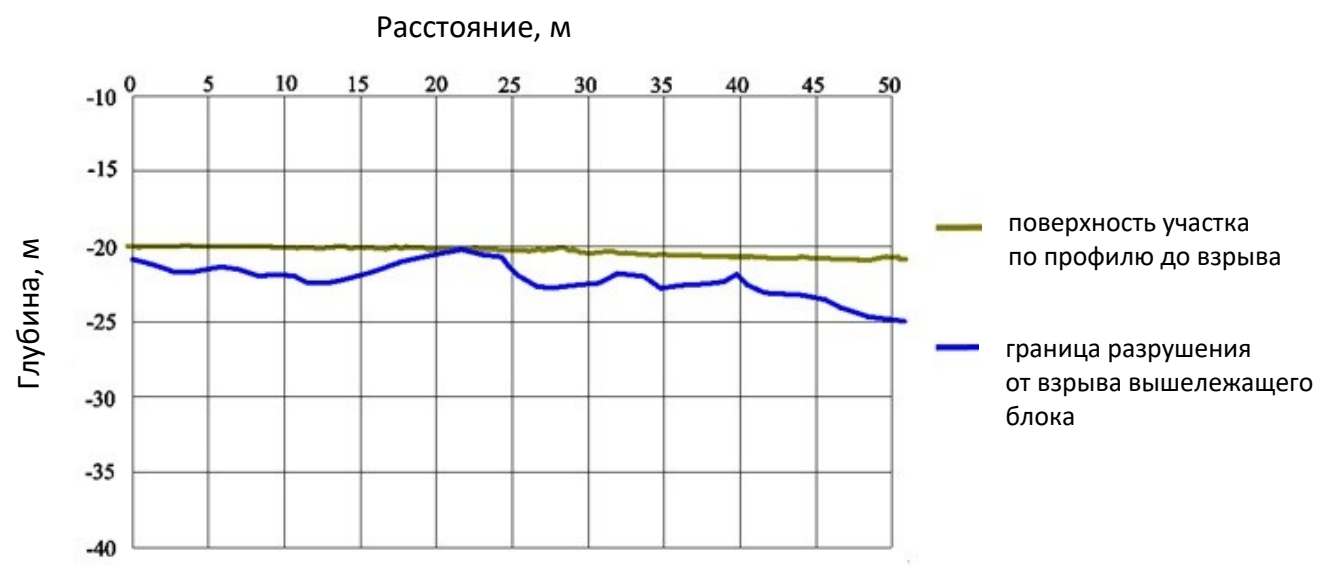

Рис. 3.14. Разрез уступа по профилю георадарного зондирования исследуемого участка уступа до MB с нанесенной границей разрушения от взрыва вышележащего блока

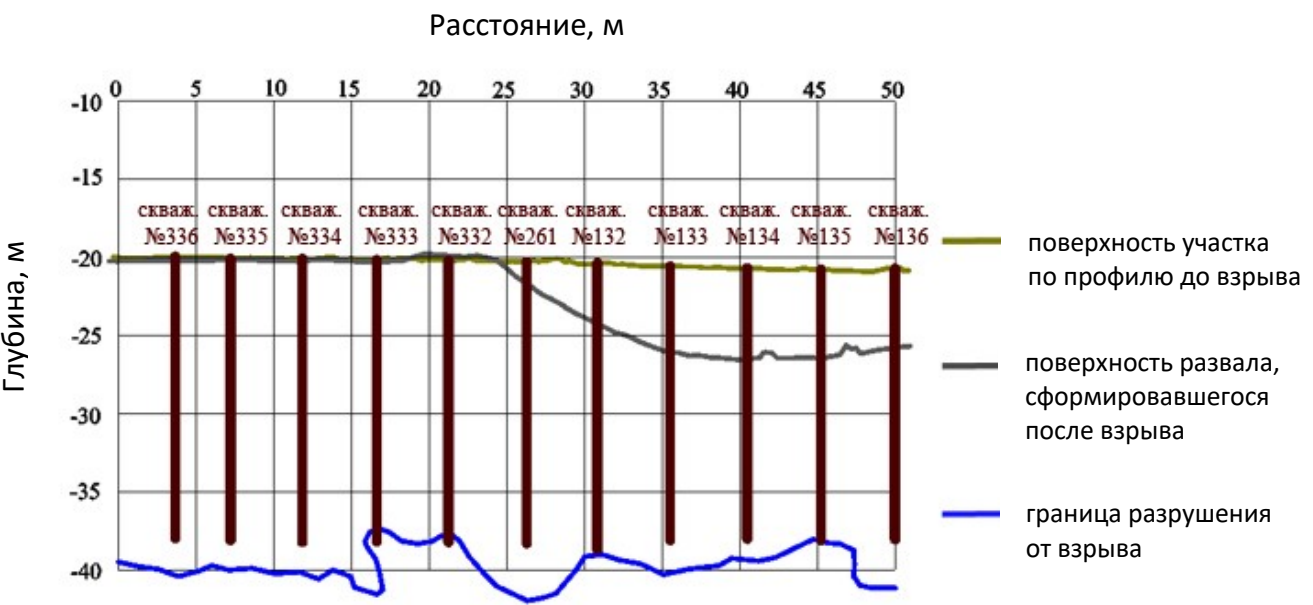

Рис. 3.15. Разрез уступа по профилю георадарного зондирования с проекциями близлежащих скважин до и после MB с нанесенной границей разрушения 
Совмещение итогов лазерного сканирования и георадиолокационного зондирования участка до и после массового взрыва на профиле разреза с вынесением на него местоположения взрывных скважин (рис. 3.15) позволяет с большой уверенностью говорить, что фиксируемая на радарограммах граница раздела двух сред является границей перехода от дезинтегрированного массива горных пород к массиву в ненарушенном состоянии. Подтверждением этого является и расстояние от концов скважин до границы разрушения, которое изменяется от 0,06 до 3,6 м. Такой разброс вполне объясняется тем, что скважины располагаются на разном расстоянии от плоскости разреза по профилю зондирования.

Таким образом, подтверждена установленная ранее взаимосвязь, где нарушенный и ненарушенный взрывом массив горных пород отличается диэлектрической проницаемостью, что может служить диагностическим признаком степени нарушенности исследуемого участка массива. Георадарное зондирование приповерхностного массива на глубине первых десятков метров позволяет, задаваясь выявленным диагностическим признаком, получить линию границы разрушения по профилю зондирования. Совместная интерпретация данных лазерного сканирования поверхности уступа и георадарного зондирования подповерхностного массива позволяет получить достоверную информацию о зонах дезинтеграции массива горных пород и их местоположении в пространстве.

\section{3. Геофизические признаки нарушенности скальных пород}

В данном разделе представлен пример исследования, которое также проводилось на рабочих участках уступов карьера «Железный» $\mathrm{AO}$ «Ковдорский ГОК», при тесном сотрудничестве со специалистами предприятия, с использованием георадиолокационного комплекса Ramac/GPRX3M, оснащенного экранированными антеннами. Полученные данные обрабатывались с помощью специализированных для вида исследований компьютерных программ RadExplorer и ГЕОРАДАРЭКСПЕРТ, интерпретировались раздельно, а затем выполнялся комплексный анализ полученных данных в пространственно-глубинной взаимосвязи.

На рис. 3.16 приведен пример интерпретации георадиолокационных данных, полученных георадаром Ramac/GPR X3M с антенным блоком 100 МГц, с применением стандартной обработки, в результате которой детальный анализ амплитудно-частотных характеристик электромагнитных трасс позволил выявить структурные неоднородности, а также локализовать уровень грунтовых вод (УГВ). По результатам георадарного зондирования выявлена структурная нарушенность в массиве горных пород (мощность около 2 м) на глубине 4-8 м, которая представлена в виде всплеска максимальных амплитуд георадиолокационного сигнала и прослеживается на геологическом разрезе (зона ослаблений). Уровень грунтовых вод фиксируется на глубине 10-12 м и вызывает сильные низкочастотные помехи на всю оставшуюся глубину радарограммы.

Обработка георадиолокационных данных в общепринятом виде включает в себя удаление постоянной компоненты сигнала, прямой волны, коррекцию амплитуд вследствие расхождения и затухания сигнала, применение специализированных процедур обработки (деконволюция, преобразование Фурье и преобразование Гильберта), что в ряде случаев значительно увеличивает 
точность определения местоположения нарушенных зон. Тем не менее в ряде случаев выявленные структурные неоднородности не совпадают, а иногда даже идут вразрез с геологическими данными. Качество интерпретации данных при таком подходе значительно зависит от опыта и уровня интерпретатора.

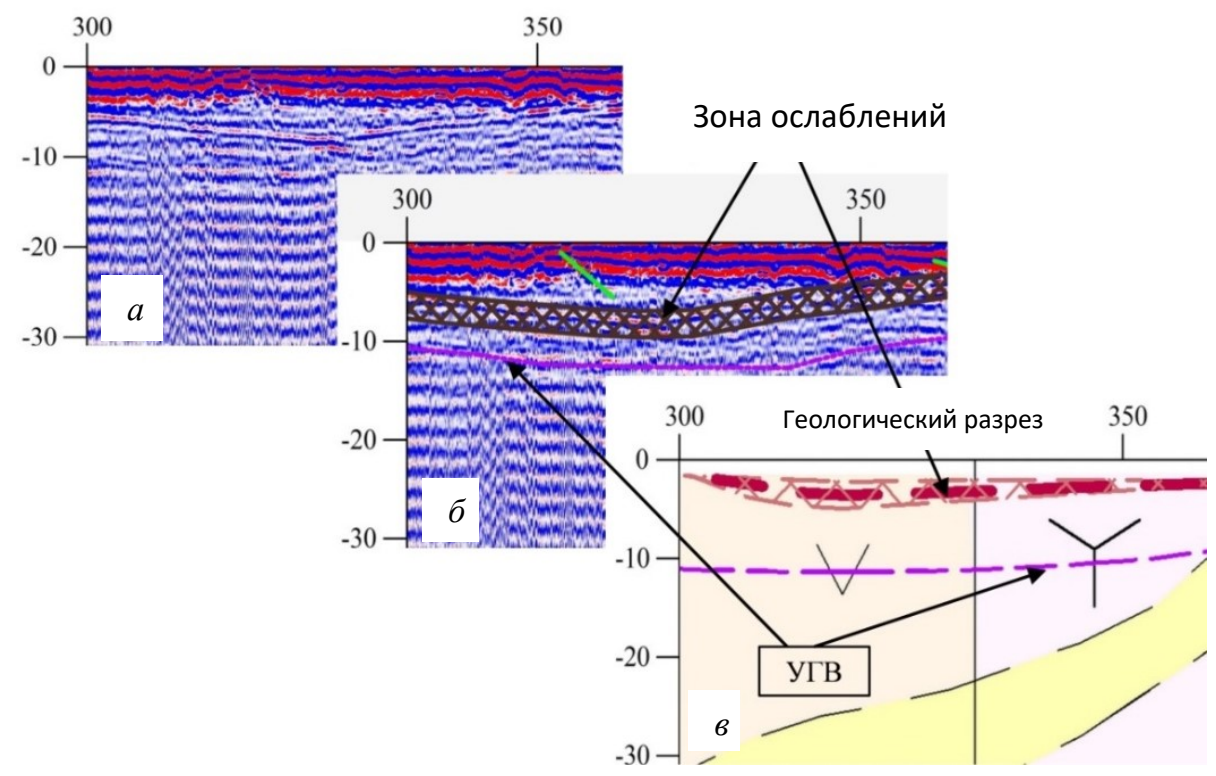

Рис. 3.16. Пример интерпретации данных георадиолокации:

$a, \sigma$ - обработанная и интерпретированная радарограммы; 6 - геологический разрез

Для устранения данного «эффекта» авторами было проведено отдельное комплексное исследование геолого-структурного строения уступа георадиолокационное обследование поверхности уступа по буровзрывным скважинам в комплексе с телеметрическим обследованием и протоколированием визуально определяемых трещин и зон повышенной трещиноватости [59], описанное в разделе 3.1 .

Применение подхода для обработки георадиолокационных данных (рис. 3.16) авторам дало возможность получить разрез в значениях диэлектрической проницаемости (рис. 3.17), фактически скоростной разрез, так как это основной параметр для определения скорости прохождения электромагнитной волны в геологической среде [61].

Как видно из рис. 3.17, в приповерхностной зоне глубиной до 1,5-2 м значения диэлектрической проницаемости колеблются в районе 10,5 (голубая палитра), это, как правило, нарушенная зона от взрыва предыдущего этапа при постановке уступа на контур. Далее на глубине 2-4 м наблюдается незначительное понижение диэлектрической проницаемости до 9-9,5 (желтая палитра), здесь, согласно выявленным ранее закономерностям [59], породы менее нарушены. Далее на глубине 4-8 м профиля выделяется зона повышенных значений диэлектрической проницаемости 12 , где в интервале профиля $0-15$ и 25-40 м достигает пиковых значений - 12,5 (синяя палитра), здесь породы нарушены сильнее всего. Выявленная зона нарушенности по данным анализа значений диэлектрической проницаемости массива скальных пород совпадает 
с проведенным выше для рис. 3.16 детальным анализом амплитудно-частотных характеристик электромагнитных трасс. На глубине 10-12 м, где, по данным геологического разреза, проходит уровень грунтовых вод, значения диэлектрической проницаемости также высоки и составляют 11,5-12, однако отделить границу воды и нарушенной зоны можно только субъективно или опираясь на геологические данные. Ниже 15 м глубины (красная палитра) показатели диэлектрической проницаемости уменьшаются, доходя до значений $7,5-8$, что соответствует нетронутому монолитному массиву.

В то же время увеличение диэлектрической проницаемости является также признаком роста влагонасыщения, что приводит к падению скорости электромагнитной волны и уменьшению глубины обследования. На сегодняшний день известен целый ряд эмпирических выражений, определяющих эту связь. Например, для осадочных пород эти выражения имеют вид: (3.1) - для диапазона изменения влажности от 3 до 45 \% и (3.2) - для высокой влажности [36-39]:

$$
\begin{gathered}
\varepsilon=3,03+9,3 W_{00}+14 W_{00}^{2}-76,7 W_{06}^{3} ; \\
\varepsilon=\frac{720}{180-W},
\end{gathered}
$$

где $\varepsilon$ - действительная часть комплексной относительной диэлектрической

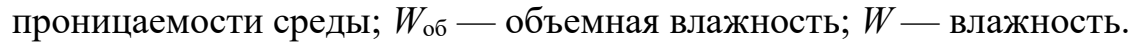

Таким образом, повышенным значениям диэлектрической проницаемости на разрезе может соответствовать как зона структурной нарушенности, так и влагонасыщенный участок, что вновь может привести к неоднозначности трактовка полученных данных, и именно с этим связана сложность интерпретации, разделения границы нарушенной зоны и уровня грунтовых вод (рис. 3.17).

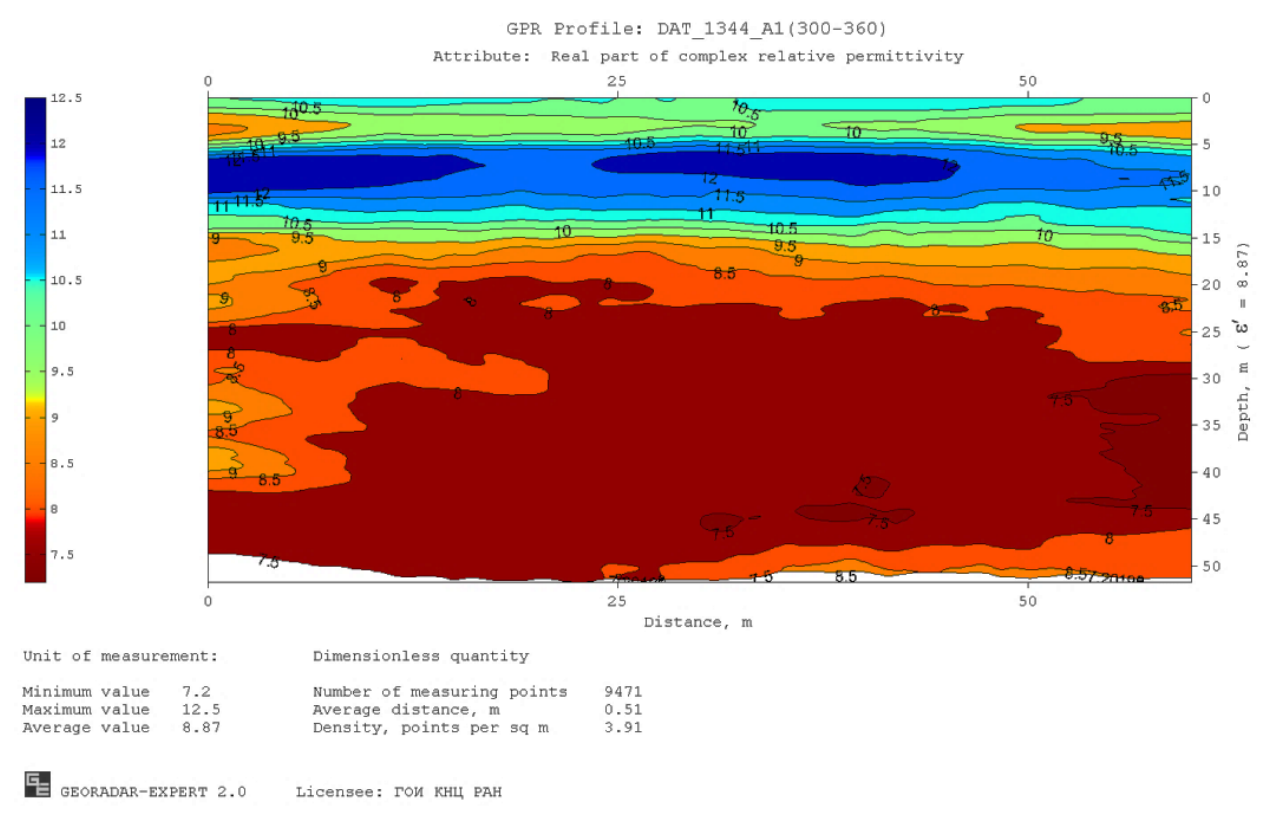

Рис. 3.17. Разрез, построенный на основе данных распределения значений диэлектрической проницаемости 
При рассмотрении возможности атрибутного анализа волнового поля стоит выделить разрез, построенный с использованием атрибута добротности поля обратного рассеяния (рис. 3.18), так называемого $Q$-фактора, который характеризует электромагнитные потери в среде и корреляционно связан с прочностью [19].

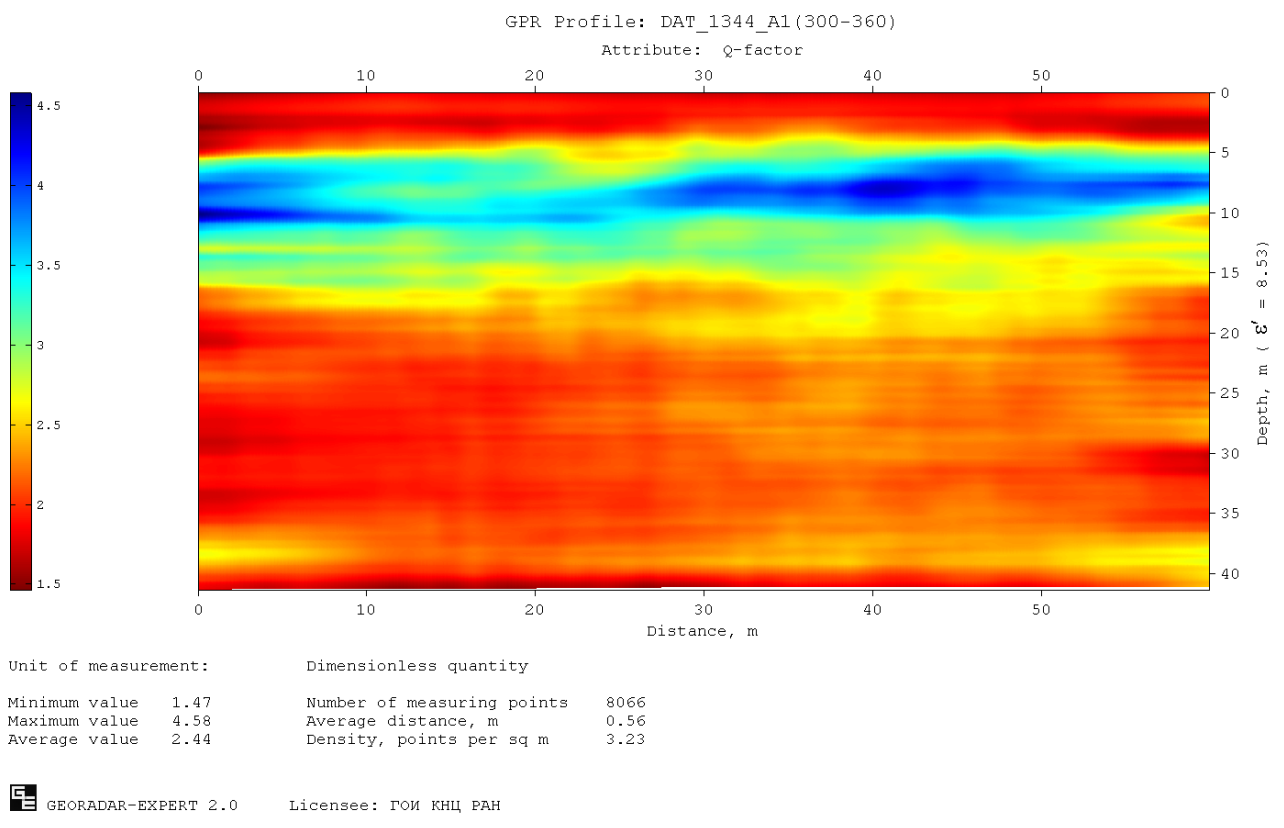

Рис. 3.18. Разрез, построенный по данным распределения атрибута $Q$-фактора

$Q$-фактор в данном случае - это отношение центральной частоты к ширине спектра сигнала по уровню 3 дБ, имеет вид:

$$
Q=\frac{\omega}{\Delta \omega},
$$

где $\omega-$ центральная частота отраженного сигнала георадара, $\Delta \omega-$ ширина спектра отраженного сигнала на уровне $3 д Б$.

Спектр вычисляется для окрестности целевого отражения, например дифрагированного, и чем выше значение добротности, тем острее пик центральной частоты на спектре сигналов.

На основании анализа атрибута $Q$-фактор, исходной радарограммы контрастно выделяется зона высоких значений - 4,5 (синяя палитра), которая отражает потерю сплошности массива и интерпретируется как нарушенная зона, глубина 4-10 м. Значение атрибута $Q$-фактор в остальной части полученного разреза изменяется незначительно и лежит в интервале 1,5 .

Таким образом, опираясь на опыт проведенных работ по оценке нарушенности скальных пород через атрибут $Q$-фактор, можем сказать, что он выступает как показатель сплошности, монолитности скальной породы и чем меньше его значение, тем более монолитна среда и наоборот. 
Применение такого структурного подхода с анализом геофизических признаков георадиолокационных данных для выявления нарушенности скальных пород позволяет существенно повысить точность ее определения и локализации по данным неразрушающего подповерхностного георадиолокационного исследования.

Авторы монографии хотели бы отметить, что данный участок был выбран не случайно, помимо априорной информации в виде геологического разреза, чтобы подтвердить полученные данные, измерения были выполнены незадолго до обрушения этого участка уступа по выявленной зоне ослабления (рис. 3.19) как по результатам бурения, так и георадиолокации. Настоящее исследование позволило наиболее достоверно убедиться в правильности предложенного подхода с анализом геофизических признаков по выявлению зон нарушенности в скальном массиве.

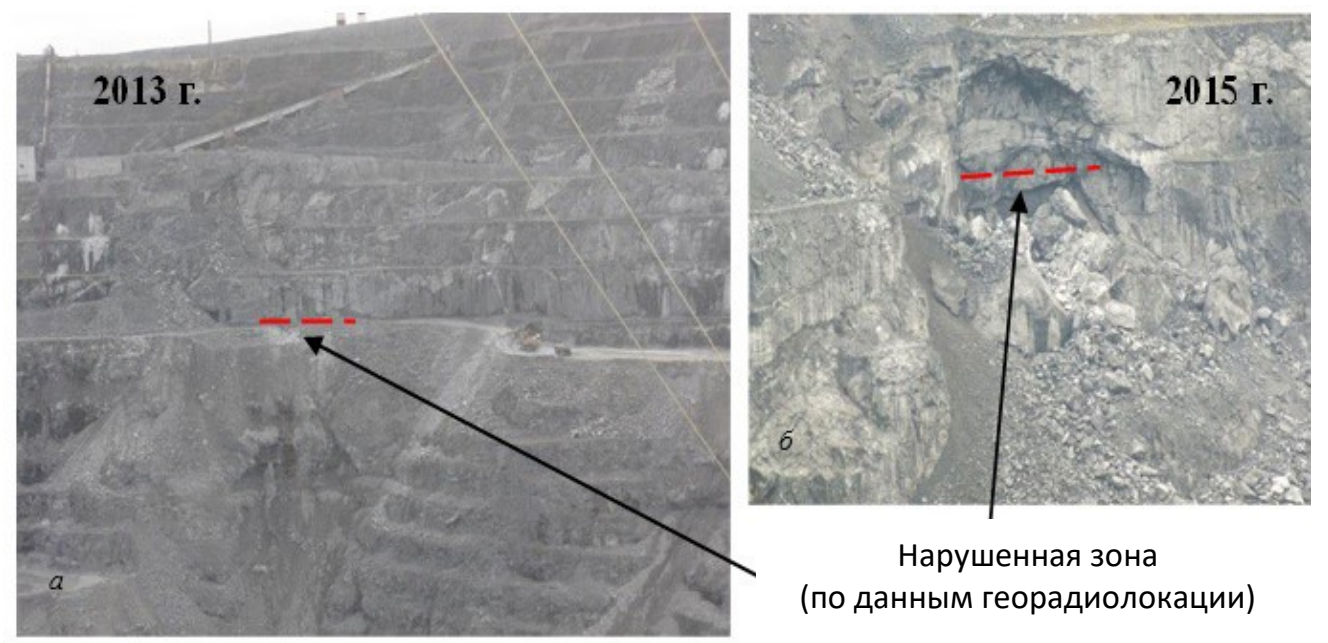

Рис. 3.19. Обрушение по выявленной нарушенной зоне:

$a$ - фрагмент борта до обрушения, $\sigma$ — фрагмент уступа после обрушения

На основе георадиолокационных определений были исследованы геофизические принципы идентификации зон нарушенности скальных пород уступов карьера, заключающиеся в количественной оценке изменения амплитудной характеристики отраженного сигнала, диэлектрической проницаемости разреза и атрибута $Q$-фактор.

Установленная взаимосвязь амплитудно-частотных характеристик отраженного/преломленного сигнала, значений диэлектрической проницаемости разреза и атрибута $Q$-фактор с нарушенностью скальных пород на уступе позволяет оперативно выявлять и оценивать состояние скального массива.

Выполненная оценка состояния законтурного массива пород участков карьера «Железный» Ковдорского ГОКа с использованием предложенного подхода по анализу геофизических признаков может дать основу для принятия дифференцированных, обеспечивающих большую устойчивость параметров уступов и ведения горных работ. 


\section{4. Оценка нарушенности скальных пород георадарным зондированием с использованием водонасыщения для контрастности}

Принимая во внимание то обстоятельство, что обводненность контактных зон и структурных нарушений приводит к изменению физических свойств горных пород вблизи их поверхностей [62], авторы в разделе рассматривают влияние этого фактора на волновую картину радарограмм для выявления в массиве горных пород различного рода структурных неоднородностей (зоны трещиноватости, геологических включений, тектонических нарушений и т. п. Установлено, что на механическую устойчивость скального массива, помимо геолого-структурного строения, технологии разработки месторождений, темпа ведения горных работ, также существенно влияют гидрогеологические условия [63-65]. В зависимости от водонасыщения трещин и пор пород, слагающих отрабатываемое месторождение, устойчивость пород на обнажениях может быть различной. Неоднократно было выявлено, что повышенная обводненность пород отражается в изменении регистрируемых волновых параметров георадиолокации, что свидетельствует об изменении физических свойств горных пород вследствие водонасыщения. Накопленный опыт дает основания утверждать, что георадарные измерения позволяют выполнять оперативный мониторинг степени водонасыщения пород посредством анализа изменения их физических свойств. Это особенно важно в период весеннего снеготаяния или обильных дождей, когда степень обводненности на некоторых участках существенно повышается [66-68]. С другой стороны, выявленная георадарным зондированием изменчивость физических свойств пород в условиях их явной обводненности предоставляет возможность для количественной оценки внутренней несплошности (трещиноватости, пористости, каверности) массива пород. Настоящее исследование направлено на выявление качественных и количественных зависимостей регистрируемых волновых характеристик от степени нарушенности изучаемых пород посредством их контрастного водонасыщения.

Диэлектрическая проницаемость, а следовательно, и скорость распространения электромагнитных волн незначительно зависит от частоты и типа пород, а определяется, главным образом, их влажностью [36-38, 69]. На рис. 3.20 представлено изменение отражения электромагнитной волны при переходе из сухой среды во влажную путем моделирования падения плоской электромагнитной волны на границу двух сред (сухие-влажные породы). Рассматривалось увеличение значений диэлектрической проницаемости второй среды, что соответствует повышению ее влажности. Для сухой породы принято значение диэлектрической проницаемости равное 5 , с поэтапным увеличением значения до 10, 15, 20 на глубине 2 м, что соответствует временному окну 36,2 нс. Моделирование выполнено в программе GPRSim.net (инструмент моделирования плоской волны георадара во временной области) с центральной частотой антенны 500 МГц.

Таким образом, увеличение влажности на радарограммах проявляется в виде более контрастной картины изменения осей синфазности, т. е. увеличением значений амплитуд/отражений на влажных участках, и является своего рода индикатором. 

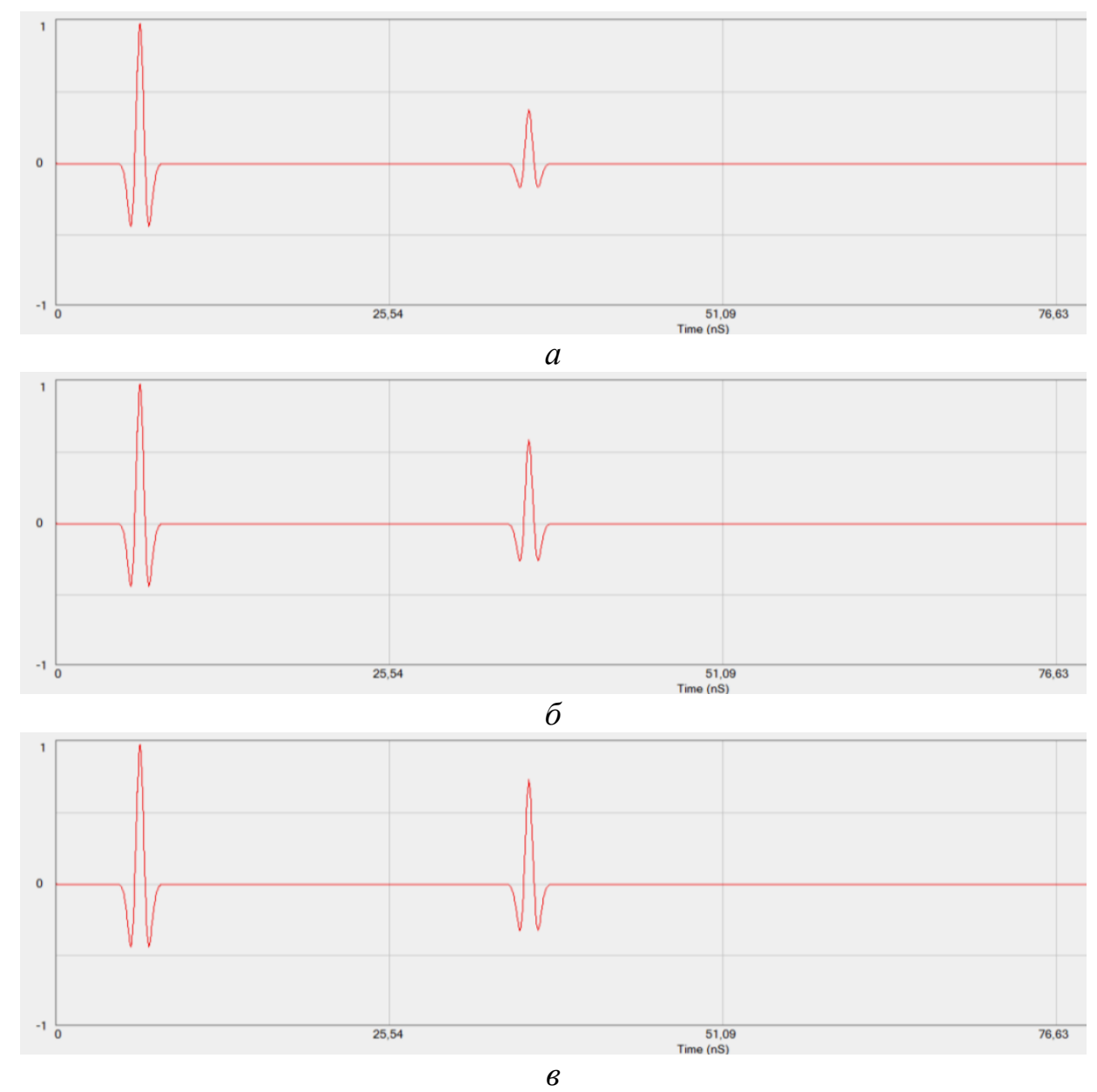

Рис. 3.20. Отражение при переходе сухая-влажная порода: $a-5 / 10$ ед.; $\sigma-5 / 15$ ед.; $в-5 / 20$ ед.

В качестве объекта исследований выбран рабочий уступ горизонта -35 м западного борта карьера «Железный» $\mathrm{AO}$ «Ковдорский ГОК». По геологическому строению исследуемый участок сложен преимущественно ийолитами.

В целях определения строения и выявления структурной нарушенности участка уступа выполнено его комплексное изучение: визуальный осмотр; телеметрическое обследование нескольких буровых скважин (глубиной 18 м, диаметром 0,165 м), находящихся на расстоянии 5 м друг от друга; георадарное продольное зондирование вдоль скважин.

Данные телеметрического обследования скважин и георадарного зондирования были подвергнуты комплексному анализу в пространственноглубинной их увязке. На рис. 3.21 представлены взаимоувязанные по глубине данные визуального обследования и стоп-кадры телеметрии по скважине с условным номером № 1 (a), распределения количества трещин в скважине на 1 пог. м (количественная характеристика интенсивности трещиноватости пород) (б) и фрагмент радарограммы георадарного зондирования в изолиниях диэлектрической проницаемости пород у скважины (в). 


\section{Стоп-кадры \\ телеметрии \\ $2 M$}

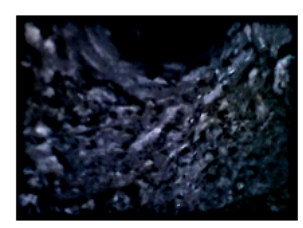

$8 \mathrm{M}$

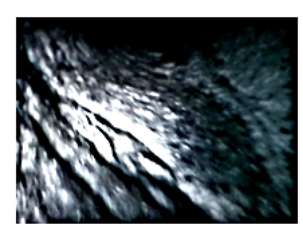

$14 \mathrm{~m}$

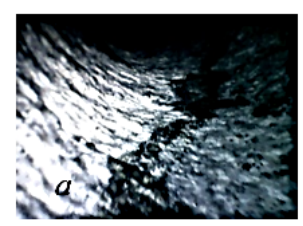

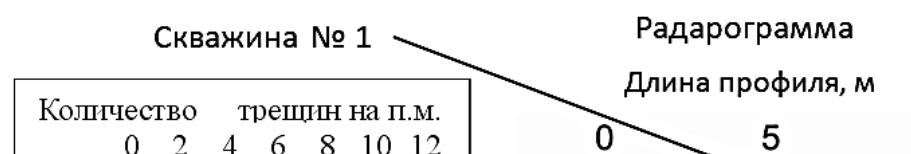
$\begin{array}{lllllll}0 & 2 & 4 & 6 & 8 & 10 & 12\end{array}$
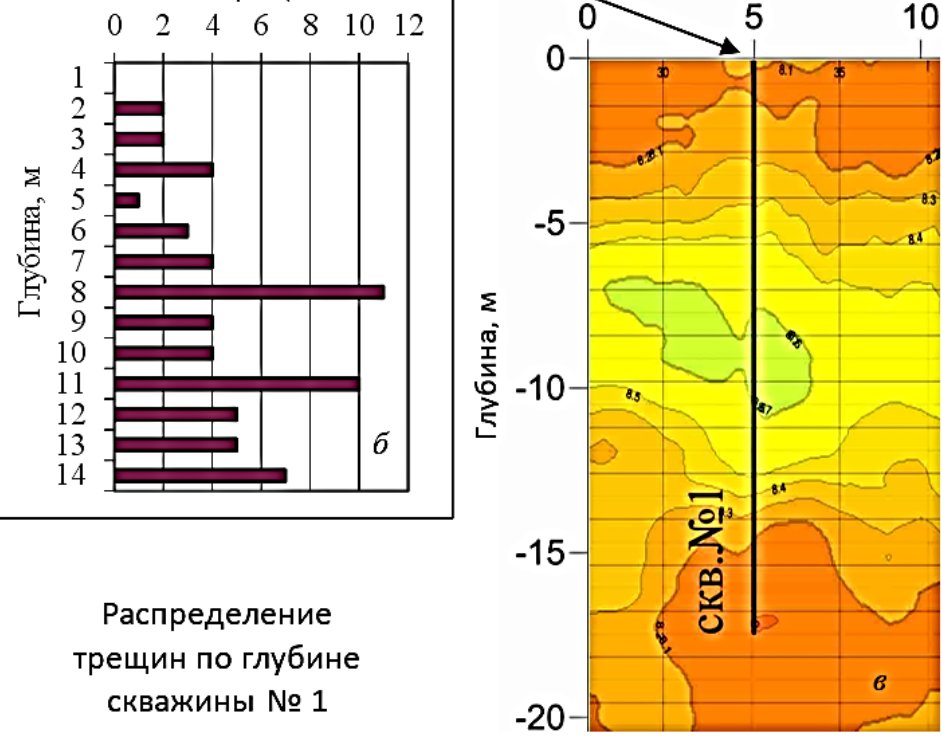

Распределение трещин по глубине скважины № 1

Цветовая шкала значений (верхняя - $v$ [ом/нс], нижняя - Re(s)):

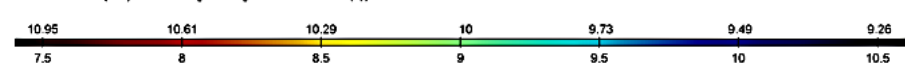

Рис. 3.21. Данные комплексных исследований пород участка уступа у скважины № 1 в пространственно-глубинной их увязке

Анализ гистограммы (рис. 3.21, б) показал, что количество трещин по глубине скважины изменяется от 2-4 трещин на 1 м в приповерхностной зоне (2-7 м) и до 4-11 на интервале 8-11 м. Визуально на радарограмме георадарного зондирования (рис. 3.21, в) для глубин 8-11 м выделяется зона зеленого цвета, в пределах которой значения диэлектрической проницаемости пород равны и выше 8,6 .

Таким образом, можно предположить, что определяемые георадарным зондированием значения диэлектрической проницаемости пород от 8,6 и выше будут соответствовать породам повышенной трещиноватости. Вместе с тем полученные значения диэлектрической проницаемости пород по скважине, несмотря на относительно большое количество трещин на глубине 8-11 м, изменились незначительно: от 8,3 - в приповерхностной зоне до 8,6 на глубине 8-11 м (принимаемая зона более нарушенных пород).

Поэтому в целях получения более контрастных результирующих данных георадарного зондирования был выполнен налив воды в скважину № 1 и проведены режимные георадарные профилирования участка уступа по одному и тому же маршруту. Постепенное понижение уровня воды в скважине фиксировалось замерами во времени, совпадающими со временем режимного георадарного профилирования. 
Анализ динамики уровня воды в скважине № 1 (рис. 3.22) позволил выявить два временных участка фильтрации:

- первый, весьма кратковременный участок графика $0 \leq t \leq 15$ мин, на котором происходит быстрое понижение уровня воды (вследствие ее фильтрации в породы нарушенной приповерхностной части околоскважинного пространства), аппроксимировать который можно следующим выражением:

$$
h=-0,13 t,
$$

где величина достоверности аппроксимации $R^{2}=1$,

- второй, более плавный, в интервале $15 \leq t \leq 60$ мин, по-видимому, вследствие установившегося режима фильтрации воды в породы, который можно аппроксимировать $R^{2}=0,99$ следующим, практически линейным выражением:

$$
h=-0,02 t-1,8,
$$

где $h$ - уровень воды в скважине от поверхности, $t$ - время после выполнения экспресс-налива.

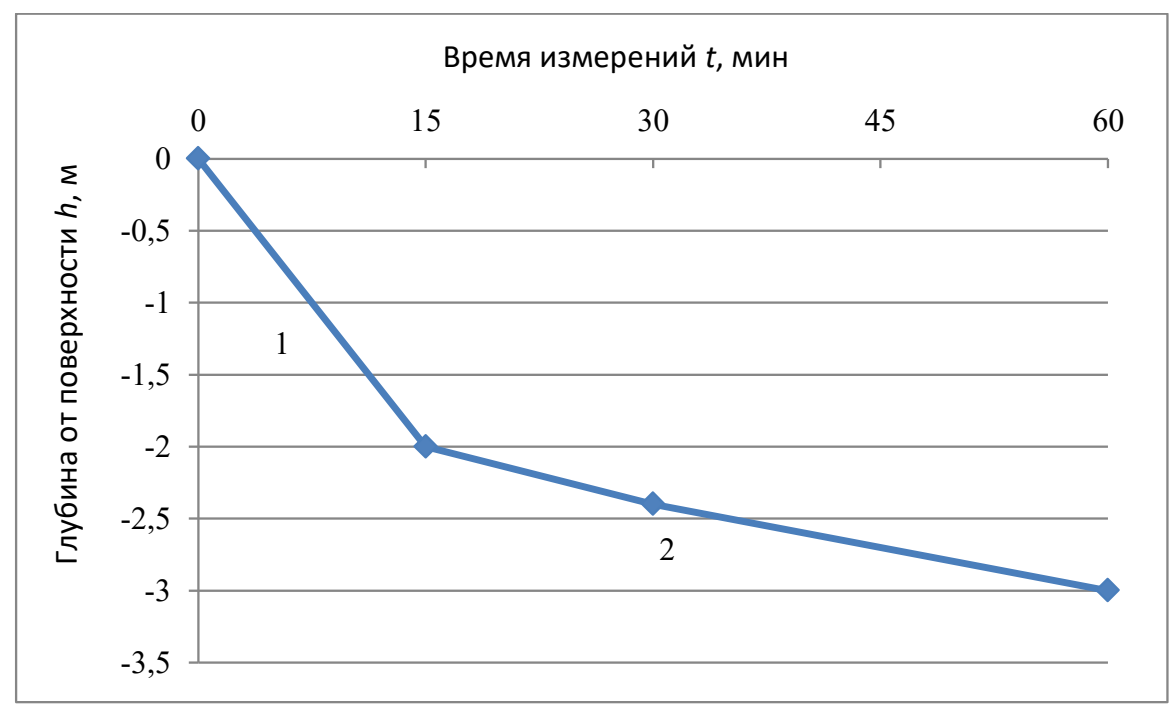

Рис. 3.22. Динамика уровня воды в скважине № 1 после экспресс-налива

Режимные георадарные зондирования участка пород в окрестности скважины № 1 были выполнены до налива и через 15, 30 и 60 мин после налива воды в скважину. Полученные радарограммы обработаны в программе ГЕОРАДАР-ЭКСПЕРТ, рассчитаны значения диэлектрической проницаемости пород (рис. 3.23).

Анализ данных георадарного зондирования, представленных на рис. 3.23 показал, что после проведения налива водонасыщенность пород в окрестности скважины повысилась, что привело к регистрации повышенных значений диэлектрической проницаемости. Как видно из рис. 3.23, через 15 мин после налива воды в скважину регистрируемые значения диэлектрической проницаемости начиная с глубины 5 м возросли и далее составляли от 8,6 до 8,9 на всем оставшемся интервале глубины скважины № 1. 

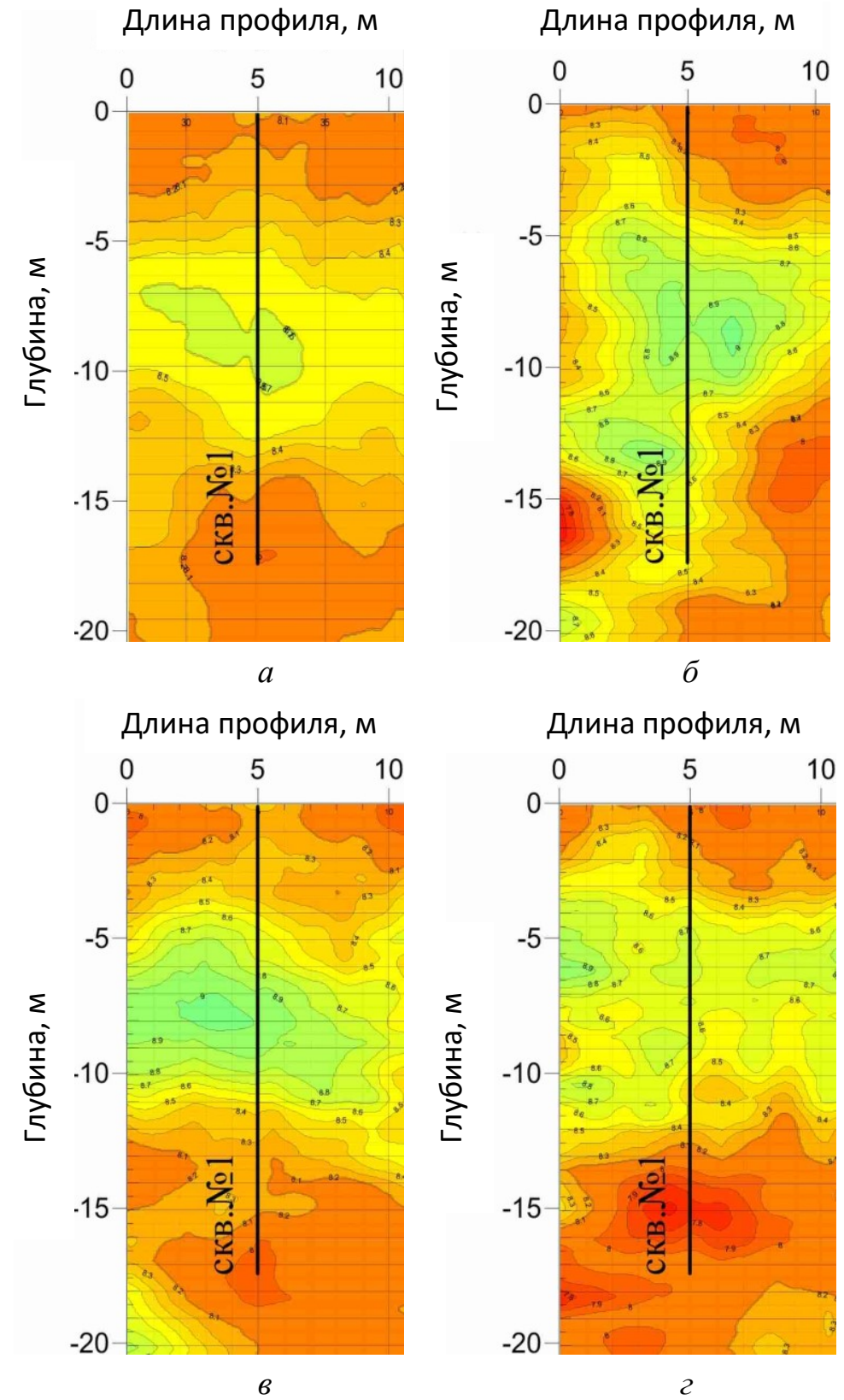

Рис. 3.23. Распределение значений диэлектрической проницаемости в массиве горных пород до и после проведения экспресс-налива: $a-0 ; \sigma-15 ; в-30 ; 2-60$ мин

Спустя 30 мин произошло резкое уменьшение регистрируемых значений диэлектрической проницаемости до 8,2-8,6 на интервале глубин 10-18 м, вместе с тем как в интервале 6-8 м значения диэлектрической проницаемости остались практически без изменений.

Измерениями, выполненными через час (60 мин), было определено, что уровень регистрируемой диэлектрической проницаемости приблизился к значениям 
7,8-8,6, полученным до проведения налива в скважину. Изменения диэлектрической проницаемости до 0,4 в сторону уменьшения на глубине 12-16 м могут свидетельствовать о вымывании водой заполнителя трещин, замещении минеральных частиц пород или уплотнении при некотором смыкании трещин [39, 70]. По результатам телеметрического обследования (рис. 3.21, б), этот участок характеризуется относительно большим количеством трещин - 7-8 на 1 пог. м.

Выполненная георадарным зондированием оценка нарушенности скальных пород уступа карьера с использованием водоналива в скважину для контрастности измерений показала, что сухие/монолитные, слаботрещиноватые породы будут иметь более низкие значения диэлектрической проницаемости, а насыщенные водой, пористые, проницаемые, трещиноватые породы - более высокие значения диэлектрической проницаемости.

Чтобы оценить фильтрационную способность пород в окрестности скважины № 1, имеющей диаметр 0,165 м и глубину 18,3 м, по данным налива вычислен коэффициент фильтрации, среднее значение которого составило $0,011 \mathrm{м} /$ сут.

Коэффициент фильтрации определялся по методике В. М. Шестакова [71]:

$$
k=2,3 \cdot\left(\omega / l_{0}\right) \cdot \lg \left(H_{0} / H\right),
$$

где $\omega-$ площадь горизонтального сечения скважины, $l_{0}$ - расчетный размер водоприемной части скважины, который для скважины с фильтром длиной $l$ и радиусом $r$ равен:

$$
l_{0}=2,73 l / \lg (0,7 l / r) .
$$

Анализ диаграммы прослеживания коэффициента фильтрации (рис. 3.24) позволил сопоставить изменение коэффициента фильтрации со значениями диэлектрической проницаемости во временных интервалах 15, 30 и 60 мин. Значения диэлектрической проницаемости на радарограмме (рис. 3,23, б) в интервале глубин 5-18 м максимально увеличились через 15 мин после налива воды в скважину на 0,6 ед. в интервале 8,6-8,9 ед., в свою очередь, средний коэффициент фильтрации $k$ здесь максимален и составляет 0,024 м/сут. Далее коэффициент фильтрации равномерно уменьшается на протяжении всего цикла измерений. Через 30 мин значения диэлектрической проницаемости на глубине 5-18 м (рис. 3.23, в) уменьшились и лежат в интервале 8,4-8,7 ед., также и среднее значение коэффициента фильтрации $k$ снизилось, составив 0,015 м/сут. Через 60 мин после налива значения диэлектрической проницаемости приблизились к показателям, полученным до проведения налива в скважину, коэффициент фильтрации $k=0,0011$ м/сут. Таким образом, выполненный анализ показал, что, согласно классификации горных пород [72], по степени водопроницаемости породы относятся к IV категории: слабо- или полупроницаемые с коэффициентом фильтрации $k<0,1 \mathrm{~m} /$ сут.

Для определения пустотности (П) рассмотрим массив скальных пород в форме цилиндра диаметром 10 м, глубиной 18,3 м и скважину № 1 в центре, в которую осуществлялся налив. Объем $V$ породы цилиндра с водой в скважине составил 1436,55 м³ , через 15 мин после налива уровень воды уменьшился на 2 м. Таким образом, объем воды, заполнивший трещины и поры вмещающих 
скальных пород, составил $0,043 \mathrm{~m}^{3}$. Отношение объема воды во времени к общему объему исследуемого участка отражает состояние пустотности массива пород в определенный момент времени по глубине. На рис. 3.25, a, представлено изменение пустотности через 15, 30 и 60 мин.

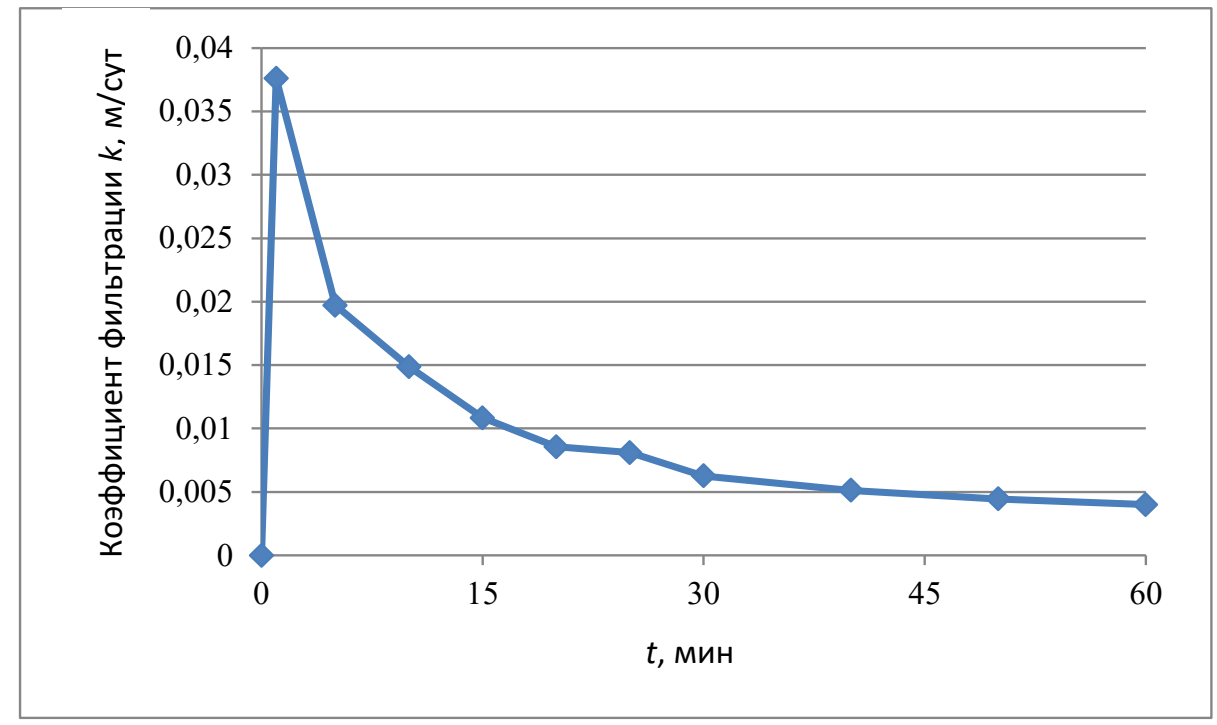

Pис. 3.24. Диаграмма временного прослеживания коэффициента фильтрации

Анализ диаграммы временного прослеживания пустотности в скважине № 1 (рис. $3.25, a$ ) позволил выявить два временных участка:

- первый, весьма кратковременный, участок графика $0 \leq t \leq 15$ мин, на котором происходит значительное увеличение значений пустотности от $1 \cdot 10^{-5}$ до $3 \cdot 10^{-5}$, аппроксимировать $R^{2}=0,88$ который можно следующим выражением

$$
\Pi=2 \cdot 10^{-6} t+9 \cdot 10^{-6} ;
$$

- второй, более плавный, в интервале $15 \leq t \leq 60$ мин, по-видимому, вследствие установившегося режима фильтрации воды в породы (рис. 3.22), который можно аппроксимировать $R^{2}=0,97$ следующим практически линейным, выражением

$$
\Pi=3 \cdot 10^{-7} t+3 \cdot 10^{-5},
$$

где П — пустотность, $t$ - время после выполнения экспресс-налива.

В свою очередь, значения диэлектрической проницаемости после проведения налива в скальную породу показали тенденцию к увеличению на протяжении всего времени наблюдений (рис. 3.25, б) и описываются выражением

$$
\varepsilon=0,0086 t+8 \text {. }
$$

Таким образом, вода, налитая в скважину в скальных породах, перемещаясь по трещинам и порам, позволила определить пустотность и контрастное изменение диэлектрической проницаемости скальных пород под действием водонасыщения. 


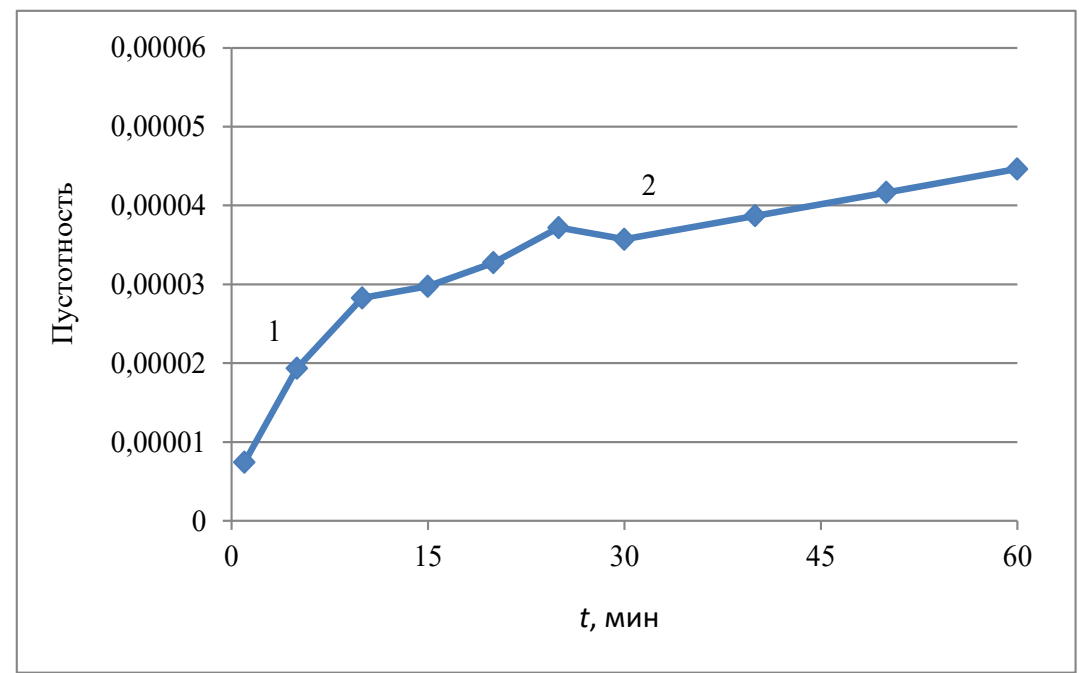

$a$

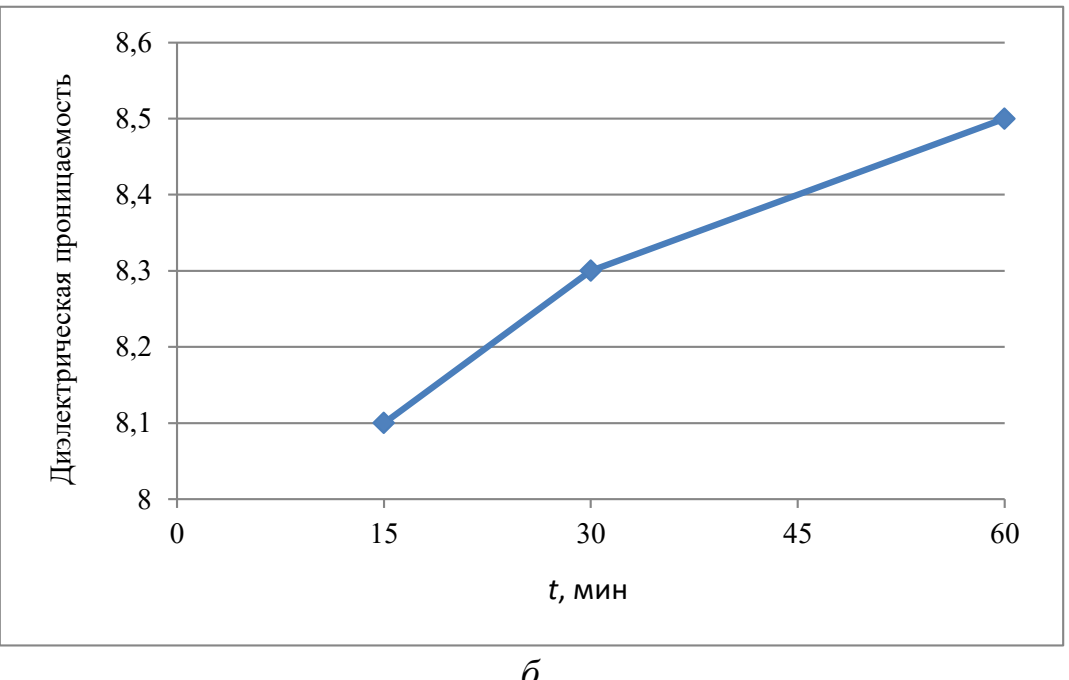

Рис. 3.25. Диаграмма временного прослеживания пустотности (a) и диэлектрической проницаемости в массиве пород (б)

По рассчитанным значениям диэлектрической проницаемости пород (рис. 3.23) построены графики их изменчивости по оси скважины (рис. 3.26).

Как видно из рис. 3.26 , а, после проведения налива скважины № 1 образовалось несколько зон, разделенных пунктирными линиями, которые в определенной степени характеризуют этот участок массива пород. На интервале глубин 0-1,8 м, выделяемых как приповерхностная зона, особых изменений в значениях диэлектрической проницаемости для $t=0$ и после проведения налива $t>0$ не происходит.

На следующем интервале 1,8-5 м идет постепенное увеличение значений диэлектрической проницаемости для всех временных интервалов, что может быть связано с изменением свойств породы по глубине. Интервал 5-6,2 м соответствует максимальным значениям диэлектрической проницаемости до проведения налива в скважину № 1, что соответствует трещиноватому массиву. 
Изменение диэлектрической проницаемости по скважине №1

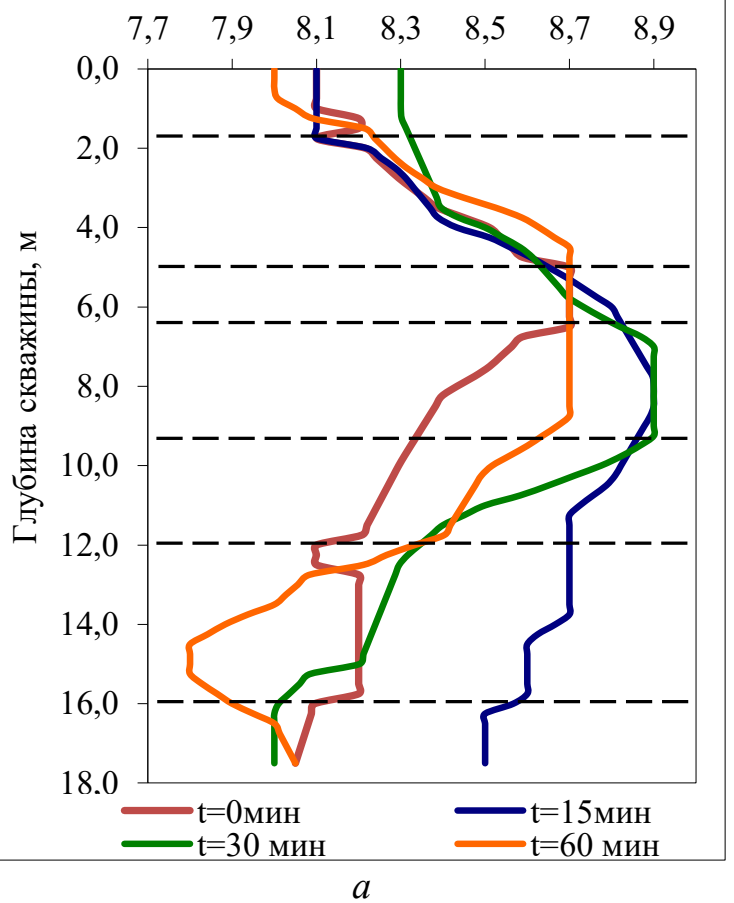

Приращение диэлектрической проницаемости по скважине №1 после налива

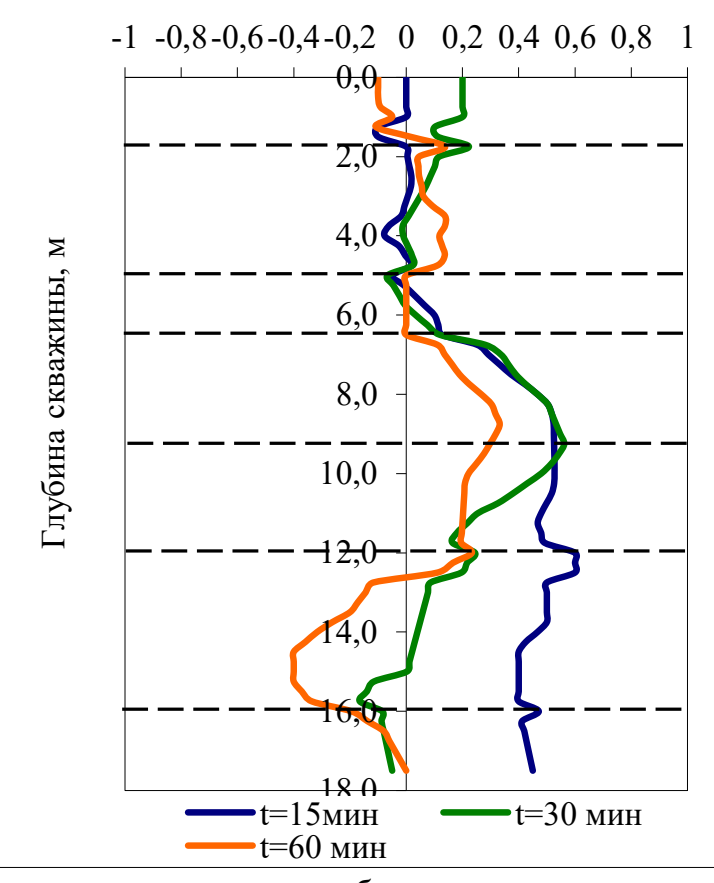

Рис. 3.26. Зависимости значений диэлектрической проницаемости пород у скважины $(a)$ и их приращений (б) 
На глубине 6,2-12 м максимальное изменение показателей диэлектрической проницаемости (до 0,6) произошло после налива воды через 15 мин. По мере понижения уровня воды в скважине и ее распространения в околоскважинном пространстве картина изменения диэлектрической проницаемости меняется. Через 30 мин в интервале глубин 12-16 м зафиксировано небольшое падение значений диэлектрической проницаемости до 0,2, с сохранением высоких значений до 0,6 на глубине 9,5 м. На интервале 16-18 м показатели диэлектрической проницаемости изменились незначительно. В слабопроницаемых породах вода по трещинам и порам, вымыв возможный заполнитель, распространилась практически везде, в интервале глубин 2-12 м повсеместно значения диэлектрической проницаемости увеличились, тем самым позволив более детально определить степень нарушенности пород.

На рис. 3.26, б, представлено изменение (отклонение) зарегистрированной диэлектрической проницаемости после налива воды в скважину, где за исходное состояние массива взято значение диэлектрической проницаемости при $t=0$, т. е. до налива воды в скважину. Изменение значений диэлектрической проницаемости на 0,5 в интервале глубин 8-10 м коррелирует с исходным водонасыщением массива скальных пород по трещинам, что подтверждается данными телеметрического обследования скважины № 1 до проведения налива (рис. 3.21, б), где на 8 и 11 м скважины отмечается большое количество увлажненных трещин на погонный метр (10-11 шт.).

Проведенные исследования позволили выявить влияние воды на результаты георадарного зондирования, а также определить категорию пород по степени водопроницаемости. Установлено, что вода является индикатором, который позволяет более контрастно выявлять зоны нарушенности пород ввиду относительно незначительной разности диэлектрической проницаемости в естественном ненарушенном и нарушенном массиве. Определена взаимосвязь структурной нарушенности пород и их диэлектрической проницаемости под действием водонасыщения пород. Проведенный анализ позволил выявить количественное влияние воды как фактора определения неоднородности. Целенаправленный налив в скважину показал резкое изменение контрастности диэлектрических свойств в массиве пород. Полученные выводы и значения диэлектрической проницаемости позволяют создать основу для определения сезонного воздействия природных факторов на состояние массива скальных пород, а также выявлять тенденции его изменения, имеющие немаловажное значение в арктических климатических условиях.

\section{5. Определенные закономерности взаимосвязи параметров георадарных исследований и напряженного состояния пород}

Отдельным разделом авторы выносят вопрос о возможной взаимосвязи напряженно-деформированного состояния пород уступов карьера и его влиянии на волновую картину радарограмм. Стоит отметить, что на формирование напряженно-деформированного состояния пород уступов карьера влияет большое количество факторов, однако наиболее важными являются исходные геологические условия массива пород, геометрические и горнотехнические параметры уступов и их отработки. Оценка напряженно-деформированного состояния пород уступов осуществляется на основе либо натурных определений 
методом разгрузки $[73,74]$, либо путем численных расчетов методом конечных элементов [75], граничные условия в которых задаются исходя из результатов натурных измерений.

Вместе с тем общеизвестным и принимаемым большинством исследователей является тот факт, что измерения методом разгрузки в горизонтальных скважинах в уступах карьера локализованы и носят точечный характер. В случае двух и более измерительных станций с определенной степенью доверительности возможна квазилинейная аппроксимация значений напряжений в породах межстанционного пространства, но за пределами этого пространства, а также в случае только одной измерительной станции экстраполяция результатов измерений даже на близлежащий массив пород требует обоснования и фактического подтверждения.

Представляется, что точечные измерения методом разгрузки (как первичные методы) должны подкрепляться площадными исследованиями, выполняемыми оперативными геофизическими методами: электромагнитное зондирование, микросейсмопрофилирование и др., которые для данных целей могут рассматриваться как вторичные [42, 76]. Обязательным условием комплексирования указанных методов должна являться маркшейдерская привязка измерительных станций и профилей геофизических определений. Комплексное применение метода разгрузки и геофизических методов позволит дать более объективную и, что немаловажно, дифференцированную картину распределения напряжений в уступах карьера, предоставляющую возможность оперативного решения задач маркшейдерского обеспечения и оптимизации параметров БВР.

Для изучения вопроса возможной взаимосвязи параметров георадиолокации и напряженно-деформированного состояния пород исследованы возможности применения высокочастотного электромагнитного зондирования как вторичного, дополняющего метод разгрузки, метода исследования количественной оценки напряженного состояния пород рабочих уступов карьера. При этом для пространственной оценки напряженно-деформированного состояния пород рассматриваемого участка в качестве промежуточного (переходного) звена интерпретации натурных определений использовалось компьютерное моделирование методом конечных элементов.

Высокочастотное электромагнитное зондирование пород уступов было выполнено с применением георадарных технологий [57] на участке наблюдательных станций (н. с.) разгрузки 15 и 16 на горизонте +40 м восточного борта карьера рудника «Железный» Ковдорского ГОКа. На рис. 3.27 приведены профили георадарных определений в привязке к измерительным станциям и уступам. На основе выполненного высокочастотного электромагнитного зондирования уступов карьера по профилям построены волновые картины радарограммы, отражающие состояние законтурного массива пород на глубину до 20-40 м, обусловленное напряженно-деформированным положением, сплошностью (трещиноватостью) и влагонасыщенностью пород.

В целях пространственного анализа электромагнитных характеристик и состояния законтурного массива пород уступов выполнено компьютерное моделирование напряженно-деформированного состояния методом конечных элементов. Построена трехмерная математическая модель, ее исследование явилось дополнительным промежуточным звеном для выявления тенденций распределения напряжений в массиве пород на основе георадиолокационных 
данных. Отметим, что, применив метод интеграции при задании граничных условий в исследовании модели, авторы достигли удовлетворительной сходимости результатов и в последующем осуществили интерпретацию амплитудно-частотных характеристик, коррелирующих с изменением напряженнодеформированного состояния пород.

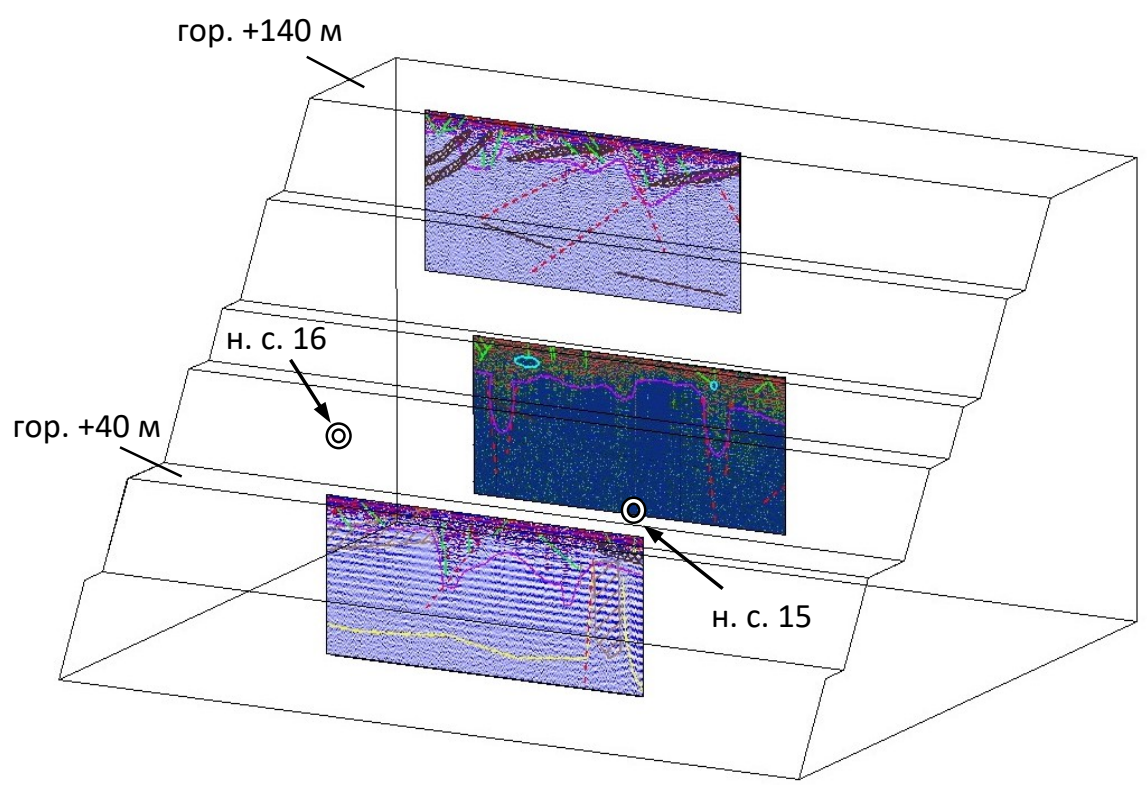

Рис. 3.27. Георадарные исследования в привязке к измерительным станциям методом разгрузки

Расчетная 3D-схема реализовывала разработанную модель и имитировала участок карьера с горизонтальными размерами $400 \times 400$ м, вертикальным -250 м (рис. 3.28). Физико-механические свойства пород задавались соответствующими усредненным данным по наблюдательным станциям 15 и 16: объемный вес $\gamma=3000$ кг $/ \mathrm{cm}^{3}$; модуль Юнга $E=8,5 \mathrm{MПа;} \mathrm{коэффициент} \mathrm{Пуассона} v=0,19$. Граничные условия для моделирования: нижняя граница закреплена жестко $\left(u_{x}=0 ; u_{y}=0\right)$, остальные границы модели не имеют закрепления, т. е. перемещения разрешены во всех направлениях.

Рассматривалась изотропная модель под действием собственного веса пород с учетом бокового отпора и действия тектонических сил $T_{x}=20 \mathrm{MПа;}$ $T_{y}=5$ МПа (см. рис. 3.28). Расчеты выполнены методом конечных элементов в упругой постановке объемной задачи [77-79].

Полученные расчетные данные сопоставлены с данными метода разгрузки по наблюдательным станциям 15 и 16 (табл. 3.1, рис. 3.29, где зеленый, синий и красный графики - максимальная касательная, минимальная и максимальная компоненты квазиглавных напряжений соответственно, пунктиром обозначены расчетные значения напряжений). Анализ табличных и графических данных позволяет сделать вывод об их достаточно удовлетворительной сходимости, что подтверждает адекватность построенной модели и выполненного ее исследования по данным натурных определений. 


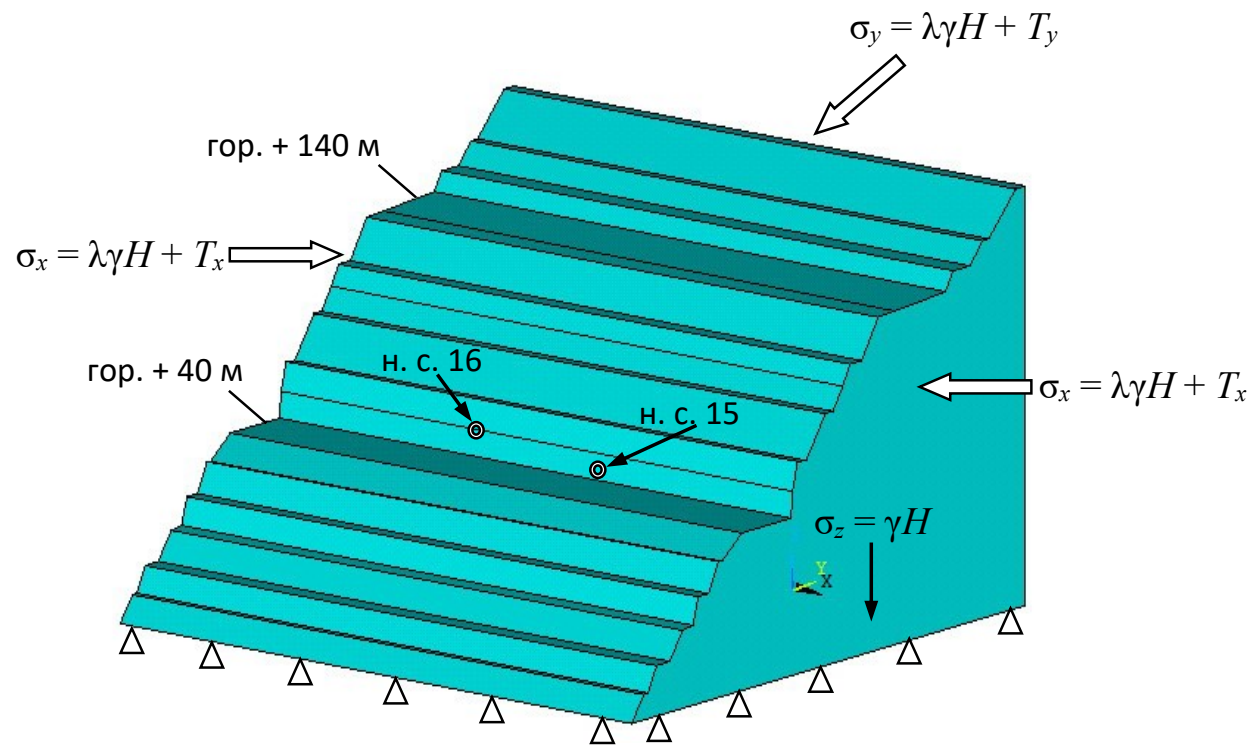

Рис. 3.28. Трехмерная модель исследуемого участка борта карьера

Таблииа 3.1

Сравнение значений измеренных и расчетных напряжений

\begin{tabular}{|c|c|c|c|c|}
\hline \multirow{2}{*}{$\begin{array}{c}\text { Абсолютная отметка } \\
\text { измерительной станции }\end{array}$} & \multicolumn{2}{|c|}{$\begin{array}{c}\text { Значения напряжений } \\
\text { по данным измерений, МПа }\end{array}$} & \multicolumn{2}{|c|}{$\begin{array}{c}\text { Расчетные значения } \\
\text { напряжений, МПа }\end{array}$} \\
\cline { 2 - 5 } & $\sigma_{3 \max }$ & $\sigma_{1 \min }$ & $\sigma_{3 \max }$ & $\sigma_{1 \min }$ \\
\hline+40 м & 13 & 4 & 11 & 6 \\
\hline+94 м & 20 & 4 & 18 & 6 \\
\hline+94 м & 22 & 9 & 18 & 6 \\
\hline
\end{tabular}

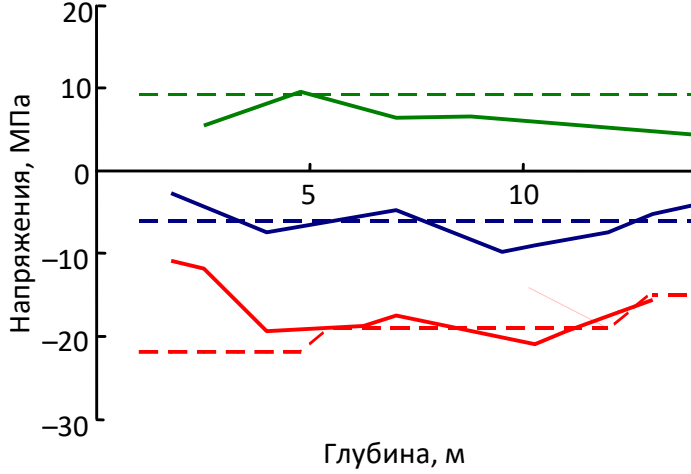

Рис. 3.29. Распределение напряжений по глубине скважины н. с. 15 , гор. +43 м

Выполнен сопоставительный анализ амплитудно-частотных характеристик трасс георадарного зондирования в районе скважины н. с. 15 (горизонт +40 м), а также рассчитанных данных напряженнодеформированного состояния пород на этом участке (рис. 3.30) и на горизонте +140 м, то есть на 100 м выше скважины (рис. 3.31). Как видно из рис. 3.30 и 3.31 , характеры изменения максимальной компоненты квазиглавных напряжений и амплитудночастотных характеристик имеют определенную идентичность с отчетливым выделением от поверхности уступа вглубь массива пород трех контрастных зон. В приконтурной части уступов четко выделяется зона пород мощностью до 4-5 м, практически разгруженных 
от напряжений (разрушенных из-за проведенных буровзрывных работ предыдущего технологического цикла). Далее выделяется зона мощностью до 1020 м со сниженным уровнем напряжений, представляющая собой частично разуплотненные породы. На удалении свыше 10-20 м (для различных участков) и ориентировочно до 40 м (максимальная глубина георадарных определений используемого инструментального комплекса) напряженно-деформированное состояние пород можно идентифицировать как соответствующее исходному состоянию ненарушенного массива.
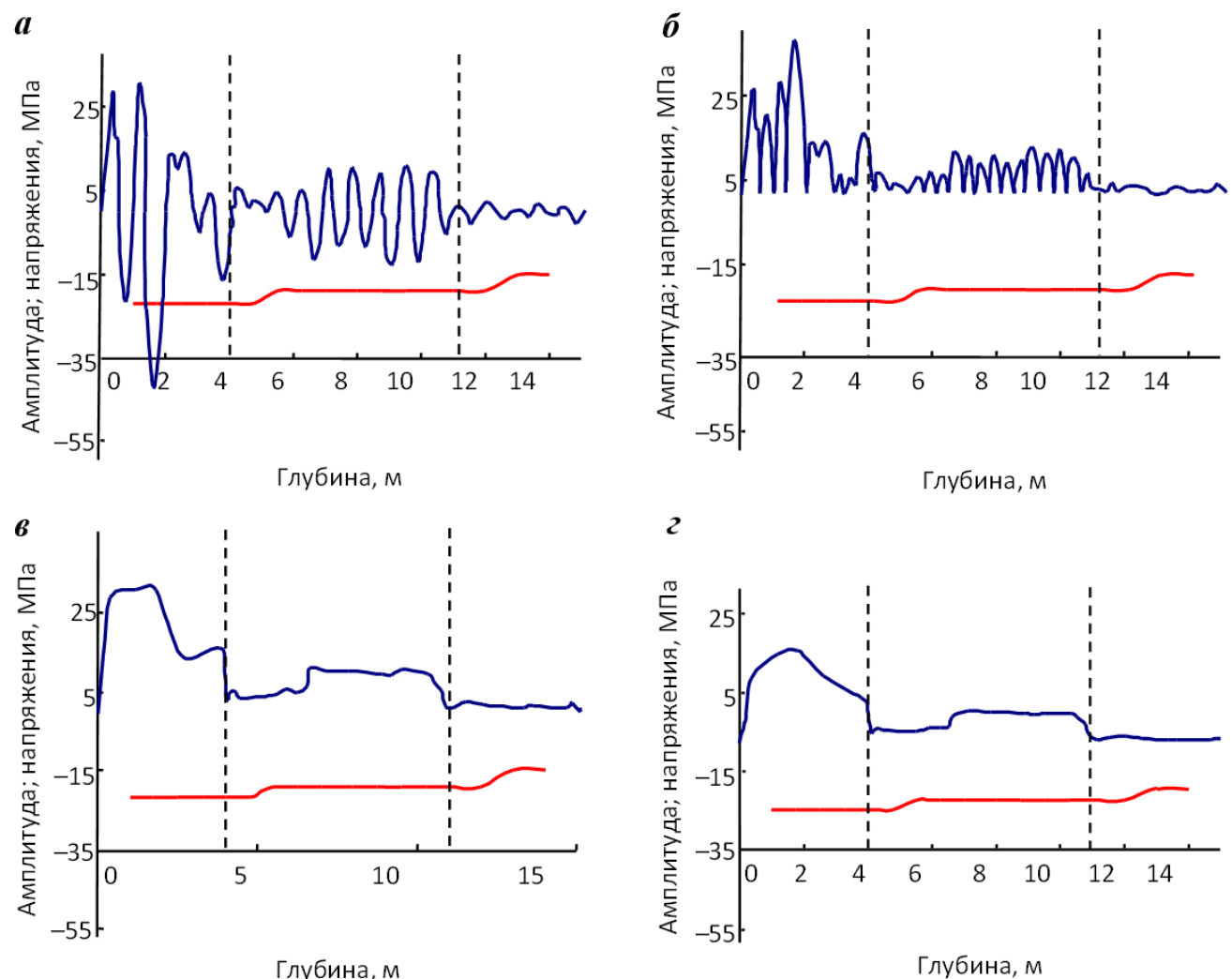

Рис. 3.30. Графики максимальной компоненты квазиглавных напряжений $\sigma_{3}$ и волновых характеристик электромагнитного сигнала на гор. +40 м:

$a$ - амплитудная составляющая; $\sigma$ - модуль амплитуды; 6 - модуль максимальной составляющей; 2 - линейная фильтрация модуля максимальной составляющей

На основе принятого методического подхода выполнены анализ и интерпретация всех радарограмм обработки георадарных экспериментальных исследований с учетом расчетных данных на основе компьютерного моделирования. В результате выявлены общие особенности напряженнодеформированного состояния массива, заключающиеся в формировании субпараллельных контуру карьерной выемки зон с различными электромагнитными характеристиками.

Таким образом, на основе выполненных исследований выявлена взаимосвязь параметров электромагнитного зондирования и напряженного 
состояния пород уступов карьера, что дает основания для применения георадарных технологий для качественной и количественной оценки распределения напряжений в массиве пород при отсутствии измерительных станций.
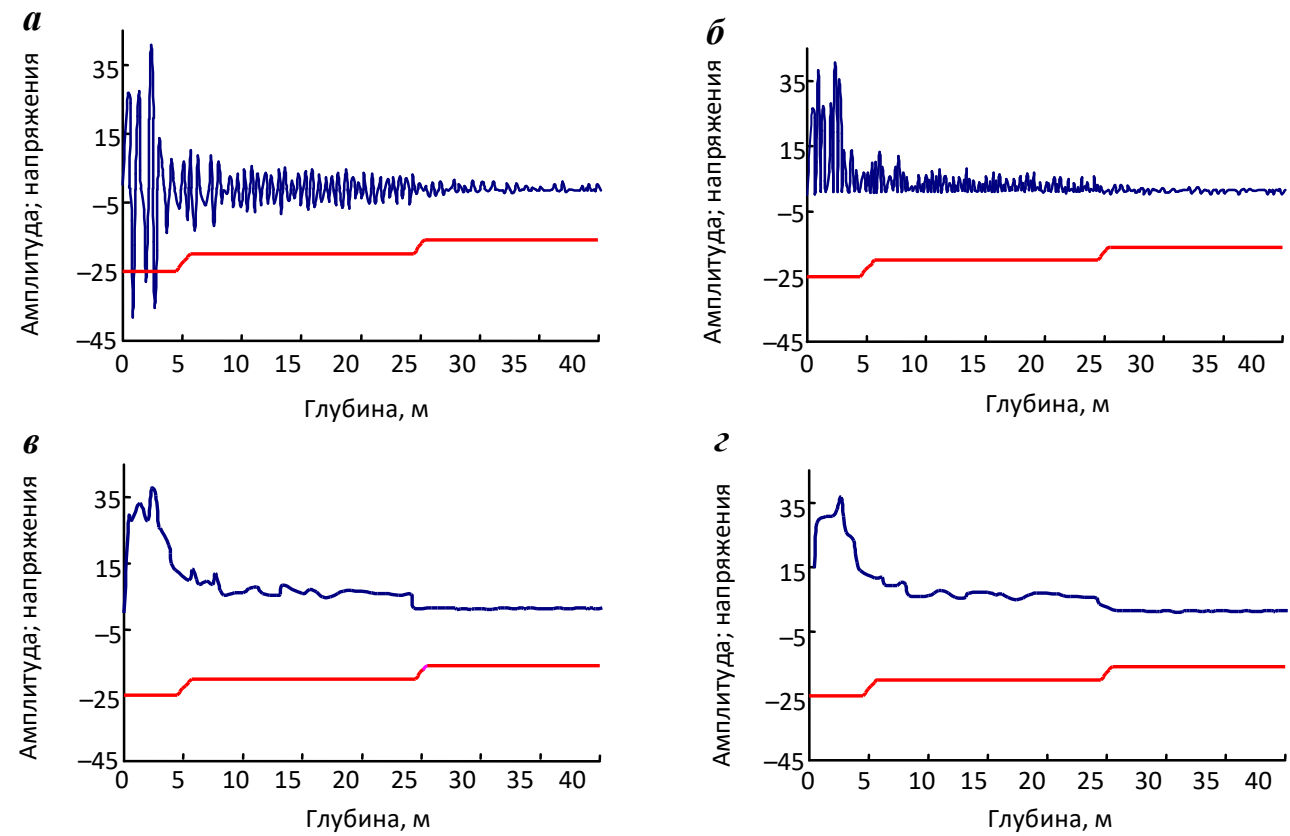

Рис. 3.31. Графики максимальной компоненты квазиглавных напряжений $\sigma_{3}$ и волновых характеристик электромагнитного сигнала на гор. +140 м:

$a$ - амплитудная составляющая; $\sigma$ - модуль амплитуды; в - модуль максимальной составляющей; 2 - линейная фильтрация модуля максимальной составляющей

Принятый методический подход на основе комплексного анализа данных высокочастотного электромагнитного зондирования, натурных измерений и компьютерного моделирования позволил выявить особенности напряженнодеформированного состояния пород уступов карьера «Железный», заключающиеся в формировании субпараллельных контуру карьера зон мощностью $0 \ldots 4$ (5), $4 \ldots 10$ (20) и 10 (20)...40 м. Обнаруженные особенности напряженно-деформированного состояния пород уступов могут быть использованы для оценки их устойчивости и обоснования безопасного ведения БВР и горных работ. 


\section{4. ГЕОРАДАРНЫЕ ИССЛЕДОВАНИЯ НАСЫПНЫХ ГОРНОТЕХНИЧЕСКИХ СООРУЖЕНИЙ}

Большое количество промышленных объектов, в т. ч. гидротехнические сооружения, отнесены к категории опасных и технически сложных объектов, которые требуют регулярных обследований и мониторинга. Одними из таких промышленных объектов являются хвостохранилища с системами ограждающих насыпных сооружений, нарушение устойчивости и функциональности которых может привести к нештатной ситуации в технологической горнопромышленной цепочке или даже к аварии. Оценка надежности, безопасности и устойчивости уступов, склонов и других элементов ограждающих дамб является крайне важной задачей. Поэтому гидротехнические сооружения должны эксплуатироваться в строгом соответствии с нормативными требованиями промышленной безопасности: 117-Ф3 «О безопасности гидротехнических сооружений», ПБ 03438-02 «Правила безопасности гидротехнических сооружений накопителей жидких промышленных отходов», СП 58.13330.2012 «Гидротехнические сооружения» и др. [80-82].

\section{1. Примеры георадарных исследований насыпных сооружений}

Георадиолокационное исследование гидротехнических сооружений заключается в выявлении аномальных зон в их внутренней структуре, которые могут свидетельствовать о наличии неоднородности и/или повышенной фильтрации. Ранее было сказано, что построение скоростных моделей по георадиолокационному профилю в традиционном исполнении «антенна-излучатель» и «антенна-приемник» осуществляется тремя способами:

1) по годографу дифрагированной волны - условно называется способом гипербол (применим, когда на георадарограмме отчетливо проявляются волновые эффекты в виде гипербол);

2) по годографу отраженной волны - способ оценки скоростей может быть реализован по данным многоканальных измерений или одноканальных радаров, работающих с изменяемым расстоянием между передающей и приемной антеннами (построение годографа задержки сигнала);

3) вычисление усредненного значения диэлектрической проницаемости на основе данных «опорных» геологических скважин (так называемый «принцип калибровки»).

В свою очередь, использование двух и более георадарных комплексов, отличающихся способами получения результирующей информации, весьма затратно из-за их высокой аппаратной стоимости. Таким образом, имея в своем распоряжении только экранированные антенны, где приемник и передатчик находятся в едином корпусе, возможно проведение только профилирования, следовательно, вычисление скоростей по разрезу крайне затруднительно (по годографу дифрагирующей волны), а в ряде случаев и невозможно (из-за их отсутствия). В случае применения раздельных антенн для излучения и приема сигнала возможно проведение точечного зондирования (по годографу отраженной волны) с получением значений скоростей в данной точке 
(но получение этих значений по профилю крайне трудозатратно). Данный подход используется только для получения примерных данных о скоростях на исследуемом участке или для сопоставления данных на эталонном и аномальном участках.

Результаты зондирования гидротехнических сооружений так же, как и для скальных пород, обрабатывались с использованием специализированных компьютерных программ RadExplorer и ГЕОРАДАР-ЭКСПЕРТ, раздельно интерпретировались, а затем выполнялся комплексный анализ полученных данных в пространственно-глубинной взаимосвязи $[67,83,84]$.

На рис. 4.1 представлен фрагмент радарограммы № 1, полученной в результате стандартной обработки георадиолокационных данных зондирования ограждающей дамбы хвостохранилища горнопромышленного предприятия, c применением программы RadExplorer. Детальный анализ амплитудночастотных характеристик электромагнитных трасс радарограммы позволил выявить структурные неоднородности в слагающих дамбу грунтах и локализовать уровень грунтовых вод.

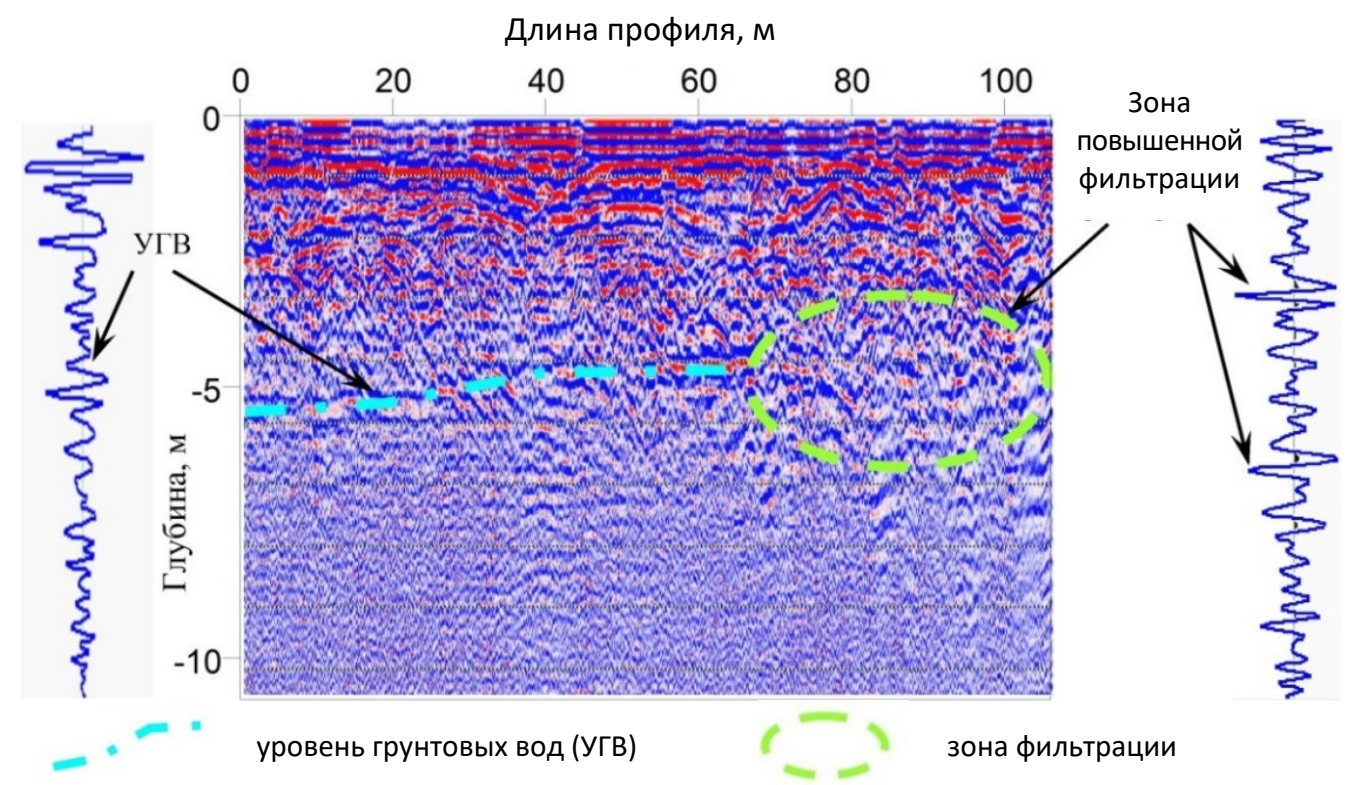

Рис. 4.1. Радарограмма № 1 зондирования ограждающей дамбы хвостохранилища, обработанная и интерпретированная в программе RadExplorer

Прохождение сигнала в приповерхностном слое на глубину до 1 м характеризуется начальной максимальной амплитудой сигнала. Дальнейшее изменение амплитудных характеристик электромагнитного сигнала, а именно их уменьшение, связано с изменением физико-механических свойств грунтов, слагающих дамбу, с глубиной происходит постепенное затухание сигнала. Скачкообразное изменение формы и интенсивности сигнала свидетельствует о его прохождении через границу с изменением диэлектрических свойств грунтов, обусловленных их различным водонасыщением. Так, на интервале 0-60 м профиля четко прослеживается уровень грунтовых вод, который локализуется на глубине 4,8-5,2 м от дневной поверхности. В свою очередь, 
увеличение (всплеск) амплитуды сигнала на $10 \%$ от общего значения на участке 65-100 м профиля явно указывает на различие здесь свойств грунтов в дамбе (зона повышенного водонасыщения грунтов).

Таким образом, выполненная обработка и интерпретация радарограммы георадиолокационного зондирования ограждающей дамбы хвостохранилища с использованием программы RadExplorer позволяет получить картину eе водонасыщенного состояния в общем виде.

На рис. 4.2 представлен фрагмент профиля георадиолокационного зондирования этой же ограждающей дамбы, построенный с использованием технологии поля обратного рассеивания программы ГЕОРАДАР-ЭКСПЕРТ. Как видно из рисунка, такая обработка данных позволяет детализировать радарограмму, что дает возможность увидеть даже незначительные изменения электрофизических свойств дамбы (изменение скорости прохождения электромагнитной волны и диэлектрической проницаемости грунтов). Сопоставительный анализ значений данных пьезометров об УГВ и скорости электромагнитной волны в их окрестностях позволил определить интервал изменения значений скорости $(8,017-8,165$ cм/нс) и значений диэлектрической проницаемости $(14,0-13,5)$, соответствующих установившемуся в теле дамбы уровню воды на момент измерений в окрестности пьезометров. В расположенном выше УГВ сухом и уплотненном грунте значения скорости изменяются в интервале 8,170-9,672 см/нс (диэлектрическая проницаемость, соответственно, от 13,5 до 9,62). Снижение скорости электромагнитной волны ниже УГВ обусловлено повышением диэлектрической проницаемости, что, в свою очередь, связано с увеличением воды в порово-скелетном пространстве дамбы и соответствующим водонасыщением грунтов.

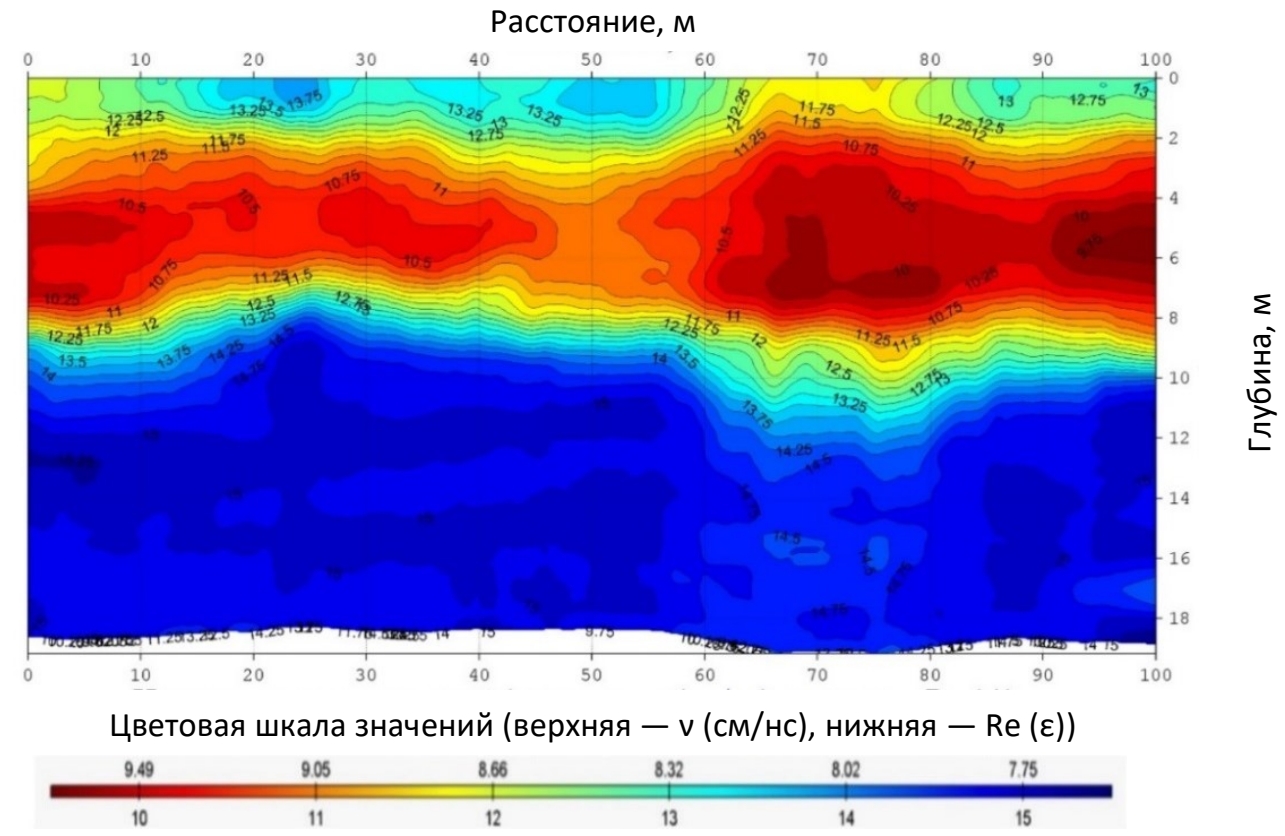

Рис. 4.2. Обработанная и интерпретированная в программе ГЕОРАДАР-ЭКСПЕРТ радарограмма зондирования ограждающей дамбы 
Таким образом, области радарограммы со значениями скорости менее $8,1 \mathrm{~cm} / \mathrm{нc}$ (среднее арифметическое для определенного интервала) соответствуют водонасыщенным участкам грунтов, которые требуют повышенного внимания при проведении мониторинга. В частности, в интервале 10-60 м профиля выделяются приповерхностные зоны (на глубину до 1,5 м), что соответствует увлажнению (намоканию) грунтов поверхностными водами (дождь, снеготаяние).

На рис. 4.3 представлена радарограмма стандартной обработки георадиолокационных данных зондирования ограждающей дамбы хвостохранилища другого горнопромышленного предприятия, на которой, по данным волновой картины, выделены уровень грунтовых вод и зоны структурной неоднородности.

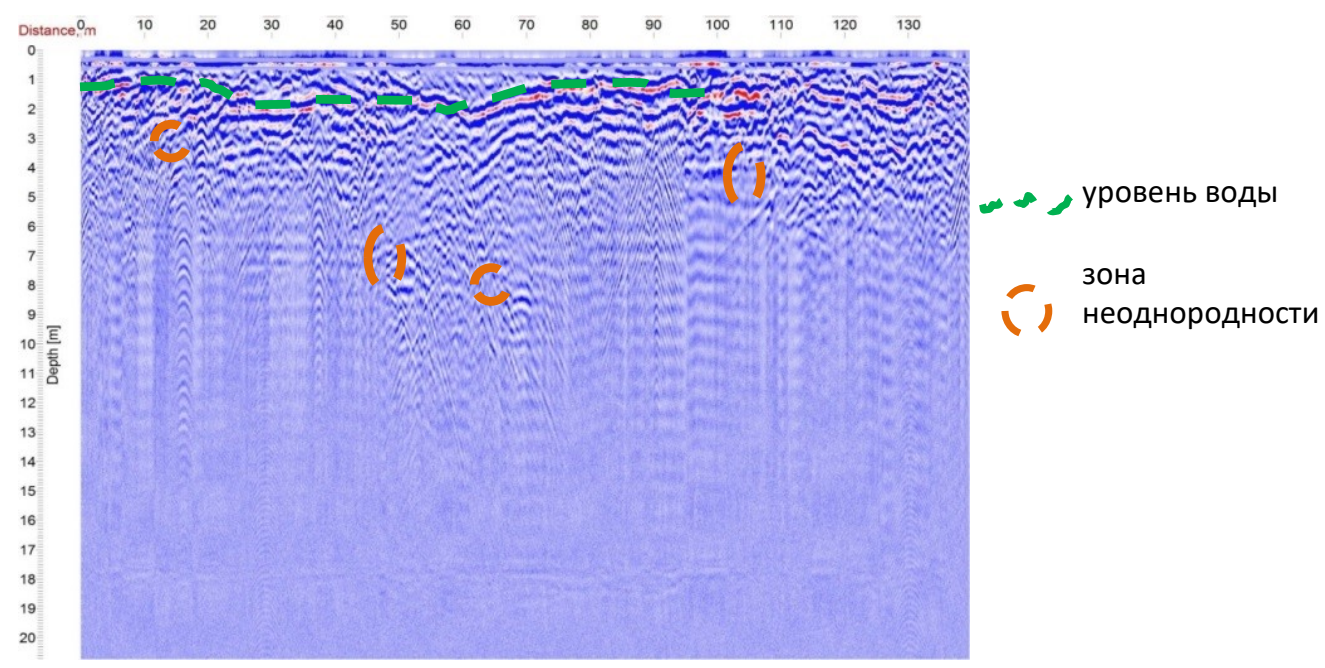

Рис. 4.3. Радарограмма № 2 зондирования ограждающей дамбы, обработанная и интерпретированная в RadExplorer

Интерпретация результатов выполненных исследований ограждающей дамбы (радарограмма № 2, рис. 4.4, a) позволяет сделать следующие выводы. Приповерхностная зона грунтов дамбы до отметки 1-2 м характеризуется начальной высокой скоростью электромагнитной волны $V-9,2-9,5$ см/нс (плотные сухие грунты) с дальнейшим относительно резким ее понижением до $8,02-7,75$ см/нс на отметке 2-7 м, что обусловлено, скорее всего, увеличением влажности грунтов.

Выделяются две водонасыщенные зоны на интервалах расстояний 0-25 и 60-100 м и на глубинах 2-7 м, которые в целом коррелируют с данными анализа амплитудно-частотных характеристик сигнала на рис. 4.3.

Интерпретация анализируемых результатов выполненных исследований ограждающей дамбы (радарограмма № 3, рис. 4.4, б) позволяет сделать следующие выводы. Приповерхностная зона грунтов дамбы до глубины $1,5-2$ м характеризуется начальной высокой скоростью электромагнитной волны $V-$ 9,2-9,5 см/нс (плотные сухие грунты), с дальнейшим относительно резким ее понижением локально до 8,32-7,75 cм/нс на глубине 2-7 м, что обусловлено, скорее всего, увеличением влажности грунтов. 

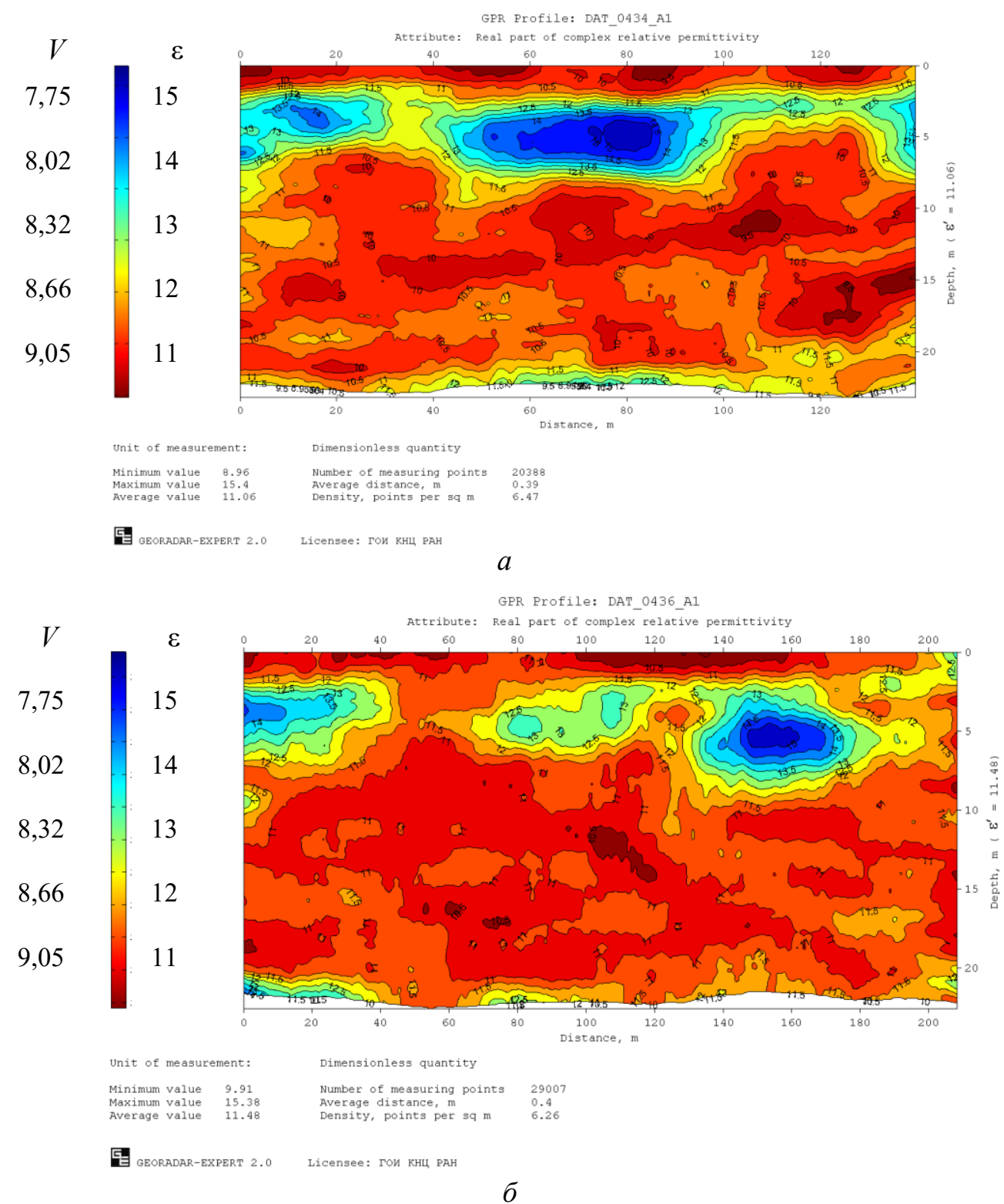

Рис. 4.4. Радарограммы № 2 (a) и № 3 (б) зондирования ограждающей дамбы, обработанные и интерпретированные в программе ГЕОРАДАР-ЭКСПЕРТ

Выделяются три водонасыщенные зоны на интервалах расстояний 0-25 м, 80-110 и 140-170 м, на глубине 2-7 м, которые в целом коррелируют с данными анализа амплитудно-частотных характеристик сигнала рис. 4.5.

В результате комплексного анализа данных результирующего электромагнитного сигнала (амплитуда, фаза, период), параметров волнового поля (скорость распространения электромагнитных волн), георадарного зондирования и визуального обследования уступов дамбы установлены параметры, обеспечивающие 
идентификацию водонасыщенных зон грунтового гидротехнического сооружения георадиолокацией, которые использовались для дальнейшего анализа и интерпретации всех радарограмм (рис. 4.6).

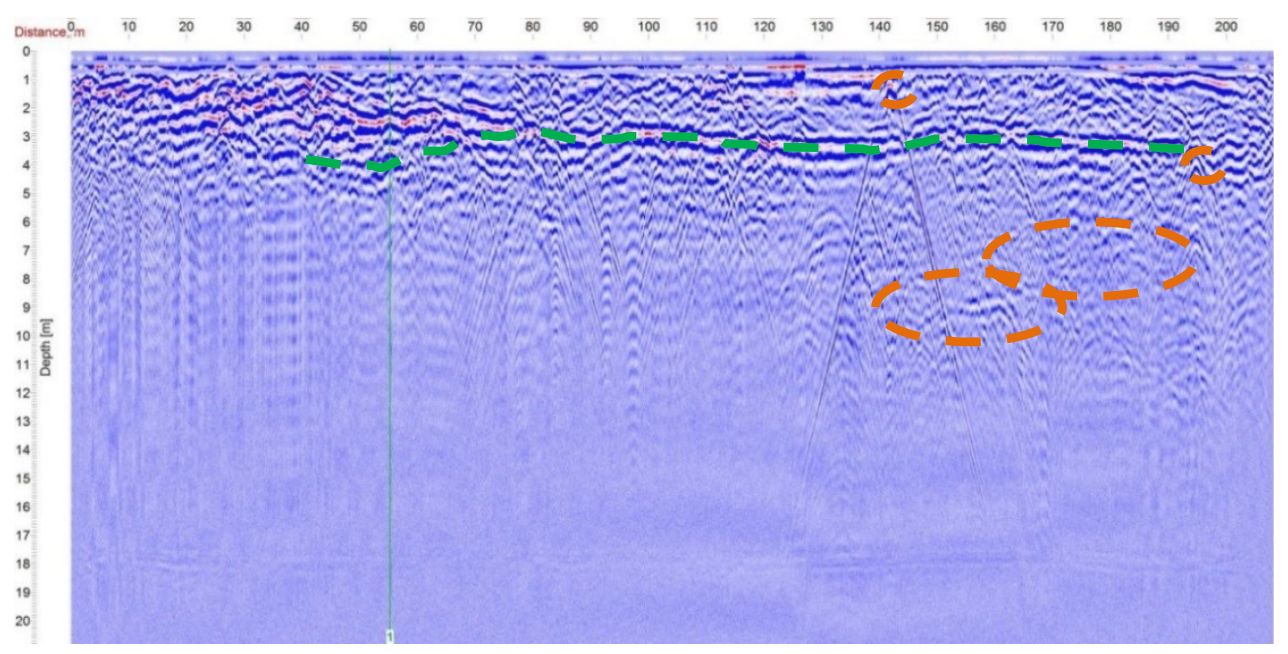

Рис. 4.5. Радарограмма № 3 зондирования ограждающей дамбы, обработанная и интерпретированная в программе RadExplorer

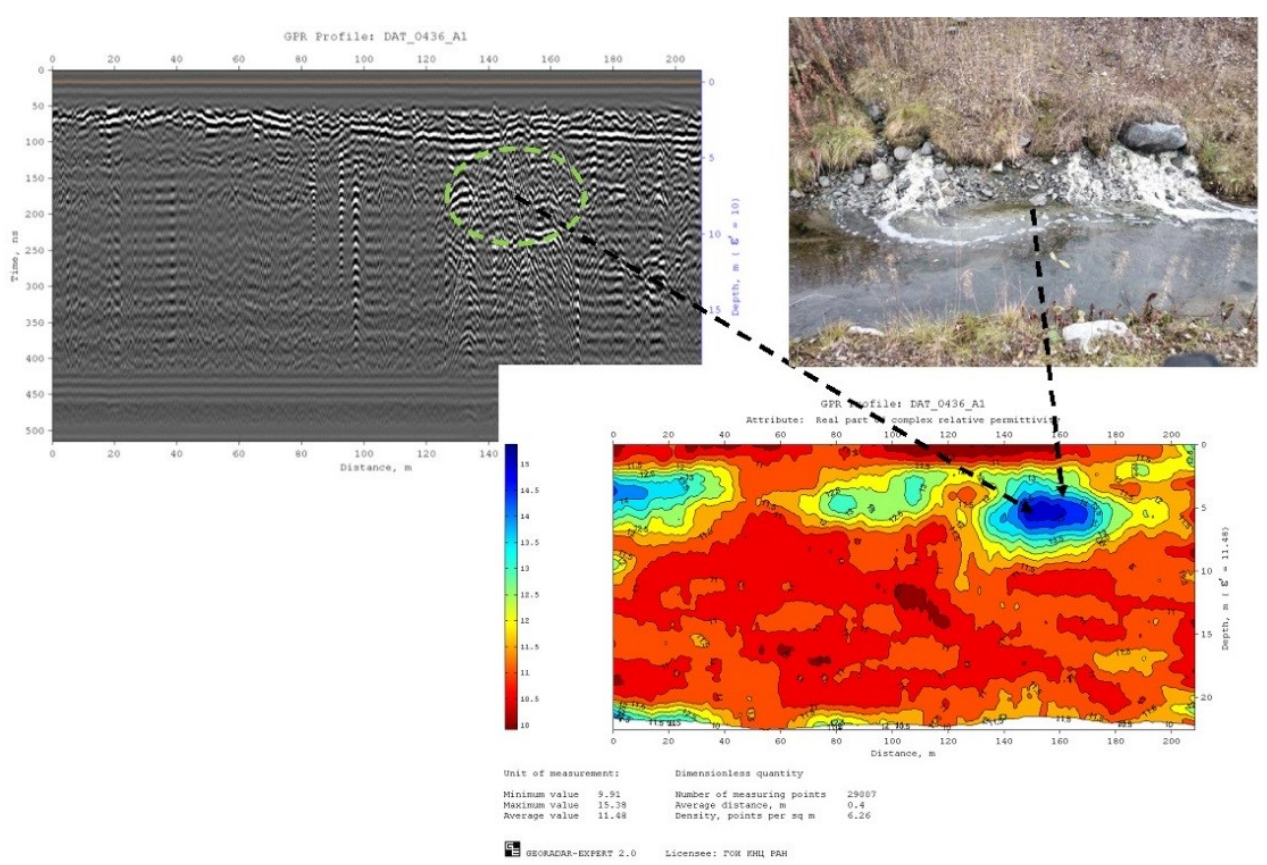

Рис. 4.6. Комплексный анализ данных георадарного зондирования (слева — параметры амплитудной формы сигнала, справа внизу — параметры волнового поля, справа сверху визуальное обследование) ограждающей дамбы (радарограмма № 3)

В качестве недостатка все же стоит отметить отсутствие заверенных зависимостей: параметры волнового поля - степень водонасыщения грунтов, 
которые можно было бы получить с использованием комплексирования геофизических методов, например, георадарного и сейсмического.

\section{2. Применение георадарных исследований при решении вопросов перемещения отвалов пород для расширения карьера}

Вследствие многолетней добычи апатитовой руды рудником «Центральный» АО «Апатит» на близлежащих горных склонах плато Расвумчорр образовались значительные объемы отвалов пустых пород (млн т). При этом основной задачей в течение практически тридцати лет было решение проблемы обеспечение их устойчивости с учетом того обстоятельства, что в отвалах было значительное количество смерзшегося снега и снежно-породных конгломератов [85]. В настоящее время развитие карьера предопределило вовлечение в эксплуатацию запасов руд, расположенных непосредственно под отвалами пород. В связи с этим было принято решение о перемещении породных отвалов за пределы расширяемого контура карьера, однако это оказалось достаточно сложной задачей, так как отвалы, представляющие собой смесь кусков пород различной величины и снежно-ледяных включений, в условиях практически всего времени отрицательных здесь температур трансформировались в снежноледяные породные конгломераты.

Применение для этих условий стандартных БВР показало их достаточно низкую эффективность в части отбиваемой массы (развала пород). На некоторых участках необходимого дробления не происходило: подповерхностные снежнопородные конгломераты после отбойки представляли собой негабариты, плохо поддающиеся экскавации. Для целей оптимизации БВР необходимо было опережающее знание о наличии и размерах этих конгломератов, которое можно было получить на основе применения малозатратных оперативных геофизических методов, в частности, георадиолокационного зондирования [39, 45, 86-90], достаточно успешно применяемого при решении различного рода горнотехнических задач на горных предприятиях ЗЧРСА [57-60, 66, 67].

Прежде чем приступить к георадиолокационному зондированию перемещаемых отвалов, авторы проанализировали результаты исследований, выполненных специалистами Горного института КНЦ РАН по проблеме устойчивости заснеженных отвалов на горных склонах $[85,91,92]$. Был выявлен ряд геотехнических особенностей отвалообразования на горных склонах плато Расвумчорр, относительная высота которого достигает 400-500 м:

- гранулометрический состав раздробленного породного массива, находящегося в отвалах, изменяется в довольно широких пределах - от 0-2 до 1000-1500 мм - и распределяется в удельном отношении следующим образом (рис. 4.7). При этом средневзвешенная величина диаметра куска $d_{c}$ породы составила около 242 мм и была рассчитана по формуле

$$
d_{\mathrm{c}}=\sum_{i=1}^{n} \frac{A_{i} \cdot \gamma_{i}}{100},
$$

где $A_{i}$ - среднее арифметическое значение размера отверстий сит, ограничивающих данный класс крупности, мм; $\gamma_{i}$ - выход класса крупности, \%; $n$ - число классов крупности; 
- во время отсыпки породы на горные склоны происходило скатывание ее кусков и естественное распределение в зависимости от их массы и размера: крупность кусков к подножию возрастала, а мелкие фракции располагались в верхней части отвала, при этом в отсыпаемые отвалы зачастую попадали значительные объемы снега как непосредственно в виде осадков и ветровых наносов, так и в перевозимых породах. Так, за период с 1968 по 1973 гг. в отвалы № 8 и № 9 было отсыпано 13,4 млн м³ вскрышной породы (примерно 36 млн т). Оценка снегонаполнения, по многолетним метеорологическим наблюдениям, позволила установить, что в течение этого периода в отвалы попало от 3,5 до 5,0 млн м ${ }^{3}(1,0-1,5$ млн т) снега [85]. Этот снег, погребенный в отвальной породе, заполнил ее пустоты, спрессовался под действием ее веса до плотности фирнового льда $\left(0,7-0,8 \mathrm{~T} / \mathrm{M}^{3}\right)$ и сцементировал ее, превратив из сыпучей среды в конгломерат породы и снега;

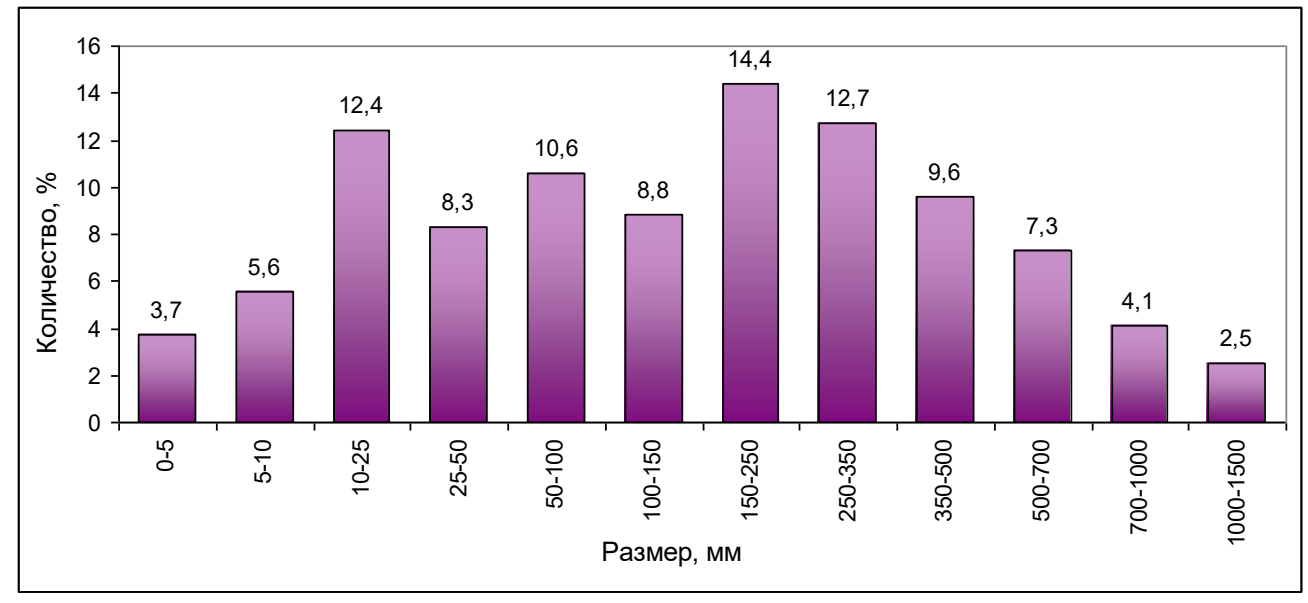

Рис. 4.7. Гранулометрический состав пород в отвале

- общий объем включенного в отвальные породы снега может достигать 30 \%. Наибольшая заснеженность приурочена к участкам отвалов, где перерывы в отсыпке породы достигали одного и более месяцев. Оценка снегосодержания в отвалах показала, что в слоях зимней отсыпки средняя заснеженность (весовая) достигала 14-20\%, а объемная — от 7 до 77 \% и более (табл. 4.1) [85]. При этом мощность снежно-породного конгломерата могла составлять от нескольких метров до 50-60 м (рис. 4.8);

Таблица 4.1

Средняя заснеженность отвальной породы [по: 85]

\begin{tabular}{|c|c|c|c|c|c|}
\hline $\begin{array}{c}\text { Номер } \\
\text { отвала }\end{array}$ & Годы & Объемная, \% & $\begin{array}{c}\text { Номер } \\
\text { отвала }\end{array}$ & Годы & Объемная, \% \\
\hline $1-\mathrm{a}$ & $1970-1972$ & $38,5-46,2$ & $8-6$ & $1967-1972$ & $15,4-38,5$ \\
\hline 4 & $1965-1972$ & $38,5-154,0$ & $9-\mathrm{a}$ & $1969-1972$ & $38,5-77,0$ \\
\hline $6-\mathrm{a}$ & $1966-1971$ & $7,7-53,9$ & & & \\
\hline
\end{tabular}


- крупнокусковатый материал отвалов имел высокий коэффициент пустотности и, следовательно, фильтрации, в то время как мелкие фракции отвальной породы, преобладающие в верхней части отвала, перемешиваясь со снегом, образовывали снежно-породный конгломерат, физико-механические свойства которого существенно отличаются от заснеженной крупнокусковатой породы и обладают большой изменчивостью при повышении температуры, особенно вблизи значения $0{ }^{\circ} \mathrm{C}$ и в момент вытаивания снега;

- поле отрицательных температур простирается по вертикали на глубину не менее 100 м, что исключает приток тепла от подстилающей поверхности, но обеспечивает постоянный приток холода. Вследствие теплоносителей (дождь, талые воды, нагрев) отвалы прогревались от поверхности на глубину не более 3-5 м, а в холодные годы прогревания вообще не происходило;

- при превышении объема пустот объемом льда (льдистость более 30 \%) ранее разделенные породными кусками участки льда объединяются в сплошной каркас и разделяют, в свою очередь, куски породы, которые как бы взвешены во льду. Это обусловливает связность отвальной массы и ее вязкопластические свойства, которые и сказываются при проведении отбойки отвальных пород.

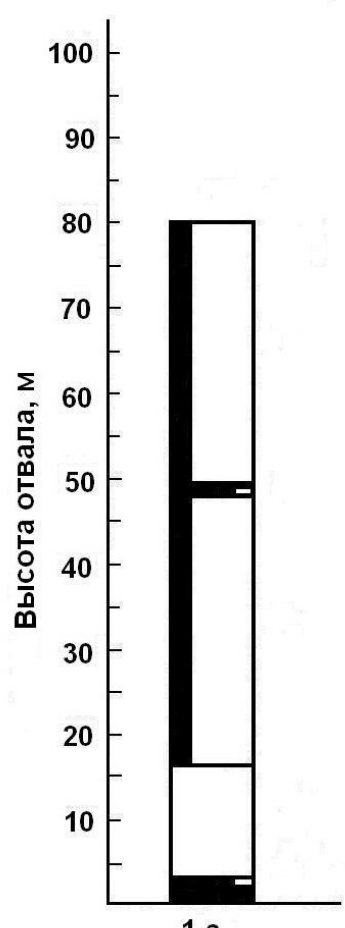

1-a

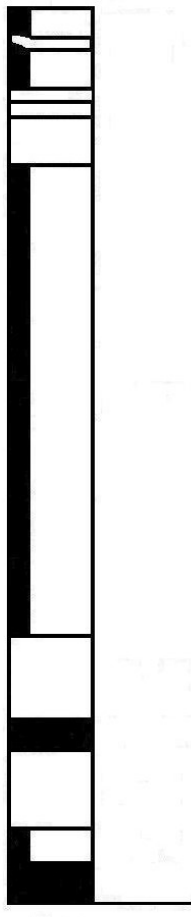

6-a

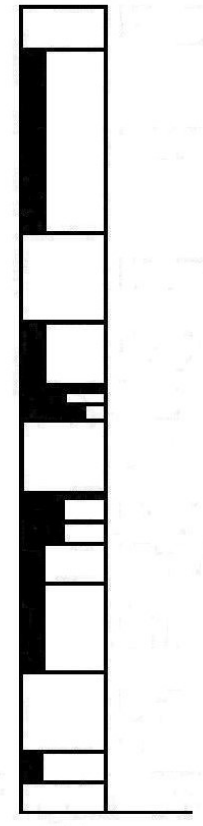

8-6
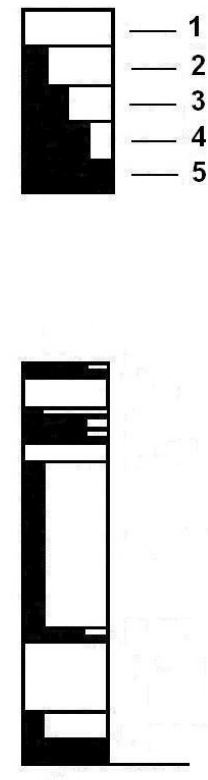

9-a

Рис. 4.8. Вертикальная стратиграфия и степень заснеженности отвальной породы [85]: 1 - порода без снега; 2 - частичное заполнение пор снегом; 3 - заполнение целиком пор неуплотненным снегом; 4 - заполнение целиком пор двукратно уплотненным снегом; 5 - переуплотненный снег превышает по объему поры

Эти геотехнические особенности и предопределили сложность БВР при перемещении горных отвалов. Поэтому основной целью проведения георадарного зондирования перемещаемых отвальных пород была оценка 
подповерхностного содержания снега и льда в отвалах, а также выявление и оконтуривание снежно-ледяных линз и нижней границы приповерхностных снежно-породных конгломератов.

Для проведения контрольных георадиолокационных исследований на отвалах пород была подготовлена относительно горизонтальная площадка площадью около 500 м². На ней было выполнено профилирование по сетке с расстоянием 5 м между профилями, при этом суммарная длина продольных и поперечных профилей составила 1340 м.

Измерения производились георадаром RamacGPR/X3M (экранированная антенна 100 МГц) с заданной глубиной зондирования до 20 м и автоматической записью результирующих электромагнитных сигналов в файл. Для обработки файловых георадиолокационных данных применялся специализированный программный продукт RadExplorer, a исходными данными для обработки служили параметры диэлектрической проницаемости компонентов системы породных отвалов (табл. 4.2).

Таблицุа 4.2

Исходные данные для обработки результатов георадиолокационного зондирования породных отвалов

\begin{tabular}{|l|c|c|}
\hline Исследуемая среда & $\begin{array}{c}\text { Относительная } \\
\text { диэлектрическая } \\
\text { проницаемость } \varepsilon\end{array}$ & $\begin{array}{c}\text { Скорость прохождения } \\
\text { электромагнитной } \\
\text { волны, см/нс }\end{array}$ \\
\hline Воздух & 1 & 30 \\
\hline Вода & 81 & 3,3 \\
\hline Лед & $3-4$ & $15,0-17,3$ \\
\hline Апатит & $5-6$ & $11,3-13,4$ \\
\hline Нефелин & $7-8$ & $10,0-11,1$ \\
\hline Глина & $4-16$ & $7,4-15,0$ \\
\hline Песок & $4-30$ & $5,5-15,0$ \\
\hline Моренные суглинки & $9-25$ & $6,0-10,0$ \\
\hline
\end{tabular}

В результате применения специальных процедур обработки $[10,39]$ получены волновые картины-радарограммы, отображающие подповерхностную структуру отвалов на глубину до 15-20 м. Интерпретация радарограмм на основе анализа изменчивости амплитуд сигналов позволила выделить снежно-породные конгломераты, участки льда и локализовать их нижнюю границу (пример интерпретированной радарограммы представлен на рис. 4.9).

Для целей визуализации и наглядного представления результатов георадиолокационного зондирования была построена трехмерная цифровая модель верхней части породного отвала с достаточно высоким уровнем детализации, необходимым для решения задач оптимизации параметров БВР в части расположения и глубины буровых скважин и степени их заряжения ВВ. На первом этапе выполнена графическая интерпретация георадиолокационных данных - построение цифровой модели поверхности и ее визуализация, на втором - с использованием 3D-технологий создана объемная модель с информацией о подповерхностной структуре породного отвала (рис. 4.10). 
Основой для построения 3D-модели являлись данные с 23 обработанных радарограмм по поперечным и продольным профилям, представляющим собой трехмерную матрицу координат в узловых точках (пересечение профилей по сетке 5 м).

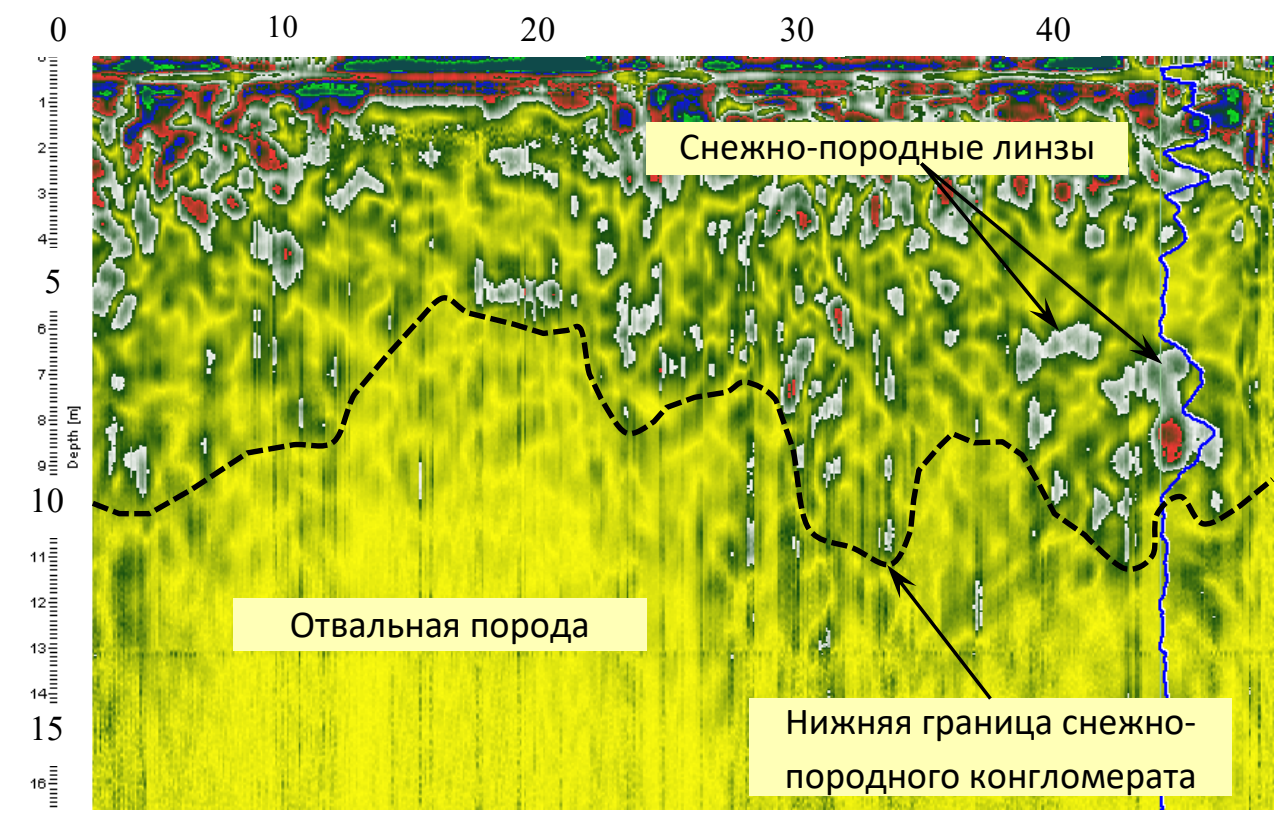

Рис. 4.9. Фрагмент радарограммы с выделением приповерхностного снежно-породного конгломерата и снежно-ледяных линз

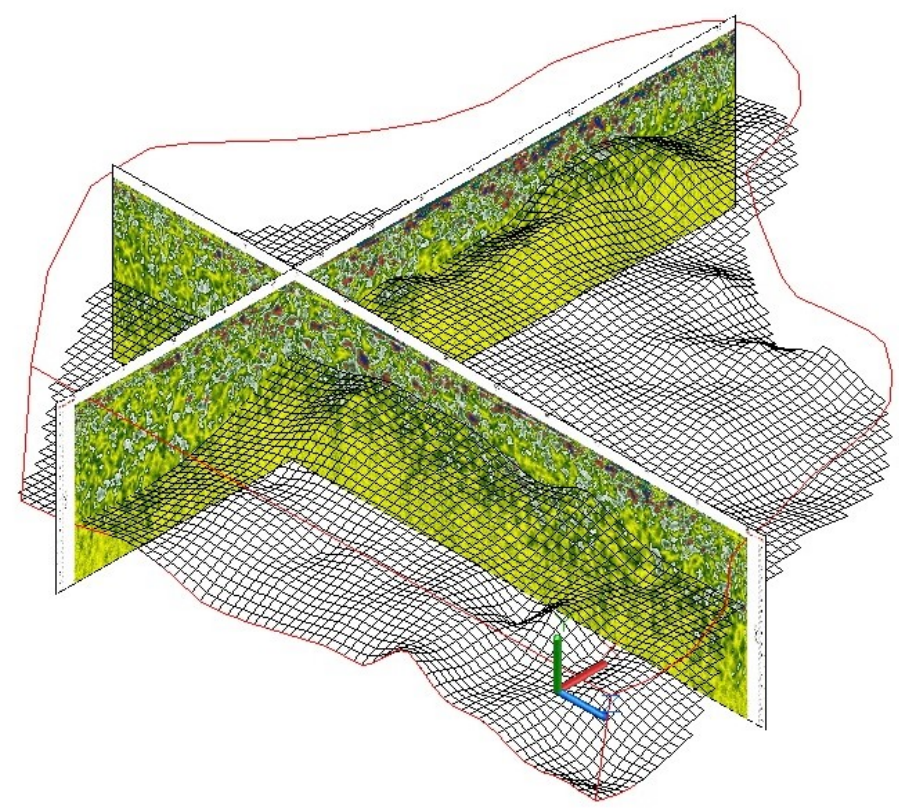

Рис. 4.10. 3D-модель структуры участка отвалов пород по результатам георадиолокационного зондирования 
Комплексный анализ радарограмм, цифровых поверхностей и 3D-модели позволяет сделать следующие выводы о структуре отвалов на участке георадиолокационного исследования:

- верхняя часть породного отвала представляет собой снежно-породный конгломерат, простирающийся от дневной поверхности вглубь отвала до 3-4 м в центре площадки, до 7-8 м - на юго-восточной ее части и до 13-14 м на северной. Ниже, по данным зондирования - до глубины 20 м, располагается отвальная порода с достаточно равномерным гранулометрическим составом и низким содержанием снега и льда;

- снежно-породный конгломерат состоит из уплотненного дисперсного снега, в который «впаяны» куски породы размером от первых сантиметров до 0,5 м.

Выполненный системный анализ многолетних исследований по породным отвалам на руднике «Центральный» АО «Апатит» позволил выявить ряд геотехнических особенностей, создающих затруднения при проведении БВР для перемещения отвалов за пределы расширяемого карьера.

По результатам георадиолокационных определений построены и интерпретированы радарограммы - вертикальные разрезы, а также цифровая поверхность нижней границы и 3D-модель структуры снежно-породного отвала. Установлено, что верхняя часть отвалов представляет собой единый снежнопородный конгломерат, простирающийся от поверхности на глубину до 3 м в центральной части и до 8-10 м на краевых частях (в северной части на глубину до 14 м). Ниже выделяемого конгломерата, по данным георадиолокационного зондирования, - на глубину до 20 м - находится равномерно распределенная отвальная порода с низким содержанием снега и льда. Применение георадиолокационного зондирования позволило получить детализированную информацию (в цифровом поверхностном и объемном отображении, проекции изолиний нижней границы снежно-породного конгломерата на горизонтальную поверхность) подповерхностной структуры отвалов, что предоставляет конкретную количественную основу для планирования и проведения буровзрывных работ для качественного дробления перемещаемых отвалов.

\section{3. Комплексирование георадарных исследований и визуального обследования насыпного сооружения}

Нормативные документы в области промышленной безопасности насыпных гидротехнических сооружений предписывают проведение регулярного визуального обследования всех элементов сооружения. Помимо преимуществ данного метода: отсутствие необходимости в дорогостоящем оборудовании, возможность оперативно оценить состояние сооружения и др. - существует и ряд недостатков. Один из недостатков визуального метода - невозможность точной интерпретации и параметризации явлений в теле сооружения. Например, при обнаружении локального выхода воды на поверхность гидротехнического сооружения зачастую сложно оценить его природу, источник, геометрические параметры области с нарушенными фильтрационными свойствами, а также динамику развития процесса. Этот недостаток метода визуального обследования может нивелироваться за счет его комплексирования с другими методами, например геофизическими. 
Использование косвенных геофизических методов обследования позволяет получать оперативную информацию о структурных особенностях сооружения и степени водонасыщенности слагающих их грунтов. Существование большого количества методов геофизики свидетельствует об отсутствии какогото одного стандартного метода, способного обеспечить оперативное и качественное получение требуемой информации о структуре насыпных сооружений. Опыт применения для изучения физических свойств пород месторождений Урала, Сибири, Дальнего Востока и ЗЧРСА показывает, что неразрушающее подповерхностное георадарное обследование может эффективно использоваться для изучения насыпных сооружений, включая гидротехнические.

Вместе с тем основным недостатком метода является сложность интерпретации полученных данных $[83,93]$, но все же указанная проблема может быть устранена за счет комплексирования методов георадарного и визуального обследования. Важной и отличительной особенностью комплексирования этих методов можно назвать возможность непосредственной привязки наблюдаемых геофизических полей к текущей ситуации на гидротехническом сооружении (деформации, зоны водопроявления и т. д.) [94].

В связи с этим показано комплексирование натурного визуального и георадарного методов для выявления и ограничения локальных нарушений фильтрационных процессов в теле насыпного гидротехнического сооружения.

Стоит также отметить, что в настоящее время основными тенденциями при проведении инженерных изысканий в части геофизических исследований гидротехнических сооружений является применение цифровых технологий для повышения скорости обработки, информативности и надежности получаемых данных. Цифровизация как георадарных, так и визуальных (за счет систематизации, обработки и анализа цифровых фотоснимков) данных также позволяет создать базу для успешного комплексирования данных методов.

Первый цикл комплексных наблюдений визуальным и георадарным методами был выполнен в 2017 г. на наблюдательном полигоне насыпной дамбы хвостохранилища для локализации зон водонасыщения и намокания грунтов. По данным визуальных наблюдений был выделен участок, на котором обнаружен выход фильтрующейся воды на поверхность полки, кроме того, там замечено локальное проседание поверхности полки дамбы (рис. 4.11).

Выход на поверхность дамбы фильтрующейся воды и локальное деформирование поверхности полки могут быть индикаторами наличия на данном участке локального нарушения фильтрационной устойчивости дамбы [95]. В качестве подтверждения наличия там указанного нарушения может служить инфильтрация скапливающейся на поверхности полки воды в зону деформации (рис. 4.12).

При этом инфильтрация скапливающейся на полке дамбы воды происходит без ее накопления в зоне деформации, что может свидетельствовать о наличии в теле сооружения полостей, по которым вода передается на нижележащее поле хвостохранилища. Эти полости, вероятно, появились в результате локальных нарушений фильтрационных процессов, которые постепенно развивались во времени и привели к наблюдаемой локальной деформации поверхности полки (рис. 4.11). Визуальный осмотр сооружения позволил идентифицировать участок, на котором наблюдаются признаки локального нарушения фильтрационных свойств дамбы, при этом развитие 
данного процесса уже привело к деформированию поверхности дамбы. Таким образом, можно предположить, что дальнейшее развитие данного процесса может угрожать устойчивости как исследуемого гидротехнического сооружения, так и хвостохранилища в целом. Поэтому целесообразно принять меры, направленные на изучение подповерхностной структуры сооружения и процессов, в нем происходящих, геофизическими и другими методами.

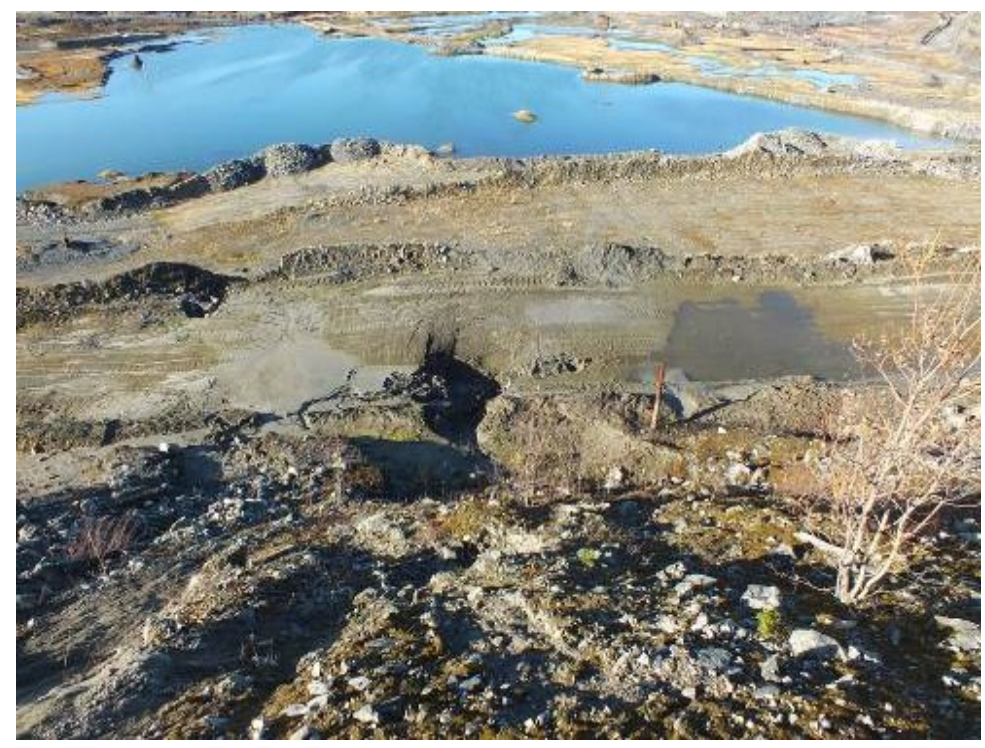

Рис. 4.11. Участок обследуемой ограждающей дамбы хвостохранилища (вид сверху)

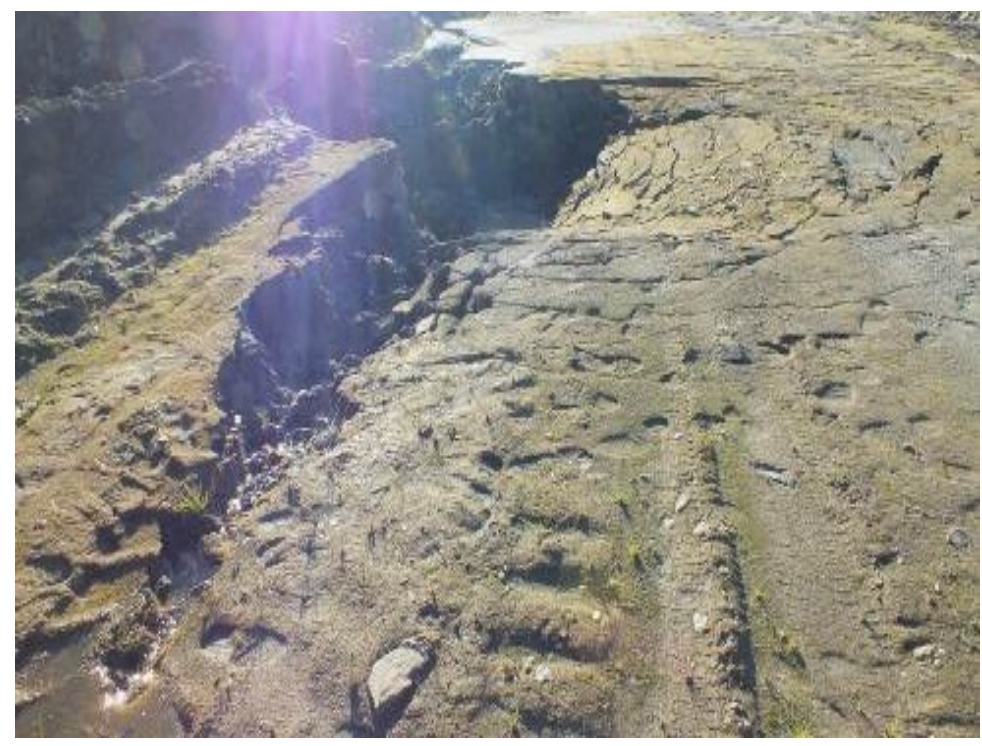

Рис. 4.12. Инфильтрация воды в область деформации ограждающей дамбы

В связи с этим было проведено георадарное обследование вышележащей полки дамбы, в результате которого получены радарограммы, цифровая 
обработка которых позволила получить схему распределения параметра $V$ скорости прохождения электромагнитной волны. Основные результаты выполненных исследований для геофизического метода представлены в виде радарограмм скорости электромагнитной волны $V$ за октябрь и ноябрь (рис. 4.13).

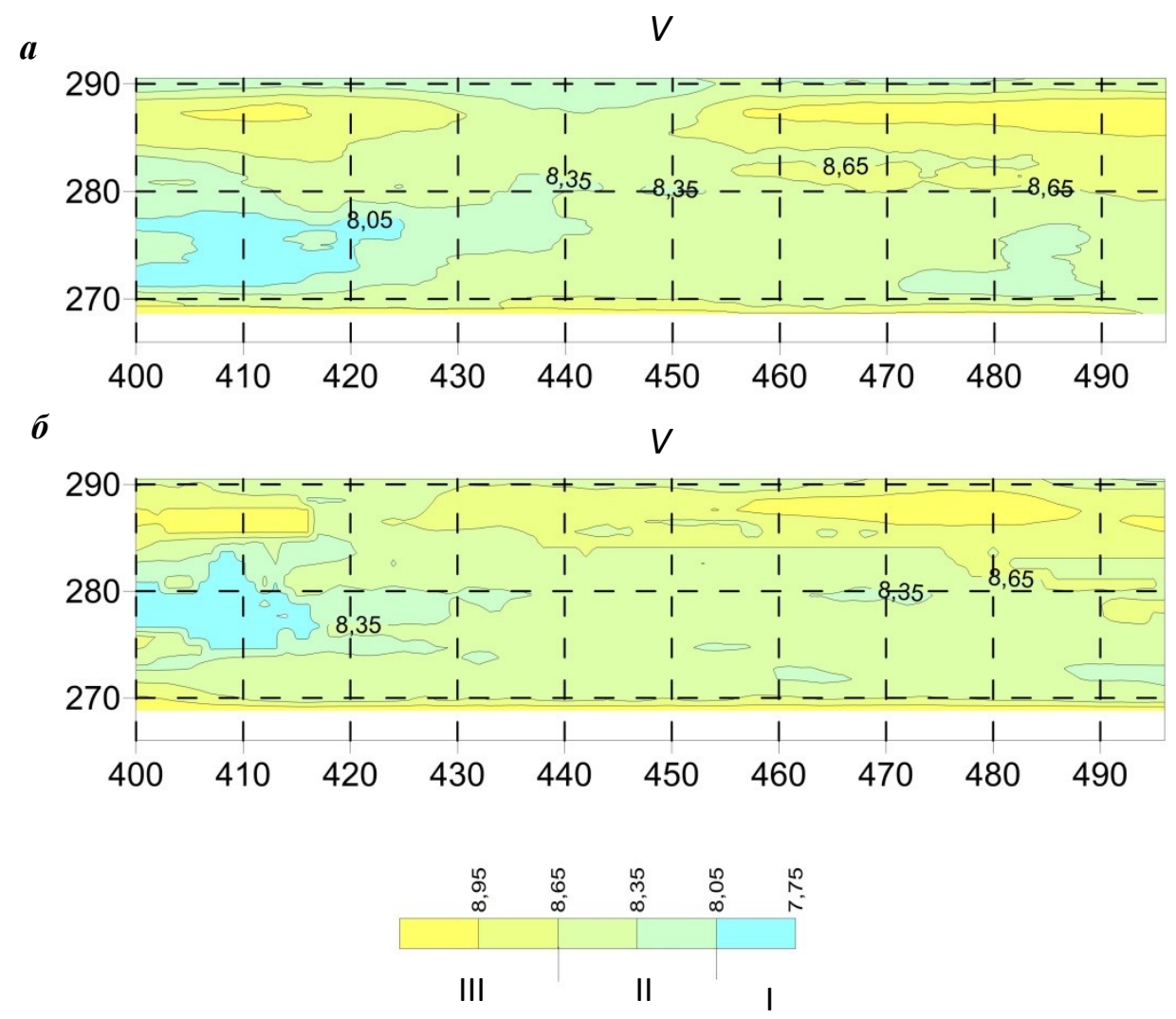

Рис. 4.13. Результаты георадиолокационного зондирования ограждающей дамбы хвостохранилища в октябре (a) и ноябре (б) 2017 г.

Интерпретация анализируемых результатов рис. $4.13, a$, позволяет сделать следующие выводы: приповерхностная зона до отметок 289,5-289 м (глубина $1-1,5$ м), подверженная проникновению осадков, характеризуется начальной невысокой скоростью $V-8,1-8,22$ см/нс с дальнейшим ее нарастанием до 8,36$8,71 \mathrm{~cm} /$ нс на отметках 282,5-280 м (на глубине 8-10 м), что обусловлено, предположительно, ростом плотности и снижением влажности грунтов. В интервале высотных отметок 280-270 м фиксируется зона резкого падения величин скоростей $V$ до значений 7,35-7,71 cм/нс, что может свидетельствовать о значительном намокании грунтов.

Комплексирование электромагнитного и сейсмического обследований позволило установить показатели скорости электромагнитных волн для категорирования грунтов по их свойствам и водонасыщенности [96, 97]:

I - водонасыщенные грунты (менее $8,05 \mathrm{~cm} / \mathrm{Hc}$ );

II — грунты увлажненные, плотные $(8,05-8,65$ см/нс);

III - грунты плотные, естественной влажности (более 8,65 cм/нс). 
Сопоставительный анализ данных, полученных в результате георадарного исследования в октябре (рис. 4.13,a) и ноябре (рис. 4.13, б) 2017 г., позволяет сделать два вывода. Во-первых, сравнение двух радарограмм, сделанных в разные периоды для одного и того же участка, показывает хорошую сходимость между результатами обследования. Показатели скорости электромагнитной волны существенно не изменились на протяжении большей части профиля. Во-вторых, как видно из рис. 4.13, б, зона водонасыщения в левой части профиля спустя месяц начала уменьшаться. Также в ноябре 2017 г. наблюдалось незначительное возрастание скорости в приповерхностной зоне, связанное с наступлением отрицательных температур, что, в свою очередь, повлияло на изменение диэлектрической проницаемости разреза, а именно ее уменьшения; свободная вода в порах начала замерзать и превращаться в лед.

Таким образом, проведенные комплексные визуальные и георадарные исследования дамбы позволили идентифицировать и локализовать зоны повышенной фильтрации. Также комплексные, периодичные, визуальные и георадарные обследования насыпных гидротехнических сооружений могут эффективно применяться для мониторинга данных сооружений, направленного на идентификацию локальных нарушений фильтрационной устойчивости и наблюдения за динамикой развития фильтрационных и других процессов как на поверхности, так и в теле сооружения.

По данным визуальных наблюдений были выявлены зоны выхода фильтрующихся вод на поверхность дамбы, а также локальные деформации поверхности дамбы, вызванные локальными нарушениями фильтрационных свойств сооружения. Георадарное обследование вышележащей полки гидротехнического сооружения на данном участке позволило выделить на изучаемом участке зону повышенного водонасыщения и фильтрации. Контрольные измерения данного участка через месяц привели к выводу о воспроизводимости данных георадиолокации во времени и дальнейшей возможности мониторинга изменения фильтрационных процессов во времени. Таким образом, можно сделать обоснованное предположение о том, что комплексное использование визуального обследования и георадиолокации с цифровой обработкой данных может эффективно использоваться для мониторинга насыпных гидротехнических сооружений.

\section{4. Комплексирование георадарного и сейсмического зондирования насыпного сооружения}

Выявление водонасыщенных зон в ограждающих грунтовых гидротехнических сооружениях - актуальная научно-практическая задача, решение которой связано с обеспечением их механической устойчивости и противофильтрационной функциональности. Имеющиеся на сооружениях сети пьезометрических скважин в большинстве случаев не обеспечивают для этих целей необходимого объема данных, что не позволяет решать задачи информационного обеспечения в непрерывном режиме по всему объему сооружения. Вместе с тем в ряде работ показано, что использование геофизических методов мониторинга позволяет получать оперативную информацию о структурных особенностях сооружения и степени водонасыщенности слагающих их грунтов $[39,67,83,84,98,99]$. При этом делаются выводы о том, 
что комплексирование методов, использующих разную природу геофизических полей, позволяет существенно повысить достоверность полевых определений.

В российской литературе в явном виде нет данных о синхронном зондировании грунтового гидротехнического сооружения электромагнитным и сейсмическим методами. В разделе рассмотрено синхронизированное зондирование ограждающей дамбы хвостохранилища АО «Ковдорский ГОК» различными по природе волновыми электромагнитным и сейсмическим методами для уточнения внутренней структуры дамбы и локализации зон различного водонасыщения грунтов. Идея исследования заключалась в том, что, наряду с задачей повышения достоверности определений, здесь будет решаться задача обеспечения технологичности полевых измерений, прежде всего электромагнитным зондированием [93]. Поэтому проведенная серия натурных экспериментов на наблюдательном полигоне ограждающей дамбы хвостохранилища АО «Ковдорский ГОК» по синхронному электромагнитному и сейсмическому зондированию слагающих грунтов позволила не только оценить состояние дамбы, но и создать методическую основу для обеспечения технологичности таких полевых измерений и получения более достоверных и детализированных данных.

Основным параметром для определения и интерпретации структуры и состояния грунтового гидротехнического сооружения электромагнитным и сейсмическим зондированием, как известно, является скорость распространения соответствующих волн.

Как уже упоминалось ранее, распространение электромагнитных волн в геологической среде-диэлектрике описывается уравнениями Максвелла, скорость распространения электромагнитных волн $V$ в среде напрямую связана c действительной частью комплексной относительной диэлектрической проницаемости среды. Диэлектрическая проницаемость грунтов напрямую связана с их влажностью, на сегодняшний день получен ряд эмпирических выражений (3.1-3.2), определяющих эту связь.

Из приведенных эмпирических выражений следует, что повышение влажности грунтов приводит к увеличению значений диэлектрической проницаемости. Таким образом, при электромагнитном зондировании признаком роста влагонасыщения грунтов является увеличение определяемых значений $\varepsilon$, что, в свою очередь, отражается в падении скорости электромагнитной волны. Вместе с тем вследствие сложности получения распределенных скоростных данных электромагнитного зондирования их интерпретация в подавляющем большинстве случаев производится также на основе детального анализа амплитудных, частотных и фазовых характеристик электромагнитного сигнала, сопоставления осей синфазности, которые в совокупности отличаются друг от друга характером картины, поверхностями угловых несогласий, интенсивностью отражающих горизонтов. Поэтому задача повышения технологичности и достоверности данных электромагнитного зондирования в части уточнения структуры и определении границ зон водонасыщения является актуальной. Для ее решения были использованы в том числе и возможности сейсмических методов зондирования.

Распространение сейсмической волны в геологической среде представляет собой поле смещений частиц среды. В идеально упругой 
однородной изотропной среде оно описывается уравнением динамического равновесия Ламе [73, 100]:

$$
\frac{\lambda+2 G}{\rho} \operatorname{graddiv} \vec{u}+\frac{G}{\rho} \operatorname{rotrot} \vec{u}=\frac{d^{2} \vec{u}}{d t^{2}},
$$

где $u=u\{x, y, z, t)$ - вектор смещения частиц среды под действием проходящей волны в пространстве $x, y, z$, и во времени $t ; \rho-$ плотность среды; $\lambda, G$ - упругие модули.

Через плотность среды $\rho$ и упругие модули $\lambda$ и $G$ в формуле (4.2) представлены скорости продольных $V_{p}$ и поперечных волн $V_{s}$ в среде $[73,101]$ :

$$
V_{p}=\sqrt{\frac{\lambda+2 G}{\rho}} ; V_{s}=\sqrt{\frac{G}{\rho}} .
$$

В сейсмике в качестве показателя для идентификации водонасыщенных зон в грунтах используется отношение скоростей $V_{s} / V_{p}$, функционально определяющее коэффициент Пуассона среды $\mu$, согласно выражению [73]:

$$
\mu=\frac{0,5-\left(V_{s} / V_{p}\right)^{2}}{1-\left(V_{s} / V_{p}\right)^{2}} .
$$

На основе многочисленных натурных и лабораторных определений, выполненных для различных грунтов плотин и дамб ЗЧРСА в увлажненном состоянии, значения отношения $V_{s} / V_{p}$ могут варьировать в пределах $0,31-0,37$ $[102,103]$. Посредством замеров скоростей $V_{p}$ и $V_{s}$ в этом блоке были выделены различные по водонасыщению зоны, что позволило определять границы увлажнения с большей надежностью. На рис. 4.14 эти зоны показаны на графике функциональной связи выражения (4.4).

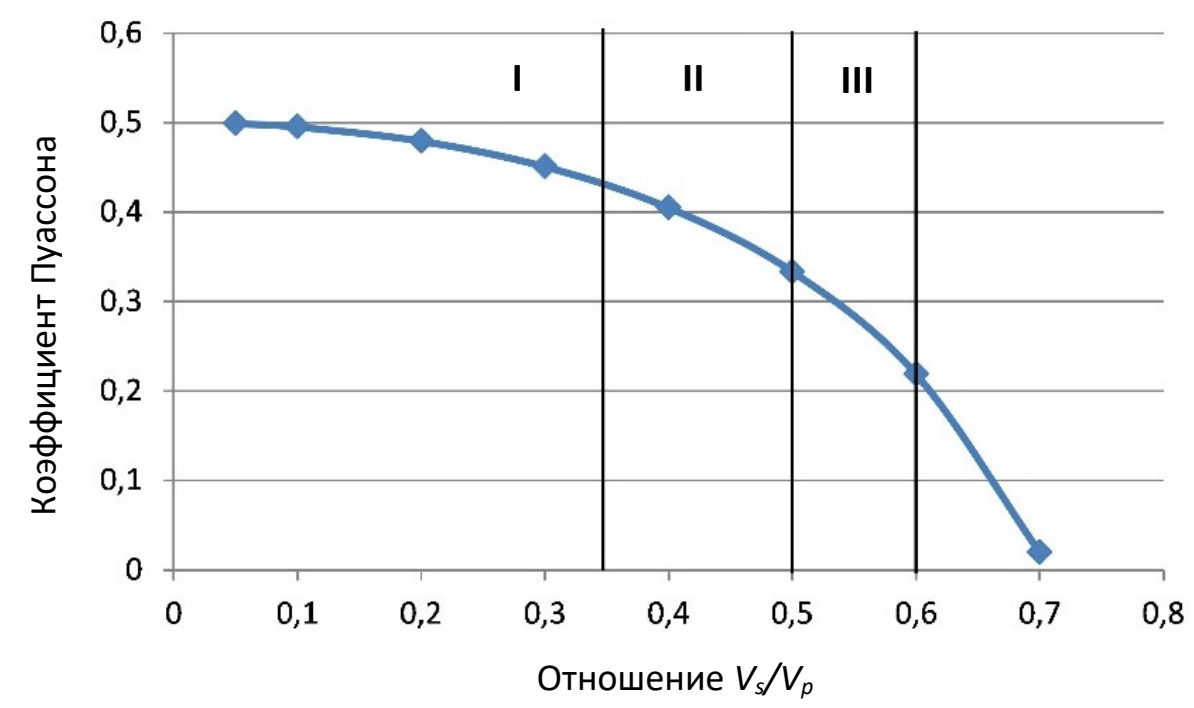

Рис. 4.14. Оценка увлажнения грунтов по отношению скоростей упругих волн $V_{s} / V_{p}$ : I — водонасыщенные грунты; II — грунты увлажненные, плотные; III — грунты плотные, естественной влажности 
Результаты выполненных синхронных измерений электромагнитным и сейсмическим методами на ограждающей дамбе хвостохранилища Ковдорского ГОКа представлены на рис. 4.15 в виде картин отношения сейсмических скоростей $V_{s} / V_{p}(a)$ и скорости электромагнитной волны $V(\sigma)$. Сопоставляя палитры выделенных на картинах (рис. 4.15, a, б) зон по вышеуказанным критериям, отражающие структурные особенности и различную водонасыщенность грунтов обследуемого участка, визуально можем отметить их подобие в местоположении и размерах на исследуемых разрезах. Для более конкретного сопоставления результатов на рис. 4.16 представлены графики изменчивости контролируемых показателей в отдельных разрезах на четырех пикетах, которые детально подтверждают их идентичность.

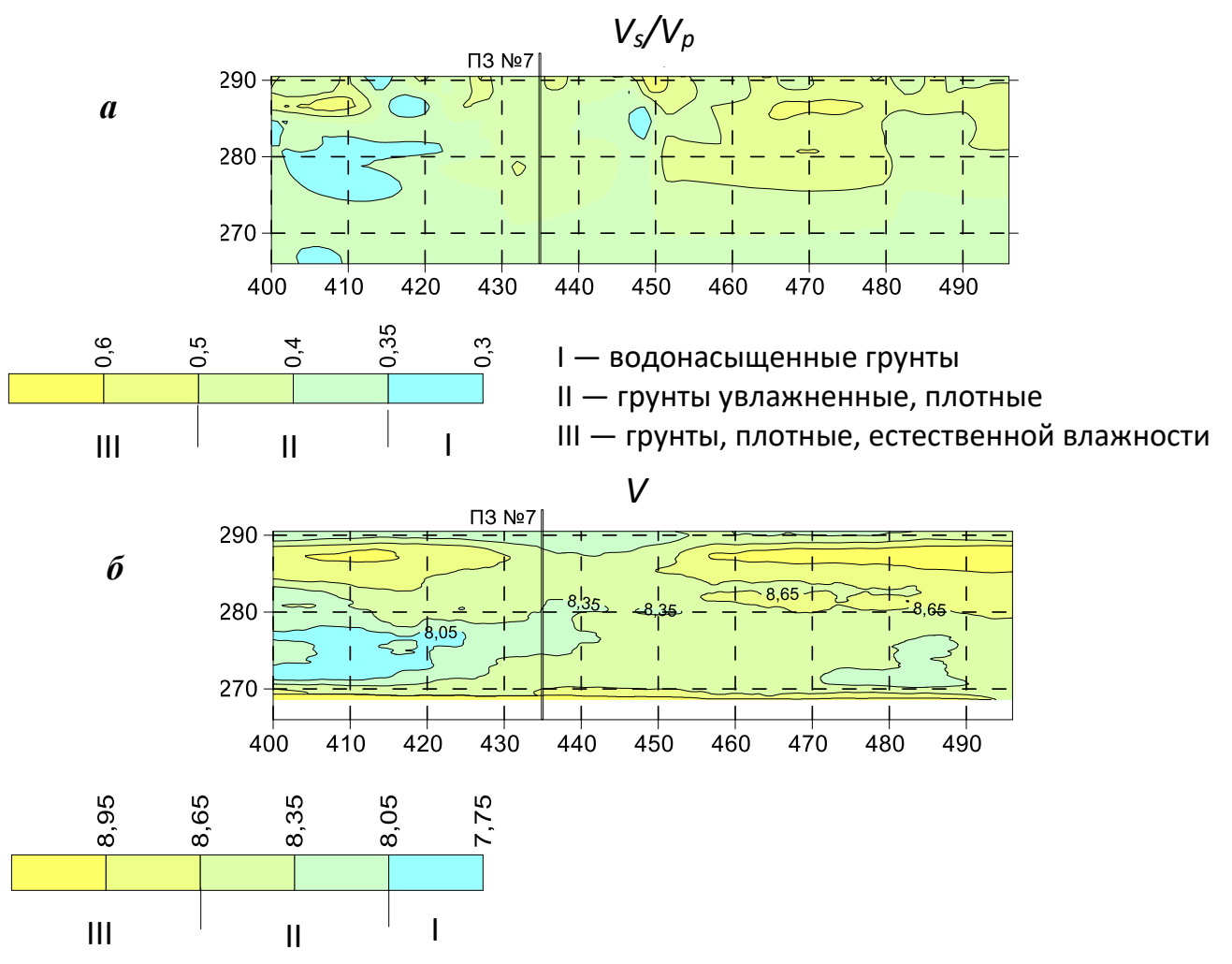

Рис. 4.15. Результаты синхронного сейсмического (a) и электромагнитного (б) зондирования дамбы

Интерпретация анализируемых результатов выполненных синхронных исследований ограждающей дамбы в целом позволяет сделать следующие выводы. Приповерхностная зона грунтов дамбы (см. рис. 4.15, б) до отметки 289,5-289 м (1-1,5 м), подверженная проникновению осадков, характеризуется начальной невысокой скоростью электромагнитной волны $V-8,1-8,22 \mathrm{~cm} / \mathrm{Hc}$, с дальнейшим относительно резким ее нарастанием до 8,36-8,71 cм/нс на отметке 282,5-280 м (8-10 м), что обусловлено, скорее всего, ростом плотности и снижением влажности грунтов. В интервале высотных отметок 280-270 м 
фиксируется зона резкого падения скорости $V$ до значений 7,35-7,71 см/нс. Изменения показателя $V_{s} / V_{p}$ при сейсмическом зондировании, составляющего на этих же отметках $0,30-0,35$ (голубая палитра рис. $4.15, a$ ), однозначно свидетельствуют, что грунты здесь подвержены значительному намоканию и по степени водонасыщения могут быть отнесены к категории I (см. рис. 4.14).

Таким образом, сопоставительный анализ данных электромагнитного и сейсмического зондирования показал наличие уверенной корреляции (сходимости) полученных результатов. Статистически корреляционная взаимосвязь массивов данных $V$ и $V_{s} / V_{p}$ определена с шагом $x=0,25 \mathrm{м}, y=0,1 \mathrm{м}$, где на каждый интервал глубин приходится 7700 точек сравнения. Вычисленный коэффициент корреляции варьирует от 0,56 до 0,68 в интервале высотных отметок 290,5-280 м и от 0,68 до 0,83 в интервале $280-272$ м, что соответствует средней и сильной связи данных по общей классификации коэффициента корреляции [104]. Следует отметить, что для интервала отметок 276-278 м выявлена наибольшая корреляционная взаимосвязь данных с коэффициентом 0,83 .

По данным статистического облака точек построен график эмпирической зависимости скорости электромагнитной волны $V$ от отношения скоростей упругих волн $V_{s} / V_{p}$ (рис. 4.17).

Установлена следующая взаимосвязь полученных данных с величиной достоверности аппроксимации 0,6915 :

$$
V=2,78 \frac{V_{s}}{V_{p}}+7,09 .
$$

Выполненные исследования синхронного электромагнитного и сейсмического зондирования предоставляют основу для категорирования грунтов по их свойствам и водонасыщенности в разрезах дамбы согласно приведенной ниже табл. 4.3.

\section{Таблица 4.3}

Категорирование грунтов по водонасыщению на основе натурных сейсмических и электромагнитных зондирований

\begin{tabular}{|l|c|c|c|}
\hline \multicolumn{1}{|c|}{ Категория водонасыщенности грунта } & I & II & III \\
\hline $\begin{array}{l}\text { По данным сейсмического } \\
\text { зондирования, } V_{s} / V_{p}\end{array}$ & $0,3-0,35$ & $0,36-0,5$ & $0,51-0,6$ \\
\hline $\begin{array}{l}\text { По данным электромагнитного } \\
\text { зондирования, } V\end{array}$ & $<8,05$ & $8,06-8,66$ & $8,67>$ \\
\hline
\end{tabular}

Полученные результаты также позволили, по аналогии с сейсмикой, установить эмпирическую корреляционную связь скорости электромагнитной волны $V$ с такой важной характеристикой грунтов, как коэффициент Пуассона $\mu$. Вид этой связи отражен в выражении

$$
\mu=\frac{0,5-(0,36 V-2,55)^{2}}{1-(0,36 V-2,55)^{2}} .
$$




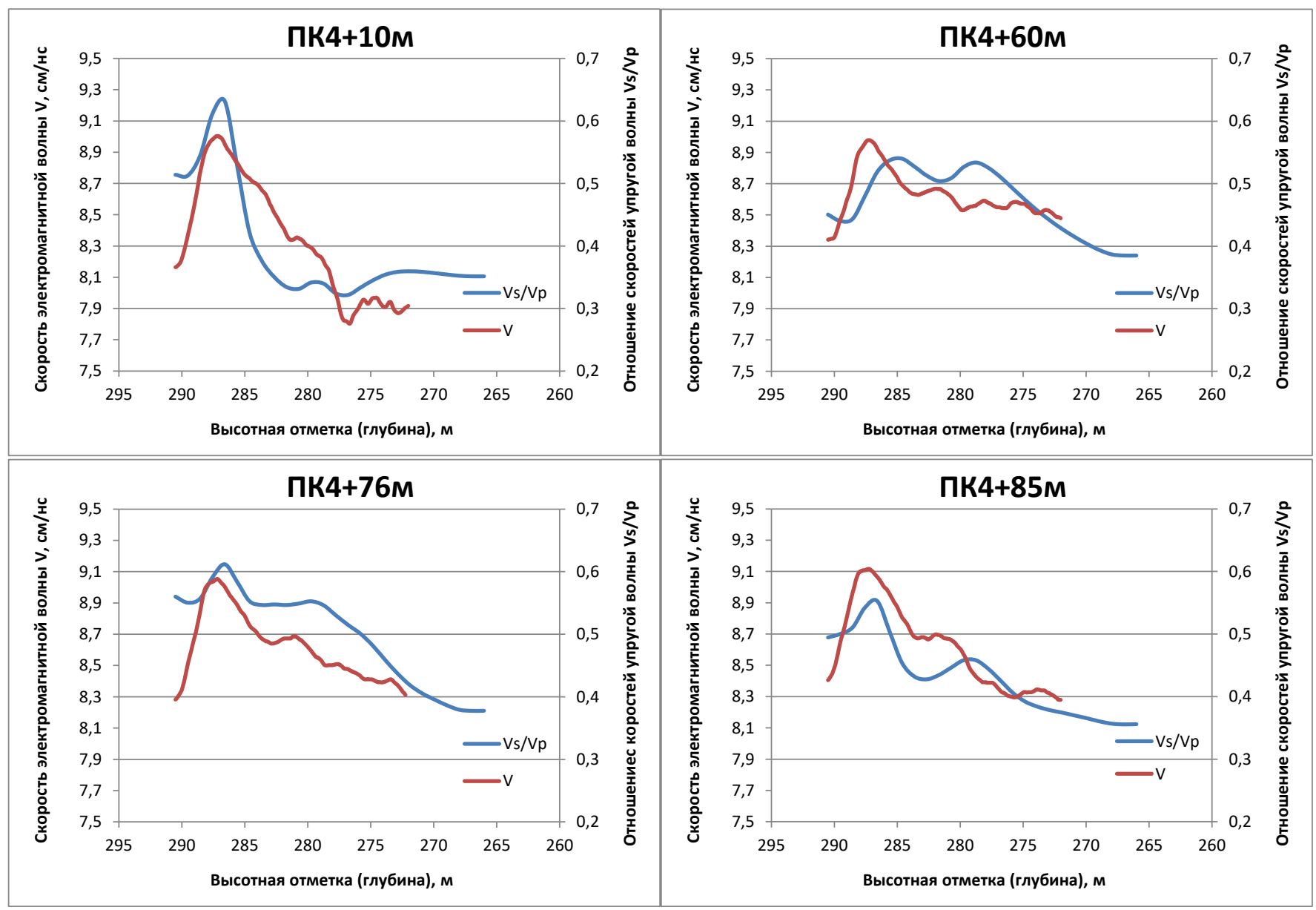

Рис. 4.16. Сопоставление результатов электромагнитного $(V)$ и сейсмического $\left(V_{s} / V_{p}\right)$ зондирования в сечениях дамбы 


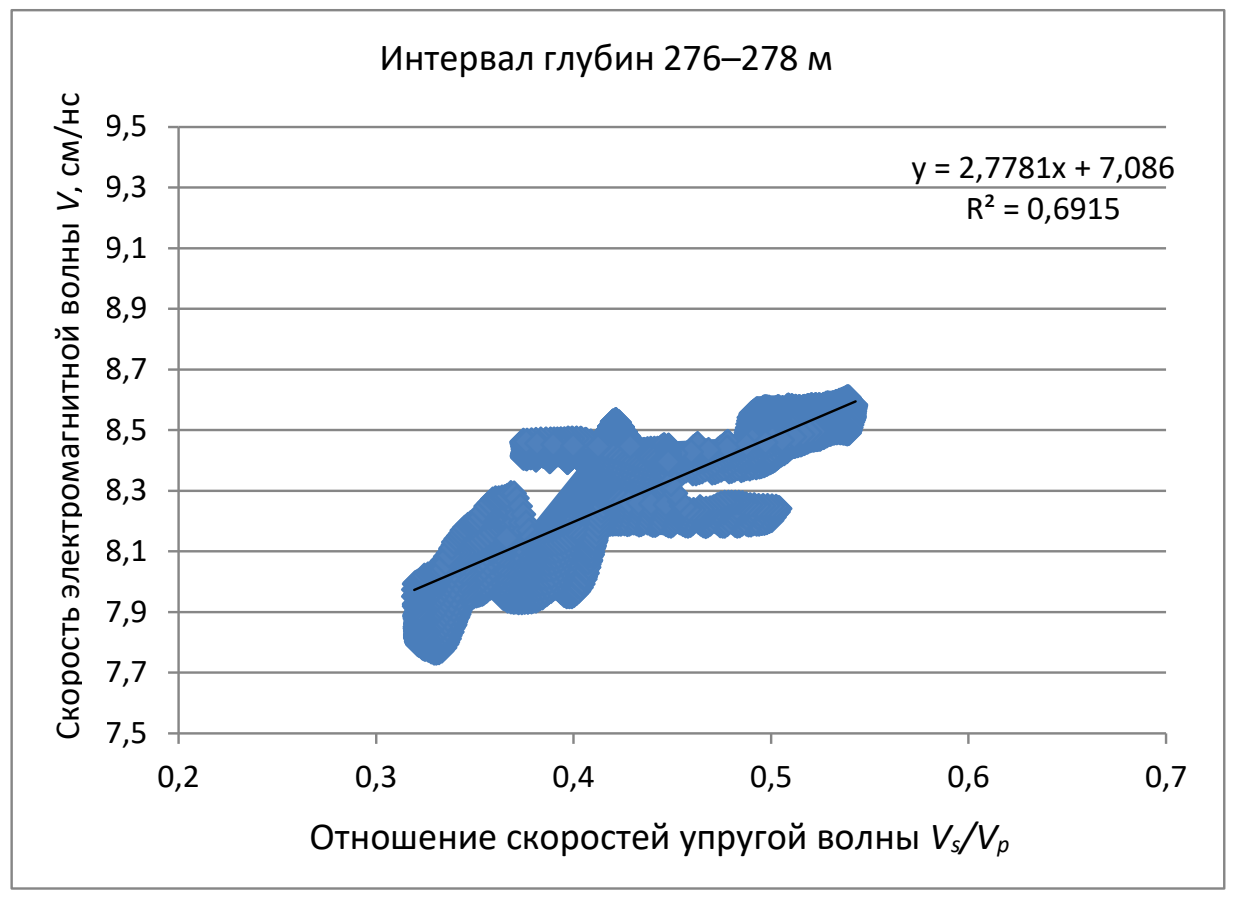

Рис. 4.17. Статистическая взаимосвязь скорости электромагнитной волны $V$ и отношения скоростей упругих волн $V_{s} / V_{p}$ на интервале отметок 276-278 м дамбы

Проведение синхронного электромагнитного и сейсмического зондирования ограждающей дамбы хвостохранилища Ковдорского ГОКа позволило более детально и надежно уточнить внутреннюю структуру и степень водонасыщенности ее грунтов. Определены диапазоны скорости электромагнитной волны и интервалы значений отношения скоростей продольной и поперечной упругой волны при переходе из сухих, плотных грунтов дамбы в увлажненные и далее в водонасыщенные. Сопоставительный визуальный, графический и статистический анализ показал хорошую корреляционную взаимосвязь полученных электромагнитных и сейсмических данных, что позволило, по аналогии с сейсмикой, установить эмпирическую корреляционную связь скорости электромагнитной волны $V$ и коэффициента Пуассона $\mu$.

В целом, выполненные исследования грунтового гидротехнического сооружения посредством синхронного электромагнитного и сейсмического зондирования предоставляют основу для категорирования грунтов по их водонасыщенности в разрезах сооружения. Синхронизация методов дала дополнительное обоснование для достоверной интерпретации данных электромагнитного зондирования при решении задач локализации водонасыщенных участков в теле грунтовых сооружений с большей надежностью и технологичностью.

\section{5. Роль синхронности при комплексировании волновых исследований}

В настоящее время основной тенденцией геофизики при исследовании горно-геологических структур является повышение информативности 
и надежности получаемых данных. Существование большого количества методов геофизики свидетельствует об отсутствии какого-то одного стандартного геофизического метода, способного обеспечить оперативное и качественное получение требуемой информации о горно-геологической среде, ввиду сложности и неоднозначности получаемых данных. Следовательно, рациональный выбор и комплексирование геофизических методов позволяет повысить уровень и надежность данных при решении различных задач. В свою очередь, оценка изменений состояния горно-геологических структур, обусловленных как техногенными, так и природными факторами, накладывает более жесткие требования на комплексирование методов, включая синхронность измерений для получения единых данных, отражающих структуру. Поэтому в данном разделе основное внимание было уделено особенностям синхронизации геофизических исследований при их комплексировании.

Система ограждающих дамб и хвостохранилище представляют собой ответственное гидротехническое сооружение, эксплуатация которого должна выполняться в строгом соответствии с требованиями промышленной безопасности. Нарушение устойчивости и функциональности ограждающих дамб может привести к аварийной ситуации и значительному социальноэкономическому ущербу. Так, в 2013 и 2017 гг. произошли интенсивные протечки и размывы нижнего склона ограждающей дамбы хвостохранилища АО «Ковдорский ГОК», приведшие к необходимости дополнительных исследований гидротехнического сооружения [67, 83, 84, 93, 96].

В 2013 и 2017 гг. на наблюдательном полигоне дамбы хвостохранилища АО «Ковдорский ГОК» в целях уточнения границ вариаций контрольных геофизических показателей при локализации зон водонасыщения и намокания грунтов выполнен цикл наблюдений сейсмическим и георадарным методами, где в качестве показателей результатов приняты: $V_{s} / V_{p}$ - для сейсмического метода; $V$ - скорость прохождения электромагнитной волны для георадарного метода наблюдений. Основные результаты выполненных синхронных исследований представлены в виде радарограммы скорости электромагнитной волны $V$ (рис. $4.18, a$ ) и сейсмотомограммы соотношения сейсмических скоростей $V_{s} / V_{p}$ (рис. $4.18,6$ ). На палитрах, выделенных по вышеуказанным показателям зон, визуально отмечается подобие в распределениях исследуемых разрезов, что отражает структурные особенности обследуемого участка. Для количественного сопоставления результатов построены графики изменчивости контролируемых показателей по трассам зондирования в отдельных разрезах на двух пикетах (рис. 4.19).

Интерпретация анализируемых результатов 2017 г. позволяет сделать следующие выводы. Приповерхностная зона до 289,5-289 м (1-1,5 м), подверженная проникновению осадков, характеризуется начальной невысокой скоростью $V-$ $8,1-8,22 \mathrm{~cm} / \mathrm{нc}$, с дальнейшим резким ее нарастанием до 8,36-8,71 см/нс на глубине 282,5-280 м (8-10 м), что обусловлено, скорее всего, ростом плотности и снижением влажности грунтов. В интервале высотных отметок 280-270 м фиксируется зона резкого падения величин скоростей до значений 7,35-7,71 см/нс. Глядя на подобные изменения показателя $V_{s} / V_{p}$ на этих же отметках, составляющего $0,30-0,35$ по сейсмотомограмме (рис. $4.18, \sigma$ - голубая палитра), можем заключить, что грунты здесь подвержены значительному намоканию. 


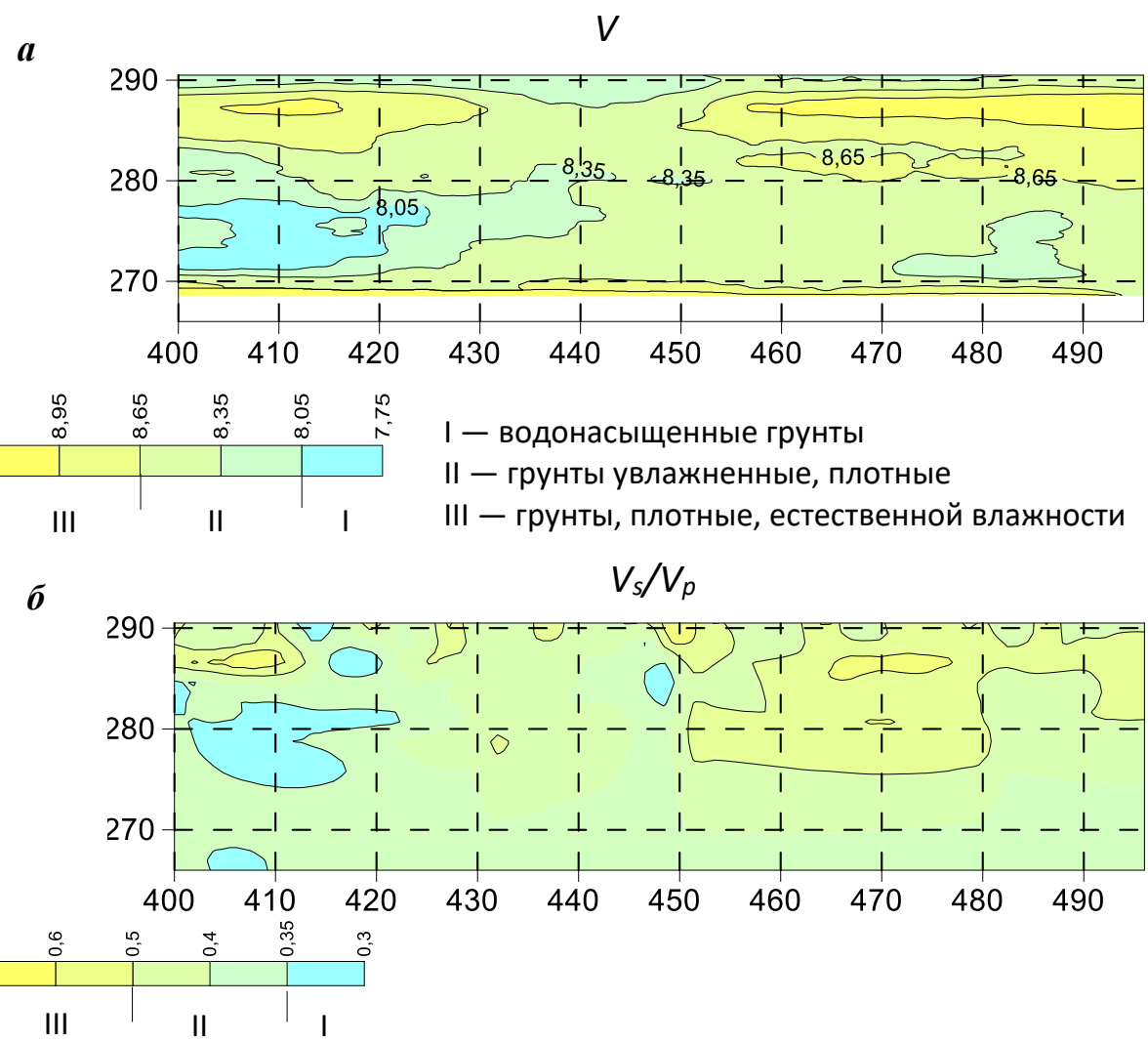

Рис. 4.18. Результаты синхронного георадарного (a) и сейсмического (б) зондирования дамбы 2017 г.

Интерпретация результатов наблюдений 2013 г. (рис. 4.20) позволяет сделать следующие выводы. Анализ палитры выделенных зон по вышеуказанным критериям показал визуальное несоответствие в распределениях скоростей исследуемых разрезов, отражающих структурные особенности обследуемого участка. По данным георадиолокации, приповерхностная зона на глубину до 2 м представлена увлажненными грунтами на двух интервалах - 400-430 и 470-480 м, в свою очередь, по данным сейсмического метода, приповерхностная зона увлажнена только очень небольшими локальными участками до 5 м шириной и только в конце профиля 470 м совпадает с данными георадиолокации. По данным сейсмического метода, водонасыщенные грунты выделяются в самом конце профиля на интервале 485-498 м на всю глубину разреза, а по данным георадиолокации, водонасыщенные грунты определяются по всей длине профиля на абсолютной отметке 270-275 м. Такие изменения можно объяснить не единовременным комплексированием методов (разница во времени измерений составила несколько дней), но и влиянием природных (обильные осадки) и техногенных факторов (сброс воды с фабрики), которые также нельзя исключать. Однако в центральной части профиля показатели имеют очень хорошую повторяемость: здесь повсеместно плотные грунты естественной влажности. Для более конкретного сопоставления результатов представлены графики (рис. 4.21) изменчивости контролируемых показателей в отдельных разрезах на двух пикетах. 

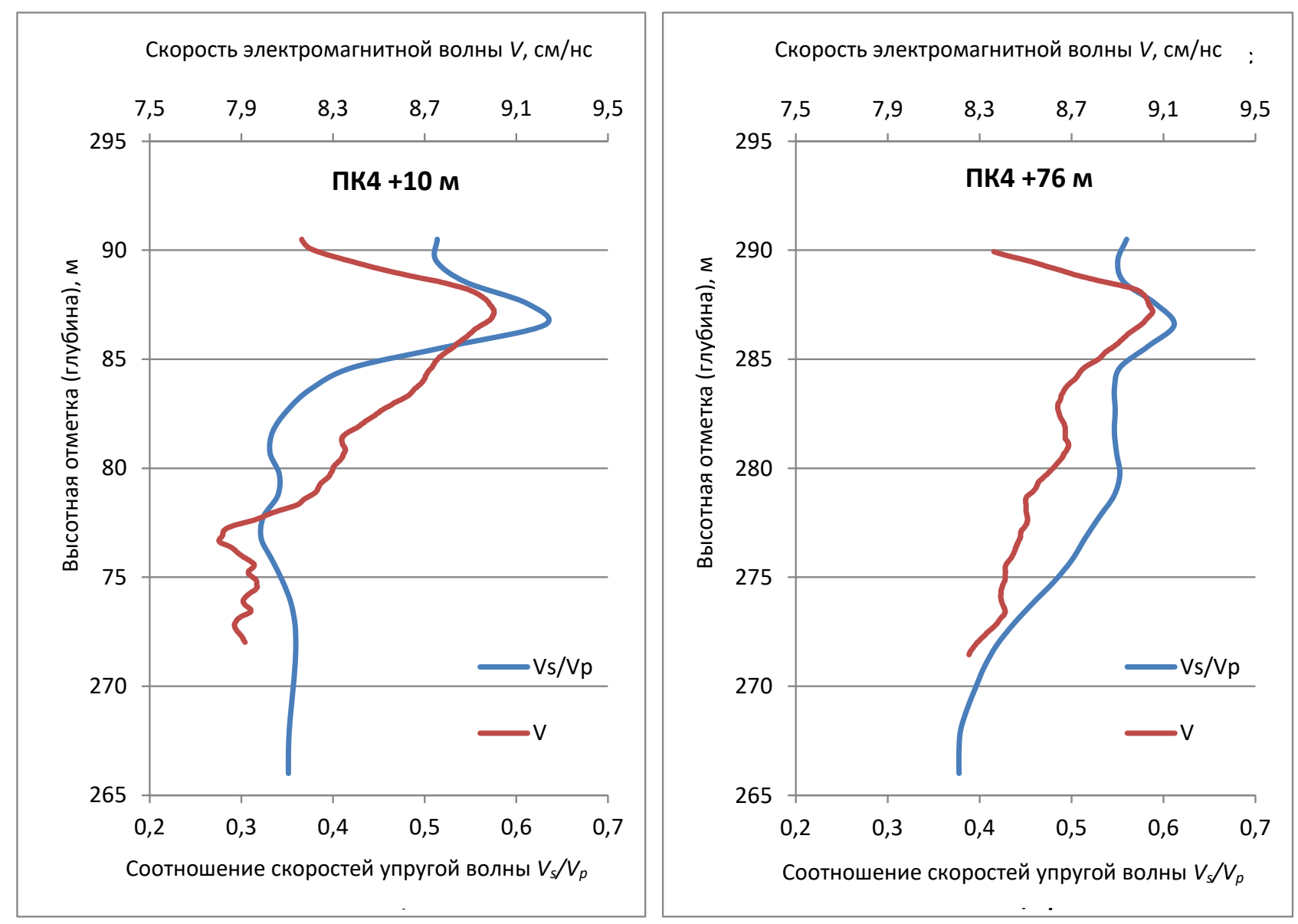

Рис. 4. 19. Сопоставление результатов наблюдений 2017 г. георадарным $(V)$ и сейсмическим $\left(V_{s} / V_{p}\right)$ зондированием по трассам 


\section{V}

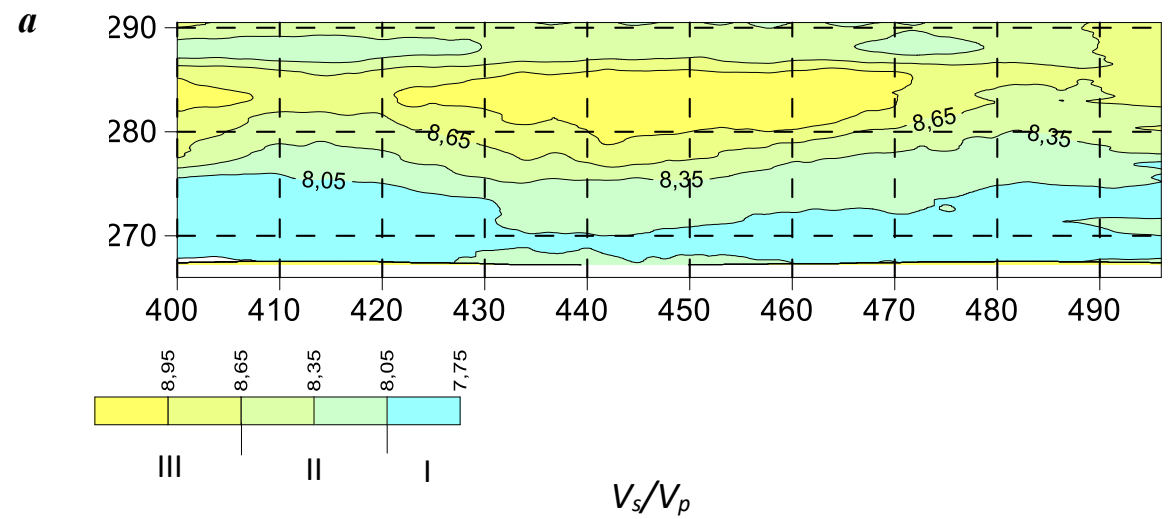

б

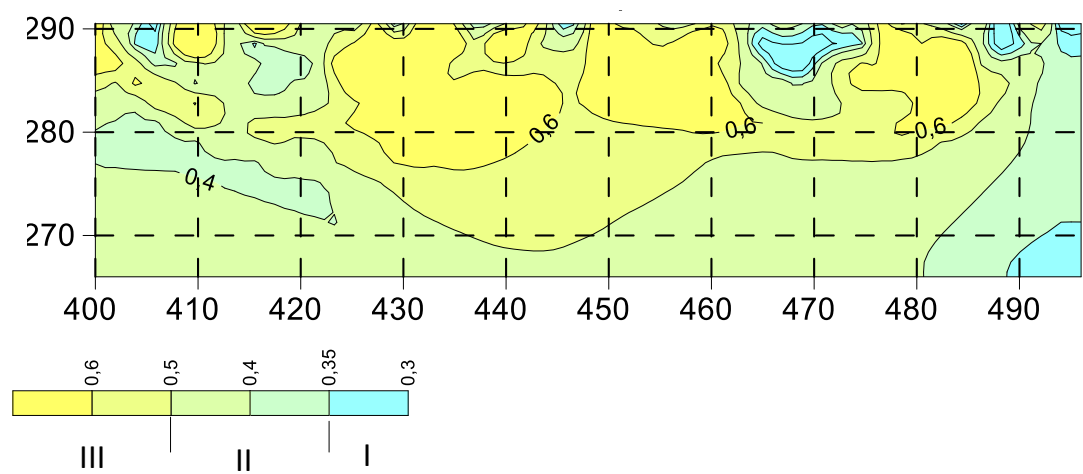

Рис. 4.20. Результаты зондирования дамбы 2013 г. георадарным (a) и сейсмическим (б) методами

Сравнение данных георадарного и сейсмического зондирования показало наличие уверенной корреляции (сходимости) полученных результатов, однако данные 2017 г. имеют более тесную связь (рис. 4.22), что связано с комплексированием указанных методов в пространственно-временной увязке.

Выполнены комплексные геофизические исследования для целей оценки состояния ограждающей дамбы АО «Ковдорский ГОК». Проведенные работы позволили оценить состояние дамбы и выявить локальные зоны повышенного водонасыщения и фильтрации. Установлено, что слагающие дамбу грунты находятся во влажном и водонасыщенном состоянии. Определена зональная фильтрационная неоднородность слагающих дамбу грунтов, уточнена структура ограждающей дамбы и подстилающего основания.

На основе вычисленного коэффициента корреляции значений скоростей электромагнитной и сейсмической волны выявлено, что синхронизация геофизических исследований позволяет существенно повысить достоверность полевых определений и получить более надежные данные.

Результаты выполненных исследований подтвердили информативность георадарных определений для выявления наиболее уязвимых участков насыпного грунтового гидротехнического сооружения, а также для обнаружения локализации водонасыщенных зон в грунтах с высокой достоверностью и технологичностью. 

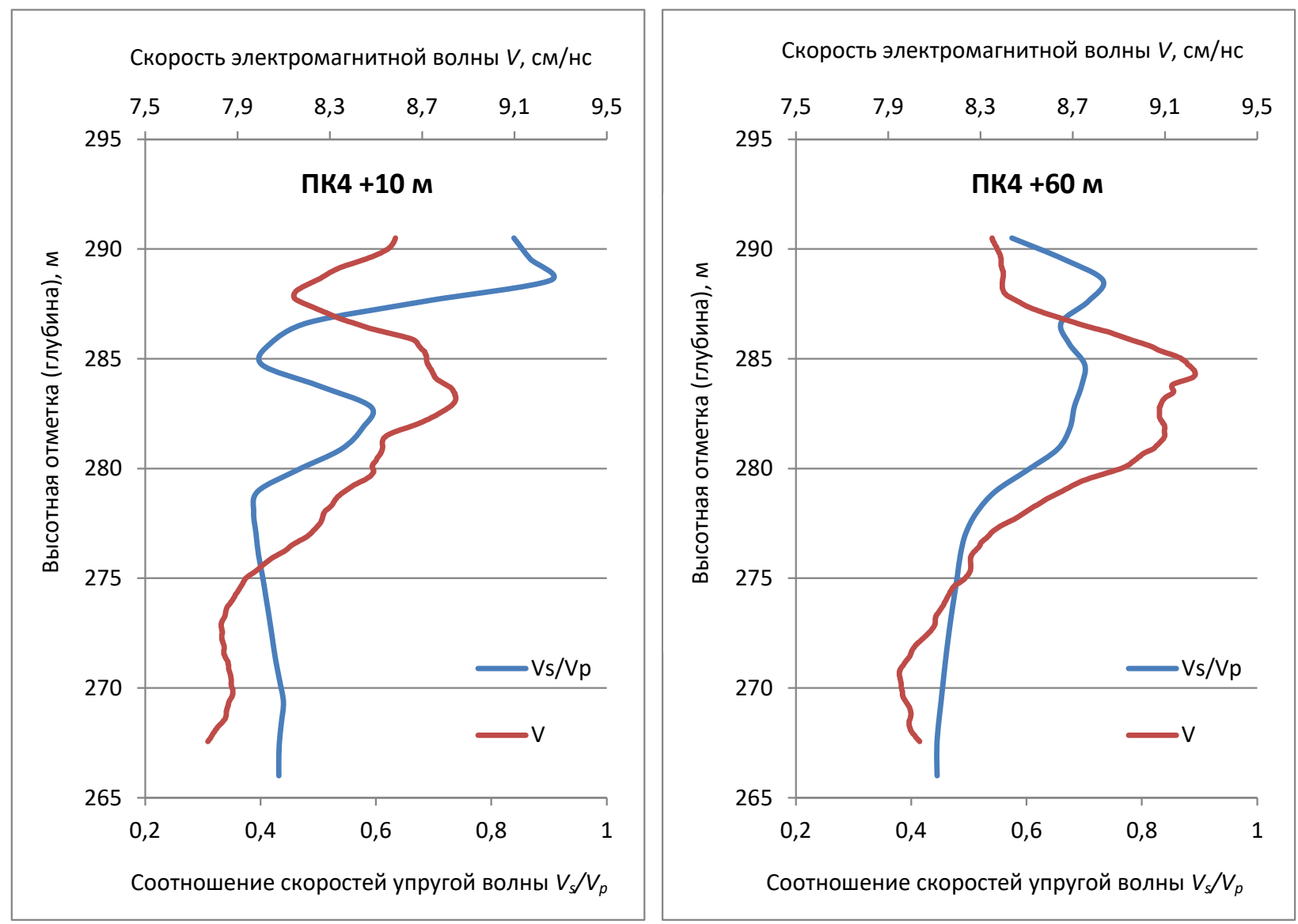

Рис. 4.21. Сопоставление результатов наблюдений 2013 г. георадарным $(V)$ и сейсмическим $\left(V_{s} / V_{p}\right)$ зондированием по трассам

в сечениях дамбь 


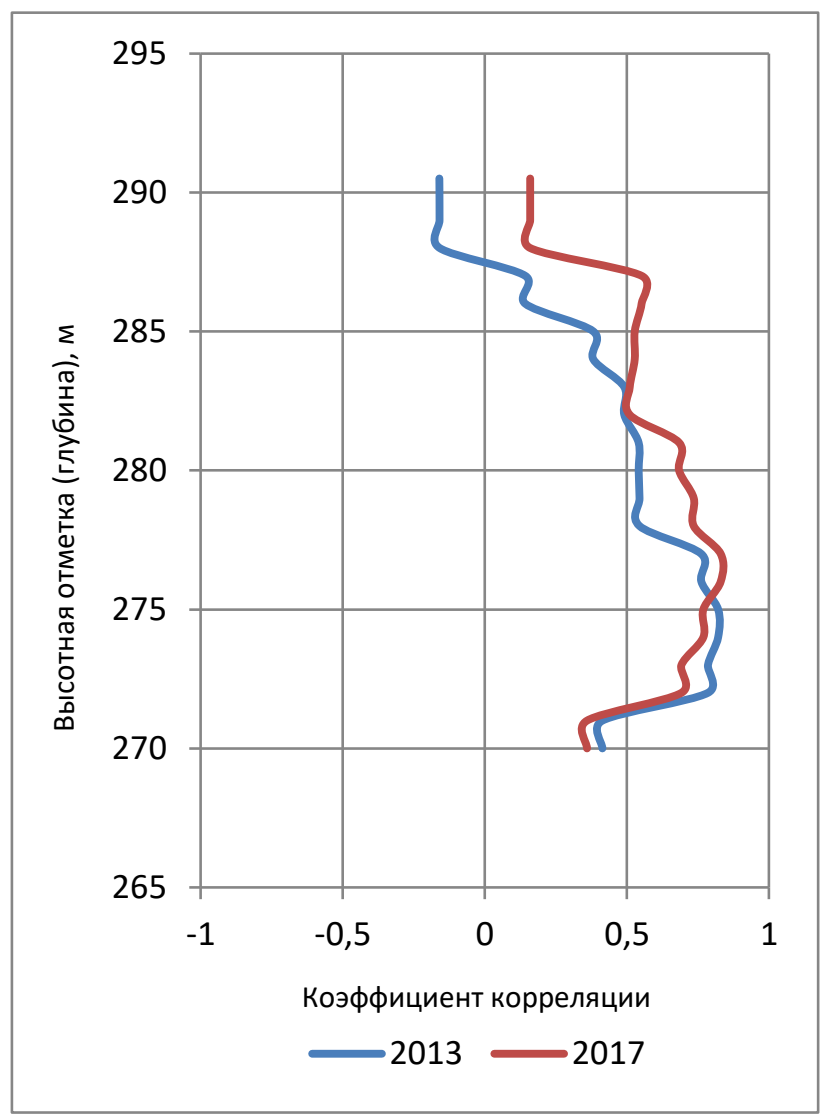

Рис. 4.22. Коэффициент корреляции связи скоростей электромагнитных волн $V$ и соотношения скоростей упругой волны $V_{s} / V_{p}$ 


\section{ЗАКЛЮЧЕНИЕ}

Исследование структуры и состояния горнотехнических объектов попрежнему остается одной из актуальных проблем в задачах обеспечения их безопасной функциональности. Применение георадарного зондирования при достаточной методической и технологической проработке позволяет найти достоверные решения этой проблемы. Вопросам методических подходов, применяемому оборудованию и теоретическому обоснованию интерпретации результатов георадарного зондирования и посвящена настоящая монография.

Более чем 10-летний опыт авторов и многочисленное применение георадарного зондирования горнотехнических объектов показали хорошую информативность метода в задачах исследования их структуры и состояния. Георадарные определения были выполнены на всех крупных горнопромышленных предприятиях западной части российского сектора Арктики, включая АО «Арктикуголь» на арх. Шпицберген.

Параметры результирующего электромагнитного сигнала георадарного зондирования информативно отражают внутреннюю изменчивость свойств и неоднородность структуры исследованных объектов. Представительным числом инструментальных измерений выявлено, что наведенное электромагнитное поле искажается на участках различия физических свойств пород и грунтов (зоны неоднородностей массива, участки повышенной трещиноватости, зоны повышенного водонасыщения и т. п.).

Для теоретического обоснования методических подходов к идентификации на радарограммах структурных нарушений скальных пород было применено компьютерное моделирование электромагнитного поля, индуцированного георадарным зондированием. Моделирование позволило существенно снизить неоднозначность в процессе интерпретации георадарных данных посредством понимания механизма формирования особенностей волновых характеристик (оси синфазности, амплитудные значения) и сравнения модельных данных с натурными. Были установлены закономерности формирования волновых картин осей синфазности и амплитудных характеристик сигнала синтетических радарограмм массива скальных пород, ослабленного разнонаклонной структурной неоднородностью, на которых при приближении георадара к неоднородности на радарограмме заблаговременно проявляются отражения в виде «хвостов» гипербол от краевых частей неоднородности. Ключевым параметром здесь является интенсивность искажения волнового поля, которая определяется контрастностью (соотношением) физических свойств пород, пространственной ориентацией и глубиной расположения неоднородности. Таким образом, применение компьютерного моделирования электромагнитного поля, индуцированного георадарным зондированием, позволило создать теоретические методические основы идентификации горизонтальных, наклонных и вертикальных структурных нарушений в скальном массиве по волновым данным радарограмм посредством анализа осей синфазности сигналов.

На основе результатов выполненных исследований предложены геофизические признаки идентификации зон повышенной нарушенности скальных пород, заключающиеся в количественной оценке изменения амплитудной характеристики отраженного электромагнитного сигнала, диэлектрической проницаемости пород и атрибута $Q$-фактор. Эмпирическая 
взаимосвязь амплитудно-частотных характеристик отраженного/преломленного сигнала, значений диэлектрической проницаемости пород и атрибута $Q$-фактор с нарушенностью скальных пород позволяет оперативно выявлять и оценивать состояние горнотехнического объекта в скальном массиве.

В монографии приведены результаты георадарного исследования только некоторых горнотехнических объектов АО «Ковдорский ГОК» и АО «Апатит» (описание всех выполненных георадарных исследований в западной части российского сектора Арктики является предметом другой работы). Показано, что георадарное зондирование позволяет определить как геологическое строение и нарушенность скального породного массива до проведения буровзрывных работ, так и степень дезинтеграции пород после взрывной отбойки. Методический подход к интерпретации заключался в количественной оценке изменения параметров электрофизических свойств пород, а именно диэлектрической проницаемости и скорости распространения электромагнитной волны, вследствие воздействия на породный массив взрывом.

Одним из методических приемов выполняемых исследований была оценка влияния водонасыщенности трещин и пор скальных пород на результирующие значения георадарного зондирования. Идея заключалась в том, что водонасыщенность является своего рода индикатором, который позволяет более контрастно выявлять зоны повышенной нарушенности пород, в отличие от сухих пород, для которых изменения значений диэлектрической проницаемости в ненарушенном и нарушенном массиве незначительны. Примененный подход дал возможность более контрастно выявить зоны повышенной нарушенности, что позволило повысить точность расчета количества и расположения взрывных скважин, объемов заряжаемой взрывчатки и обеспечило более качественное дробление горной породы с минимизацией выхода негабарита.

Отдельное внимание авторами уделено вопросу о возможной взаимосвязи параметров георадарных исследований и определений напряженного состояния массивов скальных пород, Выявлены некоторые закономерности, подтверждающие возможность применения высокочастотного электромагнитного зондирования как вторичного метода исследования, дополняющего метод разгрузки, для оценки напряженного состояния скальных пород.

Установленные закономерности изменения волновых характеристик регистрируемого сигнала георадарного зондирования снежно-породных конгломератов позволили создать методическую основу для планирования проведения буровзрывных работ в целях необходимого дробления смерзшихся породных отвалов. Тем самым была создана научно-техническая платформа для решения задач перемещения ранее созданных отвалов горных пород за контуры одного из развивающихся карьеров АО «Апатит».

Разработанные методические подходы при решении задачи перемещения отвалов горных пород за контуры развивающегося карьера нашли свое применение при георадарных исследованиях грунтовых насыпных сооружений. Выявленные скачкообразные изменения амплитуд сигналов на волновой картине радарограмм, обусловленные включением снега и льда в раздробленные скальные породы, присущи и водонасыщенным в разной степени насыпным грунтам. Ключевым признаком этих изменений является вариативный характер распределения значений диэлектрической проницаемости. 
Комплексирование георадарного и сейсмического методов позволяет повысить достоверность интерпретации данных электромагнитного зондирования при решении задач локализации водонасыщенных участков в теле насыпных грунтовых сооружений с большей надежностью и технологичностью. Выявленные комплексированием методов диапазоны скорости электромагнитной волны при переходе из сухих плотных грунтов в увлажненные и далее в водонасыщенные позволяют существенно повысить достоверность полевых георадарных определений. Эмпирически установленная корреляция скорости электромагнитной волны $V$ с такими важными характеристиками грунтов, как их плотность и коэффициент Пуассона $\mu$, предоставляет основу для расширения области применения георадарных исследований насыпных грунтовых горнотехнических объектов.

Авторы не претендуют на истину «в последней инстанции», в монографии описаны применяемые ими методические подходы, оборудование и результаты выполненных георадарных исследований ряда горнотехнических объектов западной части российского сектора Арктики. Георадарные исследования горнотехнических объектов выполняются и в других регионах Российской Федерации, и авторы с благодарностью примут дополнения или иную точку зрения на применимость и информативность георадарных исследований структуры и состояния как скальных, так и насыпных грунтовых, горнотехнических объектов. 


\section{ЛИТЕРАТУРА}

1. Омельяненко, A. В. Георадиолокационные исследования многолетнемерзлых пород / А. В. Омельяненко, Л. Л. Федорова ; Рос. акад. наук, Сиб. отд-ние, Ин-т горного дела Севера им. Н. В. Черского. Якутск : Изд-во ЯНЦ СО РАН, 2006. $136 \mathrm{c}$.

2. Дручинин, C. В. Влияние проводимости грунта на форму и амплитуду импульсных сигналов георадиолокатора / С. В. Дручинин, Ю. И. Лещанский, Н. Г. Подшибякин // Проблемы дифракции и распространения волн. Москва : Изд-во МФТИ, 1994. С. 105-112.

3. Нерадовский Л. Г. Методическое руководство по изучению многолетнемерзлых пород методом динамической георадиолокации / Л. Г. Нерадовский. Москва : Изд-во РАН, 2009. 337 с.

4. Мельников, H. H. Инновационные георадарные технологии изучения подповерхностной структуры и состояния природно-технических систем / Н. Н. Мельников, А. И. Калашник // Вестник КНЦ РАН. 2010. № 3. С. 4-8.

5. Денисов, $P$. Р. Обработка георадарных данных в автоматическом режиме / Р. Р. Денисов, В. В. Капустин // Геофизика. 2010. № 4. С. 76-80.

6. Капустин, B. В. Применение атрибутного анализа для решения прикладных задач георадарного профилирования / В. В. Капустин, А. В. Синицын // Геофизика. 2018. № 2. С. 17-23.

7. Kopeikin, $V . V$. Deep Penetration Radar: Hydrogeology and Paleorelief of Underlying Medium / V. V. Kopeikin, P. A. Morozov, I. V. Prokopovich, A. V. Popov // 17th Intern. Conf. on Ground Penetrating Radar - GPR-2018. Rapperswil. Switzerland. June 18-21. 2018. P. 394-398.

8. Кулижников, А. М. Неразрушающие георадарные методы в инженерных изысканиях / А. М. Кулижников, А. А. Белозеров // Геопрофи. 2004. № 5. C. $44-47$.

9. Георадиолокация при комплексных геофизических исследованиях ВЧР Бованенковского НГКМ / Б. В. Бучарский, А. Д. Бессонов, И. П. Соколова [и др.] // Разведка и охрана недр. 2008. № 1. С. 3-4.

10. Daniels, D. J. Ground penetration radar / D. J. Daniels ; Institution of Electrical Engineers. 2nd ed. London, 2004. 734 p.

11. Kumlu, D. Clutter reduction in GPR images using nonnegative matrix factorization / D. Kumlu, I. Erer // J. Electromagn. Waves and App. 2018. Vol. 32, No. 16. P. 2055-2066.

12. Maruddani, B. The Development of Ground Penetrating Radar (GPR) Data Processing / B. Maruddani, E. Sandi // Intern. J. Machine Learning and Computing. 2019. Vol. 9, No. 6. December. P. 768-773.

13. Александров, П. Н. Изучение приповерхностной структуры метаморфических толщ георадарным методом (Северное Приладожье) / П. Н. Александров, Ю. А. Морозов, А. Л. Кулаковский [и др.] // Геофизические исследования. 2020. T. 21, № 1. С. 5-23.

14. Глубинный георадар: принципы и применение / А. В. Попов, И. В. Прокопович, Д. Е. Едемский [и др.] // Электромагнитные волны и электронные системы. 2018. Т. 23, № 4. С. 28-36. 
15. Deep penetration subsurface radar: Hardware, results, interpretation / A. I. Berkut, D. E. Edemsky, V. V. Kopeikin [et al.] // 9th Intern. Symp. on Advanced Ground Penetration Radar (IWAGPR), PS-2, 3 25. Edinbourgh, UK, 2017.

16. Оценка состояния массива георадиолокационным зондированием для совершенствования буровзрывных работ в условиях криолитозоны / С. П. Николаев, Б. Н. Заровняев, Л. Л. Федорова, Г. А. Куляндин // Горн. журн. 2018. № 12. С. 9-13.

17. Калашник, А. И. Георадарное исследование геолого-структурного строения рабочего уступа карьера / А. И. Калашник, А. Ю. Дьяков // Известия вузов. Горн. журн. 2015. № 6. С. 73-78.

18. Калашник, А. И. Оценка нарушенности скальных пород георадарным зондированием с использованием водонасыщения для контрастности / А. И. Калашник, А. Ю. Дьяков // Вестник МГТУ. 2019. Т. 22, № 1. С. 129-137.

19. Андрианов, С. В. Мониторинг состояния заобделочного пространства горных выработок методом георадиолокации / С. В. Андрианов // Горн. информ.аналит. бюл. 2019. № 5. С. 124-132.

20. Мусалев, Д. Н. Опыт георадиолокационных исследований при научнотехническом сопровождении горных работ на Старобинском месторождении калийных солей / Д. Н. Мусалев, Н. Н. Прохоров, А. М. Клабук // Горн. журн. 2018. № 8. С. 42-47.

21. Оценка скорости распространения электромагнитных волн в солях Верхнекамского месторождения солей / А. А. Жуков, А. М. Пригара, И. Ю. Пушкарева, Р. И. Царев // Инженерные изыскания. 2017. Т. 3. С. 28-33.

22. Федорова, Л. Л. Опыт применения метода георадиолокации при эксплуатационной разведке россыпных месторождений золота Якутии / Л. Л. Федорова, Г. А. Куляндин // Успехи современного естествознания. 2018. № 11. С. 160-165.

23. Федорова, Л. Л. Георадиолокационная оценка влажности горных пород / Л. Л. Федорова, Г. А. Куляндин, К. О. Соколов // Горн. информ.-аналит. бюл. (научно-технический журнал). 2017. № 8. С. 152-158.

24. Саввин, Д. В. Опыт георадиолокационных исследований при инженерногеологических изысканиях в центральной Якутии / Д. В. Саввин, Л. Л. Федорова, Е. Э. Соловьев // Инженерные изыскания. 2018. Т. 12, № 7-8. С. 92-100.

25. Соколов, K. O. Вейвлет-критерий для анализа данных георадиолокации мерзлого горного массива / К. О. Соколов // Горн. информ.-аналит. бюл. (научно-технический журнал). 2014. № 11. С. 262-266.

26. Федорова, Л. Л. Решение задач обработки и интерпретации георадиолокационных данных на основе вейвлет-анализа / Л. Л. Федорова, К. О. Соколов // Горн. информ.-аналит. бюл. 2008. № 8. С. 153-158.

27. Соколов, K. О. Возможности георадиолокации при исследовании разрывных нарушений на месторождениях полезных ископаемых криолитозоны / К. О. Соколов, П. А. Попков, Н. Д. Прудецкий // Горн. информ.-аналит. бюл. 2013. № 3. C. 351-355.

28. Федорова, Л. Л. Опыт применения метода георадиолокации при эксплуатационной разведке россыпных месторождений золота Якутии / Л. Л. Федорова, Г. А. Куляндин // Успехи современного естествознания. 2018. № 11. С. 160-165.

29. Соколов, $K$. O. Выявление границ продуктивного слоя алмазоносной россыпи частотно-временным анализом данных георадиолокации мерзлого горного 
массива / К. О. Соколов, Л. Л. Федорова, А. В. Омельяненко // Горн. информ.аналит. бюл. 2009. № 7. С. 147-151.

30. Никулин, Н. Ю. Комплексный геолого-геофизический мониторинг состояния и свойств грунтового основания горнотехнического сооружения / Н. Ю. Никулин, С. М. Простов, О. В. Герасимов // Вестник Кузбасского государственного технического университета. 2012. № 3 (91). С. 3-8.

31. Простов, С. М. Георадиолокационный мониторинг при укреплении грунтовых оснований горнотехнических сооружений в Кузбассе / С. М. Простов, Н. Ю. Никулин // Вестник Кузбасского государственного технического университета. 2015. № 5 (111). С. 11-19.

32. Никулин, Н. Ю. Георадиолокационный мониторинг при изучении свойств закрепленного массива / Н. Ю. Никулин // Вестник Кузбасского государственного технического университета. 2013. № 3 (97). С. 7-11.

33. Опыт работы. Компания ВНИИСМИ. Режим доступа: http://www.georadar.ru/works.php.

34. Возможности георадарного метода при обследовании подпорных стен и ограждающих конструкций / Н. Е. Фоменко, Д. А. Гапонов, В. В. Капустин [и др.] // Известия Томского политехнического университета. Инжиниринг георесурсов. 2017. Т. 328, № 3. С. 37-45.

35. Подповерхностная радиолокация / М. И. Финкельштейн, В. И. Карпухин, В. А. Кутев, В. Н. Метелкин. Москва : Радио и Связь, 1994. 216 с.

36. Владов, М. Л. Введение в георадиолокацию / М. Л. Владов, А. В. Старовойтов. Москва : Изд-во МГУ, 2005. 153 с.

37. Владов, М. Л. Георадиолокационные исследования верхней части разреза / М. Л. Владов, А. В. Старовойтов. Москва : Изд-во МГУ, 2002. 91 с.

38. Владов, М. Л. Георадиолокация. От физических основ до перспективных направлений / М. Л. Владов, М. С. Судакова. Москва : ГЕОС, 2017. 240 с.

39. Старовойтов, A. B. Интерпретация георадиолокационных данных / А. В. Старовойтов. Москва : Изд-во МГУ, 2008. 192 с.

40. Руководство по эксплуатации «Георадары серии ЛОЗА» / ООО ВНИИСМИ. 2011.

41. Атлас физических свойств минералов и пород Хибинских месторождений / И. А. Турчанинов, М. П. Воларович, А. Т. Бондаренко [и др.]. Ленинград : Наука, $1975.71 \mathrm{c}$.

42. Мельников, Н. Н. Создание многоуровневой системы геодинамического мониторинга горнотехнических и нефтегазовых объектов западной части российского сектора Арктики / Н. Н. Мельников, А. И. Калашник // Арктика: экология и экономика. 2015. № 3 (19). С. 66-75.

43. Калашник, А. И. Исследования георадарами структуры и текущего состояния горных пород, слагающих уступы основного карьера Ковдорского ГОКа / А. И. Калашник, Д. В. Запорожец, А. Ю. Дьяков [и др.] // Горн. журн. 2014. № 4. C. 60-64.

44. Калашник, А. И. Оценка нарушенности скальных пород уступа карьера электромагнитным зондированием / А. И. Калашник, А. Ю. Дьяков // Горн. информ.-аналит. бюл. Глубокие карьеры : спец. вып. 2015. № 56. С. 230-238. 
45. Topographic migration of $2 \mathrm{D}$ and $3 \mathrm{D}$ ground-penetrating radar data considering variable velocities / N. Allroggen, J. Tronicke, M. Delock, U. Boniger // Near Surface Geophysics. 2015. Vol. 13. P. 253-259.

46. Antonis, G. Modeling ground penetrating radar using GprMax / G. Antonis // Construction and Building Material. 2005. Vol. 19. P. 755-762.

47. Bano, M. Constant dielectric losses of ground-penetrating radar waves / M. Bano // Geophysics. 1996. No. 124. P. 279-288.

48. Bentner, A. Focusing ground penetrating radar images / A. Bentner, W. Moore, M. Antolovich // Progress in Electromagnetics Res. 2011. No. 19. P. 183-195.

49. Tzanis, A. MATGPR: A freeware MATLAB package for the analysis of commonoffset GPR data / A. Tzanis // Geophys. Res. Abstracts. 2006. Vol. 8. P. 09488.

50. Tzanis, $A$. A freeware package for the analysis \& interpretation of common and single offset GPR data / A. Tzanis // Fast Times. 2010. No. 15 (1). P. 17-43.

51. Старовойтов, А. В. Интерпретация данных георадиолокационных наблюдений / А. В. Старовойтов, М. Л. Владов // Разведка и охрана недр. 2001. № 3. С. 11-14.

52. Гензе, Д. А. Диэлектрическая проницаемость грунтов нарушенной структуры / Д. А. Гензе, А. Н. Шуваев // Вестник ТГАСУ. 2011. № 1. С. 200-206.

53. Низаметдинов, H. Ф. Наземное лазерное сканирование в геодезии / Н. Ф. Низаметдинов, Р. Ф. Низаметдинов // Маркшейдерский вестник. 2013. № 3. C. 24-26.

54. Бастраков, Ю. Г. Съемка единых объектов недвижимости лазерным сканером / Ю. Г. Бастраков, Д. А. Ковалев, Е. С. Саламонов // Геодезия и картография. 2013. № 11. С. 51-54.

55. Лукичёв, С. В. Автоматизированные инструменты инженерного обеспечения горных работ в системе MINEFRAME / C. В. Лукичёв, О. В. Наговицын // Горн. информ.-аналит. бюл. 2013. № 7. С. 184-192.

56. Лукичёв, С. В. Геоинформационные методы анализа результатов геодезических и геофизических исследований при оценке результатов карьерных массовых взрывов / С. В. Лукичёв, А. Ю. Дьяков, А. С. Шишкин // Проблемы недропользования. 2016. № 3 (10). С. 89-95.

57. Исследования горнотехнических конструкций карьера георадарными технологиями / А. И. Калашник, С. В. Казачков, В. А. Сохарев [и др.] // Вестник КНЦ РАН. 2012. № 2. С. 58-64.

58. Выявление дислокаций в скальных горнотехнических конструкциях / А. И. Калашник, С. В. Казачков, В. А. Сохарев [и др.] // Вестник МГТУ. 2013. T. 16, № 1. С. 93-97.

59. Калашник, А. И. Георадарное исследование геолого-структурного строения рабочего уступа карьера в целях оптимизации параметров проведения буровзрывных работ / А. И. Калашник, А. Ю. Дьяков // Вестник КНЦ РАН. 2015. № 3. С. 48-53.

60. Калашник, А. И. Исследования ограждающего насыпного гидротехнического сооружения как прототипа дамбы хвостохранилища горно-обогатительного предприятия / А. И. Калашник, Н. А. Калашник // Вестник КНЦ РАН. 2013. № 1. C. 27-30.

61. Дьяков, А. Ю. Георадар как инструмент для решения горных задач / А. Ю. Дьяков // Междунар. журн. гуманитарных и естественных наук. 2019. № 12-1 (39). C. $64-68$. 
62. Калашник, А. И. Критерии оценки состояния рабочих уступов карьера «Железный» на основе исследования их георадиолокацией / А. И. Калашник, А. Ю. Дьяков // Мониторинг природных и техногенных процессов при ведении горных работ : сб. докл. Всерос. науч.-техн. конф. с междунар. участием, 24-27 сентября 2013 г. Апатиты ; СПб., 2013. С. 255-261.

63. Карпенко, Н. П. Гидрогеология и основы геологии : учебное пособие / Н. П. Карпенко, И. М. Ломакин, В. С. Дроздов. Москва : Инфра-М, 2018. 328 с.

64. Кожназаров, А. Д. Гидрогеология : учебник / А. Д. Кожназаров, И. С. Рачков. Алматы : Ценные бумаги, 2015. 312 с.

65. Всеволожский, В. А. Основы гидрогеологии : учебник / В. А. Всеволожский. 2-е изд. перераб. и доп. Москва : Изд-во МГУ, 2007. 448 с.

66. Комплексная многоуровневая система геомониторинга природно-технических объектов горнодобывающих комплексов / Н. Н. Мельников, А. И. Калашник, Н. А. Калашник [и др.] // Физико-технические проблемы разработки полезных ископаемых. 2018. № 4. С. 3-10.

67. Применение современных методов для комплексных исследований состояния гидротехнических сооружений региона Баренцева моря / Н. Н. Мельников, А. И. Калашник, Н. А. Калашник [и др.] // Вестник МГТУ. 2017. T. 20, № 1-1. С. 13-20.

68. Monitoring water transfers in limestone building materials with water retention curve and Ground Penetrating Radar: A comparative study / Xiaoting Xiao, Borui Guan, Amine Ihamouten [et al.] // NDT \& E International. 2018. Vol. 100, December. P. 31-39.

69. Волковиикий, М. Б. Георадиолокационный метод диагностики земляного полотна / М. Б. Волковицкий, А. Г. Круглый // Вестник ВНИИ железнодорожного транспорта. 1996. № 6. С. 35-40.

70. Боярский, Д. А. Влияние связанной воды на диэлектрическую проницаемость влажных и мерзлых почв / Д. А. Боярский, В. В. Тихонов. Москва : ИКИ РАН, 2003. $48 \mathrm{c}$.

71. Опытно-фильтрационные работы / В. М. Шестаков, Д. Н. Башкатов, И. С. Пашковский [и др.]. Москва : Недра, 1974. 204 с.

72. Геология : учебное пособие / С. С. Бондаренко, Г. И. Потапов, С. Л. Афанасьев, В. Н. Лукин. Москва : МГОУ, 2004. 142 с.

73. Савич, А. И. Исследование упругих и деформационных свойств горных пород сейсмоакустическими методами / А. И. Савич, В. Г. Ященко. Москва : Недра, 1979. $215 \mathrm{c}$.

74. Рыббин, В. В. Определение параметров напряженного состояния приконтурного массива пород на карьерах Кольского полуострова / В. В. Рыбин, А. А. Козырев, И. В. Данилов // Горн. информ.-аналит. бюл. 2009. № 10. С. 402-405.

75. Исследование напряженно-деформированного состояния массива пород численными методами на основе данных натурных измерений в окрестности крупной карьерной выемки / А. А. Козырев, И. Э. Семенова, В. В. Рыбин, И. М. Аветисян // Горн. информ.-аналит. бюл. 2011. № 11. С. 78-89.

76. Калашник, А. И. Комплексные исследования и мониторинг хвостохранилищ горнопромышленных предприятий Кольского региона / А. И. Калашник // Горн. журн. 2020. № 9. С. 101-106.

77. Виттке, В. Механика скальных пород / В. Виттке. Москва : Недра, 1990. 439 с. 
78. Мусхелишвили, Н. И. Некоторые основные задачи математической теории упругости / Н. И. Мусхелишвили. Москва : Наука, 1966. 707 с.

79. Тимошенко, С. П. Теория упругости : перевод с английского / С. П. Тимошенко, Дж. Гудьер. Москва : Наука, 1975. 576 с.

80. О безопасности гидротехнических сооружений : федер. закон № 117-Ф3 : принят Госдумой 23 июня 1997 г. // Законодательство Российской Федерации : сборник основных федеральных законов : [сайт]. Режим доступа: https://fzrf.su/zakon/o-bezopasnosti-gidrotekhnicheskih-sooruzhenij-117-fz/.

81. Правила безопасности гидротехнических сооружений накопителей жидких промышленных отходов ПБ 03-438-02.

82. Свод правил. Гидротехнические сооружения. СП 58.13330.2012.

83. Мониторинг состояния ограждающей дамбы в зоне отработки техногенного месторождения Ковдорского ГОКа / А. А. Данилкин, А. И. Калашник, Д. В. Запорожец, Д. А. Максимов // Горн. информ.-аналит. бюл. 2014. № 7. С. 344-351.

84. Калашник, А. И. Идентификация фильтрационно-деформационных процессов в теле ограждающей дамбы хвостохранилища / А. И. Калашник, Д. В. Запорожец, Н. А. Калашник // Вестник КНЦ РАН. 2013. № 2. С. 13-16.

85. Научно-технический прогресс на горнорудных предприятиях Заполярья / Н. Н. Мельников, П. А. Усачев, Ю. В. Демидов [и др.]. Ленинград : Наука, 1988. $239 \mathrm{c}$.

86. Саввин, Д. В. Результаты экспериментальных исследований криогенного состояния горных пород методом георадиолокации в условиях открытой разработки месторождений криолитозоны / Д. В. Саввин, А. В. Омельяненко, Л. Л. Федорова, М. Р. Никифорова // Горн. информ.-аналит. бюл. 2011. № 8. C. $300-305$.

87. Омельяненко, A. B. Геофизическое картирование подповерхностных геологических структур криолитозоны / А. В. Омельяненко, Д. В. Саввин, Н. Д. Прудецкий // Горн. информ.-аналит. бюл. : [отд. вып.: Дальний Восток - 1]. 2009. № 4. C. 106-114.

88. Francke, $J$. A review of selected ground penetrating radar applications to mineral resource evaluations / J. Francke // J. Applied Geophys. 2012. Vol. 81. P. 29-37.

89. Lai, $W$. Using ground penetrating radar and time-frequency analysis to characterize construction materials / W. Lai, T. Kind, H. Wiggenhauser // NDT and E International. 2011. Vol. 44. P. 111-120.

90. Mapping shallow soil moisture profiles at the field scale using full-waveform / J. Minet, A. Wahyudi, P. Bogaert [et al.] // Geoderma. 2011. Vol. 161. P. 225-237.

91. Калашник, А. И. Исследование взаимосвязи параметров электромагнитного зондирования и напряженного состояния пород уступов карьера / А. И. Калашник, А. Ю. Дьяков // Известия вузов. Горн. журн. 2013. № 8. C. $58-63$.

92. Пути стабилизации и развития горнопромышленного комплекса Мурманской области / А. Д. Маслов, Н. Н. Мельников, А. И. Калашник [и др.] // Горн. журн. 1998. № 4. С. 6-10.

93. Калашник, А. И. Информационные технологии в задачах мониторинга гидротехнических сооружений горнодобывающих предприятий подповерхностным георадиолокационным зондированием / А. И. Калашник, А. Ю. Дьяков // 
Горн. информ.-аналит. бюл. (научно-технический журнал). 2017. № S23. C. $283-291$.

94. Максимов, Д. А. О недостаточности существующих методов повышения фильтрационной устойчивости насыпных гидротехнических сооружений горного профиля / Д. А. Максимов // Горн. информ.-аналит. бюл. (научнотехнический журнал). 2018. № 7. С. 33-39.

95. Максимов, Д. А. Индикаторы наличия в теле насыпного гидротехнического сооружения локальных нарушений фильтрационной устойчивости / Д. А. Максимов // Проблемы недропользования. 2018. № 2 (17). С. 98-105.

96. Калашник, А. И. Комплексирование георадарного и сейсмического зондирования дамбы хвостохранилища / А. И. Калашник, А. Ю. Дьяков, Н. Н. Абрамов // Известия вузов. Горн. журн. 2018. № 4. С. 104-111.

97. Абрамов, Н. Н. Идентификация водонасыщенных зон в ограждающем грунтовом гидротехническом / Н. Н. Абрамов, А. Ю. Дьяков, А. И. Калашник // Идентификация водонасыщенных зон в ограждающем грунтовом гидротехническом сооружении синхронным электромагнитным и сейсмическим зондированием // Гидротехническое строительство. 2019. № 2. С. 17-21.

98. Абрамов, Н. Н. Изучение внутренней структуры грунтовых гидротехнических сооружений неразрушающими сейсмическими методами / Н. Н. Абрамов // Гидротехническое строительство. 2007. № 11. С. 44-46.

99. Абрамов, Н. Н. Сейсмотомографическое изучение внутренней структуры дамбы хвостохранилища ОАО «Апатит» / Н. Н. Абрамов, Е. Е. Снежкова // Горн. журн. 2007. № 12. С. 39-42.

100. Боганик, Г. Н. Сейсморазведка / Г. Н. Боганик, И. И. Гурвич. Тверь : АИС, 2006. $744 \mathrm{c}$.

101.Бондарев, В. И. Основы сейсморазведки : учебное пособие для вузов / В. И. Бондарев. Екатеринбург, 2003. 332 с.

102. Абрамов, H. Н. Оценка качества уплотнения грунтовых дамб неразрушающим сейсмографическим методом / Н. Н. Абрамов, Ю. А. Епимахов, Е. В. Кабеев // Вестник КНЦ РАН. 2013. № 2. С. 91-97.

103. Абрамов, H. Н. Геомеханическое сопровождение технологии строительства и эксплуатации гидротехнических грунтовых сооружений / Н. Н. Абрамов, Ю. А. Епимахов, Е. В. Кабеев // Гидротехническое строительство. 2014. № 5. C. $11-15$.

104. Гмурман, B. E. Теория вероятностей и математическая статистика : учебное пособие для вузов / В. Е. Гмурман. Москва : Высш. шк., 2004. 479 с. 

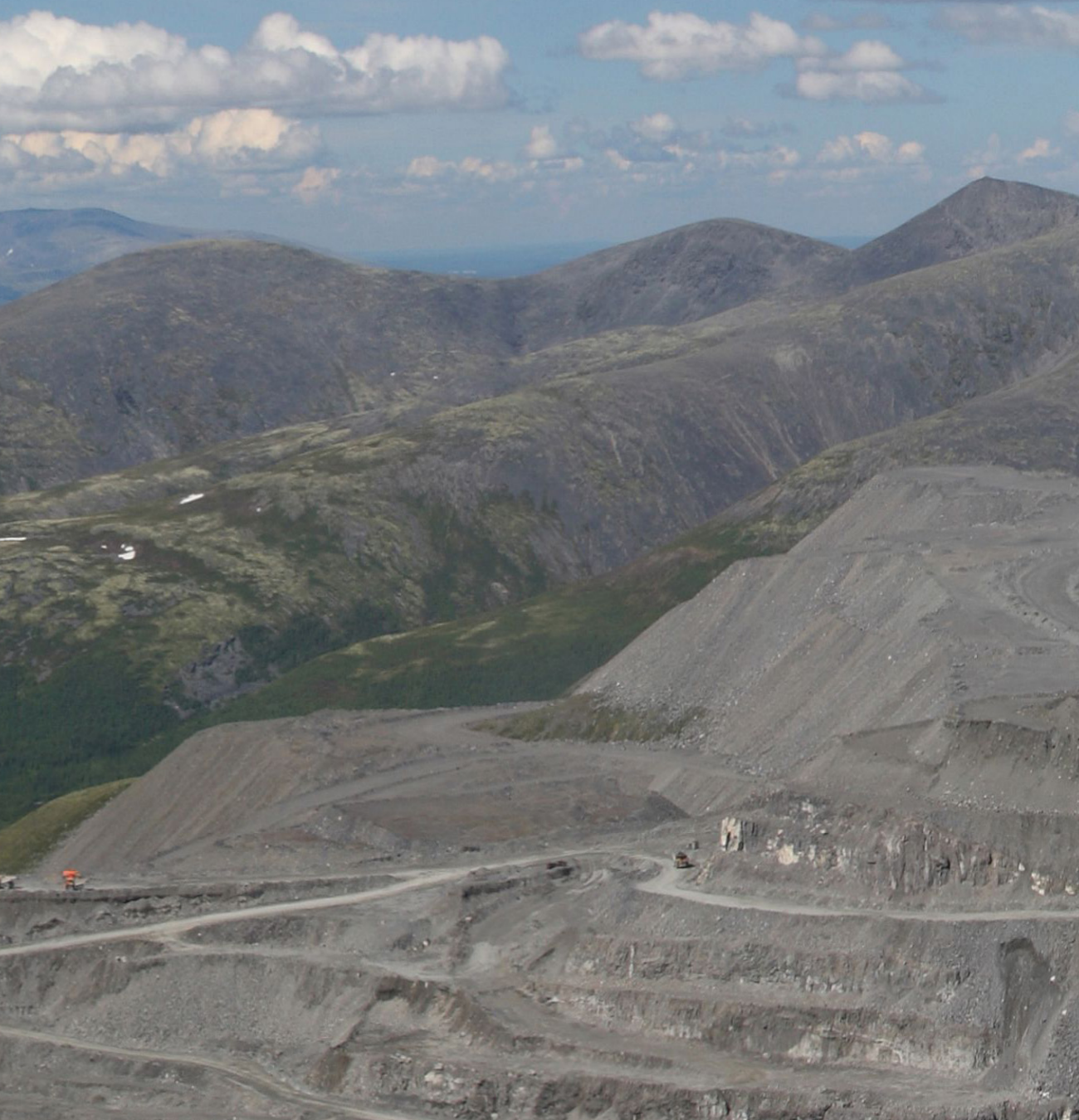

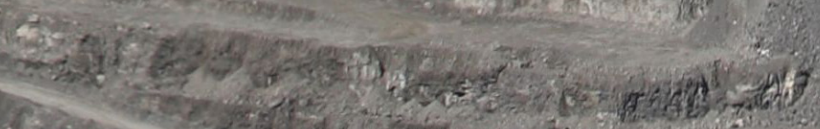

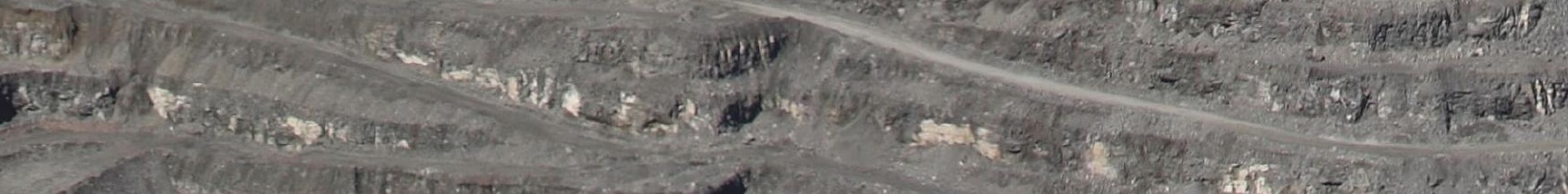

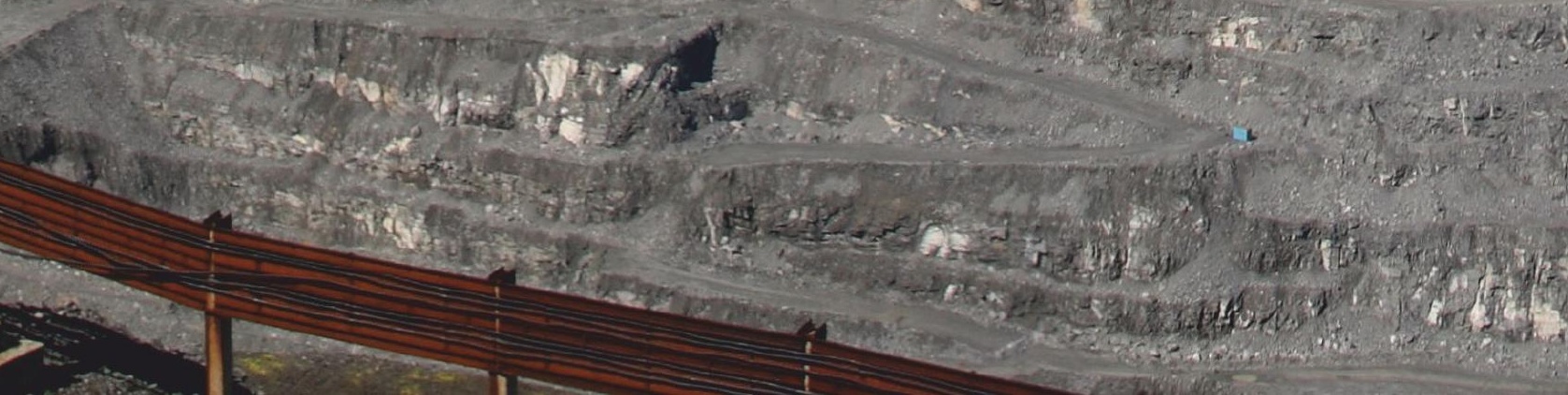

